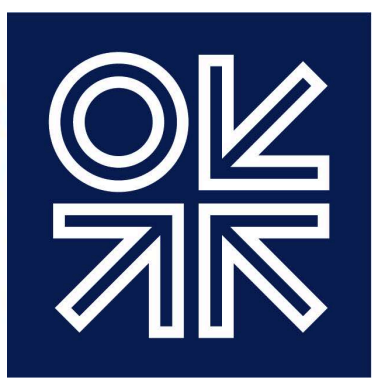

THE OXFORD

INSTITUTE

FOR ENERGY

STUDIES

July 2016

\title{
Sustainable electricity pricing for Tanzania
}

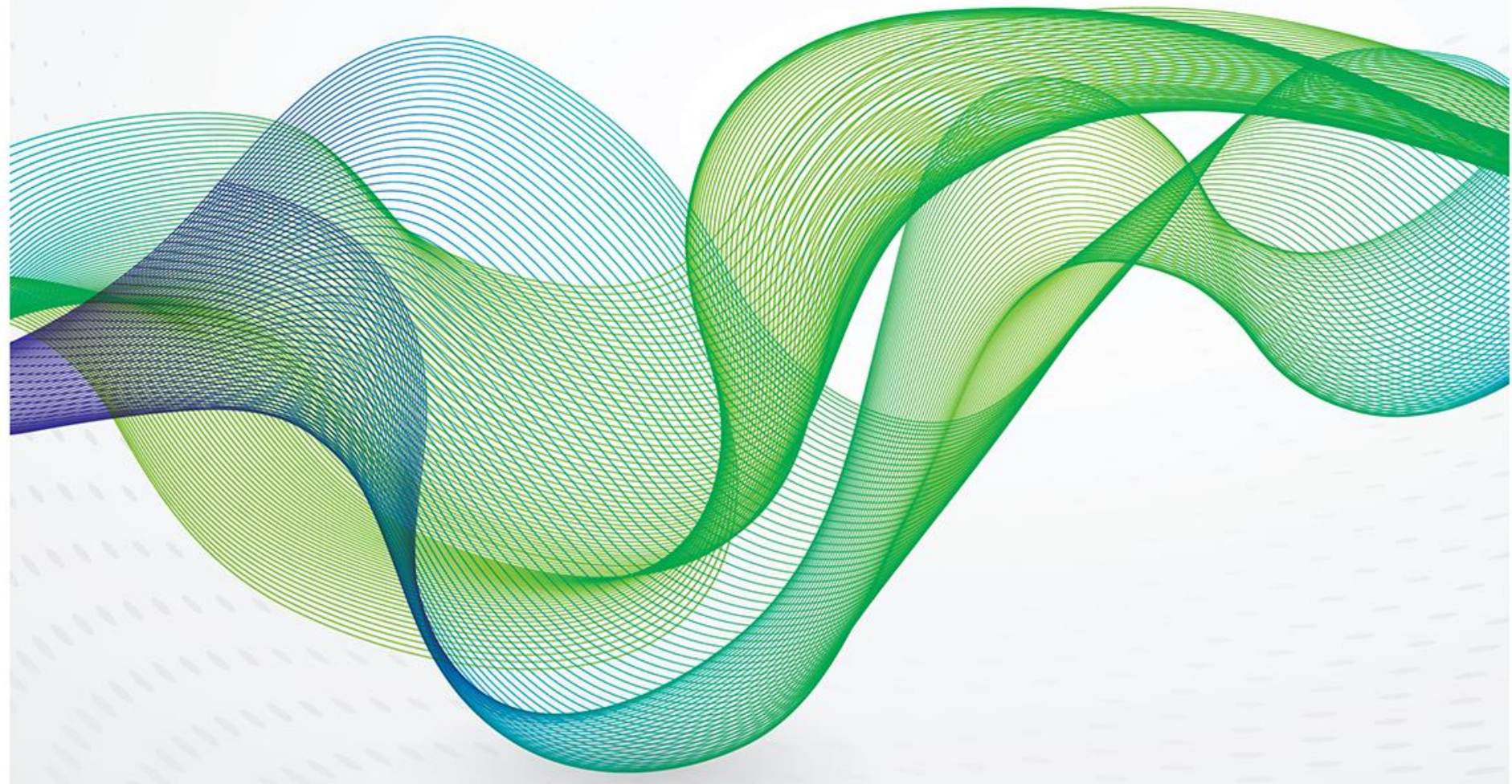



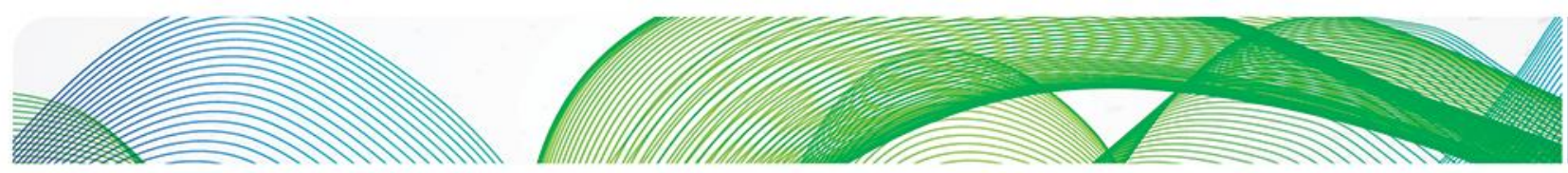

인조

The contents of this paper are the authors' sole responsibility. They do not necessarily represent the views of the Oxford Institute for Energy Studies or any of its members.

\section{Copyright (C) 2016}

\section{Oxford Institute for Energy Studies}

(Registered Charity, No. 286084)

This publication may be reproduced in part for educational or non-profit purposes without special permission from the copyright holder, provided acknowledgment of the source is made. No use of this publication may be made for resale or for any other commercial purpose whatsoever without prior permission in writing from the Oxford Institute for Energy Studies.

ISBN 978-1-78467-061-0 


\section{Contents}

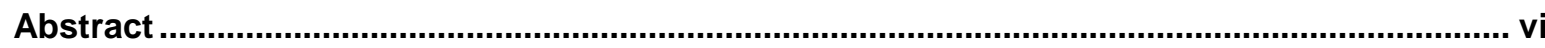

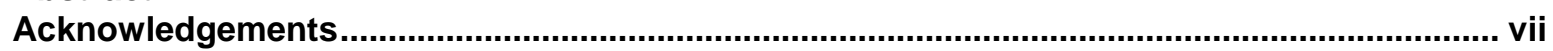

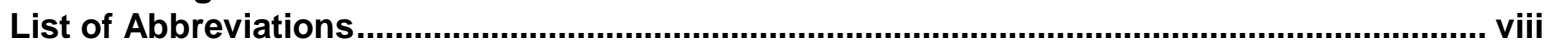

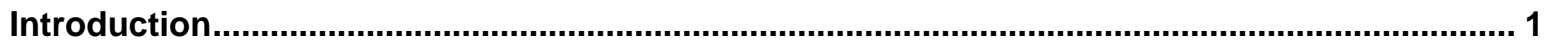

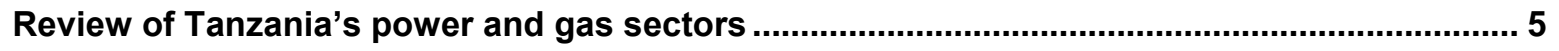

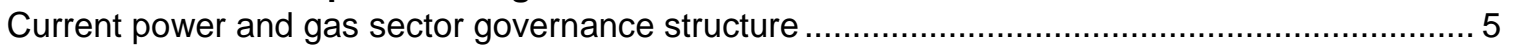

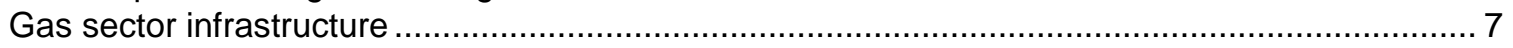

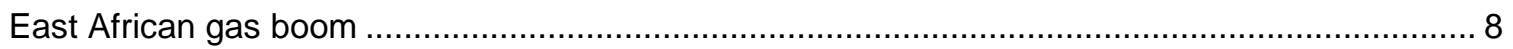

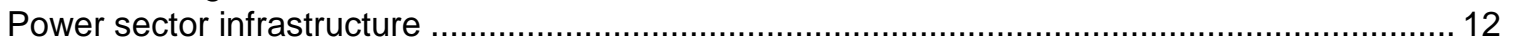

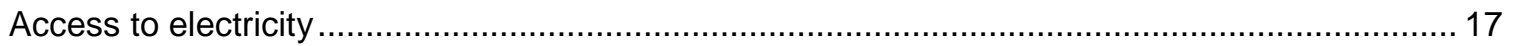

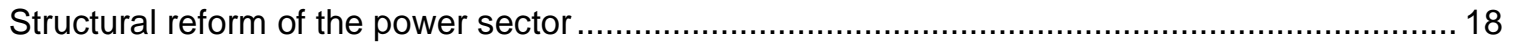

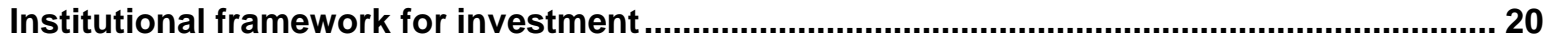

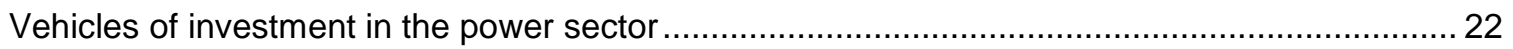

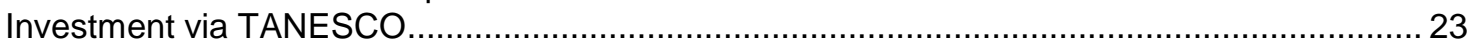

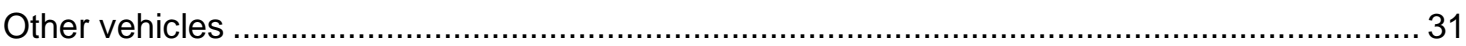

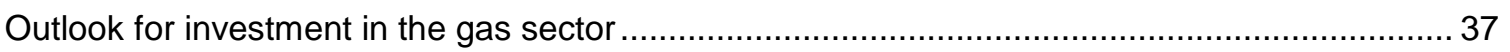

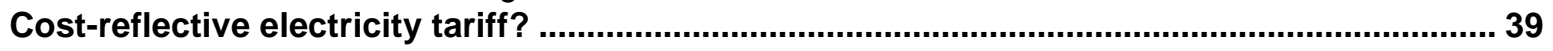

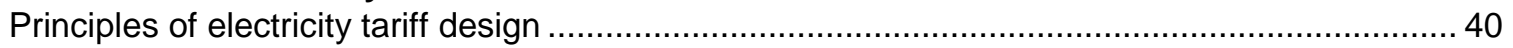

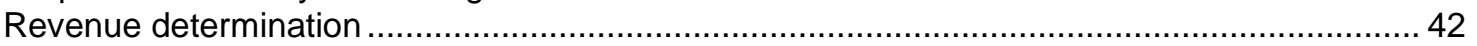

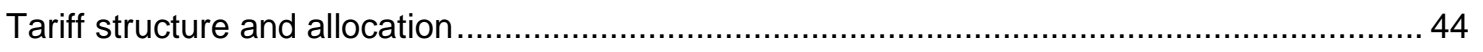

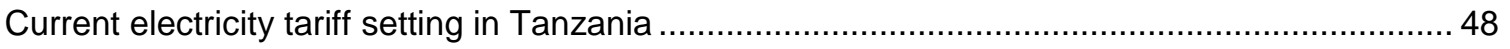

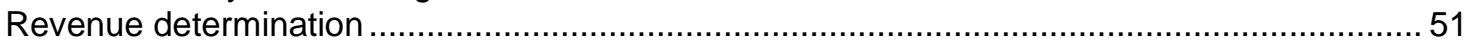

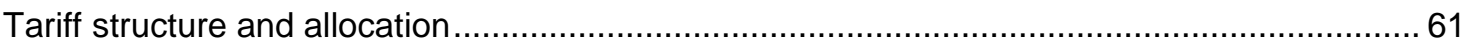

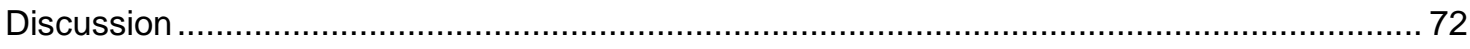

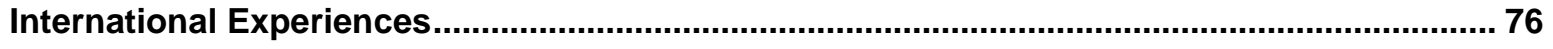

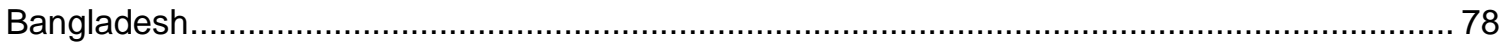

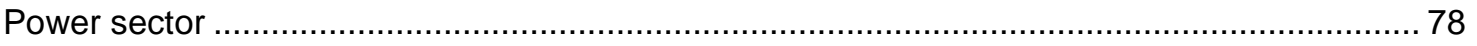

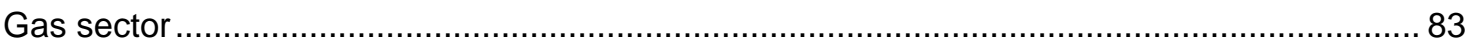

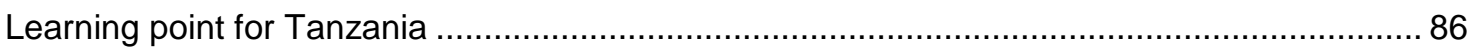

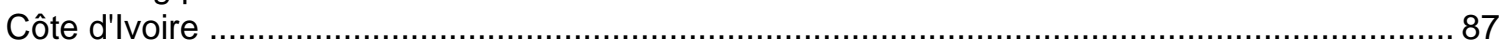

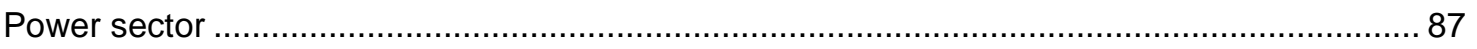

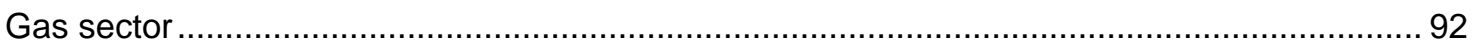

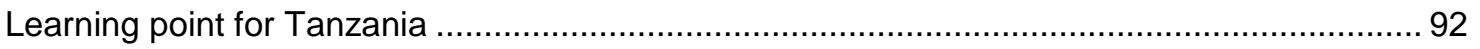

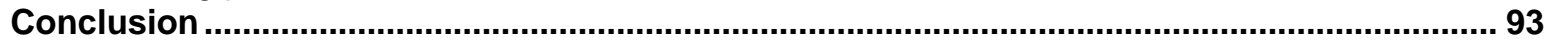

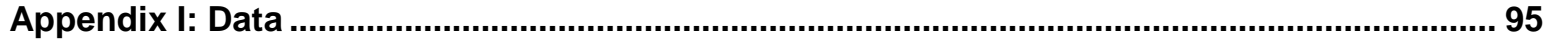

Appendix II: Assumptions used in the comparison of TANESCO proposal with AF-Mercados

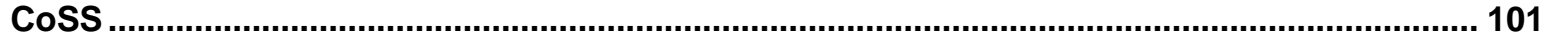

Appendix III: Assumptions to derive revenue requirement based on tariff levels ................ 102

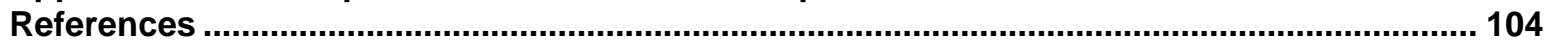



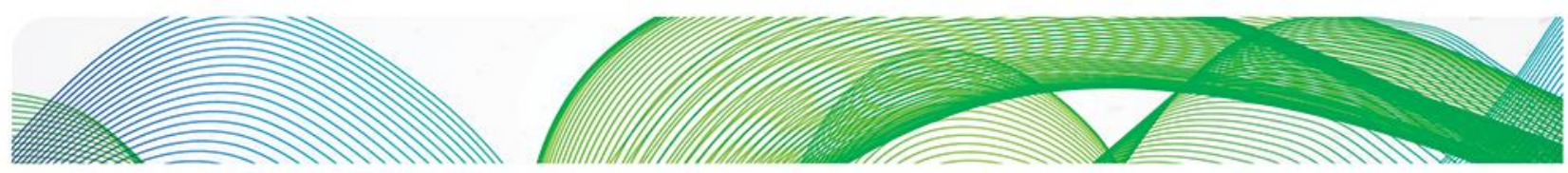

\section{Figures}

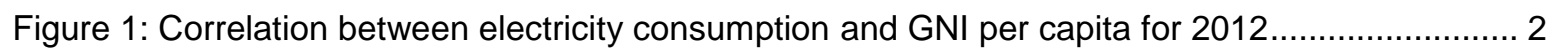

Figure 2: Overall energy use and electricity consumption for world countries in 2012 ..................... 3

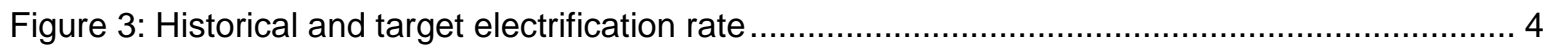

Figure 4: Existing responsibilities of Tanzanian public institutions in the power and gas sectors ...... 6

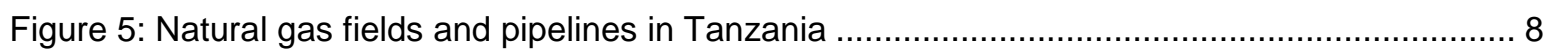

Figure 6: Countries with highest proven gas reserves ........................................................ 10

Figure 7: Recent Tanzania offshore natural gas discoveries ................................................ 11

Figure 8: The Tanzania transmission grid ........................................................................... 13

Figure 9: Installed generation capacity in Tanzania by ownership, generation type and grid

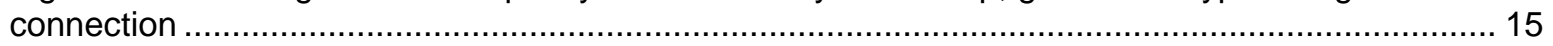

Figure 10: Breakdown of Tanzania's generation capacity expansion plan .................................. 16

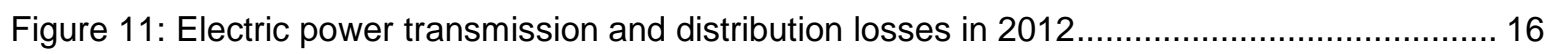

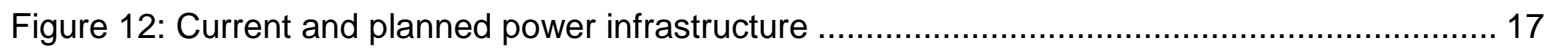

Figure 13: Extrapolation of electricity consumption trend in Tanzania......................................... 18

Figure 14: Current structure of Tanzania's gas and power sectors ........................................... 20

Figure 15: Desired structure of Tanzania's gas and power sectors ............................................ 21

Figure 16: Generation mix of historical and planned installed capacity in 2013 ............................ 22

Figure 17: Modality of historical and planned installed capacity in 2013 .................................... 24

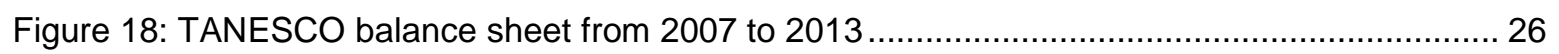

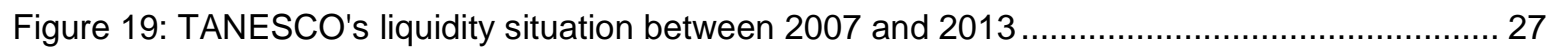

Figure 20: Comparison of TANESCO payable and receivable ..................................................... 28

Figure 21: TANESCO Income statement for 2013 ................................................................. 29

Figure 22: Breakdown of TANESCO cost of sales and revenue during $2007-2013 \ldots \ldots \ldots \ldots \ldots \ldots . . . . . . . . . .30$

Figure 23: TANESCO net change in cash between 2007 and 2013 ......................................... 31

Figure 24: The value of one Tanzanian shilling in US cent...................................................... 31

Figure 25: Evolution of TANESCO revenue and revenue requirement ........................................ 41

Figure 26: The accounting approach for cost allocation .......................................................... 47

Figure 27: The marginal cost approach for cost allocation ......................................................... 48

Figure 28: Revenue surplus and revenue deficit under different LRMC curves ............................ 49

Figure 29: The evolution of historical (2011-12) and forecasted (2013-15) components making up

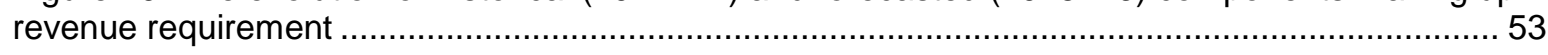

Figure 30: Breakdown of TANESCO forecasted 2013 revenue requirement ............................... 54

Figure 31: Comparison of gross power demand .................................................................. 57

Figure 32: Comparison of generation segment revenue requirement .......................................... 58

Figure 33: Comparison of variable costs of different generating plants ........................................ 59

Figure 34: Comparison of transmission and distribution segment revenue requirement.................60

Figure 35: Comparison of planned loan repayment with expected utility liabilities ........................ 61

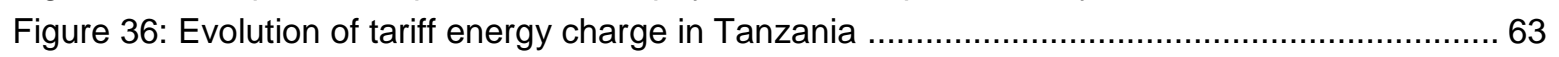

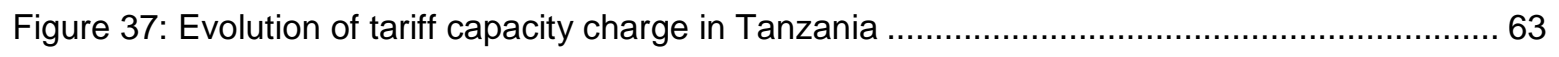



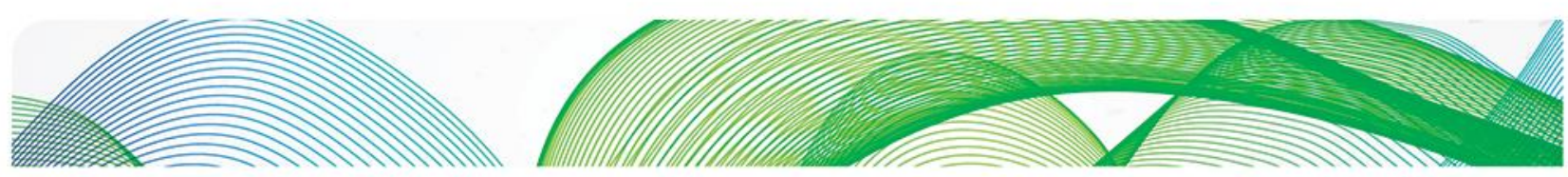

Figure 38: Evolution of tariff service charge in Tanzania 64

Figure 39: Comparison of the estimates for proposed tariff charged to customers and for TANESCO's revenue requirement

Figure 40: Comparison of the estimates for approved tariff charged to customers and for TANESCO's revenue requirement....

Figure 41 Average price of electricity for different categories of customers at load factor $=0.7 \ldots \ldots 67$ Figure 42 Average price of electricity for select categories of customers at load factor $=0.1$ and 0.9 .......

Figure 43: Contribution of different types of charges to total tariff collected. 69

Figure 44: Comparison of customer class contribution to tariff collection and demand................... 70

Figure 45: Comparison of proposed and approved tariff charges to be collected 2013-15 ............ 71

Figure 46: Comparison of customer class contribution to tariff collection under proposed and

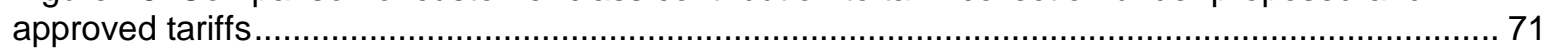

Figure 47: Relative change in the energy charge for various customer classes since 2006 .......... 72

Figure 48: Merit order of Tanzanian installed capacity ............................................................. 75

Figure 49: Electricity consumption vs. electricity produced from natural gas for world countries..... 77

Figure 50: Development of electrification in select regions from 1990 to 2012 .............................. 78

Figure 51: Breakdown of generation capacity in Bangladesh ................................................... 80

Figure 52: Evolution of installed capacity, demand, and peak generation in Bangladesh ................ 83

Figure 53: Historical and forecasted demand for natural gas in Bangladesh ................................ 85

Figure 54: Compound growth rate of gas demand in different sector since 1990 .......................... 86

Figure 55: Breakdown of generation capacity in Côte d'Ivoire..................................................... 89

Figure 56: Electricity generation, consumption, and exports in Côte d'Ivoire between 1980 and

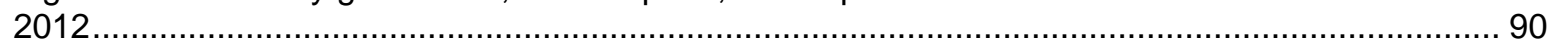

Figure 57: Evolution of revenue requirement and tariff collected in Côte d'Ivoire............................ 92

Figure 58: Evolution of rural electrification measures for Côte d'Ivoire ............................................ 92

Figure 59: Demand forecast for different class of customers .................................................. 103

\section{Tables}

Table 1: Summary of unconstrained electricity demand forecast results..................................... 4

Table 2: Comparison of investment needs in Tanzania's electricity and gas sectors ...................... 23

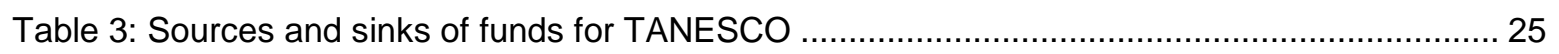

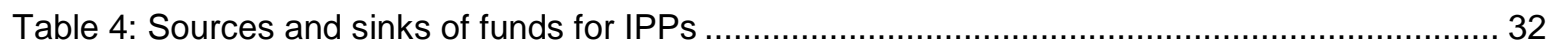

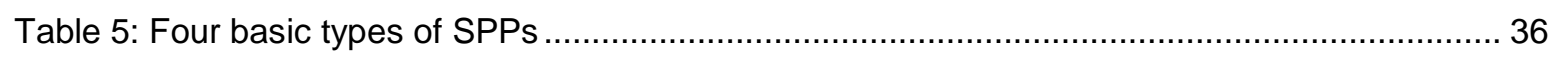

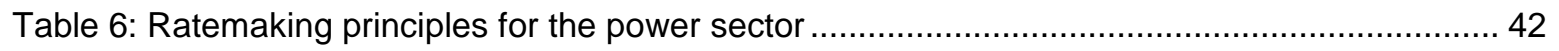

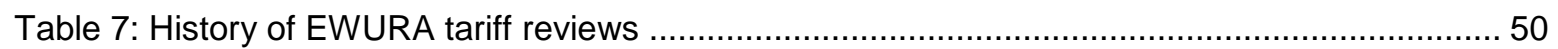

Table 8: Evaluation framework for the tariff setting mechanism in Tanzania .................................. 51

Table 9: Comparison of energy systems of Tanzania, Bangladesh, Nigeria, and Côte d'Ivoire ....... 79

Table 10: Categories of BERC-regulated wholesale and retail tariffs............................................ 82

Table 11: List of historical and planned generation capacity in Tanzania.................................... 96 

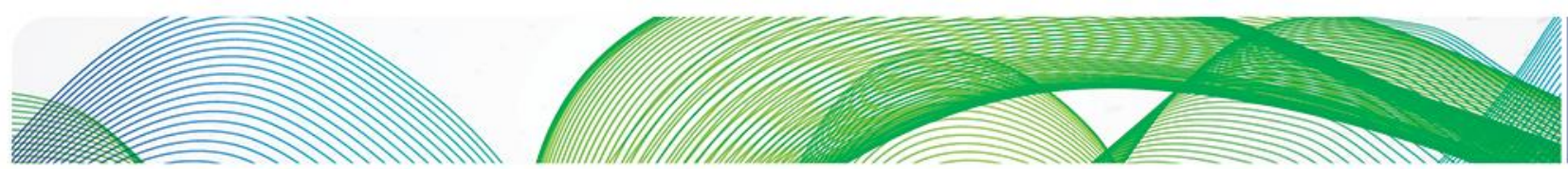

OK

$\nabla \mathbb{R}$

Table 12: List of historical and requested electricity tariffs in Tanzania ..................................... 100

Table 13: Assignment functional segment for TANESCO revenue requirement items ................. 102

Table 14: Tariff collection estimation based on average customer profiles ................................. 104 

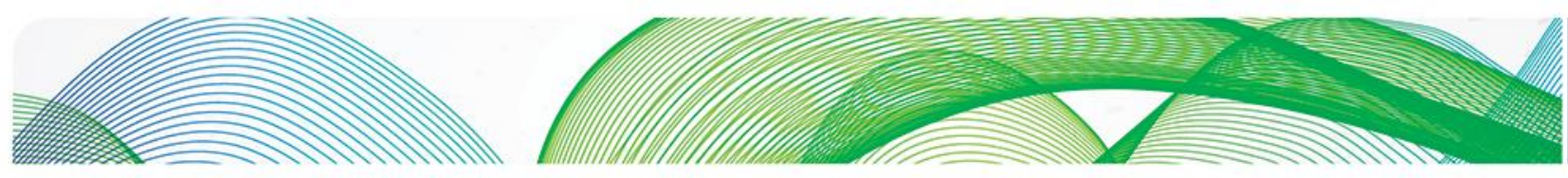

O즌

\title{
Sustainable electricity pricing for Tanzania
}

\author{
Donna Peng \\ OIES-Saudi Aramco fellow, Oxford Institute for Energy Studies \\ Rahmatallah Poudineh \\ Senior research fellow, Oxford Institute for Energy Studies
}

\begin{abstract}
In order to fulfil its aspiration to become a middle-income country, Tanzania is working on improving infrastructure and service delivery in electricity provision, where $\$ 40$ billion investment is needed in the sector to meet rising demand and widening electrification efforts from 2013 to 2035. This paper considers the institutional arrangements for investment in Tanzania's power sector and surveys the track record (and possible bottlenecks) in funnelling investment to the sector, with special attention given to the gas sector, given the power sector's planned reliance upon natural gas as a generation fuel. The paper finds that the financial health of TANESCO is central to all investment vehicles, since it is either directly responsible for investment, or indirectly, as the counter party to the variety of PPAs available with IPPs, EPPs, SPPs, or PPPs. During 2011-13, the financial position of TANESCO was negatively impacted by the increased of its electricity purchases, while the regulated tariff that it charges has not changed. The cost increase is partially attributable to non-favourable hydrology and partially attributable to the depreciation of Tanzanian shilling against the US dollar, in which PPAs are denominated.

Detailed study of the tariff setting methodology in place in Tanzania, as evidenced through its latest tariff review, and evaluation of the ratemaking principles used in the tariff approved in 2013 reveals that the core tension within Tanzania's tariff setting methodology is the trade-off between efficiency, sufficiency, and stability principles. The ex-ante assessment of TANESCO's revenue requirement, a typical incentive-based price cap regulation, is theoretically efficient but not robust: TANESCO's costs of service are subject to important external uncertainties like hydrology, currency depreciation, and global fuel prices. In order to take revenue sufficiency into account, the regulator needs to periodically adjust tariffs based on ex post fuel costs and inflation rates. This diminishes the regulator's ability to maintain tariff stability, which might impact certain classes of customers more than others (lifeline rate customers and domestic industries). The experiences of other nations, namely Bangladesh and Côte d'Ivoire, reveal a potential challenge with regard to power and gas co-development: if non-cost reflective gas tariffs are applied as a regulatory decision, then high gas demand that results from that cannot be indefinitely sustained, since investment in gas supply will not follow suite. The case study of Côte d'Ivoire also reveals a less obvious opportunity: periods of low electricity demand can be leveraged positively through electricity exports, which can positively influence investor interest.
\end{abstract}



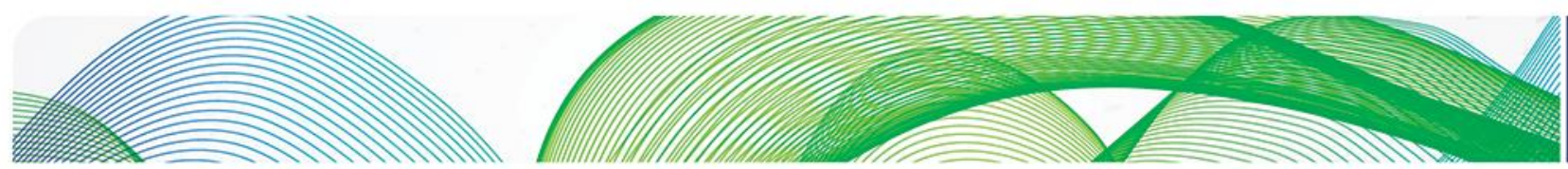

O는

\section{Acknowledgements}

This paper was written for the Tanzania Country Programme of the International Growth Centre (IGC) under Contract No.1-VCE-VTZA-VXXXX-40305. We are grateful for the support provided by Chris Adam and the IGC Country Office in Dar es Salaam especially Ms Anne Laski and Ms Claire Lwehabura. We also acknowledge the comments and assistance from the following institutions and companies: President's Delivery Bureau, TANESCO Utility Company, Rural Energy Agency (REA), Tanzania Petroleum Development Corporation (TPDC), Department for International Development (DfID) office in Tanzania, USAID, Millennium Challenge Corporation (MCC) and Songas and Symbion companies. The opinions expressed in the paper are solely those of the authors. 

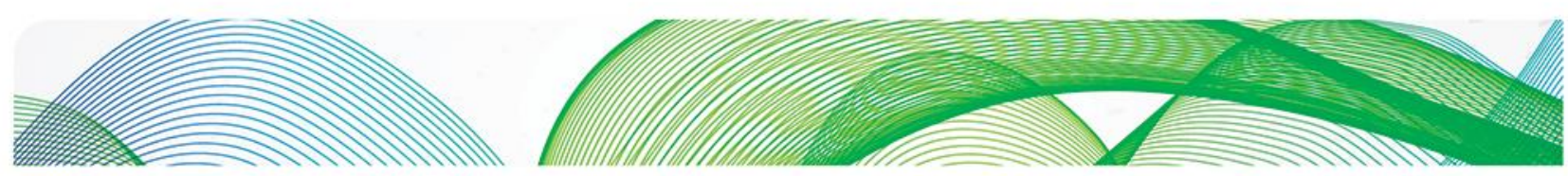

O는

\section{List of Abbreviations}

$\begin{array}{ll}\text { ADB } & \text { Asian Development Bank } \\ \text { AFUDC } & \text { Allowance for Funds Used during Construction } \\ \text { ANARE } & \text { Autorité Nationale de Régulation } \\ \text { BERC } & \text { Bangladesh Energy Regulatory Commission } \\ \text { BPDB } & \text { Bangladesh Power Development Board } \\ \text { BRN } & \text { Big Results Now! } \\ \text { CDC } & \text { Commonwealth Development Corporation } \\ \text { CIE } & \text { Compagnie Ivoirienne d'Electricité } \\ \text { CI-Energies } & \text { Société des Energies de Côte d'Ivoire } \\ \text { CIP } & \text { Capital Investment Plan } \\ \text { CIPREL } & \text { Compagnie Ivoirienne de Production d'Electricité } \\ \text { CoSS } & \text { Cost of Service Study } \\ \text { CPI } & \text { Consumer Price Index } \\ \text { DEG } & \text { German Investment \& Development Company } \\ \text { DESCO } & \text { Dhaka Electric Supply Company } \\ \text { DPDC } & \text { Dhaka Power Distribution Company } \\ \text { EIB } & \text { European Investment Bank } \\ \text { EPP } & \text { Emergency Power Producer } \\ \text { EWURA } & \text { Energy and Water Utility Regulatory Authority } \\ \text { FMO } & \text { Netherlands Development Finance Company } \\ \text { GASCO } & \text { Gas Supply Company } \\ \text { GoT } & \text { Government of Tanzania } \\ \text { GSA } & \text { Gas Supply Agreement } \\ \text { HHV } & \text { Higher heating value } \\ \text { ICC } & \text { International Chamber of Commerce } \\ \text { ICSID } & \text { International Centre for Settlement of Investment Disputes } \\ \text { IDA } & \text { International Development Association } \\ \text { IFC } & \text { International Finance Corporation } \\ \text { IOC } & \text { International Oil Company } \\ \text { IPP } & \text { Independent Power Producer } \\ \text { IPTL } & \text { Independent Power Tanzania Limited } \\ \text { LCOE } & \text { Levelized cost of electricity } \\ \text { LNG } & \text { Liquefied natural gas } \\ \text { LRMC } & \text { Long-run marginal cost } \\ \text { MCM } & \text { Millennium Challenge Corporation } \\ \text { MEM } & \text { Ministry of Energy and Minerals } \\ \text { MPSA } & \text { Model Production Sharing Agreement } \\ & \end{array}$



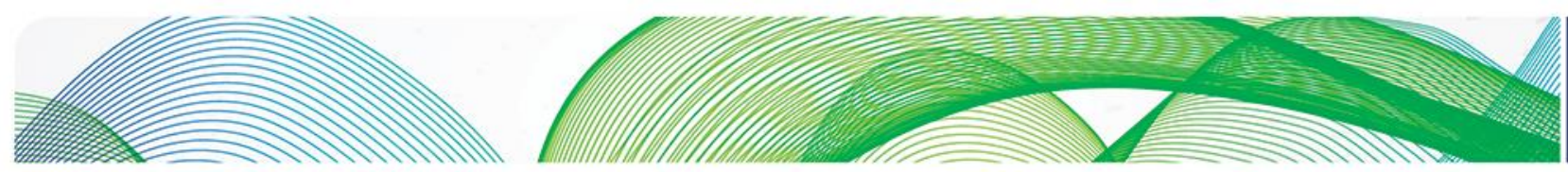

인조

$\begin{array}{ll}\text { mtpa } & \text { million tonnes per annum } \\ \text { NKRA } & \text { National Key Results Area } \\ \text { NOC } & \text { National Oil Company } \\ \text { NORAD } & \text { Norwegian Agency for Development Cooperation } \\ \text { PAE } & \text { Pan Africa Energy } \\ \text { PAP } & \text { Pan African Power } \\ \text { Petrobangla } & \text { Bangladesh Oil, Gas, and Mineral Corporation } \\ \text { PETROCI } & \text { Société Nationale d'Opérations Petrolières de Côte d'Ivoire } \\ \text { PGCB } & \text { Power Grid Company of Bangladesh } \\ \text { PPP } & \text { Public Private Partnership } \\ \text { PSMP } & \text { Power System Master Plan } \\ \text { QRPP } & \text { Quick Rental Power Plant } \\ \text { REA } & \text { Rural Energy Agency } \\ \text { REB } & \text { Rural Electrification Board } \\ \text { SAUR } & \text { Société d'Aménagement Urbain et Rural } \\ \text { SCB-HK } & \text { Standard Chartered Bank Hong Kong } \\ \text { SIDA } & \text { Swedish International Development Cooperation Agency } \\ \text { SIPP } & \text { Small Independent Power Producer } \\ \text { SPP } & \text { Small Power Producer } \\ \text { TANESCO } & \text { Tanzania Electric Supply Company Limited } \\ \text { TDFL } & \text { Tanzania Development Finance Company Limited } \\ \text { TPDC } & \text { Tanzania Petroleum Development Corporation } \\ \text { WACC } & \text { Weighted average cost of capital } \\ & \end{array}$



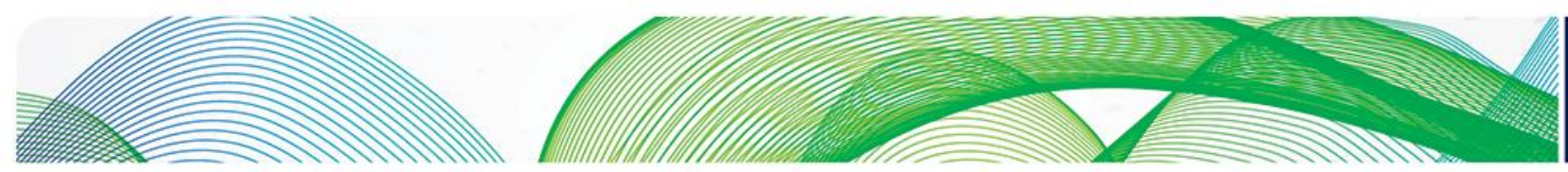

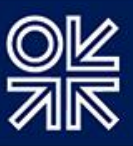

\section{Introduction}

The United Republic of Tanzania, the union of the mainland Tanganyika and the islands of Zanzibar, Pemba, and several smaller islands, is a medium-sized East African country with 50 million inhabitants. The Government of Tanzania (GoT) is working toward the realization of its development targets, articulated as the 'Tanzania Development Vision 2025' through the national development strategy MKUKUTA II, which sets out to reduce income poverty, to improve quality of life and social well-being, and to improve governance and accountability. Transformation of Tanzania's public service delivery is considered necessary to achieve the country's aspirations. Since 2013, the GoT has adopted the Malaysian 'Big, Fast Results' model, a domestic results-driven reform agenda for public sector reforms, known locally as 'Big Results Now!' (BRN) (Janus \& Keijzer, 2015). The BRN focuses on delivering implementation of specific goals within a stipulated delivery timeline. Energy is one of the six National Key Results Areas (NKRA) identified by the GoT, along with agriculture, education, resource mobilization, transport, and water.

One of Tanzania's key development targets is to grow its economy to reach middle-income status by $2025,{ }^{1}$ crossing the Gross National Income (GNI) per capita threshold of $\$ 1,045$ to at least $\$ 3,000$. Access to available energy is considered a pillar for economic and human development. Empirically, consumption of electricity is positively correlated with the GNI per capita achieved by a country. The correlation of electricity consumption with the GNI per capita is especially strong for countries with electricity consumption below $10,000 \mathrm{kWh}$ per capita ${ }^{2}$ (Figure 1 ). The relative level of consumption of electricity in a country is also positively correlated with GNI per capita.

\footnotetext{
${ }^{1}$ The low, middle and, high-income categories are World Bank operational lending categories. A country's status is determined on the basis of its GNI per capita in international dollars using the Atlas method of currency conversion. ${ }^{2}$ At higher electricity consumption, the correlation with GNI per capita decreases; the effect of electricity use has diminishing returns in terms of per capita income beyond a certain threshold.
} 

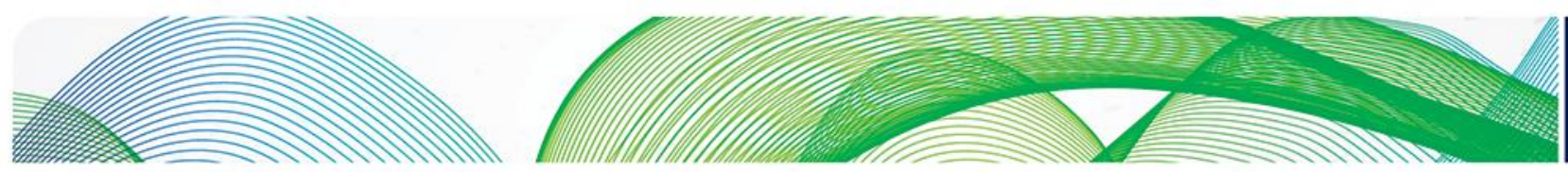

O는

Figure 1: Correlation between electricity consumption and GNI per capita for 2012 (Data source: World Bank)
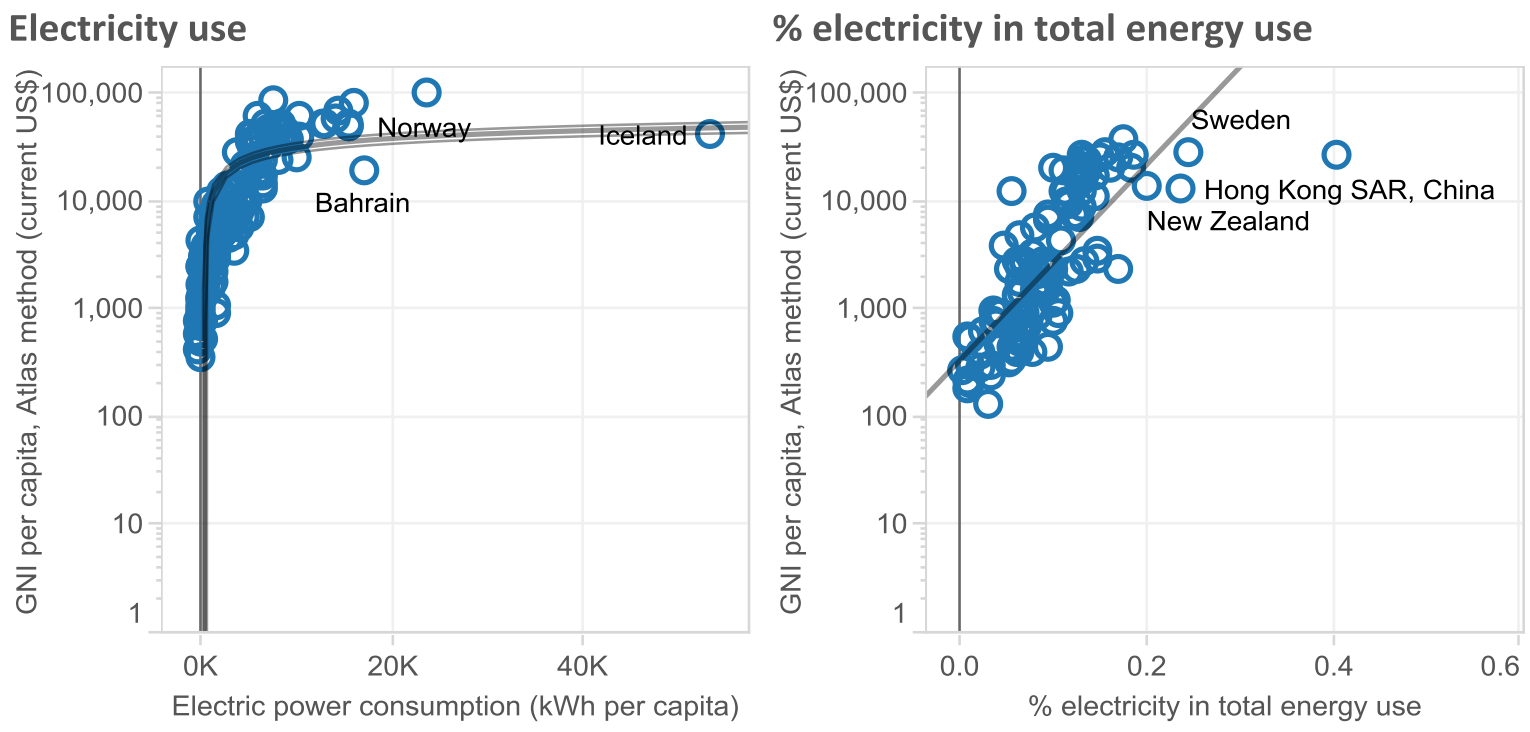

The economic growth of Tanzania has been impressive, with nominal GNI per capita increasing on average by 9.5 percent each year between 2006 and 2014, resulting in a growth from $\$ 450$ to $\$ 930 .^{3}$ Real GDP growth has also proved resilient, averaging 7 per cent over the past decade. In comparison, the per capita electricity consumption in Tanzania grew from $51 \mathrm{kWh}$ to $99 \mathrm{kWh}$ between 2000 and 2012 , at an annualized growth rate of 6 per cent, but it remains low relative to other countries with similar levels of total energy consumption (Figure 2). The other forms of energy consumed by Tanzania are biomass (86.4 per cent), oil products (10.6 per cent), natural gas ( 0.7 per cent), and coal $(0.2$ per cent) (IEA, 2013). The consumption of electricity in the country is constrained by a lack of infrastructure at all segments of the electricity supply chain: generation, transmission, and distribution. If left unresolved, the limited availability of electricity in Tanzania will constrain sustained economic development and prevent the achievement of socio-economic goals.

${ }^{3}$ Part of this is attributable to the GDP rebasing in 2014 (Sy, 2015) 

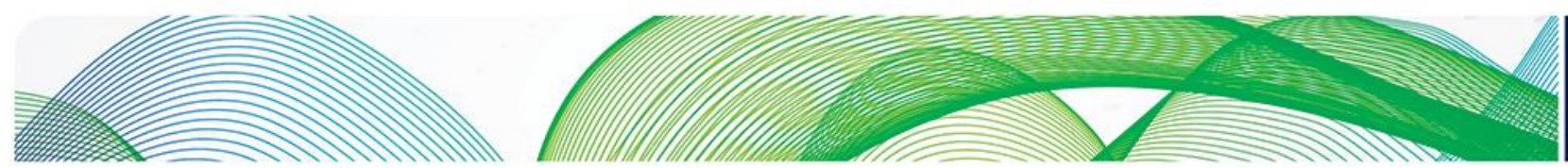

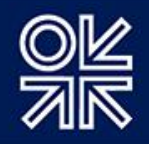

Figure 2: Overall energy use and electricity consumption for world countries in 2012 (Data source: World Bank)

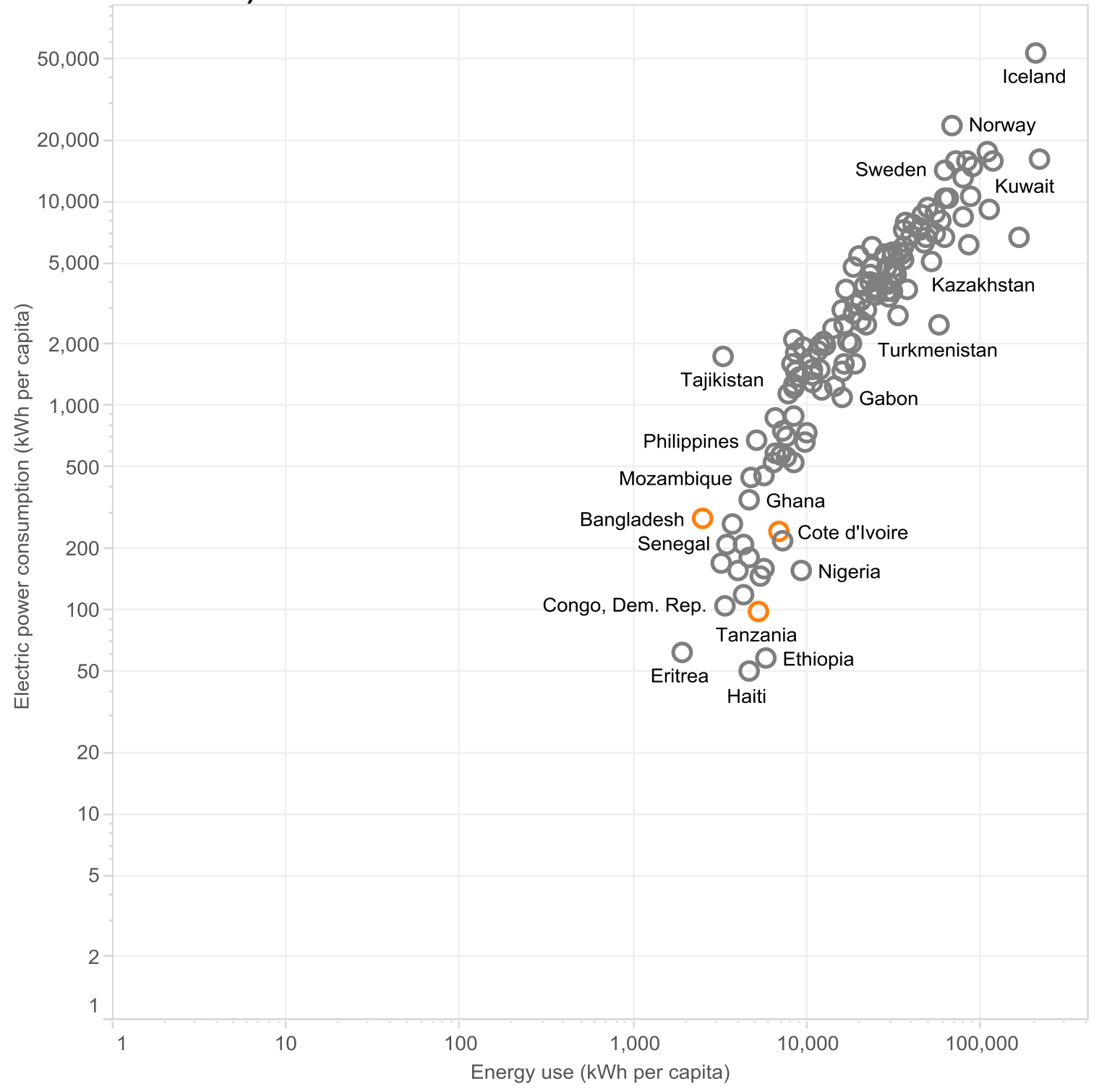

In 2012, the Ministry of Energy and Minerals (MEM) made projections for unconstrained electricity consumption for the period 2010 to 2035, forecasting that per capita electricity consumption would increase five-fold by 2035, to levels on par with Pakistan, Sri Lanka, and Guatemala in 2012 (Table 1). The investment required in generation and transmission to increase installed power generation capacity from 1,466 to $8,960 \mathrm{MW}$ and to increase overall electrification rate from 14 per cent to 72 per cent, is expected to be more than $\$ 40$ billion, the same order of magnitude as Tanzania's GDP ( $\$ 49$ billion in 2014). The BRN Energy lab has set even more ambitious targets for the medium term: for installed capacity to reach 6,000 MW and per capita consumption to reach $490 \mathrm{kWh}$ by 2025 (NKRA Energy, 2015). 

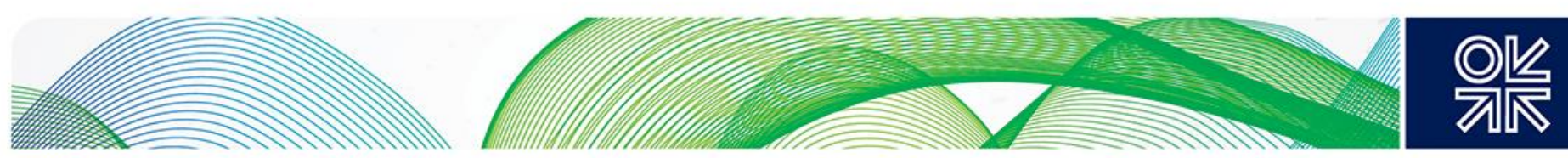

Table 1: Summary of unconstrained electricity demand forecast results (Ministry of Energy and Minerals, 2013a).

\begin{tabular}{llllll}
\hline Year & $\begin{array}{l}\text { Annual } \\
\text { consumption (GWh) }\end{array}$ & $\begin{array}{l}\text { Population } \\
\text { (million) }\end{array}$ & $\begin{array}{l}\text { Electricity consumption } \\
\text { per capita (kWh) }\end{array}$ & $\begin{array}{l}\text { Peak demand } \\
\text { (MW) }\end{array}$ \\
\hline $\mathbf{2 0 1 0}$ & 4,176 & 43.2 & 97 & 1,054 \\
\hline $\mathbf{2 0 2 5}$ & 22,243 & 65.4 & 340 & 4,690 \\
\hline $\mathbf{2 0 3 5}$ & 40,083 & 85.0 & 472 & 7,589 \\
\hline
\end{tabular}

In order to increase the use of electricity, the government has made aggressive electrification targets, hoping to achieve electrification rate to 30 per cent by 2015,55 per cent by 2025 , and at least 75 per cent by 2035 (NKRA Energy, 2015). Although this is less ambitious than the United Nations' goal of universal access to modern energy services by 2030 , it is aligned with estimates from McKinsey, a consultancy: the sub-Saharan Africa is more likely to achieve an electrification rate of 80 per cent by 2040, based on experiences elsewhere such as Tunisia, South Africa, Indonesia, and Brazil (Castellano, Kendall, Nikomarov, \& Swemmer, 2015). The first target has already been reached after important increases in electrification rate in the last two years (Figure 3 ).

Figure 3: Historical and target electrification rate (Data sources: World Bank, IEA, PDB)

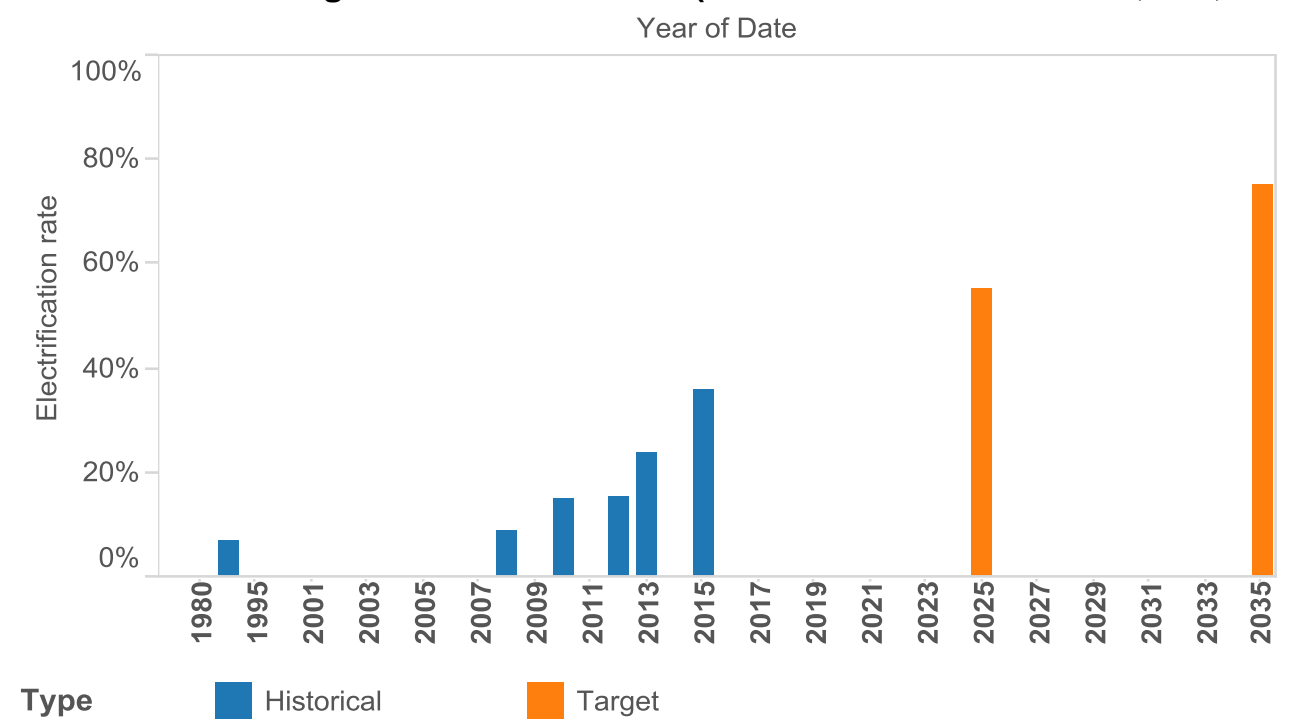

Investment in Tanzania's power sector could be channelled from a number sources: the Tanzanian public (electricity ratepayers and/or taxpayers), international financial institutions and donors, domestic and foreign private investors, or from commercial banks. Rarely is an investment made entirely with funds from a single source. Existing investment arrangements in the sector tap into the sources of funds differently, with varying types of constraints, sharing of risks, costs, and benefits. In the next section, the current industry structure of the Tanzanian power sector is reviewed, following that of its nascent gas sector, a new development which can greatly affect power generation. In the third section, the institutional arrangements that interface different sources of finance and the power sector are presented, with a focus on generation investment, which represents two-thirds of the $\$ 40$ billion investment gap estimate. In the fourth section, the setting of the electricity tariff - the institutional mechanism that regulates cost recovery for power sector investment from ratepayers - 

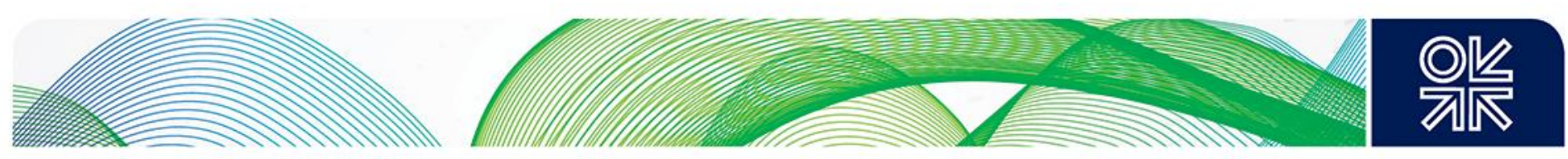

is analyzed in detail. In the fifth section, international experiences from Bangladesh and Côte d'Ivoire, countries which have managed interdependent co-developing gas and power sector investments, are discussed and potential learning points highlighted. Finally, the sixth section provides our concluding remarks.

\section{Review of Tanzania's power and gas sectors}

The development of Tanzania's electricity sector roughly mirrors the development of the national economy as a whole, from small private companies in the former German protectorate in the early $20^{\text {th }}$ century to today's national utility in transition toward liberalization. The natural gas sector's development has followed a different trajectory due to the relative late discovery of gas (1974) and the lack of interest in major development until the recent discovery of important off-shore gas reserves by international oil and gas companies. It is important to understand key development constraints in both sectors, because the national strategy of Tanzania, described in more detail in the next section, is to boost the development of gas-fired power generation given availability of domestic resources. The power and gas industries thus form an interdependent supply chain.

\section{Current power and gas sector governance structure}

The Ministry of Energy and Minerals (MEM) oversees the power and gas sectors in Tanzania. It is mandated to develop energy and mineral resources and has the power to develop and review government policies in the energy sector. The Petroleum Act of 1980 empowers the Minister of Energy and Minerals to grant, renew, suspend, or cancel licences for oil and gas exploration or development, aided by the Commissioner for Petroleum Affairs, appointed by the Tanzanian President (Economic and Social Research Foundation, 2009). As a matter of general practice, all licences for petroleum explorations and production are issued to the Tanzania Petroleum Development Corporation (TPDC), a fully government-owned parastatal organization under the MEM. TPDC then engages with foreign companies through Tanzania's tripartite Production Sharing Agreement (PSA), entered into between the GoT, TPDC, and the investing company, authorizing the company to carry out the petroleum operations on its behalf, granting it exclusive rights over the licence area.

Operational since 2006, the Energy and Water Utility Regulatory Authority (EWURA), an autonomous multi-sectoral regulatory authority, is responsible for the technical and economic regulations of electricity, downstream oil and gas, and the water sector in Tanzania. EWURA awards licences to entities seeking to undertake licensed activities (EWURA, 2012b). ${ }^{4}$ It also approves and enforces tariffs and fees of licensees (including the transmission tariff for gas and the retail tariff for electricity).

Before 1992, Tanzania Electric Supply Company Limited (TANESCO), a vertically integrated, fully state-owned utility, has been the sole company responsible for electricity generation, transmission, and distribution. The company was fully nationalized in 1964, after the United Republic of Tanzania was formed by the merger of Tanganyika and Zanzibar. In 1992, as part of the structural adjustment that started in the mid-1980s, and owing to drought-induced electricity crises, the government lifted TANESCO's monopoly in power generation with the intention of attracting private sector investment to supplement the TANESCO-owned generation capacity (Vagliasindi \& Besant-Jones, 2013). Today,

\footnotetext{
${ }^{4}$ EWURA licensable activities include gas processing, transportation, distribution, import/export, and supply, as well as power generation, transmission, distribution, import/export, and supply, among others.
} 

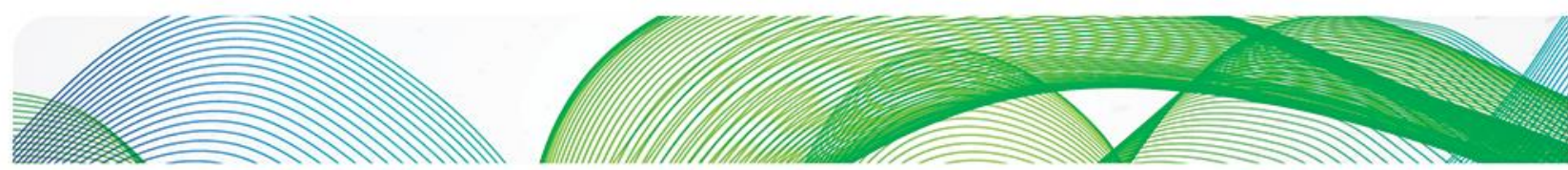

TANESCO remains the sole licensee for transmission and the main licensee for distribution activities, though it purchases electricity generated by a number of Independent Power Producers (IPPs), Emergency Power Producers (EPPs), and Small Power Producers (SPPs). The Rural Energy Agency (REA), another autonomous body under the MEM, operational since 2007, is responsible for the support and facilitation of improved access to modern energy in rural areas by running training programmes, financing rural grid expansion, and partially financing rural energy projects (mostly projects developed by SPPs). ${ }^{5}$

The division of responsibilities among the public entities mentioned above is illustrated in Figure 4.

Figure 4: Existing responsibilities of Tanzanian public institutions in the power and gas sectors

Gas
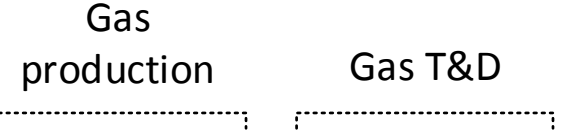
Power
generation

Power T\&D

:

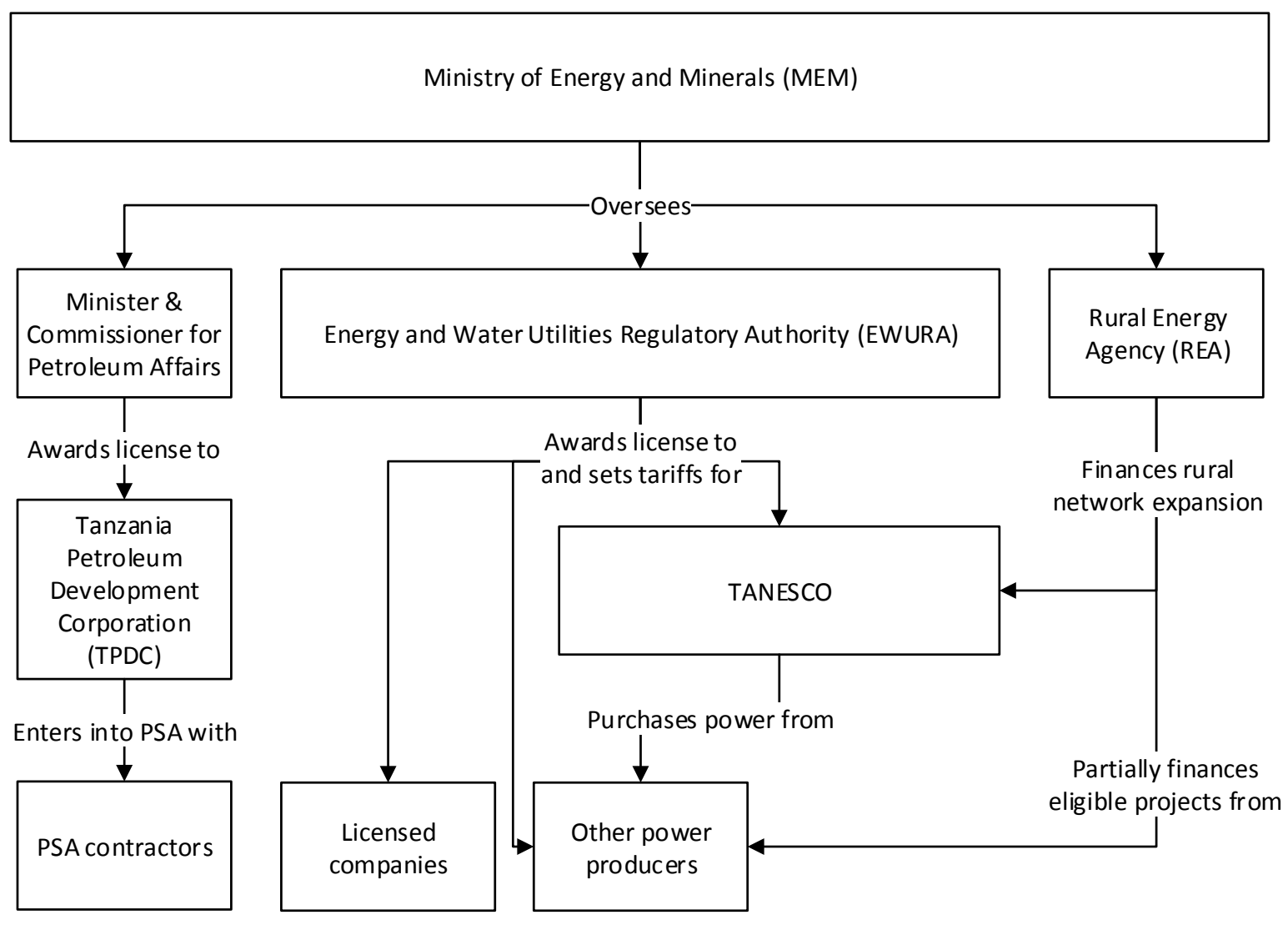

\footnotetext{
${ }^{5}$ Rural distribution networks, after construction is complete, are transferred to TANESCO without payment from TANESCO (Innovation Energie Developpement, 2014).
} 

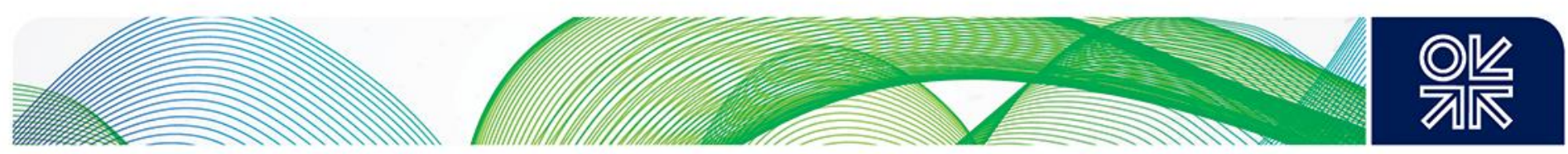

Currently, the MEM chairs the NKRA steering committee for energy, formed by members from the MEM, the Ministry of Finance, President's Delivery Bureau, TANESCO, Commission for Energy and Petroleum Affairs, REA, TPDC, and Kilwa Energy Company Limited (NKRA Energy, 2015).

\section{Gas sector infrastructure}

Currently, there are only two commercialized natural gas projects in Tanzania: Songo Songo, operational since 2004, and Mnazi Bay, operational since 2006. The reserves for these projects were discovered in 1974 and 1982, respectively, but were left undeveloped because exploitation was then not considered commercially viable.

The Songo Songo gas field, with unrisked mean recoverable resources of $551 \mathrm{Bcf}$, located $15 \mathrm{~km}$ from the Tanzanian mainland and $200 \mathrm{~km}$ south of the commercial capital, Dar es Salaam, is operated by Pan Africa Energy (PAE), an Orca Exploration subsidiary, under a PSA with the TPDC. Part of the gas produced from the Songo Songo field, from reserves owned by TPDC, is allocated for use by Songas, a gas-to-power joint venture. The rest is marketed by PAE to TANESCO for power generation and 38 industrial customers in the Dar es Salaam area, ranging from cement, steel, and textile producers to breweries (Bukurura, 2015). Songas owns the gas processing plant and the 225 $\mathrm{km}$ pipeline that connects Songo Songo to Dar es Salaam; as one of the two IPPs, Songas also owns and operates a $190 \mathrm{MW}$ gas-fired power plant in Ubungo, a ward of Dar es Salaam. The "protected gas' allocated to Songas under a 20-year contract until July 2024 is about 229 Bcf of the total reserve. The protected gas is sold at a price of $\$ 0.55 / \mathrm{MMBtu}$, indexed to the USA Consumer Price Index (CPI) over the course of the 20-year contract, reflecting the costs that PAE incurs for delivering the gas to Songas. In other words, the wellhead price of protected gas is free; this was agreed upon as part of the gas-to-power project. For the marketing of non-protected gas, PAE's Portfolio Gas Supply Agreement (PGSA) with TANESCO has set the contract wellhead price for gas delivered to be $\$ 1.98 / \mathrm{MMBtu}$, with additional processing and transportation tariff of $\$ 0.59 / \mathrm{MMBtu}$, both indexed to the annual average USA CPI (White \& Case LLP, 2011). The rest of gas that is marketed from Songo Songo is priced at a maximum of 75 per cent of the price that the buyer pays for equivalent liquid fuel (Gratwick, Ghanadan, \& Eberhard, 2007).

The Mnazi Bay project, operated by Maurel et Prom, co-owned by Wentworth Resources and TPDC, has unrisked mean recoverable resources of 1,596 Bcf. Other than supplying a gas-fired power plants of $18 \mathrm{MW}$ belonging to TANESCO, this resource had been largely stranded. By August 2015, however, the construction of a pipeline from Mnazi Bay to Dar es Salaam, with connection to Songo Songo, had been completed and first gas delivery taken place (Rigzone Staff, 2015). The pipeline is owned and operated by the Gas Supply Company (GASCO), a subsidiary of TPDC within its newly established downstream directorate. The gas distribution network is under expansion to supply more residential, institutional, and industrial customers. Also, according to TPDC, dual-fueled vehicles, running on compressed natural gas and gasoline, are being encouraged via the planned building of natural gas filling stations (TPDC, personal communication, 2016). The distribution of existing Tanzanian gas sector infrastructure is shown in Figure 5. Given that the deep-water natural gas finds in Tanzania, discovered in recent years, are located near Mtwara, the newest pipeline is expected to transport a proportion of deep-sea production to Dar es Salaam, if these projects come online (see Figure 7). In the short to medium term, however, power generation expansion based on gas use and other gas consumption depends upon the more modest coastal margin reserves. 

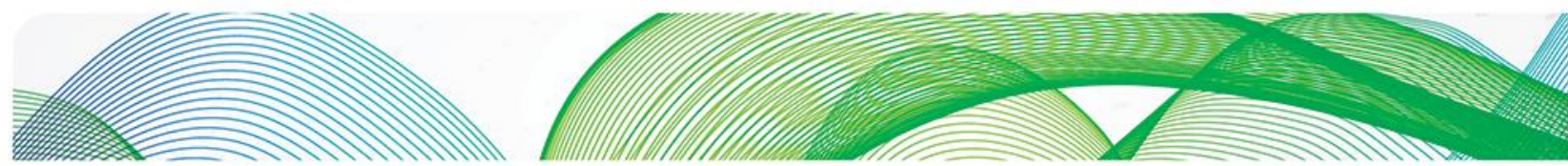

O는

Figure 5: Natural gas fields and pipelines in Tanzania

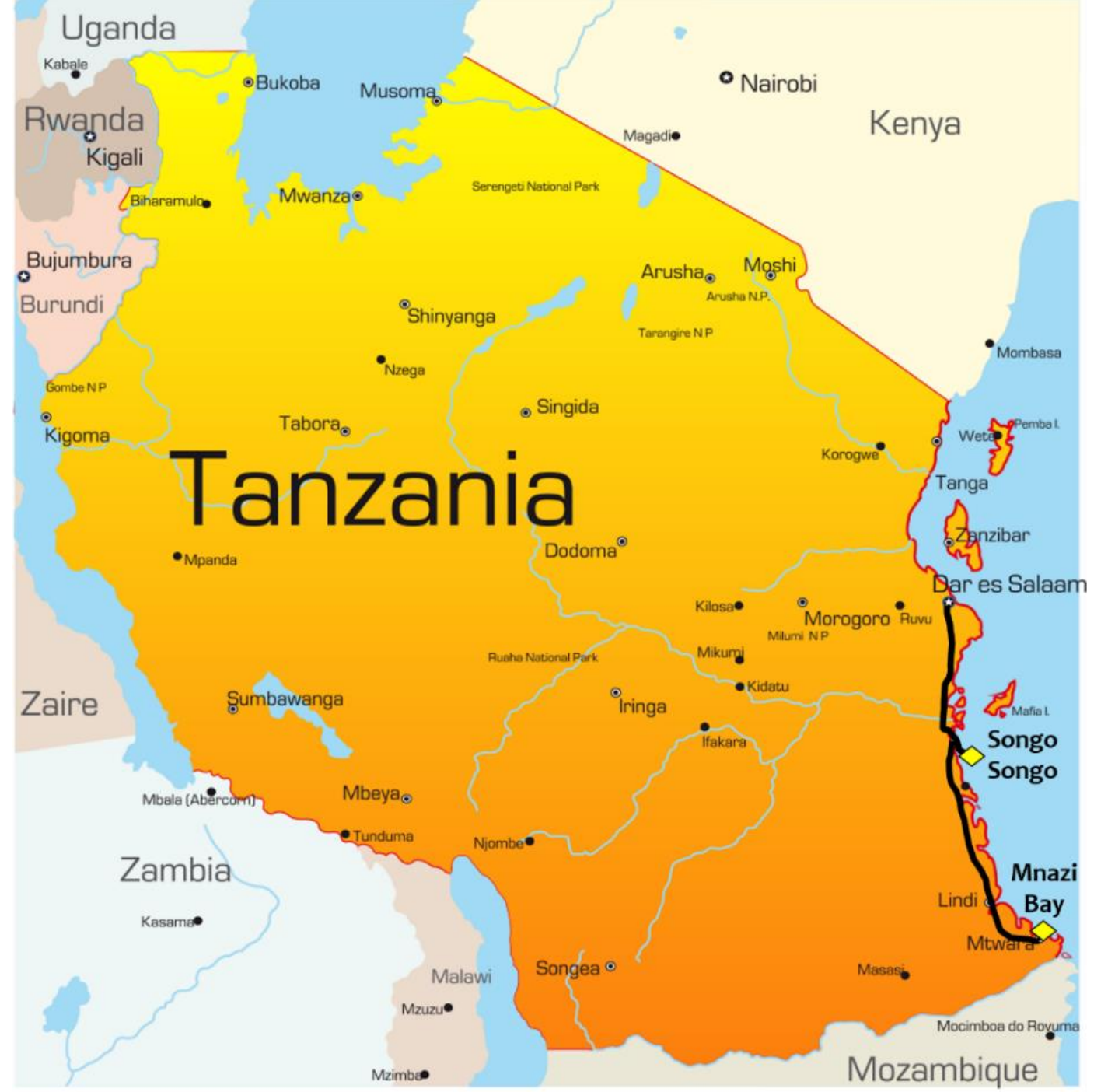

\section{East African gas boom}

Since 2010, there have been significant deep-water gas finds in East Africa due to convergence of technological, market, and political drivers: increased capability in seismic interpretation and deepwater drilling/completion, expected rise of LNG demand in the high value markets of Asia, and governments supportive of gas project developments (Ledesma, 2013; Wood Mackenzie, 2015). These discoveries have propelled Tanzania and Mozambique to become the focus of attention as a source of new global gas supply. In Figure 6, the latest proven reserves figures for the two countries are shown together with other high-reserve countries for comparison (EIA, 2014; Ng'wanakilala, 2015). 

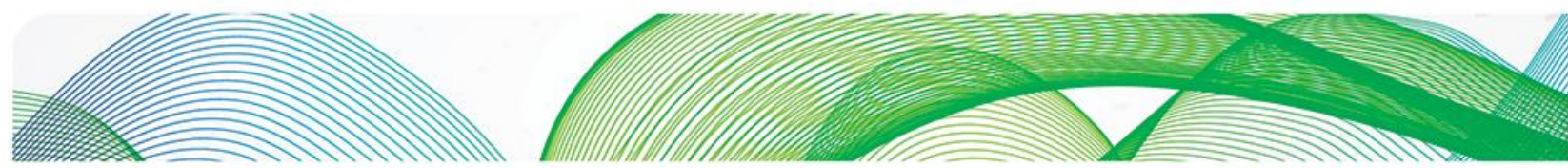

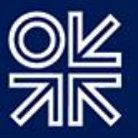

Figure 6: Countries with highest proven gas reserves (Data source: all from ElA for end of 2013 except for Mozambique and Tanzania)

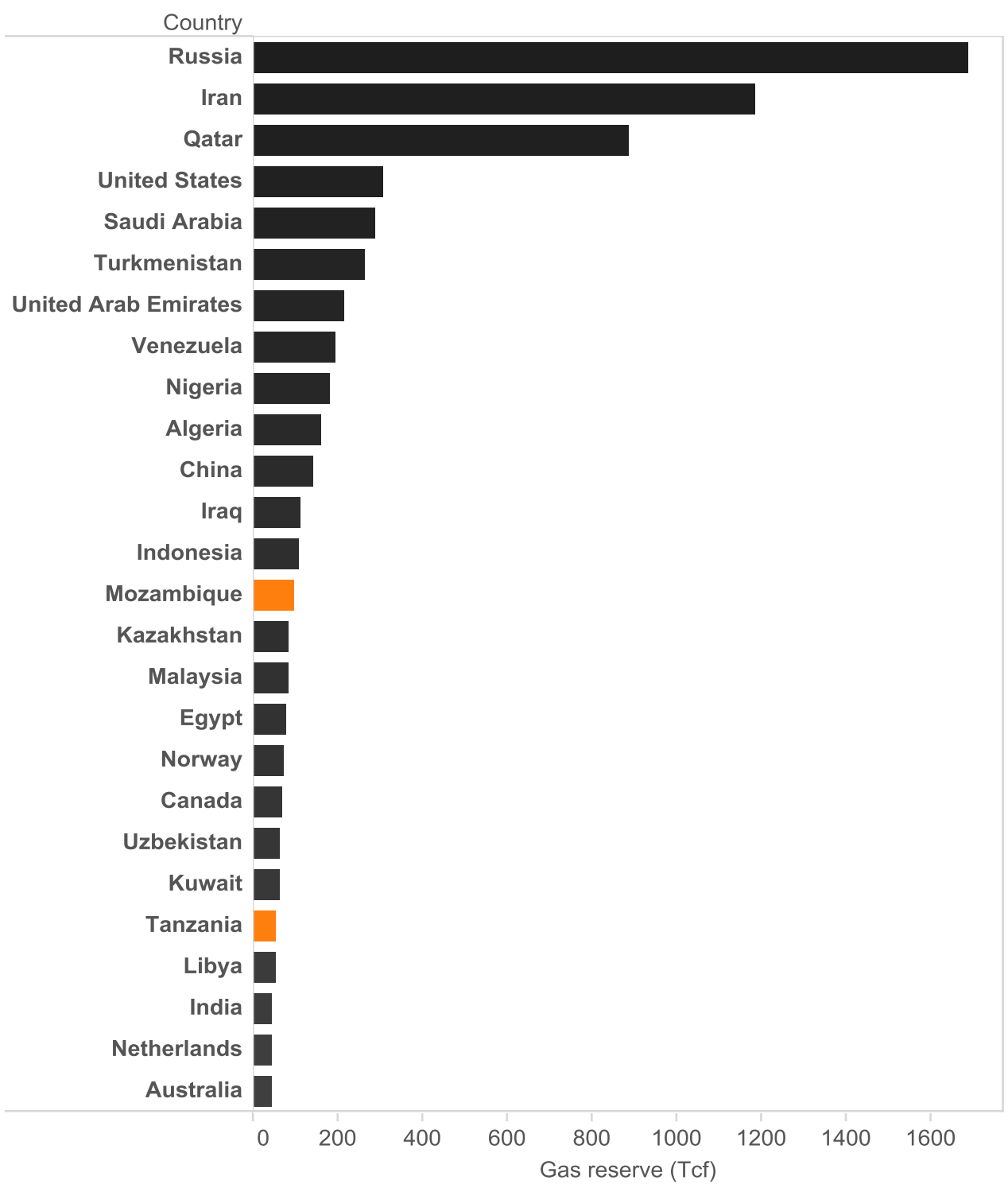

By December 2012 there were 26 PSAs signed with 18 oil exploration companies seeking to conduct exploration activities both offshore and onshore ${ }^{6}$ (Ministry of Energy and Minerals, 2013b). The most significant natural gas discoveries so far have been made by major exploration companies including

\footnotetext{
${ }^{6}$ In July 2014, a leaked PSA between Statoil and TPDC has caused controversy within the country about whether Tanzania will gain the full benefits of its sizeable gas deposits. In November, the chairman and director-general of TPDC were temporarily arrested after the state body refused to provide the Public Audits Committee with the details of the confidential contracts (Manson, 2014; The Economist, 2014).
} 

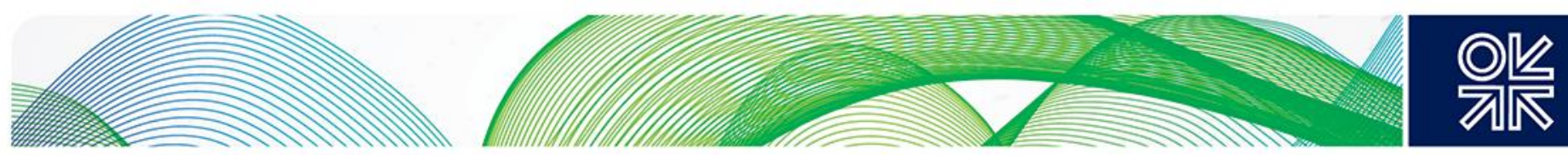

BG, ${ }^{7}$ ExxonMobil, Ophir, and Statoil in offshore blocks 1, 2, 3, and 4 (Figure 7). At the request of the Tanzanian government, an integrated project team has been set up involving the four companies to study the viability of developing a joint onshore LNG facility where infrastructure costs will be shared. It is believed that the gas uncovered should be enough to support a two-train 10 million tonne per annum (mtpa) LNG plant and meet potential domestic market obligations (Gas Strategies, 2014). Along with neighbouring Mozambique, Tanzania is in a race with Australia, the United States, and Canada to build LNG liquefaction terminals, aiming to exploit a gap in global supply that is expected to emerge in the 2020s (Ledesma, 2013).

Figure 7: Recent Tanzania offshore natural gas discoveries (Source: Gas Strategies)

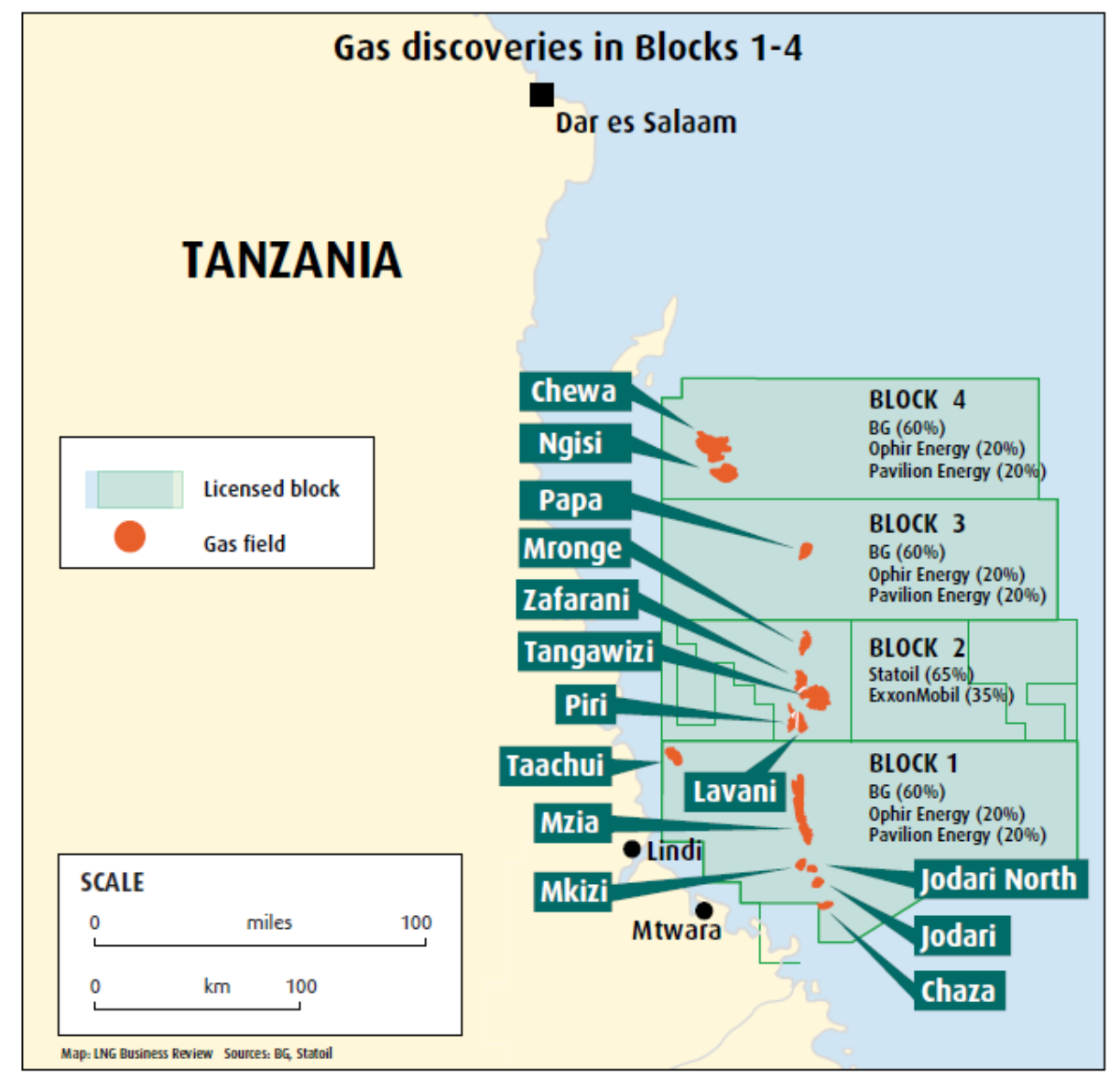

Domestically, the Lindi Bay LNG export project, costing about $\$ 20$ billion, represents more than a third of the country's GDP ( $\$ 49$ billion in 2014) and the largest investment ever in Tanzania. Government revenues from the LNG project may reach $\$ 3$ billion annually (Norton Rose Fulbright, 2014a; Pedersen \& Bofin, 2015). By comparison, total government revenues in 2011-12 amounted to $\$ 4.4$ billion and official development assistance to $\$ 1.8$ billion. The Tanzanian government is in the

\footnotetext{
${ }^{7}$ The takeover of BG group by Shell places the latter back in the East Africa gas scene after losing a bidding war for stakes in Mozambique to PTT Exploration \& Production (Bloomberg, 2015).
} 

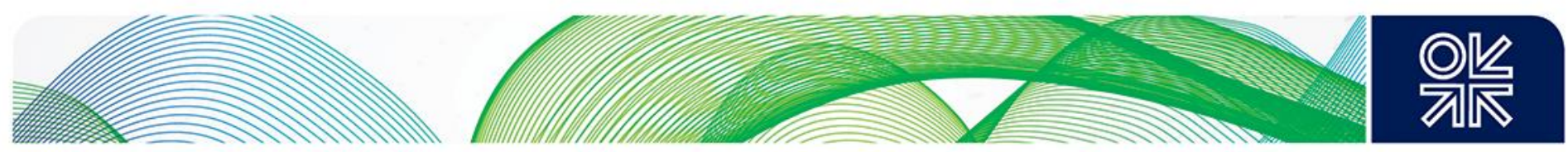

process of updating its fiscal, legislative, and regulatory framework that governs the gas sector to reflect changes in the sector. Since 2013, a flurry of new energy legislation and review of existing instruments has been proposed in Tanzania. The National Natural Gas Policy, adopted in 2013, applies to the midstream and downstream segments and emphasizes the following elements: precedence given to supplying the domestic market over the export market ${ }^{8}$, local content sourcing, potential requirement for International Oil Companies (IOCs) to be listed on the Dar stock exchange, mandatory Corporate Social Responsibility obligations, and the establishment of a Natural Gas Revenue Fund, managed by the Bank of Tanzania (Norton Rose Fulbright, 2014b). Other important pieces of legislation are the Petroleum Act 2015, the Tanzania Extractive Industry (Transparency and Accountability) Act 2015, and the Oil and Gas Revenues Management Act 2015. Together, they repeal the Petroleum (Exploration and Production) Act 1980, covering upstream petroleum operations, and the Petroleum Act 2008, covering mid and downstream petroleum supply options. The Petroleum Act 2015 establishes new institutions, namely an Oil and Gas Bureau within the Office of the President to advise the Cabinet and a Petroleum Upstream Regulatory Authority - distinct from EWURA and TPDC - that advises the Minister of Energy and Minerals on negotiations of PSAs, the implementation of local content in the petroleum sector, and the granting of exploration, development, and production licences. It also designates TPDC as the official National Oil Company (NOC), which is the only entity that can be granted petroleum rights including licences. As these licences are not transferrable, private sector participants must partner with the NOC, which shall retain 25 per cent interest in any joint venture vehicle (Clyde\&Co, 2015). The Petroleum Act also makes provision for the NOC to have a designated subsidiary as the gas aggregator. This new entity will have the exclusive right to purchase, collect, and sell natural gas from producers. Private sector operators, given the applicable licences have been obtained, are allowed to operate midstream and downstream infrastructure after acquiring gas from the aggregator. ${ }^{9}$ The Extractive industry act (Transparency and Accountability) proposes to publish all Mining Development Agreements and PSAs through a website, including those entered into during and before the passage of the bill. Altogether, these newly passed pieces of legislation reflect a more assertive bargaining position of the Tanzanian government with potential PSA counterparties (Pedersen \& Bofin, 2015).

The speed and volume of LNG exports from Tanzania will be determined not only by the amount of gas in place and domestic politics and policies, but also by the economics of the proposed export projects and the global demand for LNG. By extension, the availability of off-shore gas resources for domestic use (the domestic off-take component of PSAs with LNG developers), is also contingent upon external conditions. Preliminary assessment suggests that the landed costs in Asia for gas from East Africa, US Gulf, and Australia are very similar, therefore the price and contract terms of LNG sales will play an important role in the competition for the Asian market (Ledesma, 2013). As of February 2016, there is no LNG off-take agreements between the LNG project developers and potential buyers. Key LNG purchasers in Asia are not in a rush to conclude contracts, since there will soon be an oversupply as projects already under construction come on-stream. Furthermore, Wood Mackenzie, in a global gas analysis published in September 2015, recognizes that, given $250 \mathrm{mtpa}$ of global LNG supply and a further $140 \mathrm{mtpa}$ under construction, the global market will struggle to absorb such a large supply increase, especially since Asia - China in particular - has shown subdued industrial output and increasing fuel competition driven by the low price of oil (Tomnay, 2015). Therefore, the final investment decision, initially planned for 2016, and the subsequent

\footnotetext{
${ }^{8}$ A proportion of proven reserves are to be dedicated to the domestic market based on reserve assessment.

${ }^{9}$ Three types of licences are available: processing, transportation and storage licence; liquefaction, shipping and regasification licence; distribution licence.
} 

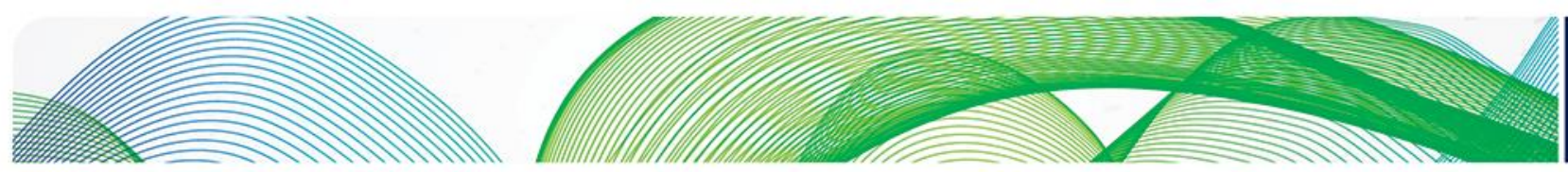

敏

commissioning of the export facility, initially planned for 2020, are expected to be delayed beyond the original timeline. The uncertain global outlook casts shadows over the economic feasibility of developing Tanzania's offshore gas resources.

\section{Power sector infrastructure}

Today, TANESCO remains the main company which owns and operates downstream power sector infrastructure. The $4 \mathrm{MW}$ Mwenga hydro project is the only other company that also holds a licence for distribution and supply activities. The main grid owned and operated by TANESCO consists of $4,869 \mathrm{~km}$ of transmission lines at $220 \mathrm{kV}, 132 \mathrm{kV}$, and $66 \mathrm{kV}$. The lines are concentrated along its main transport and development corridors, where most of the population and agricultural activity is concentrated: from Dar es Salaam west to Dodoma, then northwest to Mwanza on Lake Victoria in the northern part of the country, connecting to Uganda and Kenya, from Dar es Salaam southwest to Mbeya and on to Zambia; from Dar es Salaam north to the mountainous area around Kilimanjaro in the northeast of the country, near Arusha (Figure 8). The development of road, water, information, and communication technology infrastructure backbone broadly follow this pattern. The rest of the country is less densely populated and has only fragmentary infrastructure coverage.

Figure 8: The Tanzania transmission grid (The Business Year, 2014)

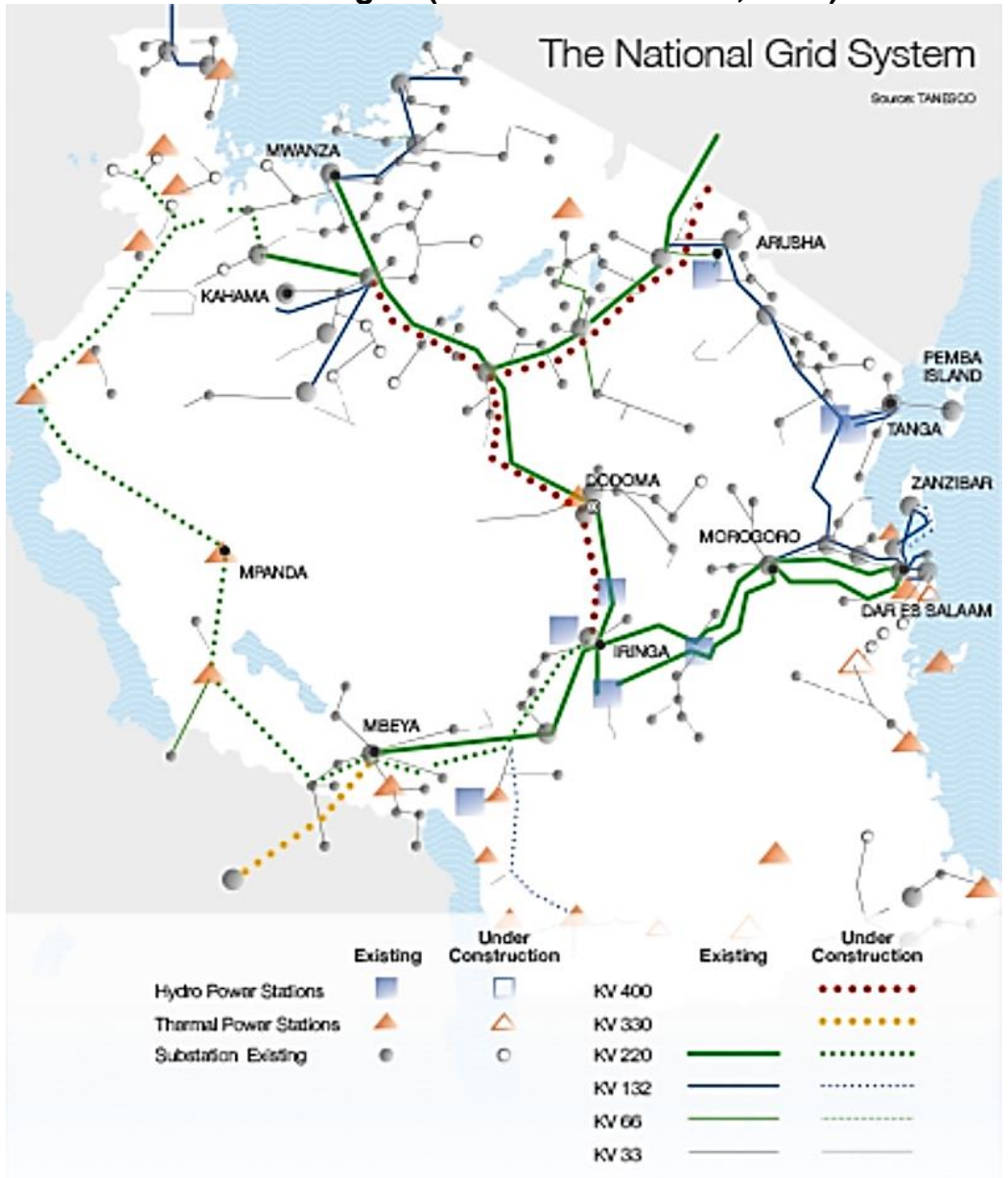



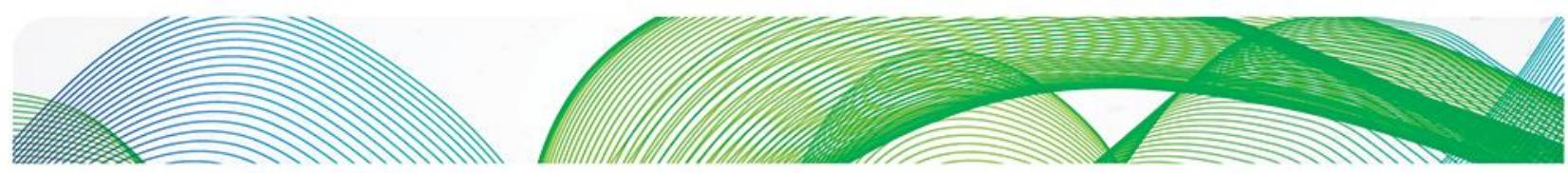

O资

Based on the availability of connection to the national grid, the installed power generation capacity in Tanzania can be divided into two categories: on-grid facilities which are connected to the main grid connecting major load centres, and off-grid facilities connected to isolated mini grids. ${ }^{10}$

Of the first type, there were $561 \mathrm{MW}$ of hydropower projects commissioned between 1964 and 2000, dominated by the Kidatu Dam (204 MW) and the Kihansi Dam (180 MW). This infrastructure is the legacy of the 'Big Dam Era', during which large hydroelectric dam projects were funded by development aid programmes with sponsors such as the World Bank, the Swedish International Development Cooperation Agency (SIDA), and the Norwegian Agency for Development Cooperation (NORAD). Currently, these hydroelectric facilities are owned and operated by TANESCO. Increasingly, they suffer from recurrent droughts and cannot be depended upon to generate electricity reliably. ${ }^{11}$ Hydropower stations, responsible for about half of the electricity generated in the country, are located in southern Tanzania, while most load centres are in the north. There are also fossil fuelfired, on-grid power generating plants built since the 2000s, owned and operated by different companies, reflecting the lifting of TANESCO's monopoly in generation in 1992. Fossil fuel-fired generation plants owned and operated by IPPs came online in the early 2000s, ten years after the lifting of monopoly: Independent Power Tanzania Limited (IPTL) ${ }^{12}$ in 2002 and Songas - the joint venture mentioned previously - in 2004. In 2011, TANESCO contracted EPPs ${ }^{13}$, US company Symbion Power and Glasgow-based Aggreko, to bridge the electricity supply gap caused by droughts and to provide diesel-fired rented capacity. Since 2010, a few SPPs are also active, providing electricity to the grid burning local biomass feedstock or generating small-scale hydroelectricity.

In regions where connection to the grid is not available, TANESCO owns and operates isolated diesel generator-powered mini-grids mainly in the western belt from Bukoba to Songea. The mini-grids located on the eastern shore, namely in Somangu and Mtwara, small-scale gas-fired power plants, supplied by natural gas from the Songo Songo and Mnazi Bay projects. Some SPPs contracted also provide electricity to the mini-grids.

The breakdown of installed generation by owner, type of generator and grid connection status is shown in Figure 9. A further $15 \mathrm{MW}$ of generation capacity is available through imports from Uganda and Zambia.

\footnotetext{
${ }^{10}$ The installed capacity of captive generation, generators owned and operated by households and businesses, is not accounted for. Only anecdotal data on such capacity is available.

${ }^{11}$ Droughts have been recorded for the years 1967, 1977, 1984, 1988, 1990, 1996, 2003, 2004, 2006, 2011 (Masih, Maskey, Mussá, \& Trambauer, 2014).

${ }^{12}$ Changing hydrological conditions in the country between 1994 (IPTL project conception) and 1997 (end of IPTL construction) and higher than expected construction costs led TANESCO to seek rescinding the PPA signed with IPTL. The arbitrator, World Bank's International Centre for Settlement of Investment Disputes (ICSID) ruled against it finally in 2001, upholding the original PPA with some adjustments. In 2014, two senior politicians were ousted following a scandal surrounding misuse of the TANESCO-IPTL joint escrow account (Gratwick et al., 2007; Kabendera \& Anderson, 2014).

${ }^{13}$ The former Prime Minister Edward Lowassa resigned in 2008 over allegations of improperly awarding of an EPP contract to US-based Richmond Development in 2006 (BBC News, 2008).
} 

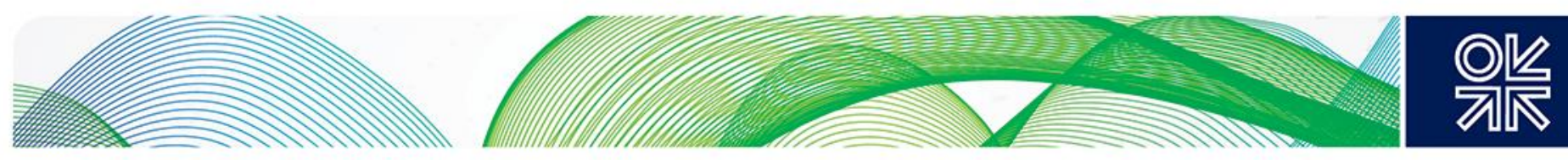

Figure 9: Installed generation capacity in Tanzania by ownership, generation type and grid connection (see Table 11 in the Appendix for detailed breakdown)

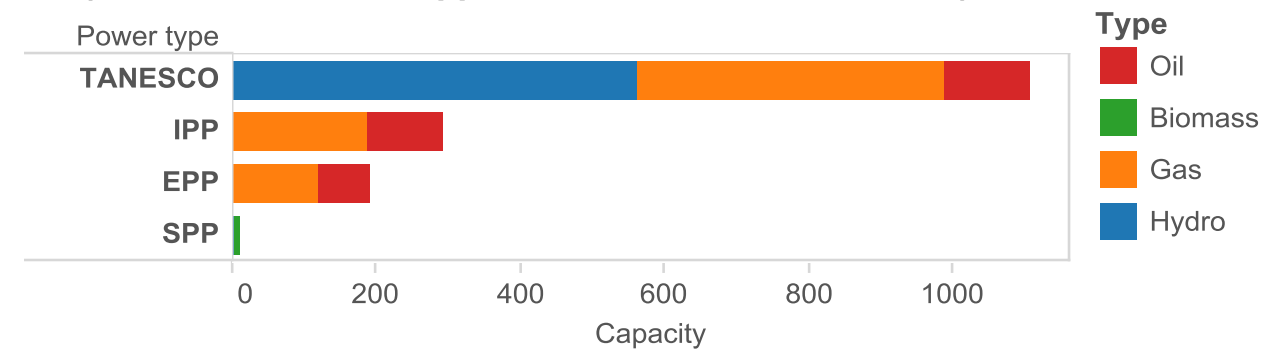

Under the NRB, the energy NKRA steering committee is prioritizing seven generation projects to expand the country's installed capacity, of which the Mwanza oil-fired generation plant has been commissioned in 2013.

- In early 2016, 70 MW of the 150 MW Kinyerezi I gas-fired power plant funded by TANESCO, the first of a set of four located in the south of Dar es Salaam and supplied by gas from the MtwaraDar es Salaam pipeline, was commissioned.

- Kinyerezi II, construction of which began in early 2016, will have a capacity of $240 \mathrm{MW}$. It is owned by TANESCO and financed by loans from the Development Bank of Africa, the Japan Bank for International Cooperation, and the Sumitomo Mitsui Banking Corporation.

- Kinyerezi III, to be financed by China Power Investment Corporation, a state-owned enterprise, with 320 MW capacity in phase 1.

- Kinyerezi IV, to be financed by China's Poly Group, a state-run conglomerate, with $330 \mathrm{MW}$ capacity in phase 1 . Both Kinyerezi III and IV earmarked to be PPPs and are currently seeking private sector partners.

- The 50 MW Geo Wind Power project, a joint venture of the National Development Corporation, TANESCO and Power Pool East Africa, financed by the Exim Bank of China, is expected to begin construction in 2016.

- The 210 MW Kilwa Energy project, owned by Kilwa Energy Company, is seeking financial close.

Beyond the prioritized projects, the Symbion Southern Electrification Project, a $400 \mathrm{MW}$ gas-fired power plant and a $400 \mathrm{kV}$ transmission line from the plant in Mtwara to Songea, is being negotiated as a PPP between TANESCO and US-based (Washington DC) Symbion Power - a company already operating within Tanzania as an EPP (Symbion Power, 2015; Wentworth Resources Limited, 2015c). Furthermore, between 2013 and 2015 a total of $155 \mathrm{MW}$ of potential small-scale hydro, biomass, and solar PV SPPs have sent letters of intent to EWURA, a prerequisite for project implementation (Tsakhara, 2015). If all planned projects were to come online by 2020 , the resulting $1,705 \mathrm{MW}$ of capacity would mean a doubling of Tanzania's on-grid installed power generation capacity, which stands at around 1,520 MW. Beyond the projects already mentioned, there is another 4,332 MW of tentatively planned generation capacity, where project names have been mentioned in the 2012 Power System Master Plan, but no procurement work has started (Figure 10). 

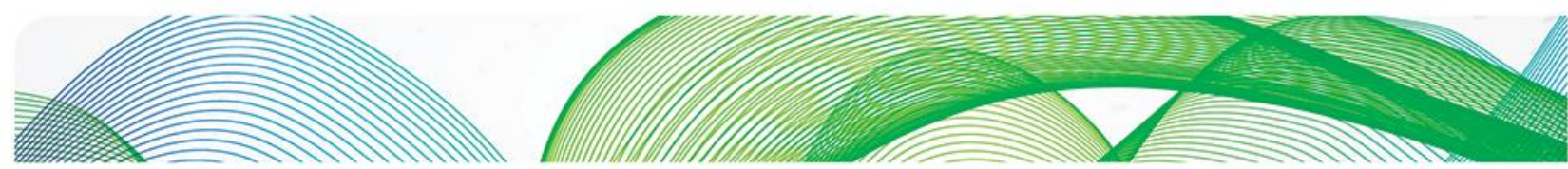

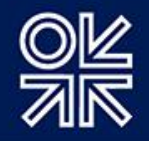

Figure 10: Breakdown of Tanzania's generation capacity expansion plan (see Table 11 in the Appendix for detailed breakdown)

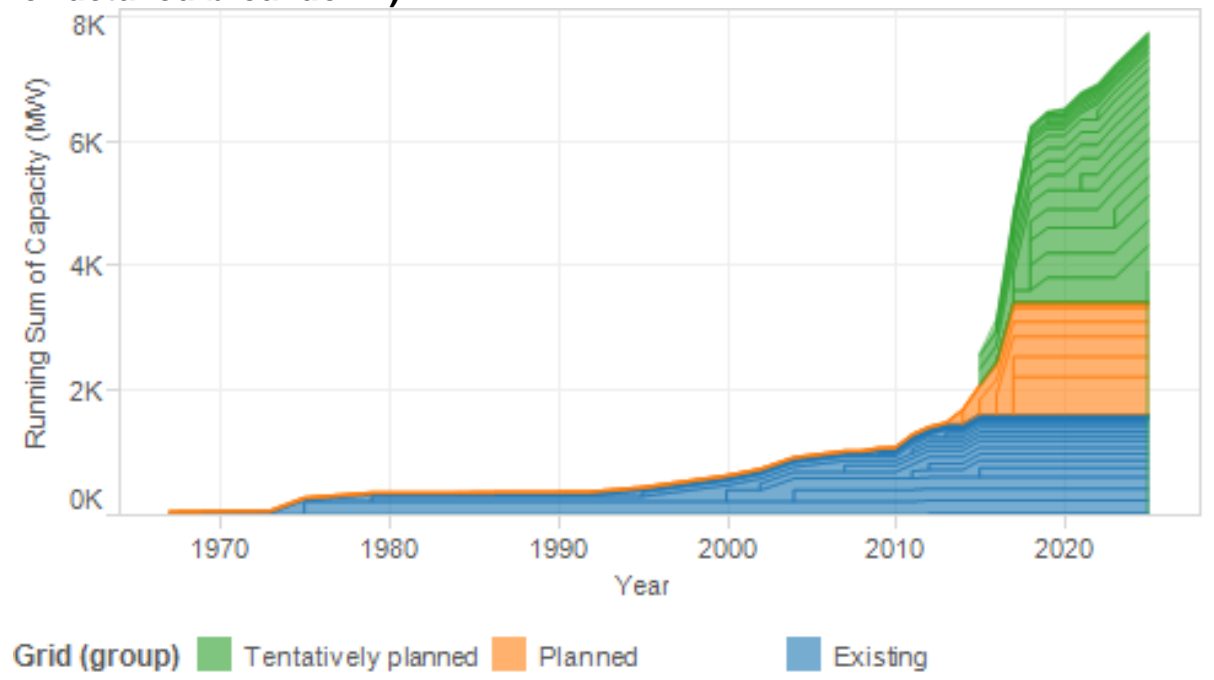

Transmission and distribution losses in Tanzania are comparable to its neighbours (Zambia, Kenya, and Mozambique), but significantly higher when compared to countries around the globe, standing at 18 per cent in 2012 (Figure 11). High losses in distribution have been attributed to aging infrastructure, unplanned extensions of distribution lines and the overloading of equipment due to inadequate investment in the past (Kihwele, Hur, \& Kyaruzi, 2012). Other than these technical causes, electricity theft is also believed to contribute to non-correspondence between billed electricity and electricity fed to the power grid, on small and large scales (Mwamunyange, 2013b). Such commercial losses are thought to make up around half of the total transmission and distribution losses (NKRA Energy, 2015).

Figure 11: Electric power transmission and distribution losses in 2012 (Data source: World Bank)

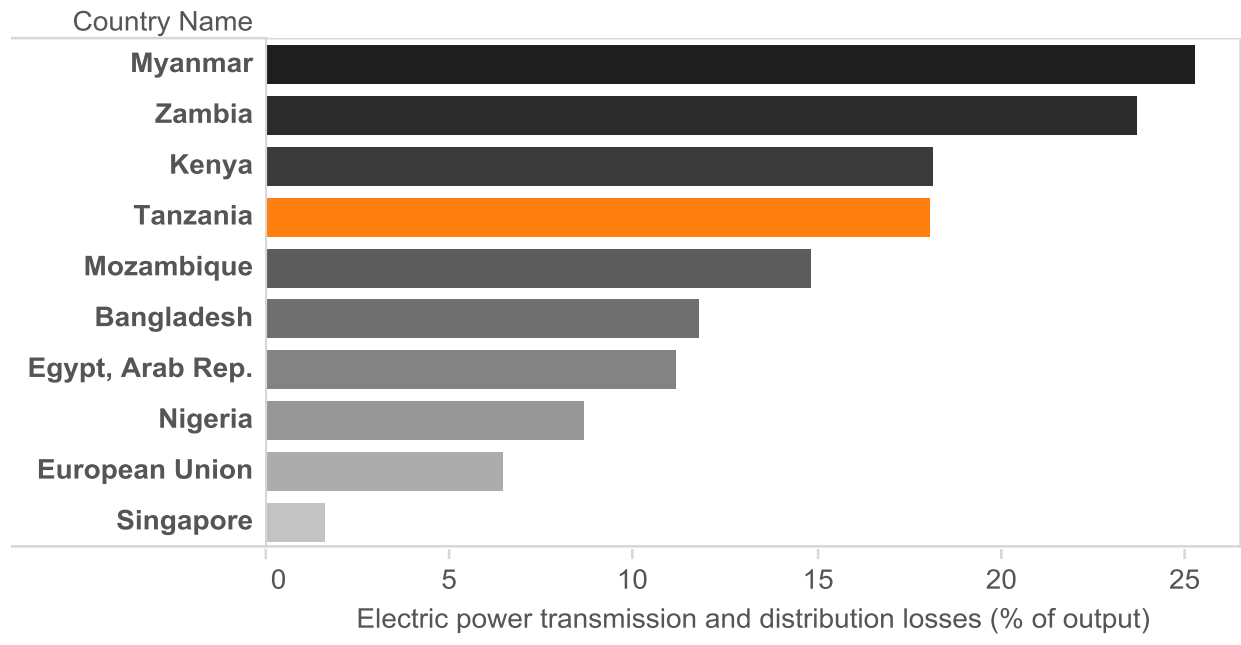



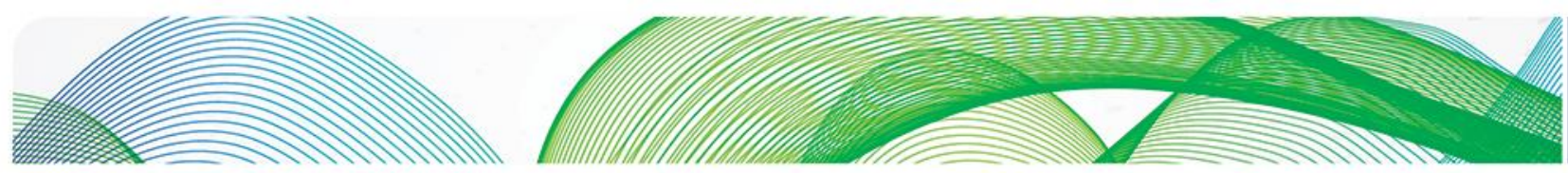

애잠

In the near term, the transmission investment announced by TANESCO reflects the goals of integrating the gas-producing south with the main grid, reinforcing the transmission backbone around and to the west of Dar es Salaam, and expanding the grid toward inner Tanzania, where dieselpowered isolated mini-grids operate (see Figure 12).

Figure 12: Current and planned power infrastructure (Data source: Lazimah, 2014; NKRA Energy, 2015)

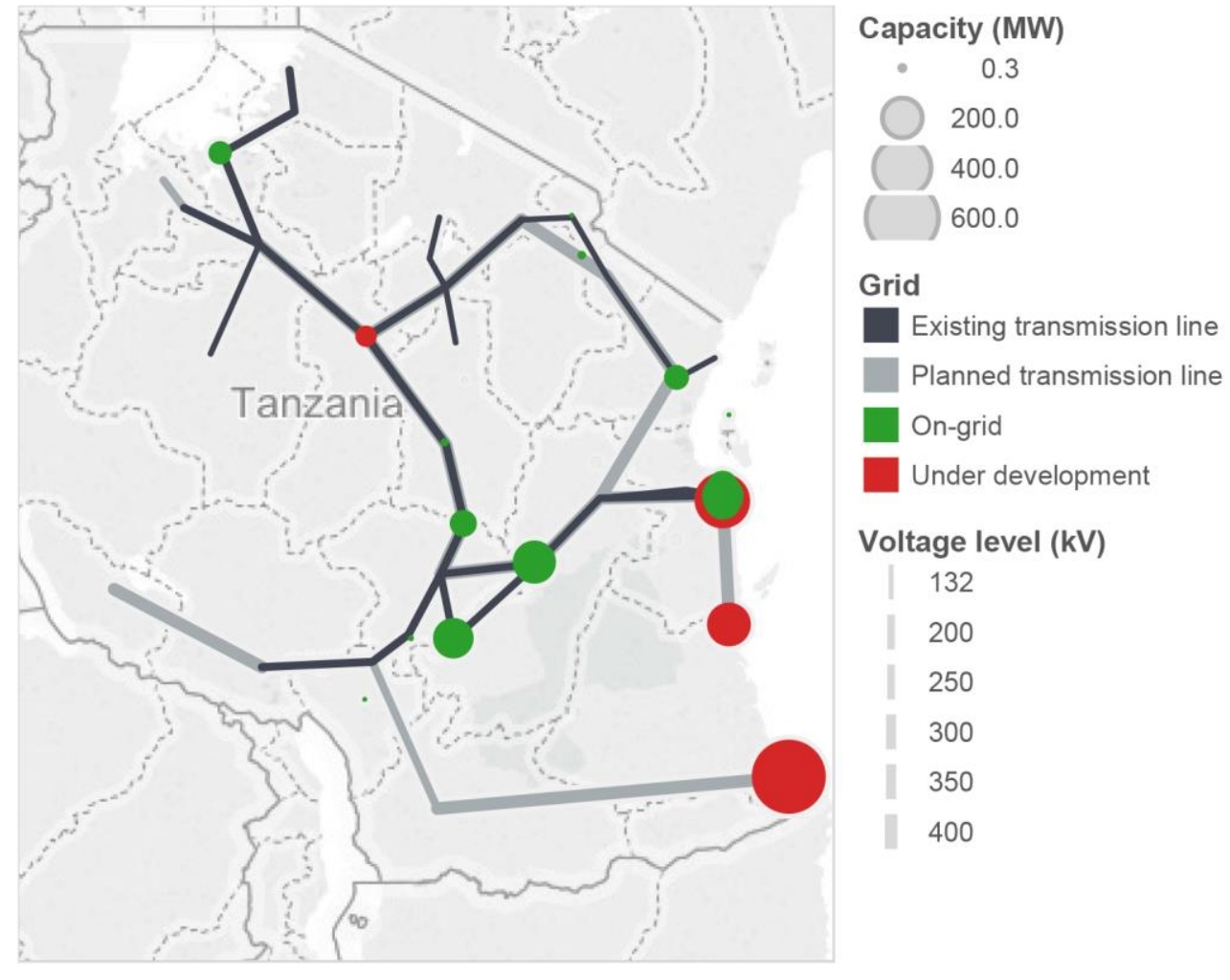

Between 2000 and 2012, annual consumption of electricity in Tanzania increased from 1,861 GWh to $4,419 \mathrm{GWh}$. Of the total electricity demand, half is residential demand and half is more or less evenly split between industrial consumption and commercial demand. Drivers in electricity demand growth include increasing mining activity (mines either operate their own generators or connect to the grid), population growth, urbanization, electrification rate increase, and increase in household consumption level (Castellano et al., 2015; Tsakhara, 2015). Extrapolating from the current trend the trend line grows exponentially, with $R^{2}=0.976$ - in 10 years, annual residential demand is expected to increase to 5,000 GWh, commercial and industrial each to about 2,000 MWh, which corresponds to a doubling of current demand to 9 TWh (Figure 13). Forecasts performed by MEM in 2012 estimated a quadrupling of demand by 2025 to $20 \mathrm{TWh}$, if unconstrained by the grid's capacity to deliver electricity (Ministry of Energy and Minerals, 2012). Another recent analysis forecasts a total electricity demand of 14 TWh by 2025 (Kichonge, John, Mkilaha, \& Hameer, 2014). Regardless of the exact figure, power demand in Tanzania is expected to experience significant growth in the near term, in tandem with its economic growth. 

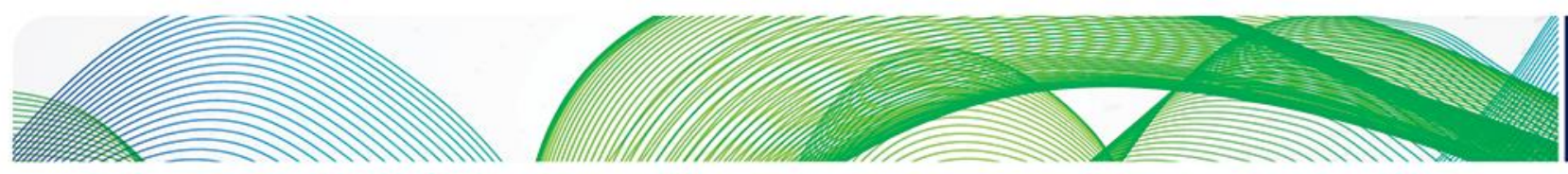

O는

Figure 13: Extrapolation of electricity consumption trend in Tanzania (Data source: IEA)

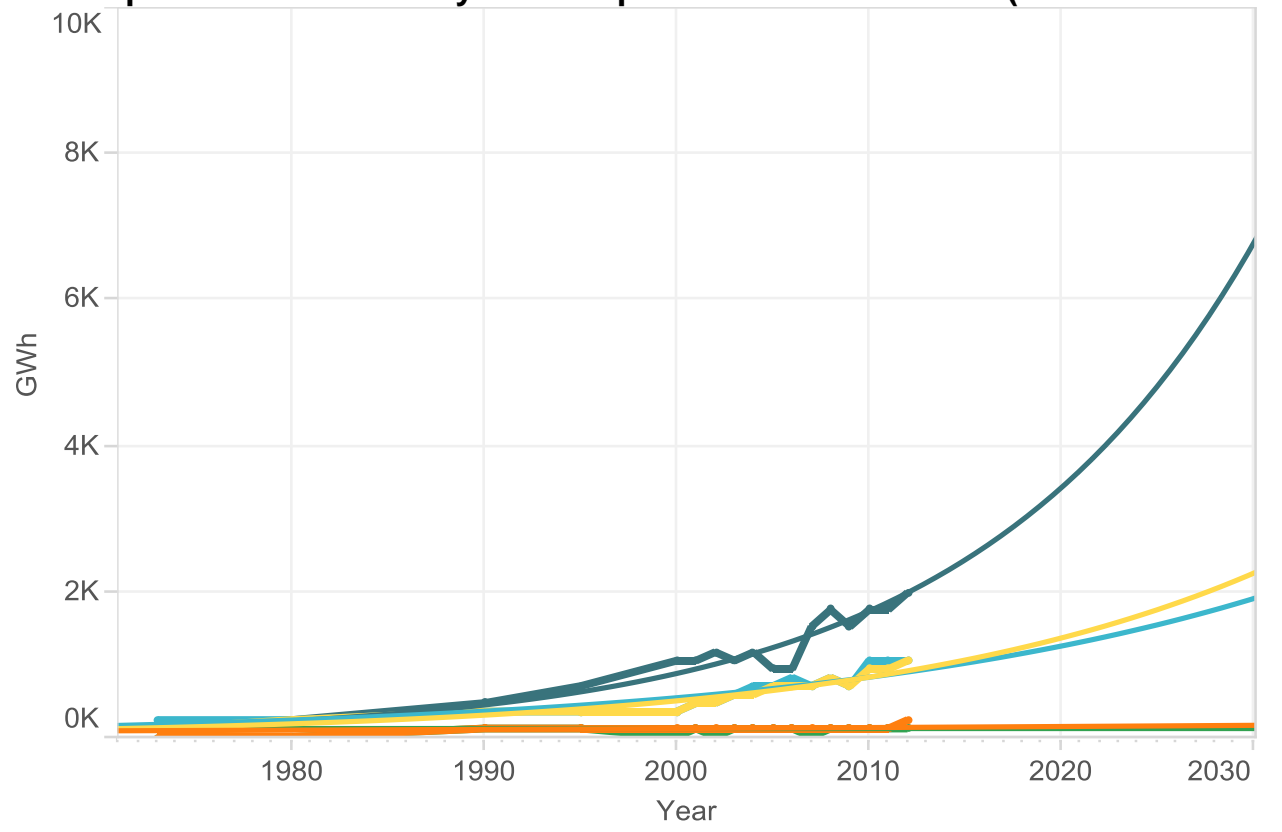

Electricity consumption

$\begin{array}{ll}\text { Agriculture } & \text { Industry } \\ \text { Commercial } & \text { Other }\end{array}$

Residential

\section{Access to electricity}

Electricity was first used in Tanzania in 1908, when a railway company installed the first power generator in what was then Germany's East African colony in Dar es Salaam. In the following four decades, colonial administrators, utility company officials, and (after 1931) managers of the privatized Tanganyika power utility limited their efforts to meeting the demand of the small European communities in the city and of the plantation agriculture, instead of developing new markets among Africans (Straeten, 2015). Thus, by the 1950s, when universal access to electricity was almost achieved in Europe and the United States, electricity was only available for a few hundred customers in the capital and some towns of Tanganyika, then under British mandate.

After its independence in 1962, Tanganyika united with neighbouring Zanzibar to form the United Republic of Tanzania in 1964. In that same year, the government of Tanzania acquired shares in the private Tanganyika Electricity Supply Company and Dar es Salaam Electricity Supply Company, which became fully nationalized and merged to form TANESCO in 1975 (Ghanadan, 2009). At the beginning of this period, in 1960, total installed capacity in the country had been below $50 \mathrm{MW}$. Then, focusing on large-scale generation and the establishment of a centralized power grid, with credit from the World Bank and technical assistance from SIDA, TANESCO added $380 \mathrm{MW}$ of hydropower to the national grid by 1990. The overall electrification rate was 6.8 per cent in 1990 (IEA), and though access in urban areas deepened, the lack of any coordinated rural energy planning (Straeten, 2015) meant that less than 1 per cent of the rural population had access to electricity in 1990. 

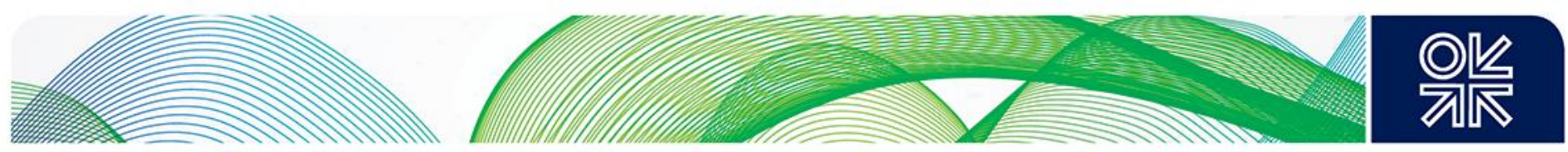

In 1992, catalyzed by macro-reform priorities, national energy policy, drought-induced electricity crises, and changes in World Bank's lending policy, the GoT initiated reforms in the power sector, which originally aimed to restructure and unbundle the power sector for eventual privatization (Diu, 2011). TANESCO was performing adequately throughout the 1970s and 1980s, but the performance of the utility gradually declined toward the end of the 1980s. It was unable to cover its operation and maintenance costs and debt service repayment from its collected revenue: the average tariff was below costs levels in the early 1990s due to reluctance to increase tariffs during prescribed currency devaluation. Furthermore, TANESCO experienced difficulties in enforcing payments for services and arrears. The weak financial position of the company led to insufficient investment in generation capacity and network reinforcement, power outages and distribution losses increased accordingly, lasting until the end of the 1990s despite tariff increases in the middle of that decade ${ }^{14}$.

In 2002, TANESCO was placed under a two-year management contract with the South African company NET Group Solutions, in pursuit of a financial turnaround in view of privatization. NET Group Solutions implemented measures to increase revenues, mainly through enforcing collections and arrears payments and applying disconnection in the case of non-payment, even to high-profile customers such as the police or the national post office. Between 2002 and 2004, TANESCO revenue collection doubled. The management contract was extended for two years in 2004, during which time the focus was to include improvement in electrification and system reliability targets. By the end of the contract, technical turnaround was limited, with poor hydrological conditions, costly contracts with IPPs, and insufficient tariff rates ${ }^{15}$ cited as obstacles. Electrification rates stagnated between 1990 and 2008.

Currently, the main drivers of electrification in Tanzania are political priorities and development policies, as demonstrated by the creation of the REA in 2005 and the setting of aggressive electrification targets. The target-driven National Electrification Program is financed by the REAmanaged Rural Energy Fund, which is funded by donor contributions, levies on electricity, and levies on liquid fuel import and purchase. At the end of 2013, TANESCO had about 1.3 million connected customers. Beginning in 2014, a densification program is proposed to increase the number of customers from already electrified settlements by 1.8 million. A three-phase grid extension program, involving 5,526 settlements, is expected to further increase the total number of customers connected by 2022 to more than 5 million (Innovation Energie Developpement, 2014). A successful electrification programme requires timely and sufficient investment in generation capacity and in network infrastructure. While the private sector is expected to contribute to invest in generation capacity via the PPP and SPP frameworks which have been established recently, it is not expected to engage in grid extension, which is seen as economically unprofitable (Ahlborg \& Hammar, 2014).

\section{Structural reform of the power sector}

The Tanzanian electricity sector is currently mired between two structural models: it has opened up toward private sector investments in generation, but transmission and distribution infrastructure investment is still the responsibility of TANESCO, the incumbent monopoly. Furthermore, although other vehicles have been created to channel private sector investment, they do not yet directly enter into transactions with the Tanzanian electricity consumers; TANESCO acts as the single buyer of

\footnotetext{
${ }^{14}$ Tariff was revised to $\$ 0.093 / \mathrm{kWh}$ in 1995 and $\$ 0.103 / \mathrm{kWh}$ in 1998 , but eroded again to $\$ 0.07 / \mathrm{kWh}$ by 2001 due to inflation (Diu, 2011).

${ }^{15}$ Tariff in 2005 was revised to $\$ 0.076 / \mathrm{kWh}$ under the management of NET Group Solutions (Diu, 2011).
} 

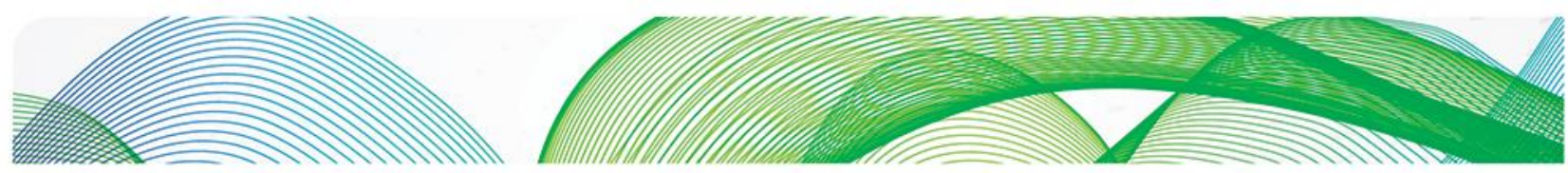

䢰

electricity, interfacing between private generation operators and all electricity consumers ${ }^{16}$. The integral tariff rate that is charged to all electricity consumers has been regulated by EWURA since 2006, while the payments that TANESCO makes to purchase power from private power generators have been privately negotiated in the form of PPAs ${ }^{17}$.

According to the Tanzanian Electricity Supply Industry Reform Strategy and Roadmap, the GoT has embarked on further reforming of the power sector from 2014 to 2025. Figures 14 and 15 show the current gas and power structure and the structure that Tanzania aspires to have in the future. The transition from the existing single buyer structure to the retail competition structure is to be conducted in stages:

- By 2015: ring-fencing (accounting unbundling) of generation, transmission, and distribution;

- By 2018: administrative unbundling of generation (Gx) from transmission and distribution and designation of an independent market operator; bulk off-takers able to purchase power directly from generators, after paying wheeling charges to the transmission owner;

- By 2021: administrative unbundling of distribution from transmission (Tx);

- By 2025: horizontal unbundling of distribution into several zonal companies (Dx);

By the end of the reform period, only the transmission and distribution tariffs are to be regulated (MEM, 2014). The wholesale price of power that bulk off-takers and retailers (who might or might not be distributors) are to be negotiated bilaterally through PPAs. The retail price is to be determined competitively by market forces.

Figure 14: Current structure of Tanzania's gas and power sectors (Based on personal communication with stakeholders)

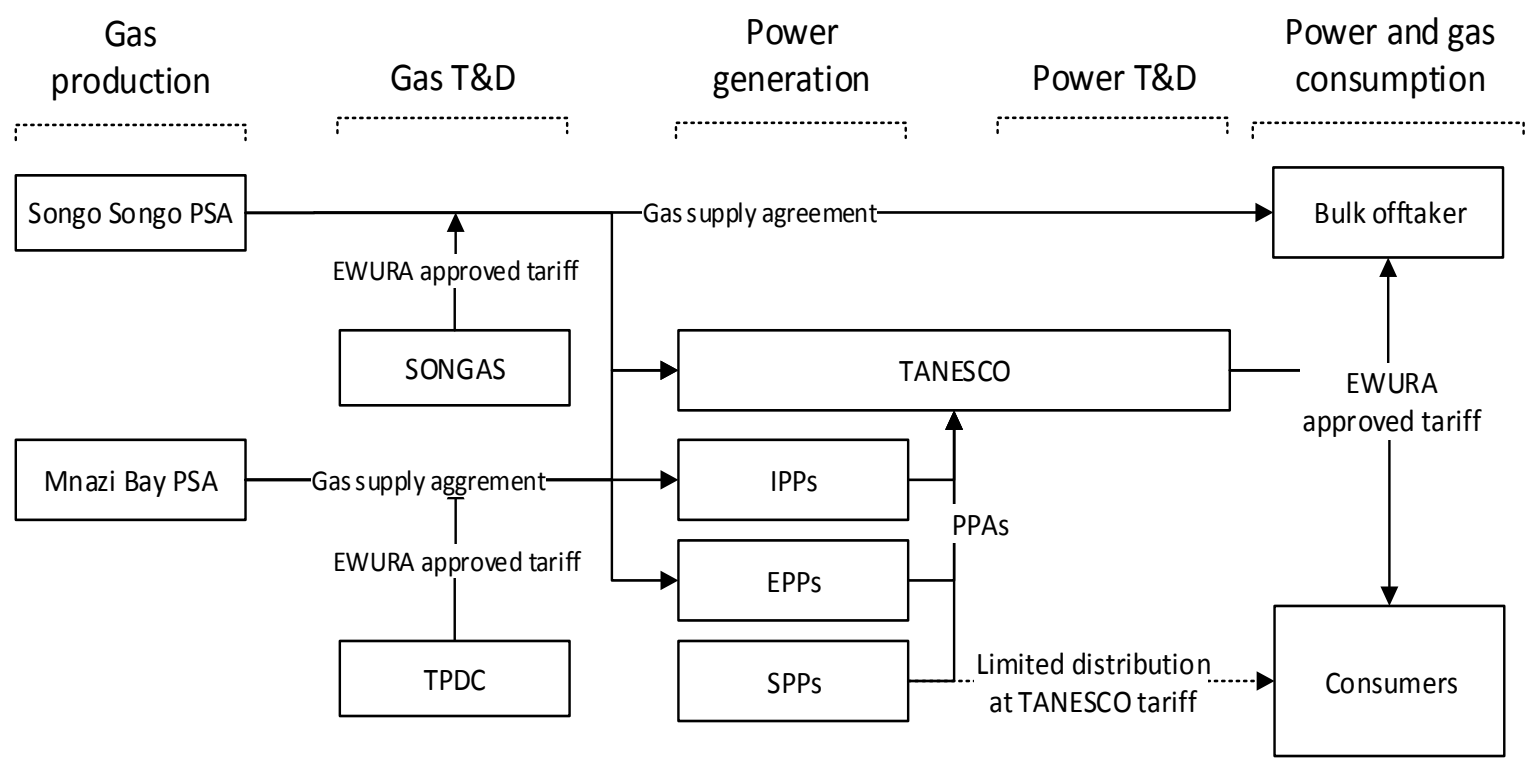

\footnotetext{
${ }^{16}$ Mwenga Hydro project, an SPP, is the only other owner of distribution and supply activity licence awarded by EWURA. It directly retails electricity to 15 remote and otherwise unserved villages.

${ }^{17}$ The Songas and IPTL PPAs were signed before EWURA existed. Recently, the EWURA has established and approved Model Power Purchase Agreements (Model PPAs) for projects above $10 \mathrm{MW}$ (Ngamlagosi, 2015).
} 

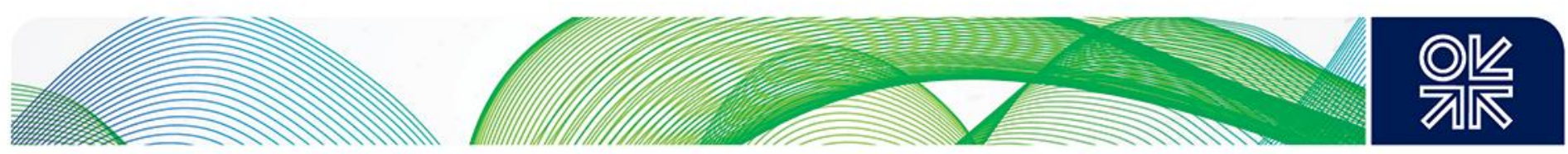

Figure 15: Desired structure of Tanzania's gas and power sectors (Adapted from MEM, 2014)

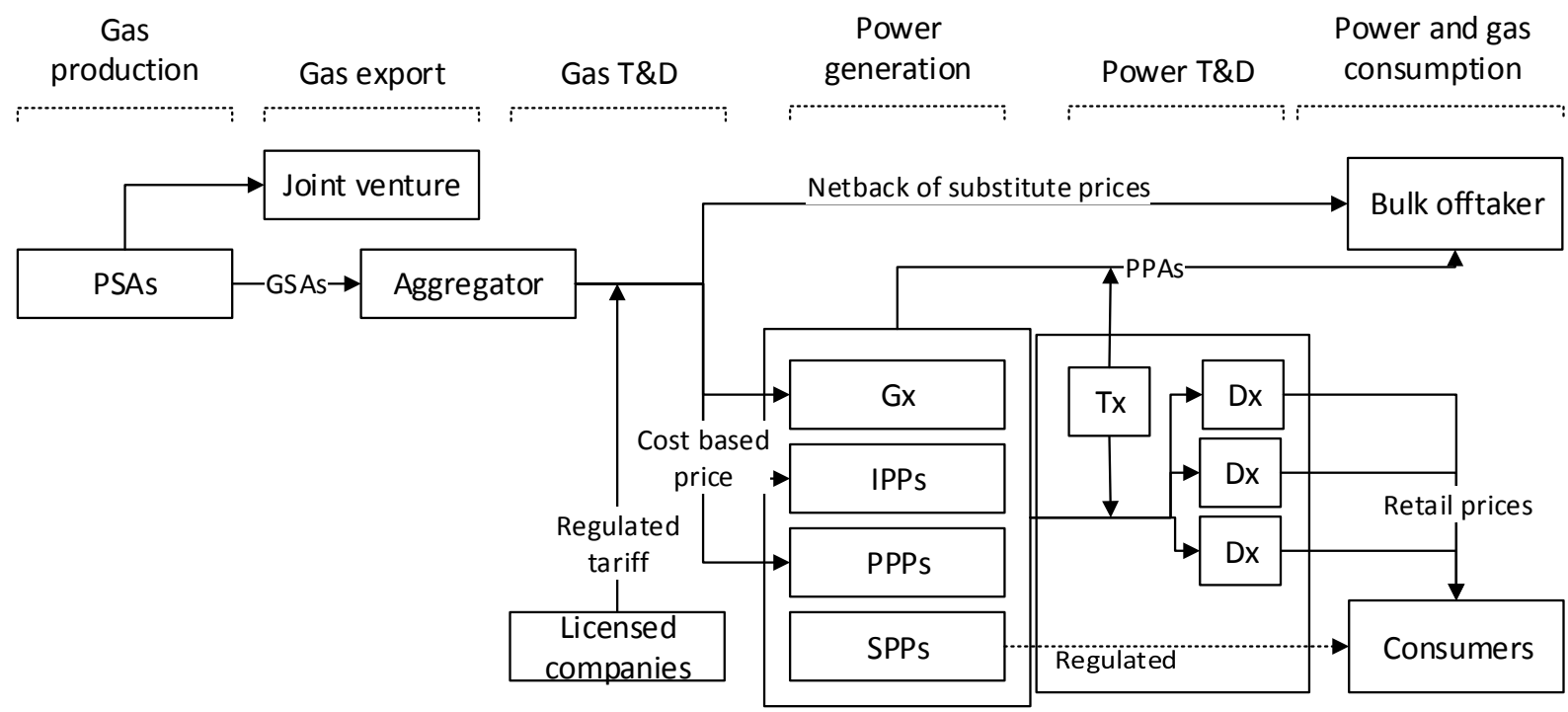

Based on communications with the President's Delivery Bureau in February 2016, the structural reform of the power sector has not yet reached its first milestone: the unbundling of generation, transmission, and distribution within TANESCO's accounts. It should be noted that the restructuring of the power industry in all countries is a highly path-dependent and political process, because it involves the redistribution of resources, control over key infrastructure, and the associated rents. In addition, consultations with multiple power sector stakeholders during the authors' research trip suggests that the prioritization of structural reform relative to other issues is different for different groups. Therefore, delayed implementation of the timeline proposed above is expected.

\section{Institutional framework for investment}

The long-term investment needed in the power sector for the period 2010 to 2035, as determined in PSMP 2012, is $\$ 40$ billion. Of this, the short-term investment needed between 2013 and 2017 is $\$ 11.4$ billion, of which $\$ 8.4$ billion is in generation capacity (Ministry of Energy and Minerals, 2013a).

It can be seen from Figure 16 that the strategy adopted is to rapidly develop gas-fired generation in the short-term (2014 to 2017), coal-fired generation in the mid-term (2017-19), and bring online hydro generation capacity in the long-term (2019 to 2025). The actively planned capacity of gas generation is $1,700 \mathrm{MW}$, which, in combination with existing gas-fired generation capacity of $736 \mathrm{MW}$, amounts to a total of 2,436 MW by 2017, if all planned power plants come online on time. If run at 70 per cent load (the average load factor of Tanzanian demand) and assuming a higher heating value (HHV) based efficiency of 40 per cent, supplying all these power plants will require a gas supply of 340 MMcf/day. ${ }^{18}$ Estimates from TANESCO, using different assumptions, forecast a 2018 demand of 475 MMcf/day (Wentworth Resources Limited, 2015b). The existing production capacity at Songo Songo

${ }^{18} \mathrm{HHV}$ used is $1,022.72 \mathrm{BTU} / \mathrm{CF}$, based on the quality of Songo Songo gas (White \&Case LLP, 2011). 

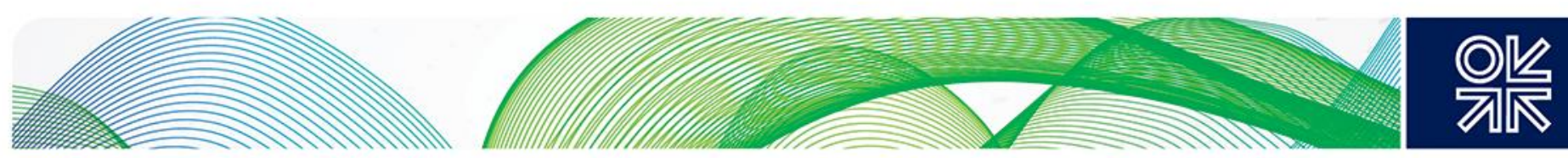

and Mnazi Bay is $102 \mathrm{MMcf} /$ day and $70 \mathrm{MMcf} /$ day, respectively, adding up to $172 \mathrm{MMcf} / \mathrm{day}$, falling short of the planned demand. Furthermore, the total near-shore reserve, estimated to be 2,147 Bcf, will only be able to support consumption by power generation plants at the planned rate for 17 years.

Figure 16: Generation mix of historical and planned installed capacity in 2013 (see Table 11 in the Appendix for detailed breakdown)
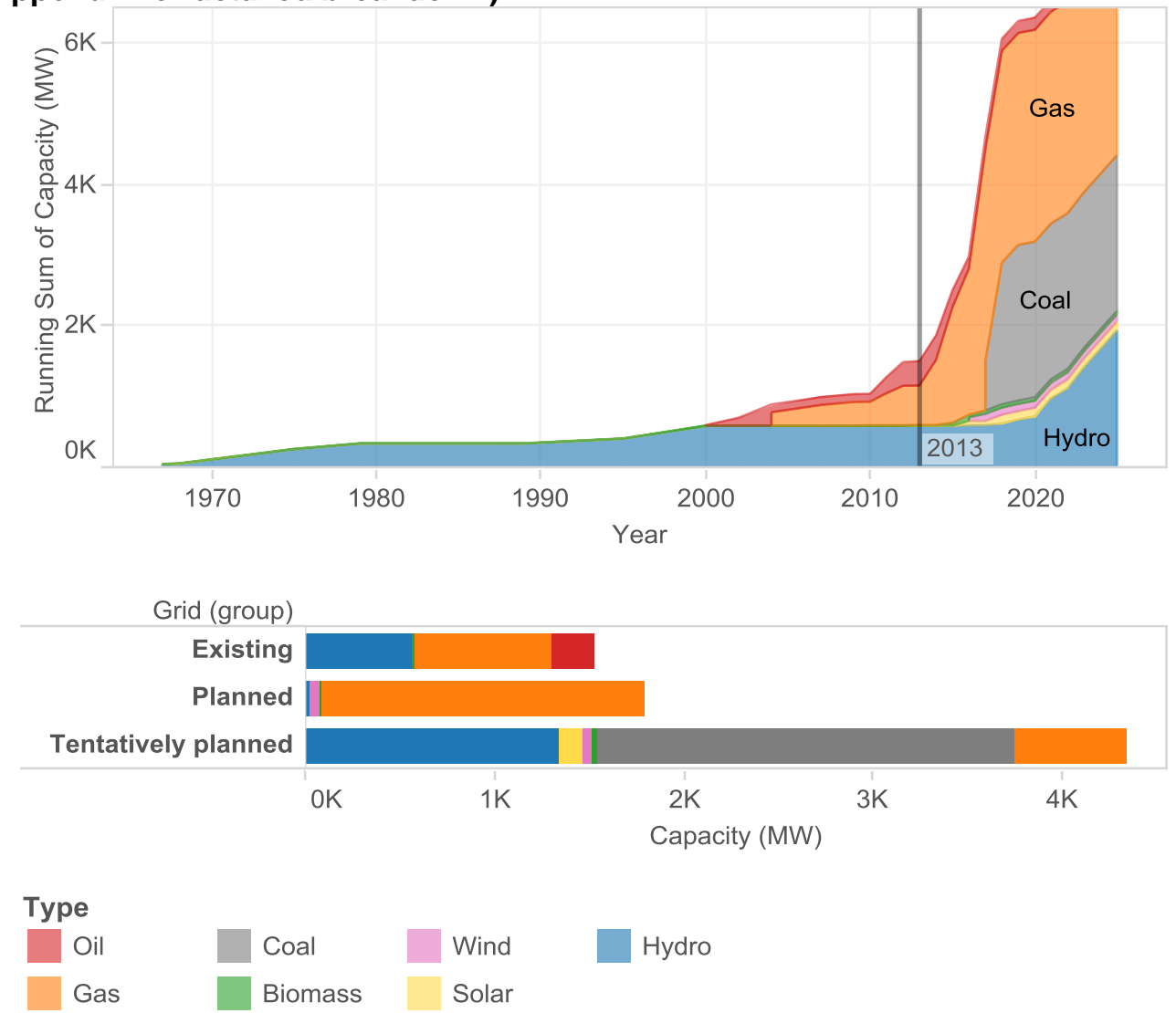

Given the above, the success of the investment plan presented above is not only conditional upon timely investment in generation capacity, but it is also dependent upon timely investment to double gas production and processing at Songo Songo and Mnazi Bay in the near term. In the long term (beyond 15 years), it is conditional upon the successful development of Tanzania's offshore gas resources for domestic use (unlikely independent of an export LNG project).

Based on the $\$ 120$ million investment made to expand production at Songo Songo from $92 \mathrm{MMcf} /$ day to $102 \mathrm{MMcf} /$ day, it can be estimated that the expansion needed (160 to $300 \mathrm{MMcf} /$ day) will require investment in the order of $\$ 2$ billion to $\$ 3.5$ billion (Simbeye, 2015). The existing gas transmission capacity between the production fields and the proposed locations for the power plants, the Mnazi Bay-Dar es Salaam pipeline, is reported to have a total capacity of $784 \mathrm{MMcf} /$ day, which is adequate and is not expected to require expansion in the near term (Wentworth Resources Limited, 2015a). In the long term, if the gas-fired plants are to supply Tanzania beyond 2035, then the off-shore reserves will also need to be developed by that time. The involvement of IOCs in providing investment and the technical skills needed to develop such resources is perceived to be of great importance, and it is 

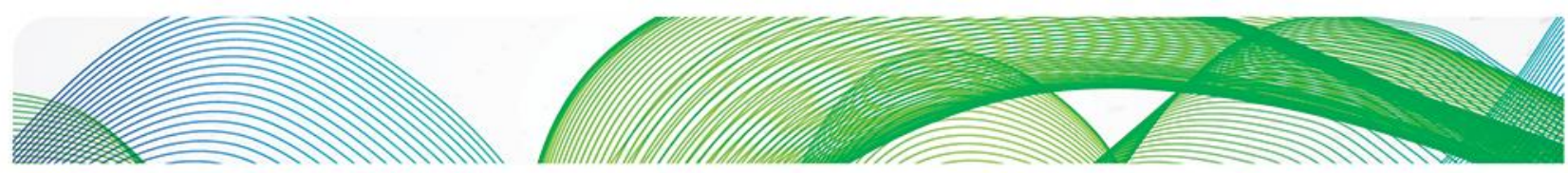

O는

conditional upon the development of the on-shore LNG export facility, reported to range between $\$ 20$ billion and $\$ 30$ billion (Ng'wanakilala, 2014). A proportion of the gas produced by the IOCs will be used to supply the domestic market under the domestic supply obligation contained in their PSAs. Given proven reserve of $55 \mathrm{Tcf}$, the planned gas-fired generation and planned $10 \mathrm{mtpa}$ LNG export facility (equivalent of $1,435 \mathrm{MMcf} /$ day) can be supported simultaneously at full capacity for approximatively 80 years. The investment needs required in the Tanzania power and gas sectors in the near term and long term are compared in Table 2.

Table 2: Comparison of investment needs in Tanzania's electricity and gas sectors

\begin{tabular}{lll}
\hline Sector & Near term (until 2018) & Long term (2018 to 2035) \\
\hline Electricity & $\$ 11.4$ billion & $\$ 30$ billion \\
\hline Gas & $\$ 2-3.6$ billion & $\$ 20-30$ billion \\
\hline
\end{tabular}

The following section presents and compares the institutional arrangements that exist to funnel in investment to electricity generation from the Tanzanian public, international financial institutions and donors, domestic and foreign private investors, and commercial banks. Their performance in bringing in investment is evaluated, after which the outlook for investment in the gas sector upstream to power generation is discussed.

\section{Vehicles of investment in the power sector}

In the power sector, five vehicles for investment exist: TANESCO, IPPs, EPPs, SPPs, and PPPs. Each vehicle is a different set of institutional arrangements which differ in the sources of funds that they access, the motivation driving investments, and the mechanisms through which investments are remunerated and risks shared. Through Figure 17 it can be observed that, historically, TANESCO has been the vehicle through which investments were made before the 2000s. From 2000-10, significant capacity of IPP-channeled investment came online, and since 2010, EPPs were the source of additional (and temporary) generation capacity, along with a small amount of SPP-backed generation capacity. TANESCO continued to be a channel for new generation investment after 2000. Also, it can be seen that the generation investment planned by the MEM is much more aggressive in 2015-19 than historical generation investment records.

Although direct investment by TANESCO is only one of the five investment vehicles, the other four are all deeply dependent on the state utility because the existing structure of the Tanzanian power structure makes TANESCO either the only power off-taker allowed (for IPPs, EPPs, and PPPs) or the most important power off-taker (SPPs). Consequently, all power generation projects procured not directly through TANESCO still need to sign Power Purchase Agreements (PPAs) with the utility. Therefore, TANESCO's financial health as well as its ability to structure and implement adequate PPAs is critical to power generation investment in Tanzania. 

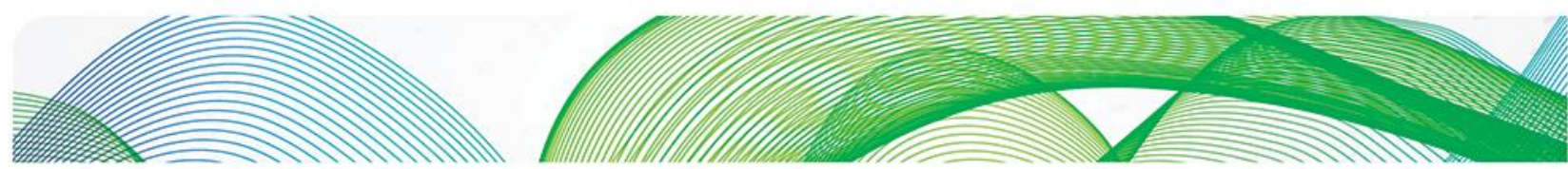

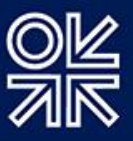

Figure 17: Modality of historical and planned installed capacity in 2013 (see Table 11 in the Appendix for detailed breakdown)

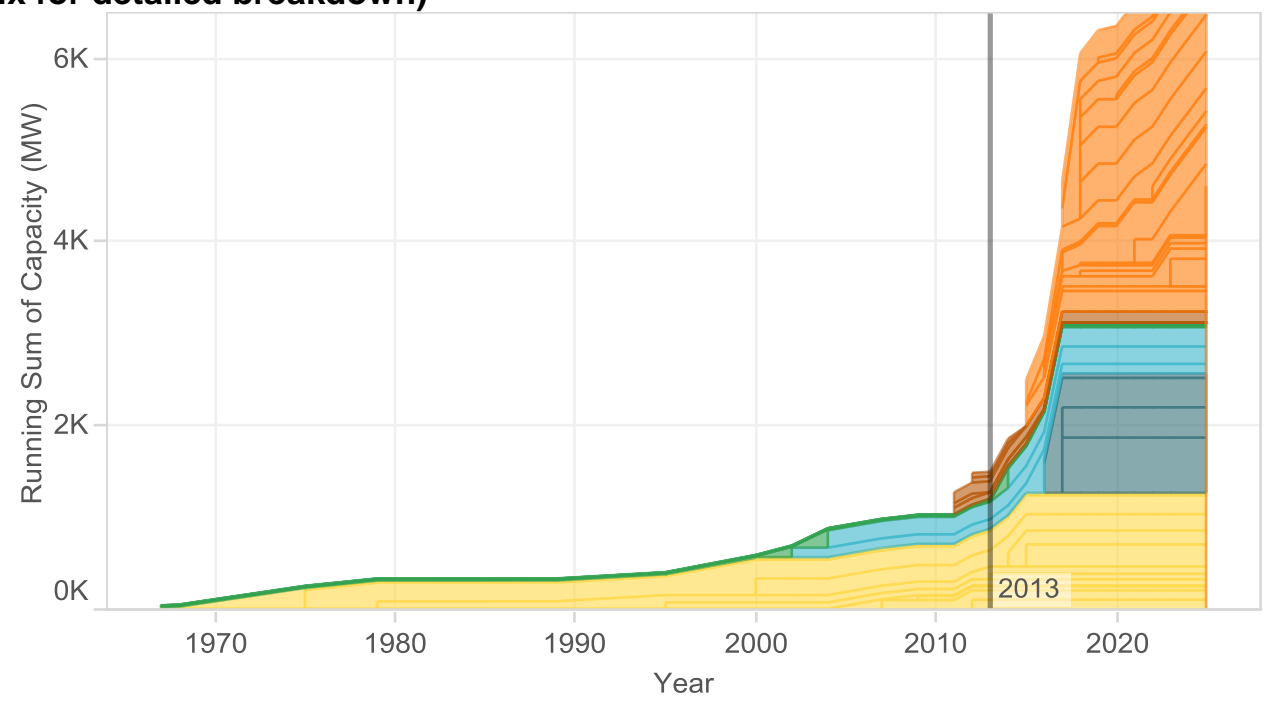

Power type

\begin{tabular}{|c|c|c|}
\hline Unknown & SPP & PPP \\
\hline EPP & IPP & TANESCO \\
\hline
\end{tabular}

\section{Investment via TANESCO}

Funds collected from Tanzanian ratepayers (via collected tariff revenue), taxpayers (via GoT advances toward capital share, other grants and subsidies), international financial institutions and donors (hereafter referred to as development partners, via basket funds and direct project funds), and commercial banks (via borrowings) flow into TANESCO (Table 3). Unless earmarked specific projects by sponsors, the funds collected typically go to pay for the utility's own operating expenses and loan repayments before they are directed toward investment. Given the role of TANESCO as the single buyer of all electricity from other generators, the funds that TANESCO collects also need to pay for power procured purchased from other power generators.

Since the 1990s, a gradual transition has occurred in the logic behind the operations and investments of TANESCO, from a state-led model to a market-led model (Ghanadan, 2009). This has had impact on the preferred sources of funds for TANESCO-based investments. Prior to 1990, the government and development partners were the only source of finance. Such development-oriented investors did not seek a commercial rate of return upon the investments made. Electricity pricing was perceived to be a channel for income redistribution, providing cross-subsidies to residential customers, small businesses, and local industries, fulfilling a social function. The ongoing electricity sector reform has a new vision for the sector: instead of financing investment in electricity sector via public means and provide it as a public service, the private sector is to play a more important role in financing new investment. It is hoped that domestic and foreign private investors seeking commercial returns upon investment will be shouldering the burden of financing investment, while ratepayers, the consumers of electricity, purchase electricity at a rate that reflects the cost of service provision and rewards private investment. 

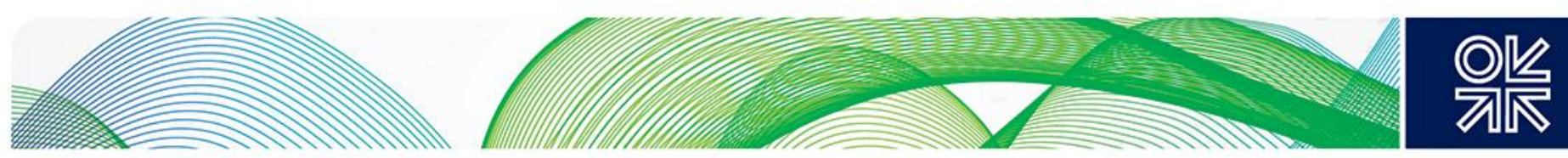

Table 3: Sources and sinks of funds for TANESCO

\begin{tabular}{|c|c|c|c|c|}
\hline From & As & To/From & As & To \\
\hline Ratepayers & $\begin{array}{l}\text { Revenue from tariff } \\
\text { collection }\end{array}$ & \multirow{11}{*}{ TANESCO } & Investment & \\
\hline \multirow{2}{*}{$\begin{array}{l}\text { Commercial } \\
\text { banks }\end{array}$} & Commercial loans & & Operating expenses & \\
\hline & Interests on deposits & & $\begin{array}{l}\text { Commercial loan } \\
\text { repayment }\end{array}$ & $\begin{array}{l}\text { Commercial } \\
\text { banks }\end{array}$ \\
\hline \multirow[t]{3}{*}{ GoT } & $\begin{array}{l}\text { Advance towards } \\
\text { share capital }\end{array}$ & & $\begin{array}{l}\text { Treasury borrowings } \\
\text { repayment }\end{array}$ & GoT \\
\hline & Treasury grants & & $\begin{array}{l}\text { Development loan } \\
\text { repayment }\end{array}$ & $\begin{array}{l}\text { Development } \\
\text { partners }\end{array}$ \\
\hline & $\begin{array}{l}\text { Treasuring } \\
\text { borrowings }\end{array}$ & & Income tax & GoT \\
\hline \multirow[t]{5}{*}{$\begin{array}{l}\text { Development } \\
\text { partners }\end{array}$} & $\begin{array}{l}\text { International } \\
\text { development grants }\end{array}$ & & $\begin{array}{l}\text { Value added tax } \\
\text { (VAT) for PPA }\end{array}$ & \\
\hline & Development loans & & PPA payments & IPP \\
\hline & & & PPA payments & PPP \\
\hline & & & PPA payments & EPP \\
\hline & & & PPA payments & SPP \\
\hline
\end{tabular}

Since 2012, prevailing poor hydrology has led to the use of emergency power plants and extensive use of TANESCO's own thermal generation plants, which has severely stressed its cash flow and is threatening its ability to deliver planed investment (and to fulfill its role as the counterparty to many PPAs). The impact of these events is evaluated through TANESCO's audited financial statements from the period 2007 to 2013.

Between 2007 and 2011, although TANESCO's balance sheet carried about 750 billion TZS) of accumulated losses, the sum was stable. However, between 2011 and 2013, accumulated losses increased from 800 to 1,450 billion TZS. During the entire period, the steady growth in assets of the company (more than 300 billion TZS per year) was accompanied by a proportional growth in equity, showing that the investments are financed by borrowings and grants with growing shares in the balance sheet (Figure 18). By 2013, 80 per cent of TANESCO's total assets was financed by liabilities - mostly consisting of borrowings, grants, and trade payables - which is an increase compared to 40 per cent in 2007. The decrease in the share of equity in TANESCO's balance sheet has two drivers: non-proportional growth in equity injection in the form of share capital or retained earnings, and the devaluation of existing equity by the increase of accumulated losses. 

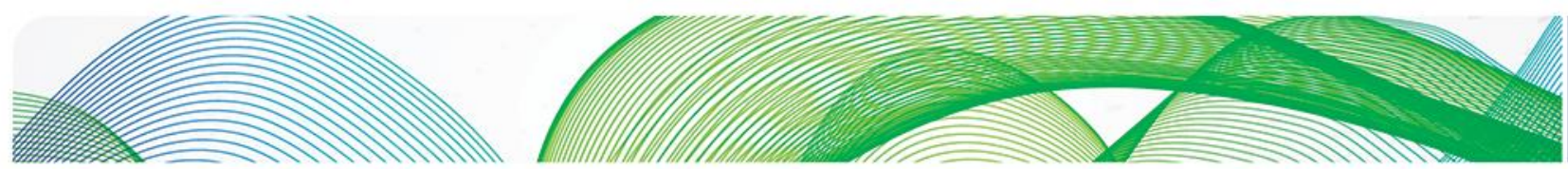

O倸

Figure 18: TANESCO balance sheet from 2007 to 2013 (Data source: TANESCO)

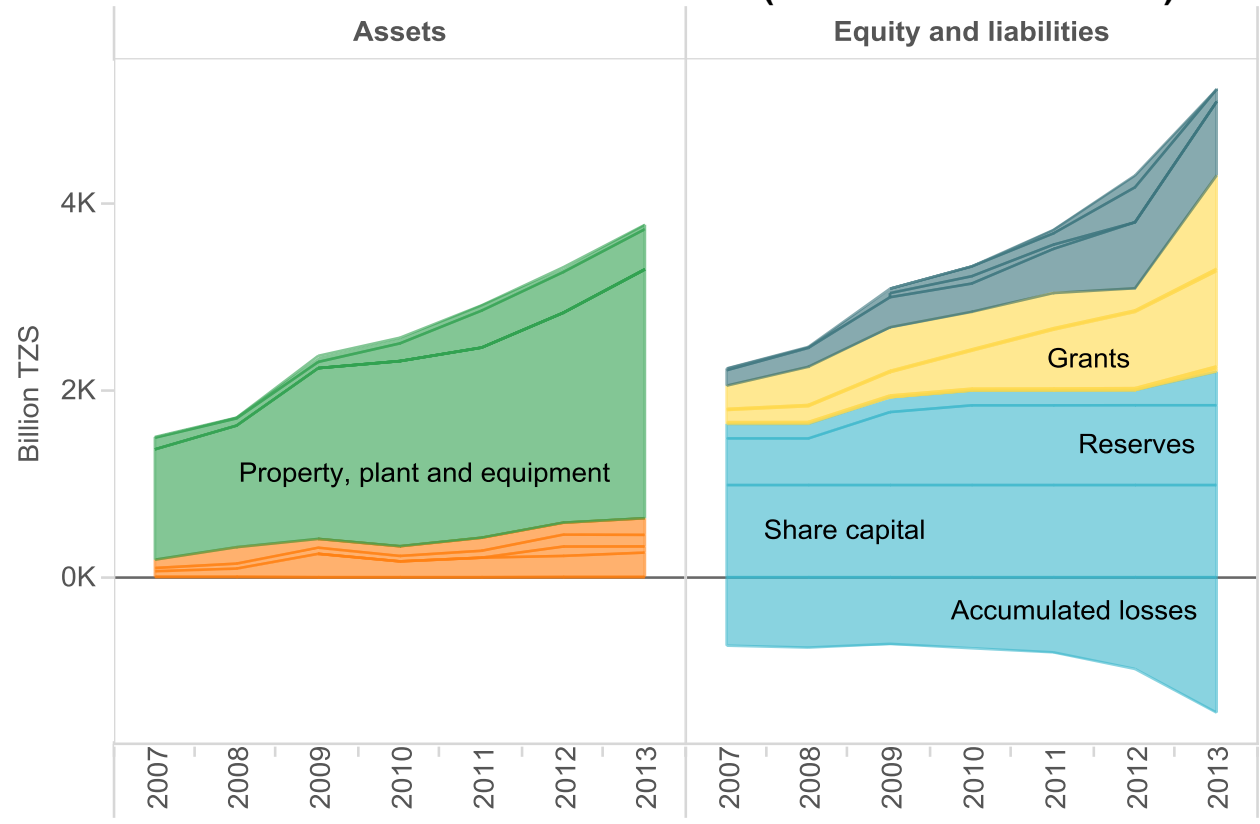

Sub-type

Non-current assets

Current liabilities

Capital and reserves

Current assets

Non-current liabilities

Furthermore, TANESCO's liquidity ratio (current assets/current liabilities) gradually worsened since 2009: starting from that year, its current assets have never been able to cover its current liabilities, consisting mostly of trade payables (Figure 19). This indicates the company's mounting inability to pay off its creditors and its likelihood of default. 

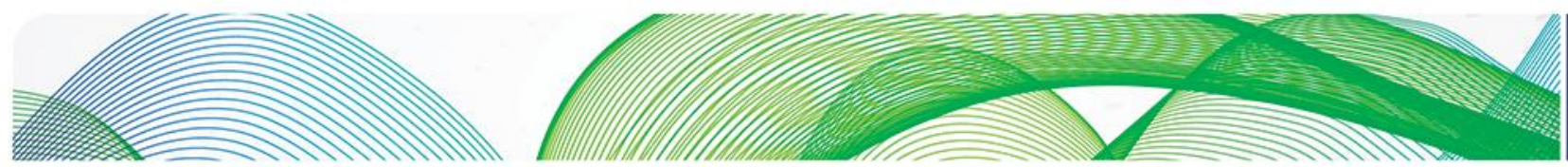

O倸

Figure 19: TANESCO's liquidity situation between 2007 and 2013 (Data source: TANESCO)

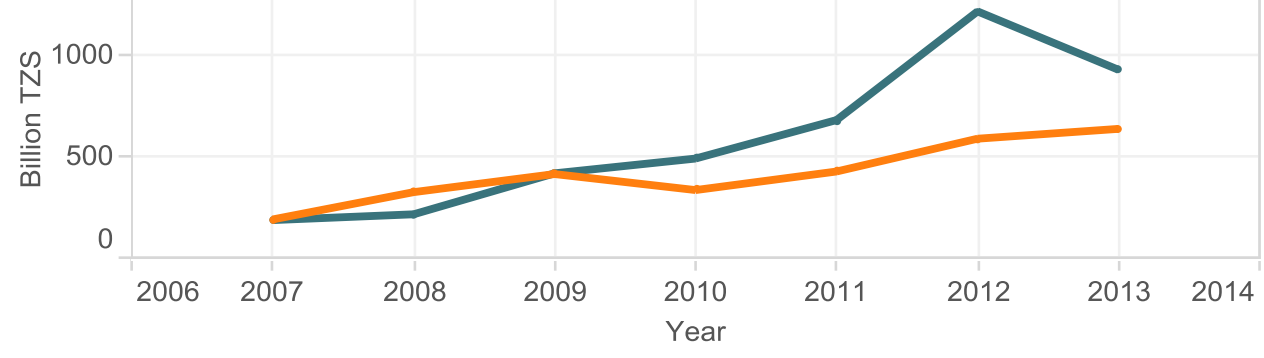

Sub-type Current assets $\quad$ Current liabilities

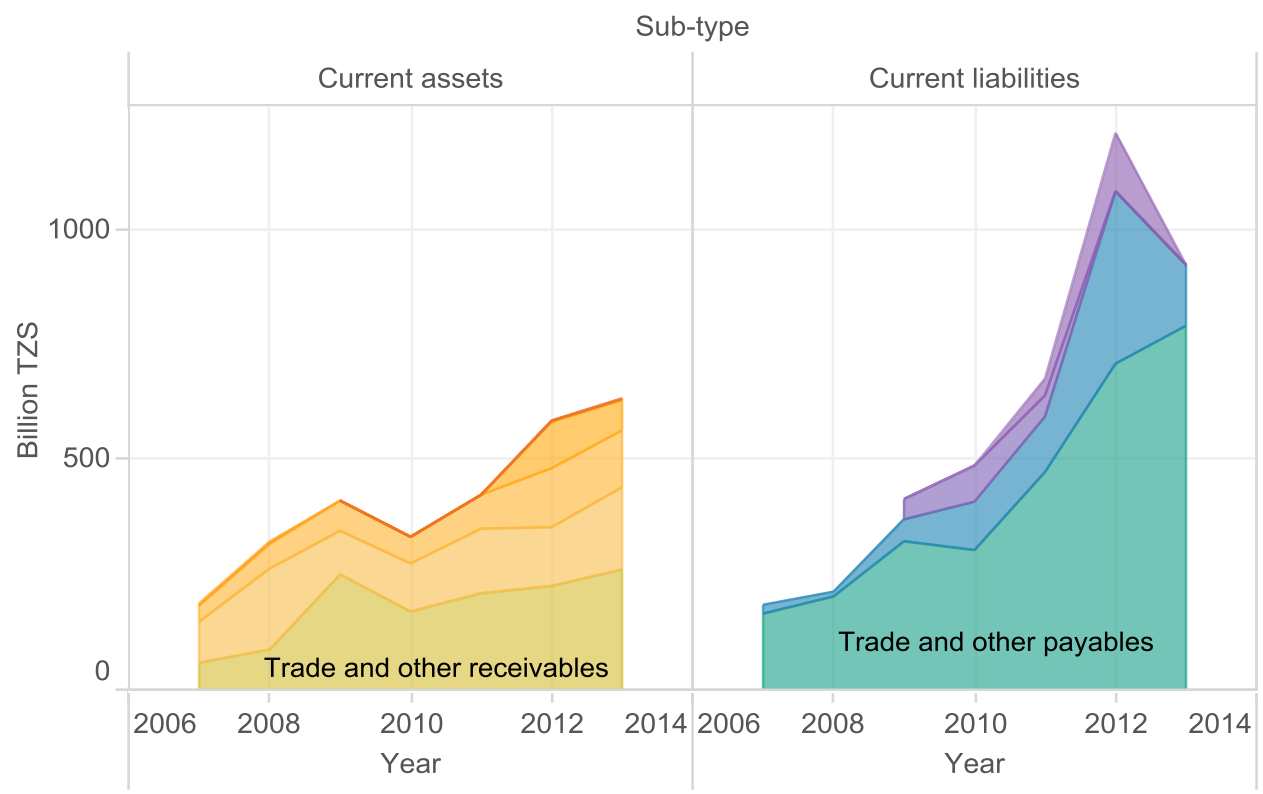

The account payable days and account receivable days of TANESCO are determined from its balance sheet and income statement. It can be seen that for the entire duration of the period studied, TANESCO's payable days have been higher than its receivable days (Figure 20). In other words, on average, TANESCO is taking longer to pay its creditors than TANESCO's customers are taking to pay their bills. As the receivable days have been lowering since 2011, inadequate revenue collection is not considered to be a main contributing factor to TANESCO's liquidity crisis. 

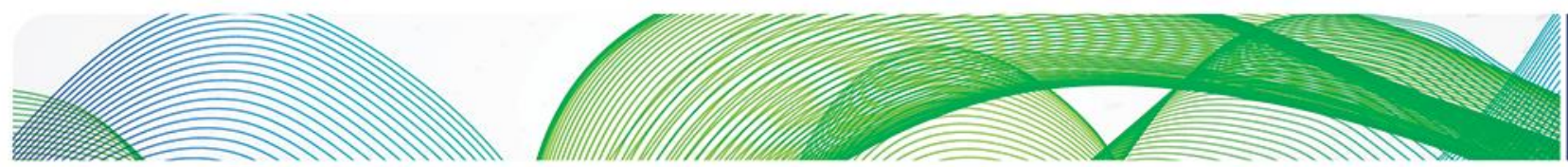

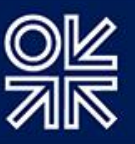

Figure 20: Comparison of TANESCO payable and receivable (Data source: TANESCO)

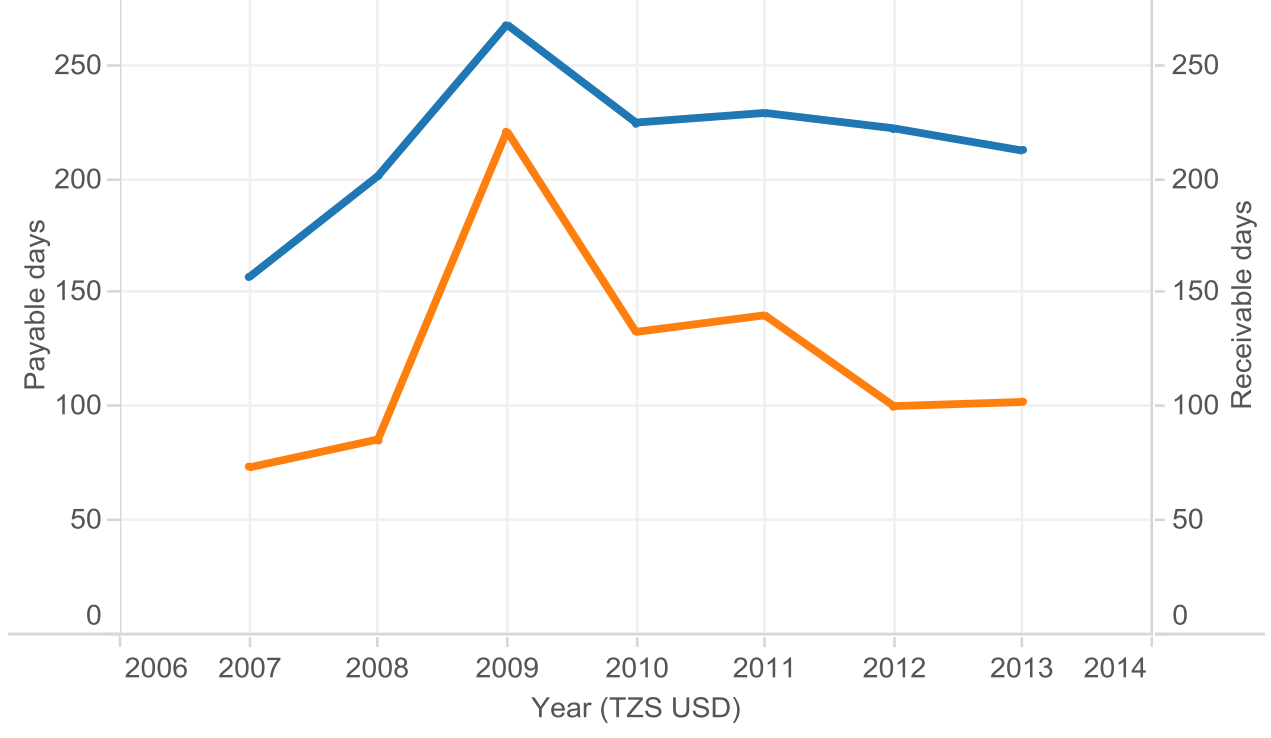

Measure Names

Payable days

Receivable days

According to the company's income statements, for the period 2007 to 2011, TANESCO's operating income was roughly in line with its operating expenses (net operating profit/loss smaller than 60 billion TZS). However, in 2012 and 2013 the net operating loss reported were 174 billion TZS and 387 billion TZS respectively, significantly above the previous trend (Figure 21). Comparing the change in individual items in the income statement to their value in 2007, it can be found that the most significant changes in 2012 and 2013 occurred in operating revenue and cost of sales. In 2013, operating revenue was 642 billion TZS above the 2007 figure, while the cost of sales was 1,033 billion higher than that of 2007. The cost of sales includes TANESCO's own generation and transmission, purchased electricity, distribution expenses, and depreciation. The tariff collected and other operating incomes such as government contribution were insufficient to cover the cost of sales, not to mention operating expenses and finance cost. Therefore, the net losses reported for 2012 and 2013 were 178 billion and 468 billion TZS respectively. 

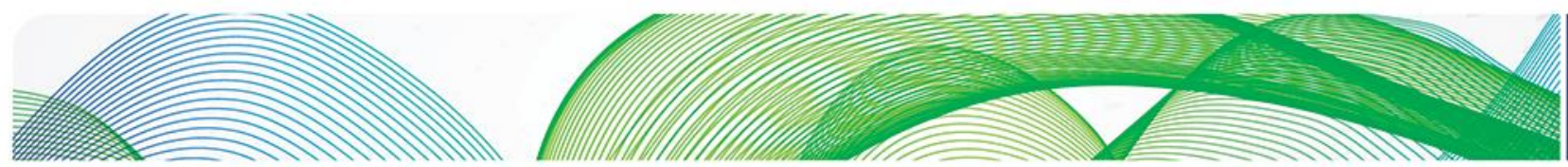

애존

Figure 21: TANESCO Income statement for 2013 (Data source: TANESCO financial statements)

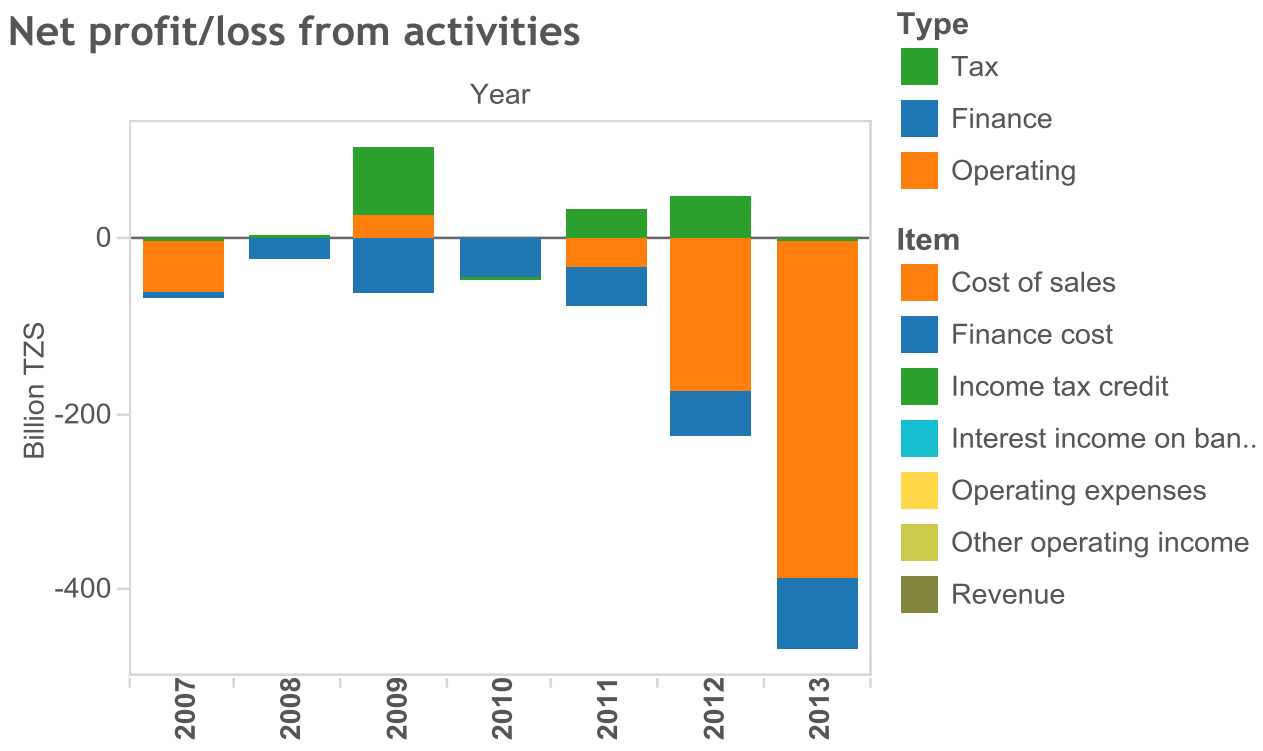

Change in item compared to 2007

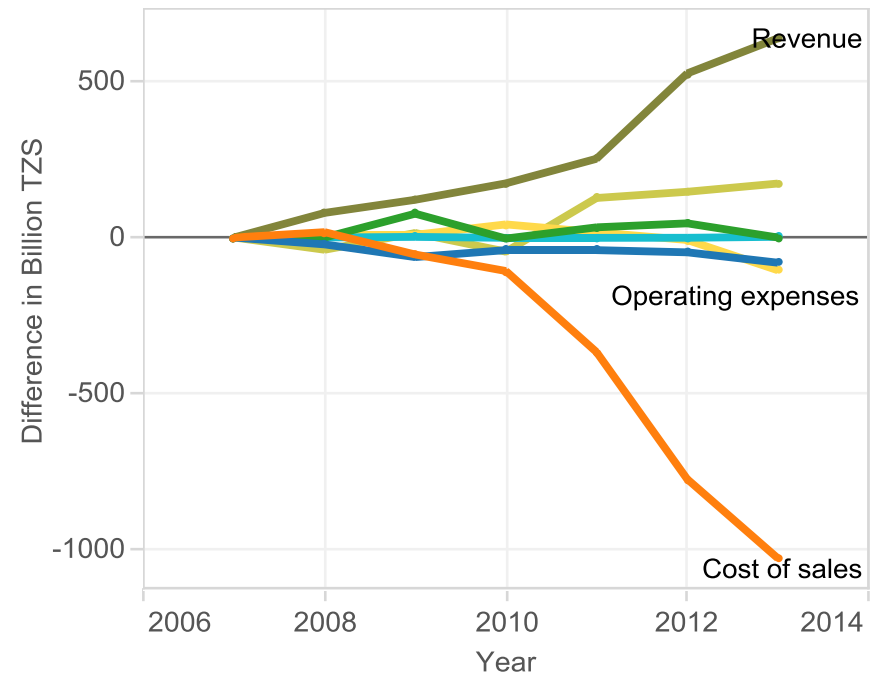

The evolution of cost of sales is examined in further detail in Figure 22. It is found that the greatest contributor to the 1,000 billion TZS rise in cost of sales was the purchased electricity component (570 billion TZS above its 2007 level, after decreasing during 2008-10). This is consistent with the evolution of hydro generating capacity available, subject to hydrological uncertainty (good hydrology in 2008-10, followed by bad hydrology in 2011-13). TANESCO's own generation and transmission costs also increased more rapidly after 2011 . On the other hand, the increase in revenue collected from different category of customers has not matched the increase in cost of sales. The extent to 

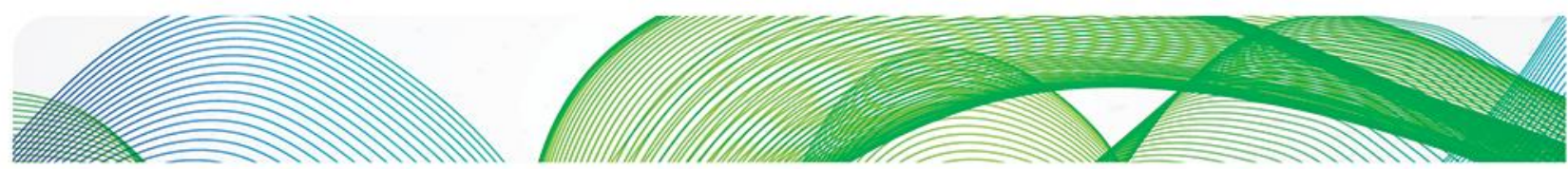

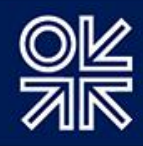

which these increases in costs are prudently incurred, and therefore eligible for cost recovery from the ratepayers, is the central topic of the section entitled 'Cost-reflective electricity tariff?'.

Figure 22: Breakdown of TANESCO cost of sales and revenue during 2007 - 2013 (Data source: TANESCO)

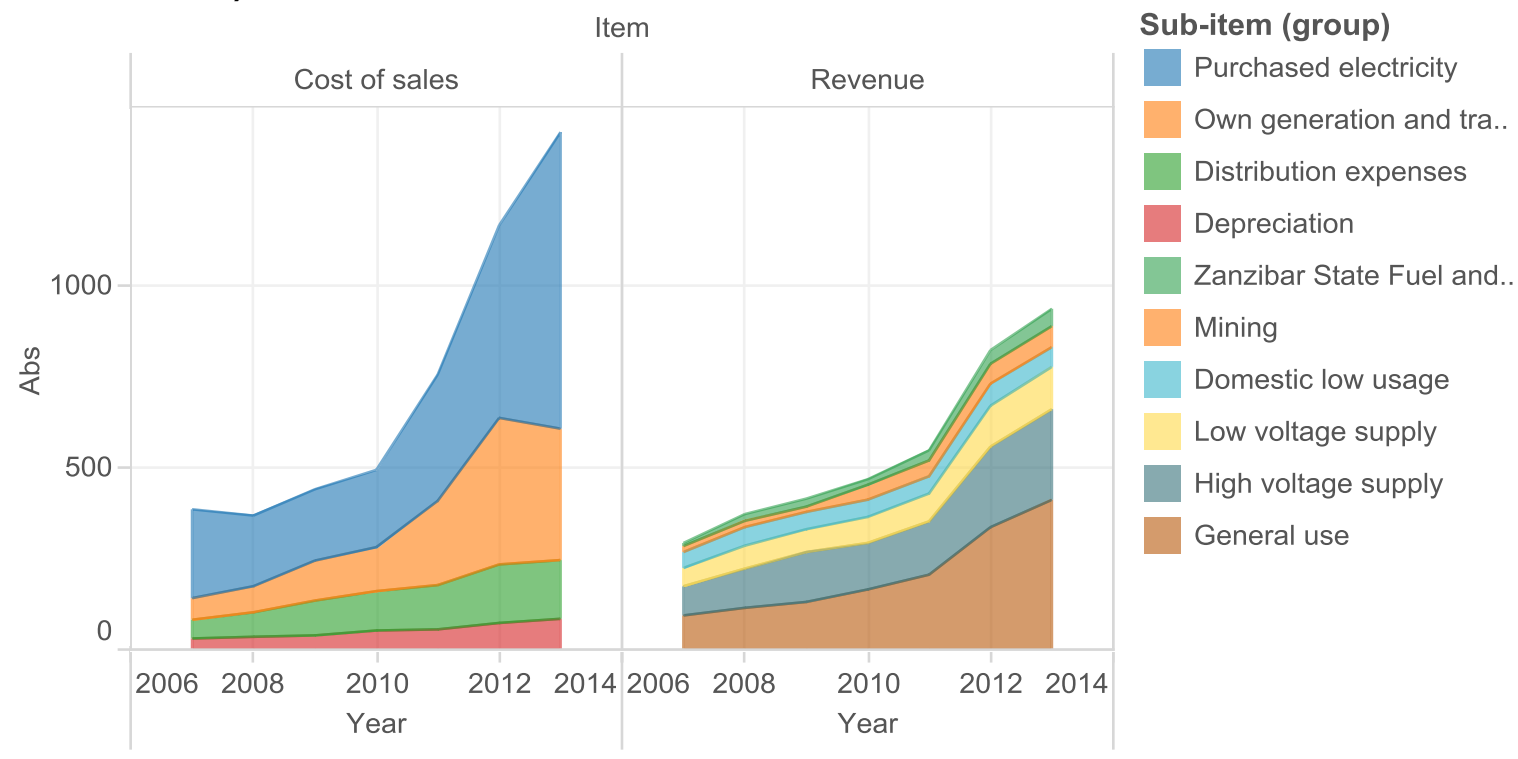

Change in item compared to 2007

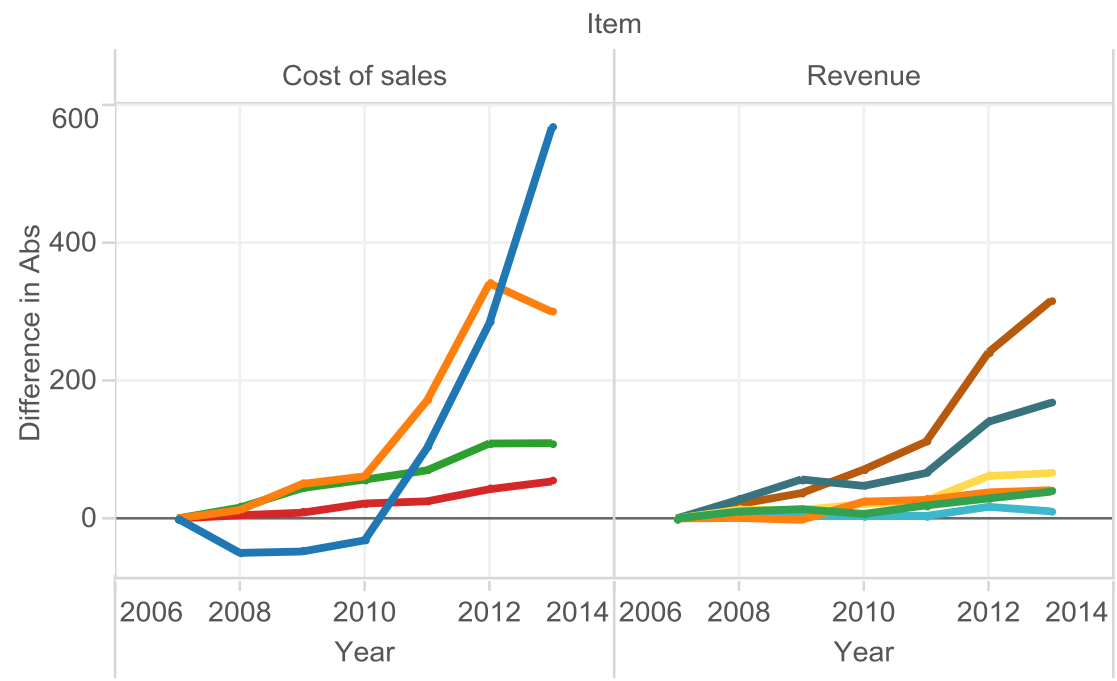

Between 2009 and 2011, TANESCO was able to sustain its investment cash flow and loan repayment using cash generated from operating activities and proceeds from borrowings and grants. However, by 2012, instead of being a source of positive cash flow, operating activities had turned into a burden which needed to be financed by more grants and borrowings (Figure 23). 

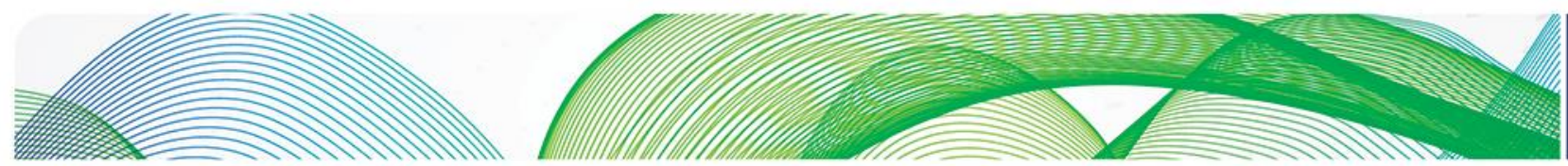

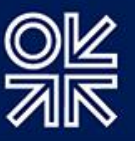

Figure 23: TANESCO net change in cash between 2007 and 2013 (Data source: TANESCO)

Year

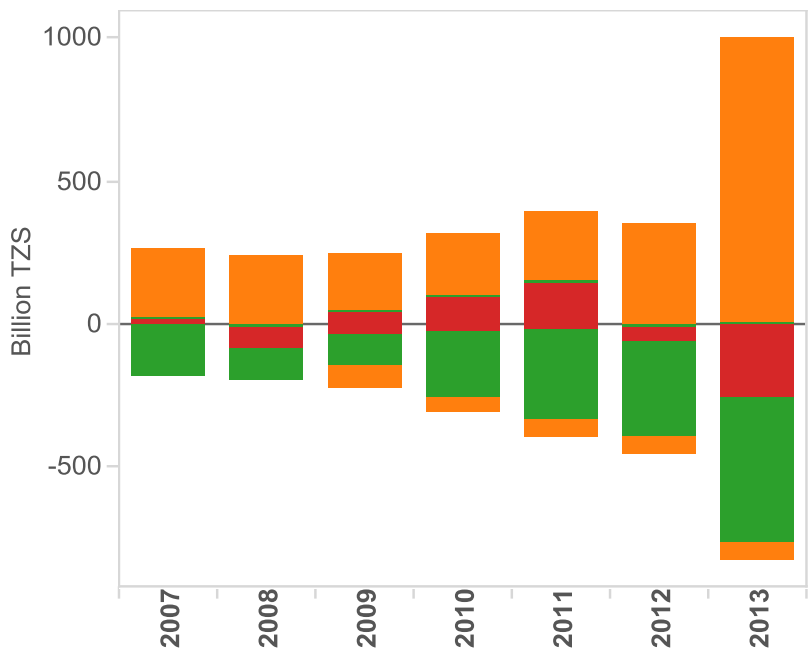

Type

Financing activities

Investing activities

Operating activities

The continuous depreciation of the Tanzanian shilling also had an adverse impact on financial sustainability of TANESCO and its ability to make reliable payments towards PPAs (Figure 24). PPAs with IPPs and EPPs are usually denominated in US dollars, while TANESCO collects power tariff denominated in Tanzanian shillings. Therefore, depreciation of the shilling results in a funding gap between TANESCO's payment obligations and its revenues. For instance, the costs of purchased electricity, when denominated in USD, increased by 49 per cent from 2010 to 2011. However, the same increase in costs, when converted to TZS (factor in the depreciation of the local currency in the same period of 9 per cent) reflects an annual increase of 63 per cent.

Figure 24: The value of one Tanzanian shilling in US cent

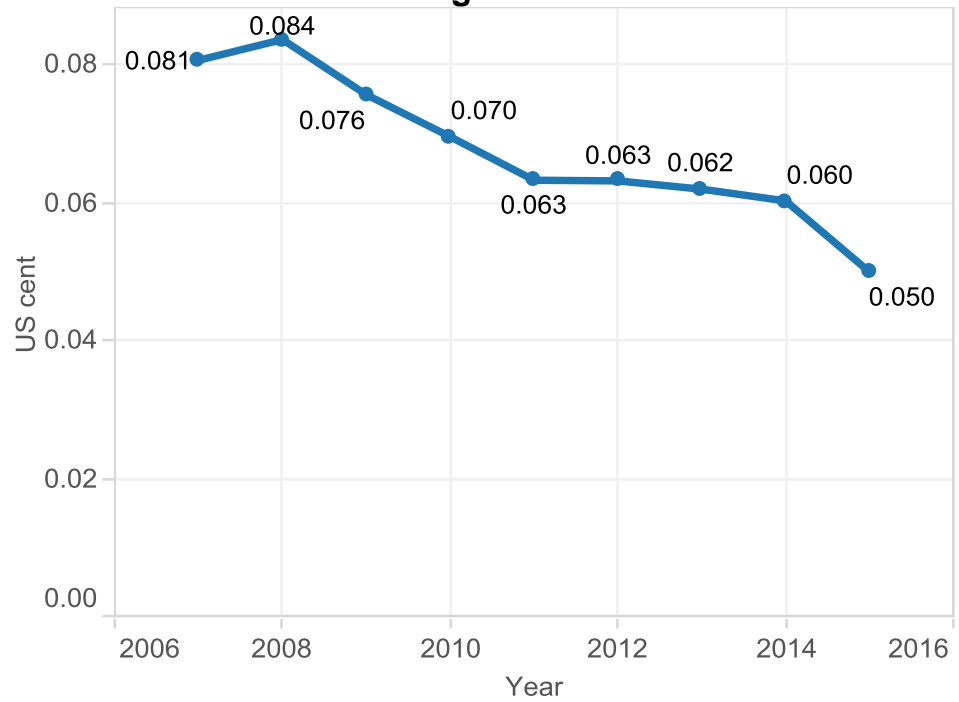

Despite TANESCO's deteriorating financial position (accumulating losses in its balance sheet and decreasing liquidity), it has directed about $\$ 1$ billion of its cash flow toward capital work in progress. 

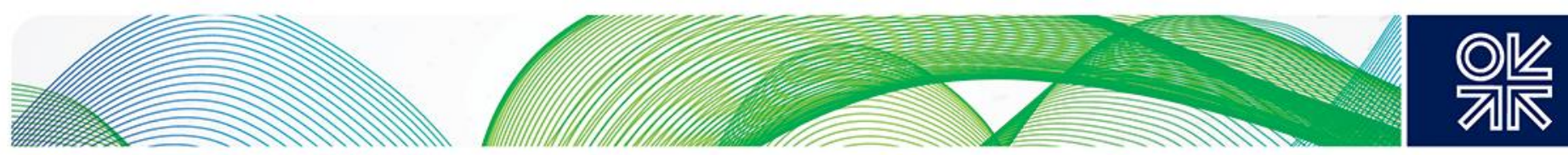

The investments undertaken by TANESCO in 2013 mainly focused on the extension of the transmission and distribution network, funded by the treasury and various development partners such as SIDA, ORET, and JICA. The generation capacity owned by TANESCO, commissioned in the last ten years or currently under development (Tegetea, Ubungo I and II, Mwanza, Kinyerezi I and II) has also been financed by the treasury and development partners. This demonstrates that, despite the wish of transitioning toward a market-led model to encourage private investments, TANESCO was still operating under a state-led model in 2013; acting as a state-owned utility making investment mostly financed by earmarked development and government loans/grants dedicated to particular projects. Yet, the vision for the power sector is one of financial sustainability, in which investment is financed by firms' operating activities and private sector capital rather than external funds, so that the national budget and development grants can be made available for other uses. This desired transition in investment dynamics depends on successfully mobilizing funds from the ratepayers, commercial banks, and domestic and foreign investors. At the same time, this transition should not compromise service quality, after all, continuous improvement in access and reliability to the provision of electricity is the ultimate goal that drives restructuring in the sector.

\section{Other vehicles}

In the remainder of this section, other types of investment vehicles which enable the participation of private sector capital in the generation segment are presented. Emphasis is put on their relationship with TANESCO, the only off-taker of all power generated (except for SPPs directly distributing to consumers) at the time of writing.

Investment via Independent Power Producers (IPPs)

From 1990, IPPs have been a channel for generation investments from domestic and foreign investors. In general, initial investments by IPPs are financed by private equity and commercial debt, but development loans from international financial institutions (sometimes on-lent through the government) are sometimes available, too. Once the generation plant is online and operating, the IPP recovers its investment with an added rate of return via payments received within the PPA lasting on average 15-20 years (Table 4).

Table 4: Sources and sinks of funds for IPPs

\begin{tabular}{|c|c|c|c|c|}
\hline From & As & To/From & as & To \\
\hline $\begin{array}{l}\text { Commercial } \\
\text { banks }\end{array}$ & Commercial loans & \multirow{5}{*}{ IPP } & Investment & \\
\hline Private equity & Share equity & & Operating costs & \\
\hline $\begin{array}{l}\text { Development } \\
\text { partners }\end{array}$ & Development loans & & $\begin{array}{l}\text { Commercial loan } \\
\text { repayment }\end{array}$ & $\begin{array}{l}\text { Commercial } \\
\text { banks }\end{array}$ \\
\hline GoT & On-lent loans & & Dividend & Private equity \\
\hline TANESCO & $\begin{array}{l}\text { Revenue from PPA } \\
\text { payments }\end{array}$ & & Income tax & GoT \\
\hline
\end{tabular}

Since the opening of the generation segment to private investors, Tanzania has only successfully engaged two IPPs: IPTL and Songas. The development of Songas began in 1993, when the MEM invited 16 companies to bid for the Songo Songo gas-to-electricity project. It received only two bids, one of which was submitted by OTC, a joint venture between Ocelot (known today as PAE) and TransCanada Pipelines (Gratwick et al., 2007). During the project's formalization in 1994, drought threatened the country's already tight power supply, leading to the proposal of the IPTL project, a 

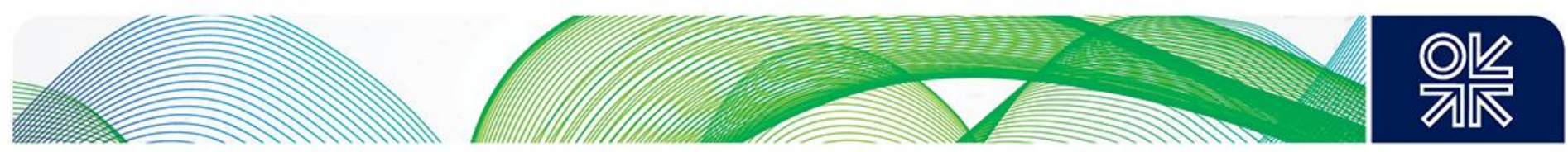

joint venture between Mechmar, a Malaysian firm, and VIP Engineering Limited, a Tanzanian firm, directly submitted to the GoT without tender. Financial closure for both IPPs took more than two years and required additional security arrangements and/or credit enhancements to be included in the PPAs.

IPTL, financed entirely with private sector equity and debt, was described as a South-South collaboration between Tanzania and Malaysia, and an alternative to the North-South donor-recipient model. The Malaysian company Mechmar, a boiler manufacturer, was already active in Tanzania, developing generator units for the Tanganyika Wattle Company. The Tanzanian partner, VIP, had no power sector experience, but it was experienced in promoting and negotiating for projects. IPTL's commercial debt from two Malaysian banks received an informal sovereign guarantee by the Malaysian government. In addition, an escrow account held by the Bank of Tanzania was created to act as a liquidity facility. It held between two and four months equivalent of capacity charges negotiated to support payment obligations of TANESCO, the off-taker. However, in the implementation of the project, a number of issues emerged and unravelled the relationship between IPTL and TANESCO, and that between the equity partners and the project's creditors.

In 1998, TANESCO and IPTL disagreed upon the costs of the project and the corresponding PPA tariff calculation. The arbitration process employed by the World Bank's International Centre for Settlement of Investment Disputes (ICSID) lasted until 2001. The tribunal refused TANESCO's request to rescind the PPA, but it also adjusted capacity charges from $\$ 3.6$ million to $\$ 2.6$ million per month to reflect the difference between cost estimates used in the PPA ( $\$ 163$ million) and the actually incurred costs ( $\$ 127$ million) ${ }^{19}$. Payments were made pursuant to the ICSID ruling, but in January 2007 TANESCO suspended capacity charge payments, claiming to have discovered that the equity contribution from VIP had been lower than the amount agreed upon in the PPA.

Meanwhile, in 2005, the Standard Chartered Bank Hong Kong (SCB HK) acquired the IPTL loan from its Malaysian creditor and inherited the right, title, and interests of IPTL's contracts, including the PPA. From October 2006 onwards, IPTL did not service its debt, and the SCB HK, vested with IPTL's contractual rights, requested TANESCO to pay it outstanding payments of $\$ 259$ million. This dispute led to another long arbitration by ICSID between 2011 and 2014. An escrow account was established after TANESCO stopped paying IPTL's capacity charges to collect the amount not disbursed. If TANESCO won the case, it would be refunded the unnecessary payments already paid, but if it lost, then the monies banked at the escrow account would go to IPTL. During the second arbitration, IPTL experienced turnover in its ownership: Pan African Power (PAP) bought the shares from Mechmar (via Piper Link) and VIP under contested circumstances, and took possession of the escrow account (The Citizen Investigative Team, 2014). The disposition of the $\$ 270$ million balance deposited in the escrow account was a source of a scandal that polarized the country, prompting international donors to withhold nearly $\$ 500$ million in general budget support to the country (Kabendera \& Anderson, 2014). Furthermore, although no longer a shareholder of IPTL, VIP sued SCB HK, Mechmar, and Wartsilar (manufacturer of the diesel engines) in 2015 for allegedly impeding conversion of the plant from oil to gas firing since 2005 (Sunday News Reporter, 2015).

Songas, a much less controversial project, required the use of an escrow account for its equity contribution to mitigate the risk of expropriation. It also required a liquidity facility that held the equivalent of four months of capacity charges to mitigate non-payment of PPA charges. In order to

\footnotetext{
${ }^{19}$ A portion of the costs incurred has not been deemed to have been prudently incurred by the tribunal, therefore it was disallowed as the basis of tariff calculation.
} 

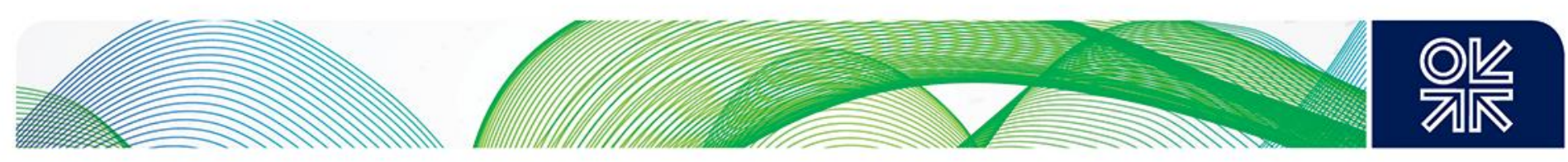

incentivize the use of equity by Songas prior to financial closure for debt fund, the MEM offered a nominal interest rate of 22 per cent on all equity disbursed during construction. This Allowance for Funds Used during Construction (AFUDC) was compounded annually until the project started to generate revenue (projected for 1999). During the first ICSID arbitration for IPTL, Songas was put on hold, yet the AFUDC for equity investment made between 1996-97 continued to be compounded until 2001. The buy-down of the AFUDC in 2003 resulted in $\$ 103$ million of additional cost born by the GoT (50 per cent), the escrow facility (40 per cent), and TANESCO (10 per cent).

Commercial loans were not available, therefore the debt financing for Songas followed an atypical model, with the GoT on-lending a World Bank International Development Association (IDA) credit together with a loan from the European Investment Bank (EIB). On the other hand, the two most important project partners, Ocelot and TransCanada, both arranged for the sale of its shares to AES, an American power generation and distribution company, on the grounds of strategic consolidation of assets, in 1999 and 2001, respectively. Later, during the global downturn in private power sector investment, following the Asian and Latin American financial crises and the Enron scandal, AES disposed of Songas and other assets while its stock price plummeted. The AES shares in Songas were then picked up by Globeleq (a spin-off of CDC) and the Dutch Development Company (FMO). Of the four original minor partners from development backgrounds (Tanzania Development Finance Company Limited [TDFL], International Finance Corporation [IFC], German Investment \& Development Company [DEG], and Commonwealth Development Corporation [CDC]), IFC, and DEG pulled out of Songas after the IPTL dispute became known.

Songas experienced delays in the delivery of gas from Songo Songo, reportedly due to the failure of a sub-contractor to deliver the gas infrastructure on time. Subsequent periods of non-availability occurred to accommodate expansion (originally planned, but postponed due to fast tracking of IPTL) and turbine failure. The penalties that Songas paid for non-availability of capacity as contracted did not match the additional costs incurred by TANESCO, due to the unfavourable hydrology necessitating the use of expensive fuel for generation. As part of the subsidiary loan agreement, signed between Songas and GoT for the on-lending of World Bank funds, if TANESCO fails to pay Songas the amount equivalent to the principal and interest, Songas is relieved of debt repayment for up to that amount. TANESCO had exercised this 'grace period' and did not pay full capacity charge to Songas between mid-2005 and mid-2006. In late 2015, Songas threatened to shut-down operations if TANESCO did not arrange to pay off arrears of $\$ 100$ million, claiming TANESCO payments had been erratic since early 2012 (Daily News Reporters, 2015).

Overall, IPPs did channel new sources of funds to investment in generation capacity in Tanzania's power sectors ( $\$ 393$ million in total, or $\$ 187$ million without the concessionary loan), but unexpected costs from these first experiences with PPAs, especially the disputes with IPTL, were high and tainted them negatively, generating controversial press coverage at home and abroad. Moreover, TANESCO's low liquidity threatens the operations of IPPs and negatively impact their willingness to invest. Given that the PPAs of both IPPs were negotiated before EWURA was established, and that future PPAs contracted are to be reviewed by the regulator, the performance of future IPPS is expected to improve, if the procurement process is completed as specified by EWURA.

The motivation that drove IPTL to invest in Tanzania's power sector is deeply entangled in multiple debates and hard to ascertain. On one hand, IPTL did channel commercial loans into generation investment which would not have been possible otherwise. On the other hand, the indirect costs of the IPTL case, in terms of negative public opinion and international reputation, is damaging to Tanzania's attractiveness as a country for investment. Development partners' grants were also frozen due to concerns with local governance and transparency issues. The delayed conversion of turbines 

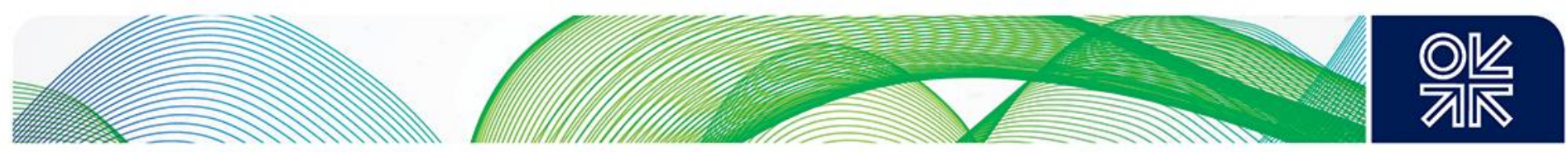

to run on natural gas is arguably another impact of the extended disputes between TANESCO, IPTL shareholders and IPTL's creditors. Its opportunity cost is high, given the important difference between the prices of these fuels. The two disputes between TANESCO and IPTL, regarding construction costs used to calculate PPA payments and IPTL partner's actual equity contribution, both have roots in the PPA's lack of a comprehensive outline of how such conflicts will be resolved. This points out the importance of due diligence before and after signing a PPA, assessing the project partner and monitoring project finance in a reliable way, and the importance of the PPA itself in attributing rewards and risks.

As for Songas, it is a government-initiated, development-oriented initiative that was passed on from commercial firms to development financial institutions as the project prospective evolved, and it was in large part financed by a concessionary development loan. It was inadvertently affected by the fasttracking of IPTL: the unexpected AFUDC buy-out and the postponement of originally planned capacity both incurred higher costs for TANESCO. This suggests that TANESCO, as the sole off-taker of all IPPs on behalf of all power consumers, should coordinate the contracting of the IPPs to minimize unintended impacts of one deal on another, through identification of risks that could propagate and their containment within individual PPAs (such as conditional compounding of AFUDC and penalty for project delays that is tied to actual costs incurred).

\section{Investment via Emergency Power Producers}

In terms of sources of funds channelled, EPPs are similar to IPPs. EPPs differ from other vehicles of investment, however, because the generation assets that they finance are not location specific. Emergency power, also known as temporary power, is typically provided via modular generation units mounted in shipping containers that can be relocated and assembled in a few weeks. Therefore, EPPs are willing to engage in shorter PPAs compared to IPPs, at relative higher charges, after which the private operator removes the power plant. The mobility of the investment involved thus makes EPPs less risk-averse than conventional power generator investors. Such specialized firms target emerging market countries with supply-demand shortfall (Aggreko, 2015a).

Since 2006, TANESCO has contracted emergency power from a number of multinational companies -Aggreko, APR Energy, and Symbion - as the government decided that the costs of procuring temporary emergency generation projects, about \$0.30-0.40 per kWh generated, were lower than that of load-shedding, estimated to be $\$ 1.1 / \mathrm{kWh}$ (Luhwago, 2011). While depending on EPPs in the short term, the government perceives EPPs as expensive service providers which should no longer be used when their contracts expire, if the needed capacity to ensure power supply has been procured through more permanent investment vehicles (MEM, 2014). The contracts that TANESCO signed with Aggreko and APR Energy in 2006 terminated by the end of 2008 (Kapika \& Eberhard, 2013). Aggreko was later contracted to operate two $50 \mathrm{MW}$ gas generator units between 2011 and 2013. Currently, $70 \mathrm{MW}$ from Aggreko is contracted, and the contract is subject to renewal every three months.

TANESCO's dealings with Richmond Development Corporation and its successor lasted from 2006 to 2013 , and they have been mired in controversy and legal disputes as in the IPTL case. The procurement of the Richmond/Dowans unit in 2006 took place under allegedly suspect circumstances that led to the November 2007 formation of a select investigative committee by the parliament. The investigation revealed that Richmond was a company without power generation experience. The tabling and debating of the committee report led to the resignation of the then prime minister and two cabinet members, subsequently leading to the dissolution of the entire cabinet (BBC News, 2008). The controversy was accompanied by the revoking of the power generation contract awarded to Richmond in February 2008. However, when Richmond was unable to deliver working generators 

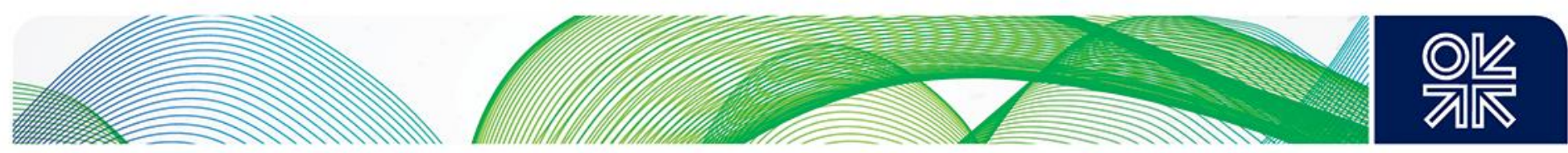

within the agreed period specified in the contract in late 2006, it assigned Dowans Holdings to undertake the responsibility of supplying electricity to TANESCO, associated with its two-year contract with a daily capacity charge of $\$ 150,000$. Dowans supplied electricity between 2007 and 2008, and it took TANESCO to the International Chamber of Commerce (ICC) for the termination of the contract and won. In 2013, Tanzania's Court of Appel upheld the ICC decision and ordered TANESCO to pay $\$ 77.5$ million to Dowans for breach of contract (Mwamunyange, 2013a). The Richmond/Dowans $120 \mathrm{MW}$ temporary gas-fired generators were acquired by Symbion in 2011 and have been since under Symbion's operation.

Again, as with Tanzania's experience with IPPs, the outcome of involvement of EPPs is mixed. EPPs do provide the much desired power generation capacity at relatively short notice, and they have PPAs which are relatively more flexible than those of IPPs, lasting 15-20 years, being signed for shorter terms, albeit at higher charges and in smaller quantities. Nevertheless, the lack of due diligence and non-compliance with formal procurement procedures could have extremely high political and financial costs that undermine the usefulness of EPP arrangements. In addition, the distribution of high EPP purchase costs between the government, ratepayers (which can be further disaggregated into different categories), and TANESCO is a major point for contention in the tariff setting process.

\section{Investment via Small Power Producers}

In contrast with Tanzania's experience with IPPs and EPPs, mainly taking place before the establishment of the independent regulator in 2006, the development of the SPP investment regulatory framework is driven by EWURA, whose work has been cited as an example for other countries developing SPP projects (Tenenbaum, Greacen, Siyambalapitiya, \& Knuckles, 2014). A framework consisting of standardized PPA, tariff methodology, process guidelines with standardized forms, process rules, and interconnection guidelines have been developed. The regulatory framework was developed consciously to streamline the process of developing SPPs by removing the need for negotiation and regulatory review of tariff, to reduce transaction and administrative costs. Under the EWURA regulations, an SPP is defined as a power plant that uses a renewable energy source with an export capacity of between $100 \mathrm{~kW}$ and $10 \mathrm{MW}$ (Mtepa, 2014). Due to their proximity to electricity consumers, and sometimes their position as the sole electricity source in a particular community, SPPs in Tanzania can bypass the monopoly of TANESCO in transmission and distribution and sell power directly to end-users. Based on the connectedness of the SPP and their off-taker, four main types of SPPs can be differentiated (Table 5). For cases 1 and 2, the tariff is based on the avoided costs for TANESCO in the main grid or the isolated mini-grid. For cases 3 and 4 , the developer must submit an application to EWURA for a cost-based tariff. SPPs connected to isolated mini-grids can convert to main-grid based PPAs upon interconnection with the national grid.

Table 5: Four basic types of SPPs (Kahyoza \& Greacen, 2011)

$$
\text { Location of SPP }
$$

\begin{tabular}{cll}
\hline Off-taker of generation & Connected to main grid & Connected to isolated mini-grid \\
\hline TANESCO & Case 1 & Case 2 \\
\hline End-users & Case 3 & Case 4 \\
\hline
\end{tabular}

Up to the time of writing, SPPs in operation have channelled investments from domestic industry (Tanganyika Planting Company, Tanganyika Wattle Company), development partners and the government (ACRA-CCS, African, Caribbean and Pacific - EU Energy Facility, REA), and private investors, with a total of $15 \mathrm{MW}$ net installed capacity. Potential SPPs that are in the works, if all realized, have a total capacity of $150 \mathrm{MW}$. Of the operational SPPs, most of the commercially driven initiatives have access to indigenous fuel sources (bagasse, wood chips, or coconut wood) which 

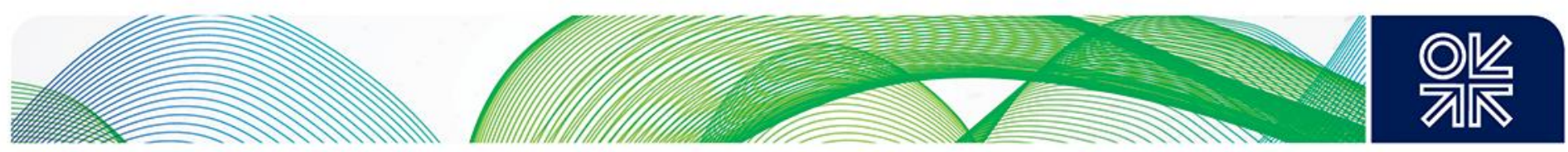

lead to important cost advantages for power generation. Other development-oriented initiatives, backed by development organizations, are rooted in community development which actively enhance the productive use of electricity, which include not only generation but also local distribution (Ahlborg \& Sjöstedt, 2015).

Despite Tanzania's world-class reputation in its practice of SPP regulation, the investment for generation capacity brought online via the SPP mechanism is low compared to other vehicles. Projects in the pipeline, if all realized and replenished at the current rate, could bring relief to demand unserved by other types of generation capacity, especially those in isolated areas expensive to be connected to the national grid. But, they need to overcome several challenges (Mtepa, 2014). Domestic private investors interested in SPPs face difficulties in securing long-term financing, because they are unable to provide the equity requirement of local banks (30 per cent of total investment). Business risks for SPPs are heightened in the isolated areas, given the uncertainty around grid expansion: the tariffs that they could charge and the number of customers that they could serve change once the isolated grid is connected to the main grid. SPP tariffs, when based on the cost avoided by TANESCO, are not sufficiently attractive for more expensive renewable technology such as wind and solar; thus, development interest has been mainly focused on waste biomass and hydro, a subset of allowed technologies. Also, as for IPPs, when power is sold to TANESCO, delay or non-payment is a possibility for SPPs given the utility's low liquidity.

\section{Investment via Public-Private Partnerships}

In recent years a new investment vehicle, PPPs - partnerships of government and one or more private sector companies - have been promoted by the MEM in its roadmap for the electricity sector (MEM, 2014). Traditionally, PPPs refer to long-term contracts between a public-sector party and privatesector party for the design, construction, financing, and operation of public infrastructure by the private-sector party, with payments over the life of the contract made directly by the public sector or users of the facility, and with the facility remaining or reverting to public-sector ownership at the end of the contract (Yescombe, 2007). However, according to interviews with the President's Delivery Bureau, PPPs in Tanzania's power sector mainly refer to joint ventures between the government (via TANESCO) and private companies in generation. PPP projects are now sourced in two ways: open bidding through the PPP units in the Ministry of Finance, and direct negotiation with ready investors (closed tender) (NKRA Energy, 2015). At the time of writing, there are four planned PPP projects, totalling 1,300 MW of generation capacity (Kinyerezi III and IV, Mtwara, and Geo Wind), or 2,280 $\mathrm{MW}$, if all phases of these generation projects are realized. It is the most ambitious of any investment vehicle to date, but because none of the planned PPPs have started construction, details about the nature of the long-term contract between TANESCO, the public-sector actor, and its private partners are not available.

Kinyerezi III, IV, and Geo Wind are all financed by Chinese institutions such as the Export-Import Bank of China, Poly Technologies ${ }^{20}$, and China Power Investment Corporation. Mtwara, a potential PPP with Symbion, is still in the stage of feasibility studies and has not reached financial close. The dominance of Chinese finance in new large-scale power generation projects in Tanzania is not coincidental, it is part of increasing Chinese engagement concerned with natural resources extraction, infrastructure development, and manufacturing all over Africa. It is estimated by the chief country risk

\footnotetext{
${ }^{20}$ Poly Technologies is a subsidiary of China Poly Group, a central government-administered state enterprise originally founded by the People's Liberation Army, later transferred to the State-owned Assets Supervision and Administration Commission.
} 

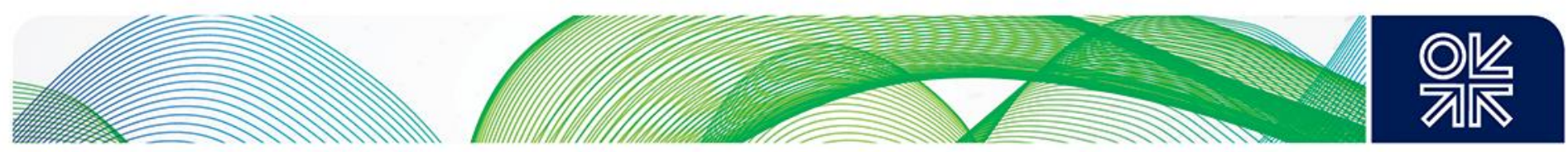

analyst of the Export-Import Bank of China (Exim Bank) that China will have provided the whole continent with $\$ 1$ trillion in direct investment, soft loans, and commercial loans by 2025 (Shih, 2013).

The Chinese approach, unlike traditional development assistance, actively mixes development finance and aid in order to maximize feasibility and flexibility of Chinese project to circumstances in the recipient country (Sun, 2014). In return, China's aid/finance is usually tied to Chinese companies and its loans are backed by natural resources from the recipient country. In practice, the disbursement of tranches of Exim Bank funding could be tied to Chinese company's acquisition of stake in local resources. A RAND Corporation paper has found that Chinese engagement in Africa has contributed to the development of critically needed infrastructure and economic growth, especially in areas where other investors (international financial institutions, other government and foreign investors) have been unwilling to engage, under terms that other investors are reluctant to provide (Hanauer \& Morris, 2014). However, Chinese engagement has also reinforced many countries' dependence on raw materials and unskilled labour and contributed to high levels of debt, economically nonviable decisions, and official corruption.

In comparison, after directly providing grants for large hydroelectric projects in the late $20^{\text {th }}$ century, development assistance from OECD countries is now focused on promoting local ownership and leadership to achieve national development, good governance, transparency, accountability, and capacity building. For example, Millennium Challenge Corporation (MCC), an independent US foreign aid agency, is in the process of negotiating a $\$ 472$ million compact with Tanzania which ties distribution network grant disbursement to the GoT's progress in reforming its electricity sector. The new compact also contains grants directly allocated to the unbundling process itself, incentivizing process change rather than unconditionally financing infrastructure projects (MCC, personal communication, 2016).

The generation capacity, financed by China, is expected to contribute positively to the electricity supply-demand gap in Tanzania once commissioned. Nevertheless, previous experiences with IPPs and EPPs have shown complex investment vehicles such as PPPs are vulnerable to corrupt procurement and negotiation processes. Development partners' push for capacity building could encourage the development of transparent procedures for the sourcing and negotiation of PPP projects. However, Gray, in her study of political economy of grand corruption in Tanzania, points out that the underlying distribution of power in Tanzania (not always aligned with the formal structure of institution) is what drives corruption related to off-budget expenditures of the state (TANESCO-led investment and PPAs involving TANESCO included) and what prevents curbing of such corruption cases (Gray, 2015). Therefore, ultimately, the likelihood of curbing corruption in Tanzania's power sector investments, so that they contribute positively to the country's socio-economic transformation, is dependent on the distribution of economic and political power in the country, stable but not immune from emerging social forces.

\section{Outlook for investment in the gas sector}

As previously established, the availability of natural gas as a generation fuel for all planned gas-fired power plants will require expansion of gas production capacity in the near and long term. This section discusses the outlook for investment in the Tanzanian gas sector.

The national oil company, Tanzania Petroleum Development Corporation (TPDC), does not invest significantly in exploration or development of oil and gas resources independently. From 2010 to 2012 , the annual cash flow directed toward capital work in progress is less than $\$ 1$ million per year. In 2013 , however, financed by a $\$ 1.2$ billion long-term loan obtained from the Export-Import Bank of 

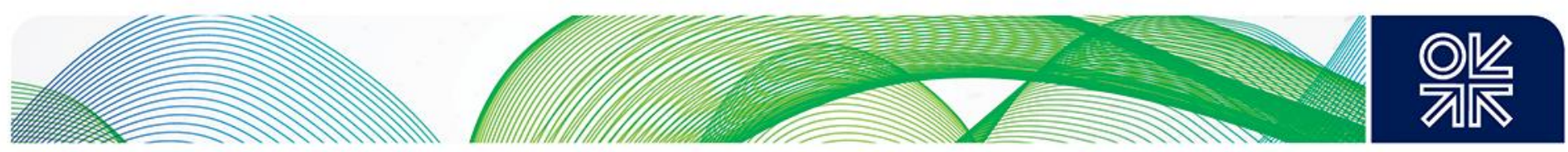

China, TPDC invested in the Mtwara-Dar es Salaam gas pipeline, which was commissioned in 2015. The pipeline relieves the country's need for gas transmission capacity in the medium term.

All other entities wishing to invest in the Tanzanian gas production capacity must do so via a PSA signed with GoT and TPDC. Under the tripartite PSA, the state (as the owner of oil and gas resources) licences the exploration and development of resources in a particular area by TPDC, which engages the third-party company as a contractor to provide technical services and financing for petroleum operations. The distribution of rewards and risks among the partners (represented in the PSA) and external factors - such as the geological features of the area, the general investment climate, and the domestic and global market context - are thought to influence private (and mostly foreign) investment in the sector (Pedersen \& Bofin, 2015).

In the near term, the necessary expansion of near-shore gas production, estimated to be 180-300 MMcf/day, can only be undertaken by the current operators engaged in PSAs. PAE, the operator of Songo Songo, has announced plans to increase gas production there from $92 \mathrm{MMcf} /$ day to 190 MMcf/day. It hopes to finance the $\$ 160$ million expansion spending through a loan from the IFC. In 2015 , a $\$ 60$ million loan was granted by the IFC for the first phase of Songo Songo production capacity expansion. The company expressed that subsequent investment will be conditional upon:

i) the agreement on commercial terms with TPDC, the expected gas aggregator, or other buyers regarding the sale of incremental gas volumes;

ii) TANESCO receivables being brought up to date, through guarantees or other arrangements to payment satisfactory to the company ${ }^{21}$;

iii) the establishment of payment guarantees with multi-lateral lending agencies to secure future receipts under any contracts with government entities; and

iv) future arrangements of finance (Orca Exploration Group Inc., 2015).

The management of Orca, PAE's parent company, has also expressed concerns over the potential negative effect on its rights under the PSA as a result of the new National Natural Gas Policy. As for the operators of Mnazi Bay, Wentworth Resources and Maurel \& Prom, their gas resources were effectively stranded prior to the commissioning of the Mtwara-Dar es Salaam pipeline. The partners only signed their first Gas Sales Agreement with TPDC in September 2014, which is for up to 130 MMcf/day of gas delivery for 17 years. Therefore, the near-term plan is only to expand current capacity of $80 \mathrm{MMcf} /$ day to $130 \mathrm{MMcf} /$ day.

In the long term, the sustainability of gas-fired generation in Tanzania requires the development of off-shore natural gas resources, which is dependent on the involvement of IOCs, given the success of any project requires their technical expertise and financial backing. The participation of IOCS, in turn, depends on the investment prospects for the LNG export facility. The potential investors in question (BG, Statoil, ExxonMobil, and Ophir), have not yet made a final investment decision. Because the export of LNG is intended to supply the global LNG market, investment decisions of the IOCs will depend not only on Tanzania's domestic context (attractiveness of PSAs, general investment climate, geological conditions etc.), but also on developments in the international gas market (supply from other sources, demand, and the resulting price).

Considering the above, securing the investment needed to guarantee natural gas supply needed in the near term by the planned gas-fired generation will require TANESCO to improve its financial

${ }^{21}$ As of the end of 2014, TANESCO owned PAE $\$ 64.6$ million, of which $\$ 52.2$ million were in arrears. 

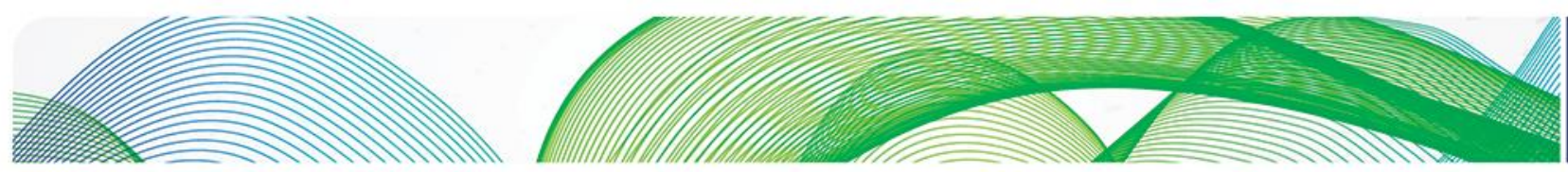

애잔

position and payment records for its existing gas supply contracts. Such incremental gas supply also requires successful contracting between TPDC and the gas field operators, as well as between the PSA partners and the power generators (TANESCO and future IPPs/PPPs. In the long term, off-shore natural gas investment is subject to international market uncertainty and not within the control of Tanzanian agents; therefore, long-term power planning needs to take this uncertainty into consideration and be prepared to further diversify generation fuel.

\section{Cost-reflective electricity tariff?}

Reflecting upon the recent history of Tanzania's electricity sector, hydrological uncertainty, an important external factor, continues to upset the precarious balance in the power sector. In the immediate term, droughts trigger the governmental decision to procure relatively expensive EPPs (which have TANESCO as their contractual off-taker) and the use of more expensive thermal generation plants by TANESCO. Given TANESCO sells electricity at regulated tariff levels, which are not freely adjusted by the utility in the short term to reflect its sudden increase in costs, it has to carry such additional costs on its balance sheet unless it receives revenue grants from the government, passes them on to ratepayers through an increased tariff, or captures more profit from existing tariff levels by reducing its spending forward.

The historical distribution of costs and revenue is illustrated in Figure 25. Between 2007 and 2010, revenue collected through tariffs was enough to cover TANESCO's cost of sales, while its other expenses (operating expenses and finance cost) were covered through other operating incomes (mainly in the form of government contribution). Starting in 2011, the revenue collected through tariffs, despite increases, no longer covers its cost of sales. Governmental contributions, also despite increases, do not make up the gap between the collected tariffs and TANESCO's full costs. Therefore, all three parties (the ratepayers, the government, and TANESCO) have borne some of the cost increases since 2011. 

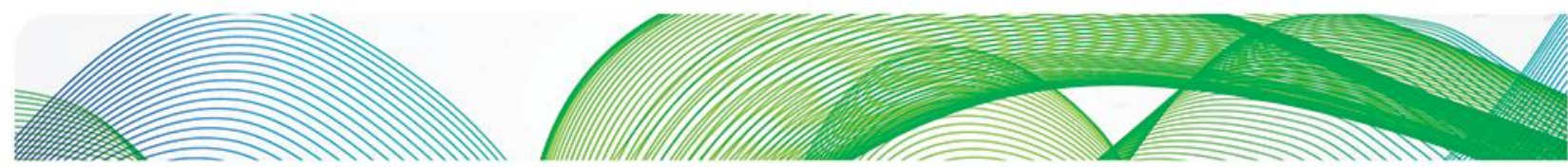

애조

Figure 25: Evolution of TANESCO revenue and revenue requirement (Data source: TANESCO)

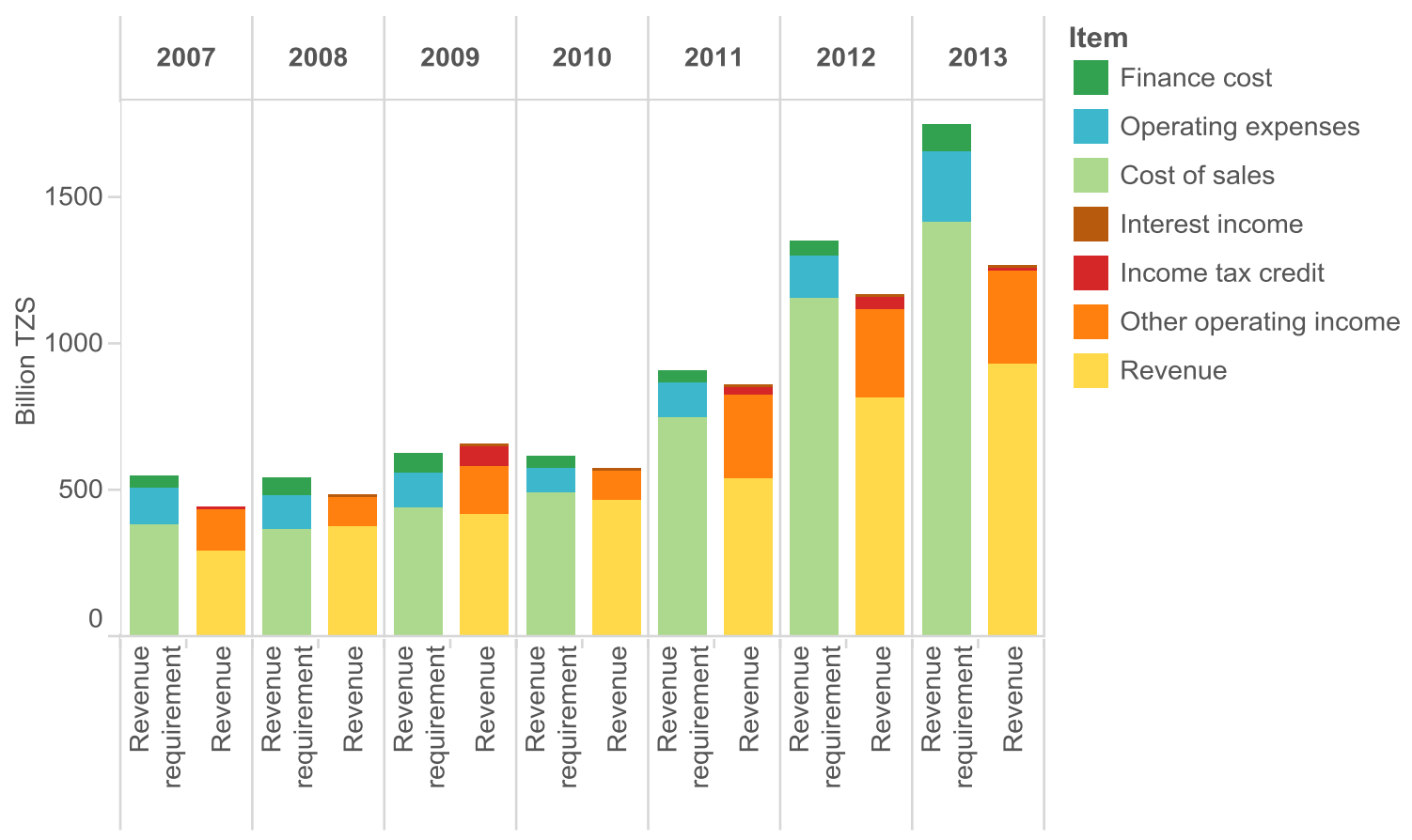

Under the current regulatory regime, it is the duty of EWURA to scrutinize all expenses incurred by TANESCO, safeguarding the interests of ratepayers, deciding which costs are to be recovered via the regulated tariff and governmental contribution, and which costs are to be borne by TANESCO through cost savings. In this section, the governing principles for electricity tariff setting and common approaches in practice are introduced, followed by a description of the tariff setting methodology used by EWURA during its most recent tariff review in 2013. The Tanzanian approach is then evaluated against the rate design principles that it upholds in local legislation.

\section{Principles of electricity tariff design}

The setting of electricity tariffs by the regulator is necessary for the network segments in countries with liberalized power sectors and for all segments in countries with vertically integrated utilities. Tariff schedules need to answer to several governing principles whenever possible. Laws, directives, and regulations of countries commonly cite the following fundamental principles (Table 6). 

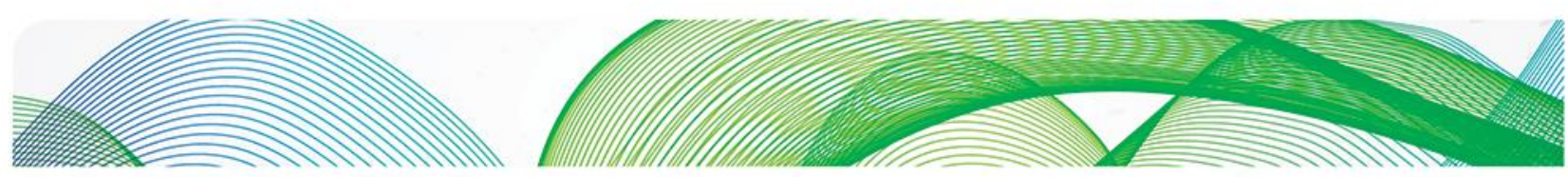

Table 6: Ratemaking principles for the power sector (Summarized from Reneses, Rodríguez, \& Pérez-Arriaga, 2013)

\begin{tabular}{ll}
\hline Principle & Objective \\
\hline $\begin{array}{l}\text { Economic } \\
\text { sustainability }\end{array}$ & $\begin{array}{l}\text { A sustainable tariff must enable a regulated company to finance its } \\
\text { businesses and new investment required for future operations. }\end{array}$ \\
\hline $\begin{array}{l}\text { Economic } \\
\text { efficiency }\end{array}$ & $\begin{array}{l}\text { An efficient tariff is a price signal that incentivizes consumers to use the } \\
\text { amount of resources that are efficient for the system as a whole. }\end{array}$ \\
\hline Equity & $\begin{array}{l}\text { An equitable tariff does not discriminate against one (group of) customer(s) } \\
\text { unduly in service provision and cost allocation. }\end{array}$ \\
\hline Transparency & $\begin{array}{l}\text { A transparent tariff has procedures and results that are published in clear } \\
\text { and understandable terms. }\end{array}$ \\
\hline Additivity & $\begin{array}{l}\text { The total sum collected from end-users by an additive tariff for a particular } \\
\text { segment should be equal to the total allowed revenues to be collected for } \\
\text { that segment. }\end{array}$ \\
\hline Simplicity & A simple tariff is easy to understand and accept. \\
\hline Stability & A stable tariff has calculation methodology that is consistent over time. \\
\hline Consistency & A consistent tariff is coherent with the industry structure and regulatory \\
framework in place in the country at any given time.
\end{tabular}

Among these ratemaking principles, equity, also referred to as 'the fairness principle', is one that has the most ambiguous definition and is interpreted differently in different countries. In some instances, it is operationalized as subsidizing electricity for low-income consumers in order to promote universal access. It can also be understood to mean that power consumption should be charged according to the burdens they impose on the system (beneficiaries pay). It is impossible to fully meet all the above principles simultaneously. Though this is sometimes due to the lack of know-how, it is more often due to inherent conflicts among the principles listed. Tariff setting methodology, which promotes the principle of economic efficiency, may clash with the principles of sufficiency, equity, or simplicity. This is demonstrated in the survey of common tariff setting methodology presented below. Therefore, it should be kept in mind that the choice of any tariff setting methodology requires the decision makers to make an informed compromise, reaching a balance among all the principles discussed.

Any methodology for determining electricity tariffs can be divided into two steps, to which the different principles apply to differing extents:

1) Calculation of allowed revenues to be recovered;

2) Definition of a tariff structure and allocation of allowed costs to the tariff structure.

For example, the determination of the allowable volume of regulated revenues mainly needs to be weighed between economic sufficiency (ensuring the company's medium and long-term viability) and economic efficiency (ensuring that resources have been allocated efficiently in the company's operations). On the other hand, the design of the tariff structure and the allocation of allowed revenues using this structure need to balance equity, efficiency (providing the end-users with price signals that motivate efficient use of electricity), and sufficiency (ensuring that receipts from tariffs concur with the volume of allowed revenues). 

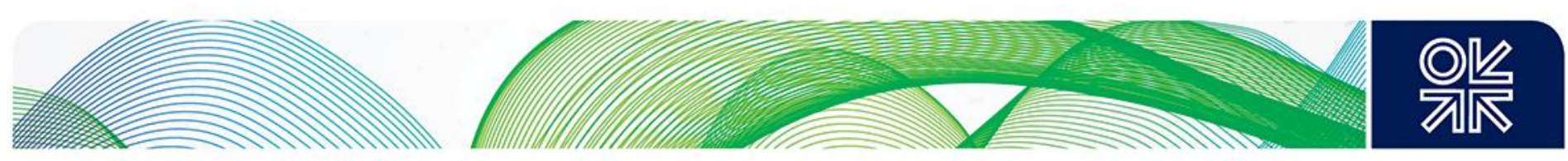

\section{Revenue determination}

There are two common ways for regulators to determine what revenue recovery should be allowed through the electricity tariff: the traditional method known as cost-of-service or rate-of-return regulation; and an extension of the first, the incentive-based regulation. The two differ mainly in the frequency that tariff reviews are conducted and how tariffs are set for intervening years between reviews.

\section{Cost-of-service regulation}

In cost-of-service regulation, the allowed regulated revenues are traditionally determined by identifying the total costs of the company based on submitted accounting information for the previous regulatory period. The following accounting formula is typically used (Reneses et al., 2013). At each tariff review, the regulator reviews all items included in the equation to arrive at the revised volume of allowed revenues.

$$
R_{\text {allowed }}=C_{\text {tot }}=C_{O M}+D+s \cdot R B+T-R_{\text {add }}
$$

$\mathrm{R}_{\text {allowed }}:$ allowed revenues

$\mathrm{C}_{\text {tot }}:$ total cost of service

$\mathrm{C}_{\mathrm{OM}}$ : allowed operating and maintenance costs

D: depreciation expenses

$\mathrm{s}$ : allowed rate of return

$\mathrm{RB}$ : rate base, gross assets less depreciation

$\mathrm{T}$ : taxes

$\mathrm{R}_{\text {add }}$ : additional revenue

The operating and maintenance costs include the cost of fuel, material and replacement parts, energy purchases, supervision, personnel, and overhead. The allowed operating and maintenance costs might not be the totality of incurred costs, since not all of them are necessarily considered prudently incurred. In practice, the determination of allowed costs may involve the use of detailed analyses of each cost item and engineering or econometric models that allow benchmarking of utility companies against each other. The allowed rate of return is commonly calculated as the weighted average cost of capital (WACC). The rate base, a measure of the value of the company's investment, is its net fixed assets (fixed assets less the cumulative depreciation), plus current assets (fuel and other inventories, research and development expenses, and current asset requirements). From year to year, it is increased by capital investment and decreased by depreciation. Due to information asymmetry, the actual rate of return resulting from the allowed revenues might be above or below the true cost of capital, leading to overinvestment (if the rate of return is higher than true WACC) or underinvestment (if the rate of return is lower than true WACC).

The valuation of the rate base is critical, especially when it is established for the first time for existing assets. There are several popular valuation methods: book value, reproduction value, replacement cost, and market value. Not all valuation methods are always available. For instance, in the case that no reliable accounting data is available (book value is not reliable) and the regulated company is not publicly traded (hence no market value is available), only the reproduction value, an estimate of the 

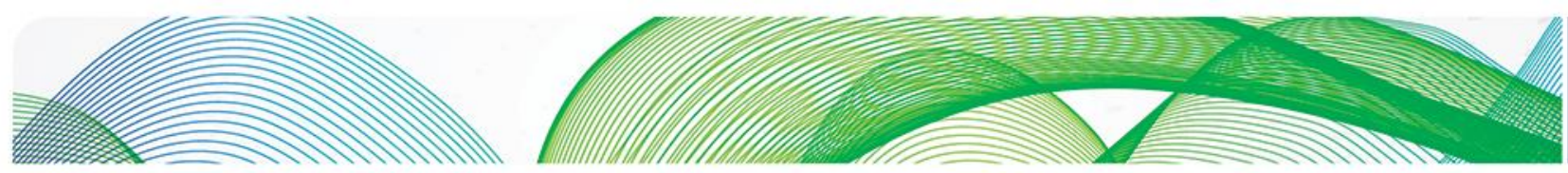

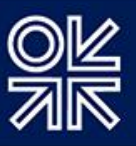

current cost of a replica of the assets, and the replacement cost, the cost of replacing current assets with new assets, can be used.

Two issues are the hardest for the utility and the regulator to agree on while reviewing the cost-ofservice: the allowed rate of return to the rate base, and the investments to be included in the rate base. For the rate of return, a regulator has discretion in the rate of return awarded to the equity portion of the capital invested, since the cost of debt is known. For the rate base, a regulator needs to decide whether to include works in progress in the rate base, ignoring delay between investment and commissioning to reward capital during construction, and what valuation methods to use to determine the rate base.

In terms of the equation below, including works in progress in the rate base is equivalent to setting the delay $d$ to zero, directly adding all investment to the rate base, regardless of construction time. Not including them is the equivalent of setting $d$ to the construction time required, therefore investments are only added to the rate base once construction has ended.

$$
R B_{t}=R B_{0}-\sum_{1}^{t} D_{t}+\sum_{d}^{t-d} I_{t}
$$

$\mathrm{RB}_{\mathrm{t}}$ : rate base for the year $\mathrm{t}$

$\mathrm{RB}_{0}$ : initial rate base

D: depreciation

I: investment

d: delay for investment to be added to the rate base

\section{Incentive-based regulation}

The determination of costs can be based directly on actual expenditure for the past accounting period (ex post), or be based on forecast of expenditure informed by historical information (ex ante). It is possible to affect the incentives of the regulated company through the choice of sources of cost information.

$$
R_{\text {allowed }}=(1-b) C_{\text {ex-ante }}+b C_{\text {ex-post }}
$$

$\mathrm{R}_{\text {allowed }}$ : allowed revenues

b: coefficient, $0<\mathrm{b}<1$

$\mathrm{C}_{\text {ex-ante }}$ : estimated costs or costs allowed under incentive regulation

$\mathrm{C}_{\text {ex-post }}$ : incurred costs

When the value of the coefficient $b$ approaches 1 , the company is allowed to recover all the costs incurred and has low incentive to operate efficiently, since savings will not result in additional revenues. This is the case of cost-of-service regulation with annual or frequent reviews. When the value of the coefficient $b$ approaches 0 , the company is incentivized to cut costs in order to maximize profits, by harvesting the difference between the ex ante allowed revenues and actual costs, the most extreme case being a tariff freeze. By increasing the period between price reviews, cost-of-service 

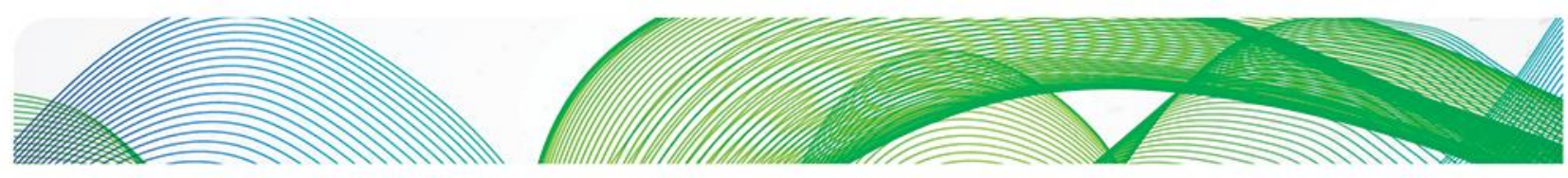

䢰

regulation achieves a lower $b$ coefficient, because the ex post assessment of allowed cost is maintained so that it becomes an ex ante assessment for the years further away from the tariff review.

Compared to traditional cost-of-service regulation, incentive-based regulation allows a company to receive more revenue during a regulatory period, but passes on the savings achieved by the companies to customers in the following regulatory period through the tariff review. If the tariff is frozen (an extreme form of incentive-based regulation) and adjustment toward ex post does not occur, then the total revenues received by the company may be excessively high, so customers are overcharged, or excessively low, so the sustainability of the company is threatened. Therefore, an intermediate value for the coefficient $b$ is preferable. In practice, the period between tariff reviews is typically four to five years, and the process for the tariff review is similar to the process described for the cost-of-service regulation.

Two basic schemes for incentive-based regulation exist: price cap and revenue cap. When tariff reviews are far apart, it is important to take into consideration the effect of inflation and events beyond the control of the utility, such as fuel price increases, and incorporate them into the price or revenue cap. A productivity factor is also used to account for increases in productivity (hence an annual decrease in price/revenue). In the first case, the price that the company can charge for each service throughout the regulatory is set by the following formula:

$$
\bar{P}_{m, t}=\bar{P}_{m, t-1} \times\left(1+R P I_{t}-X\right) \pm Z
$$

$\overline{\mathrm{P}}_{\mathrm{m}, \mathrm{t}}:$ maximum price for service $\mathrm{m}$ in year $\mathrm{t}$

$\mathrm{RPI}_{\mathrm{t}}$ : the annual price variation per unit (retail price index or inflation rate) in year $\mathrm{t}$

$\mathrm{X}$ : productivity factor per unit

$\mathrm{Z}$ : adjustment owing to unforseen events

The common formula that specifies the revenue cap during the regulatory period looks similar:

$$
R_{\text {allowed }, t}=R_{\text {allowed }, t-1} \times\left(1+R P I_{t}-X\right) \pm Z
$$

$\mathrm{R}_{\text {allowed,t-1 }}:$ allowed revenues in the previous year

$\mathrm{RPI}_{\mathrm{t}}$ : annual price variation (retail price index or inflation rate) in year $\mathrm{t}$

$\mathrm{X}$ : the productivity factor per unit

$\mathrm{Z}$ : any adjustment owing to unforseen events beyond the control of the utility

In order to avoid deterioration in the quality of service provided due to aggressive cost cutting, it is necessary to set service quality standards for the regulated company, which include measures such as the number and severity of power supply outages, the number of end-users connected to the power grid (in the case that electrification rate is low), and the level of consumer satisfaction.

\section{Tariff structure and allocation}

Once the volume of allowed revenues is determined, it is still necessary to perform the second step of the rate-setting methodology: to decide on the structure that the tariff should adopt (once decided, this is seldom changed upon tariff review) and the costs to be allocated to each element in the 

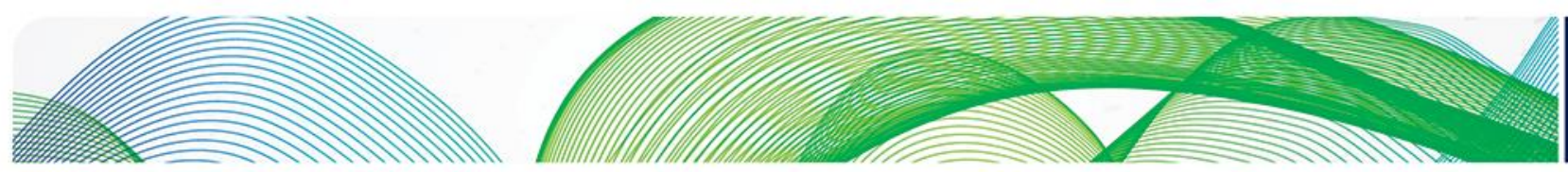

O는

structure. The regulator may choose to allow the company flexibility to design its end consumer tariffs based on its allowed revenues or to design the end-user tariff itself to prevent cost shifting among consumer classes.

The structure of the tariff is supposed to be a simplified representation of the cost structure for providing electricity. The exact costs of providing for each individual consumer at each moment in time are all different, but in practice tariff structure typically differentiates end-users in limited ways due to metering/billing limitations, and the necessity to remain comprehensible to the consumers. Possible categorization of end-users can be done by the voltage level of the connection, by geographic area, by season, by blocks of hours, or by sector. For each category of end-users, the tariff can contain an element based on the maximum capacity contracted/installed (per kW), an element based on the energy consumed (per kWh), and a fixed charge (per connection). This is because capacity requirement, energy consumption, and number of customers are the three key cost drivers.

The two dominant approaches in allocating costs to an accepted tariff structure are the accounting approach and the marginal cost approach.

The accounting approach requires the breakdown of total allowed revenues into different functional segments, followed by further breakdown into several cost components: costs associated with demand (installed capacity), costs associated with the amount of energy produced, and costs associated with the number of users - matching the three components of the aforementioned tariff structure. Finally, the costs itemized by function and component are allocated among end-users of all categories, and the costs allocated to each category is averaged over all users of the same category (Parmesano, Rankin, Nieto, \& Irastorza, 2004). Given that the cost allocated to different categories is averaged over the demand, energy consumption, and number of end-users belonging to the same category, the accounting approach is also known as the average cost approach. 

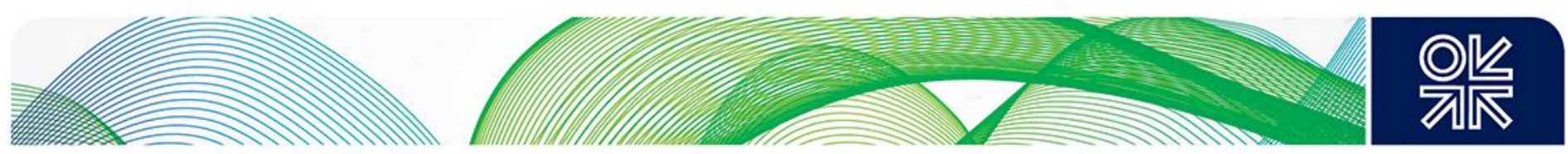

Figure 26: The accounting approach for cost allocation

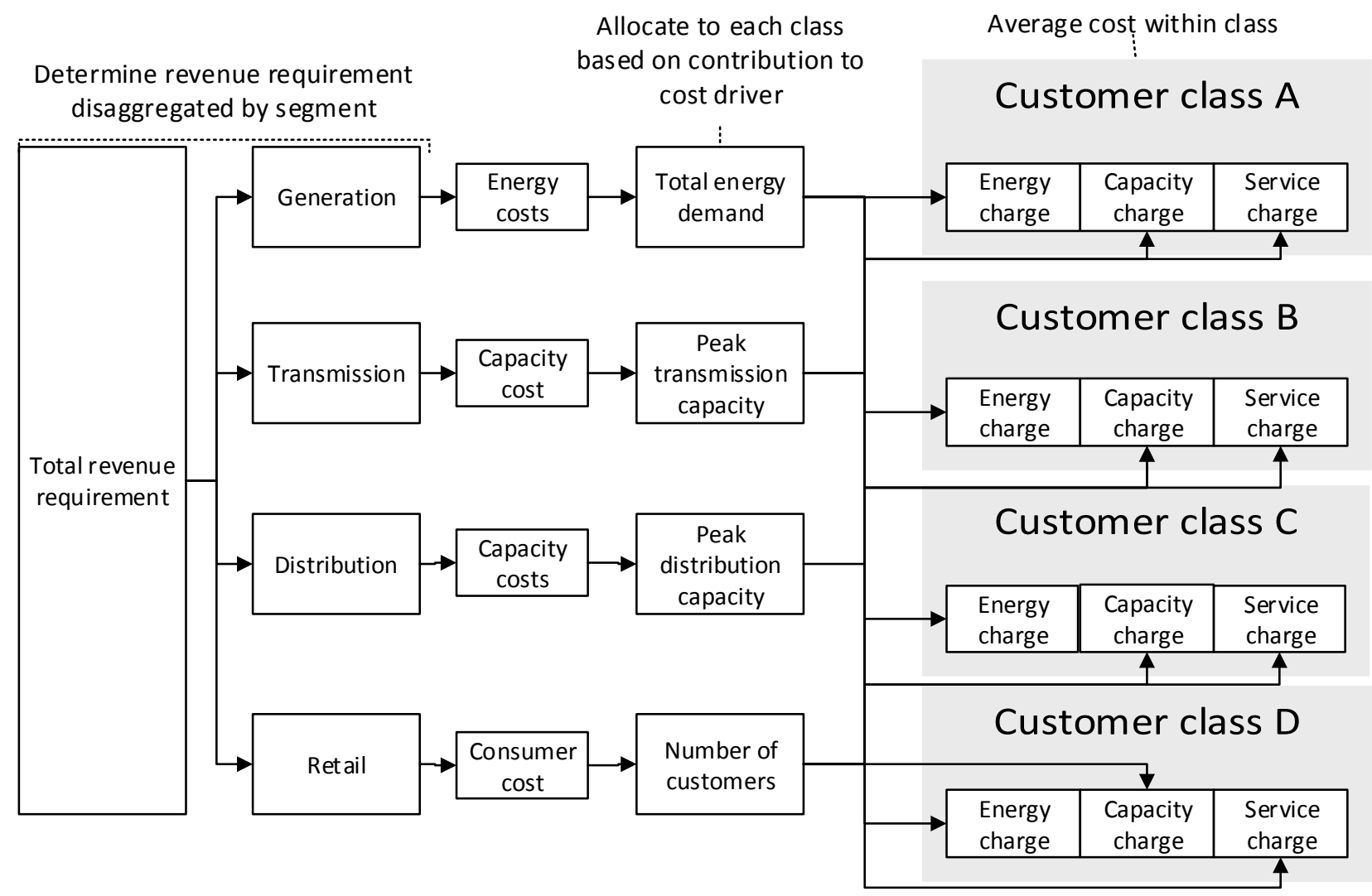

The marginal cost-based approach, unlike the accounting approach, does not directly allocate the allowed revenues to be recovered over the tariff structure. Instead, it allocates the Long-Run Marginal Cost (LRMC) - the economic value of future resources required to meet incremental changes in consumption of electricity over the next 5-10 years - for each category of customers. For example, if the use of more expensive generation is required with an incremental increase in electricity demand, then the LRMC is higher than the current cost. Similarly, if the use of a less expensive generation technology is needed with an incremental increase in electricity (typically due to economies of scale), then the LRMC is a value that is lower than the current cost. Detailed procedures for the calculation of capacity, energy, and consumer components of LRMC for the generation, transmission, and distribution segments can be found in Munasinghe's discussion of modern electricity pricing ( Munasinghe, 1981). After that, the revenue that can be collected with tariffs set equivalent to LRMC values is estimated and compared to the total revenue that is required to cover all current expenses. Typically, the two revenues are not equivalent and revenue reconciliation is required. If the revenue collected based on LRMC is more than the total current expenses of the utility, the surplus could be taxed away or used on subsidizing non-energy related charges such as connection fees. Conversely, when the revenue collected based on LRMC is lower the total current expenses of the utility, then the deficit could be made up by higher connection fees, service fees, or even government subsidies. 

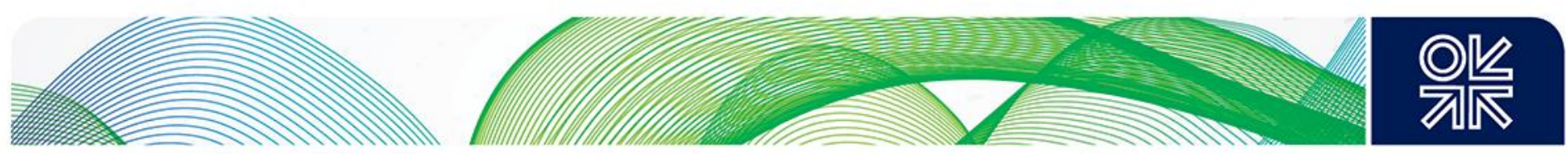

Figure 27: The marginal cost approach for cost allocation

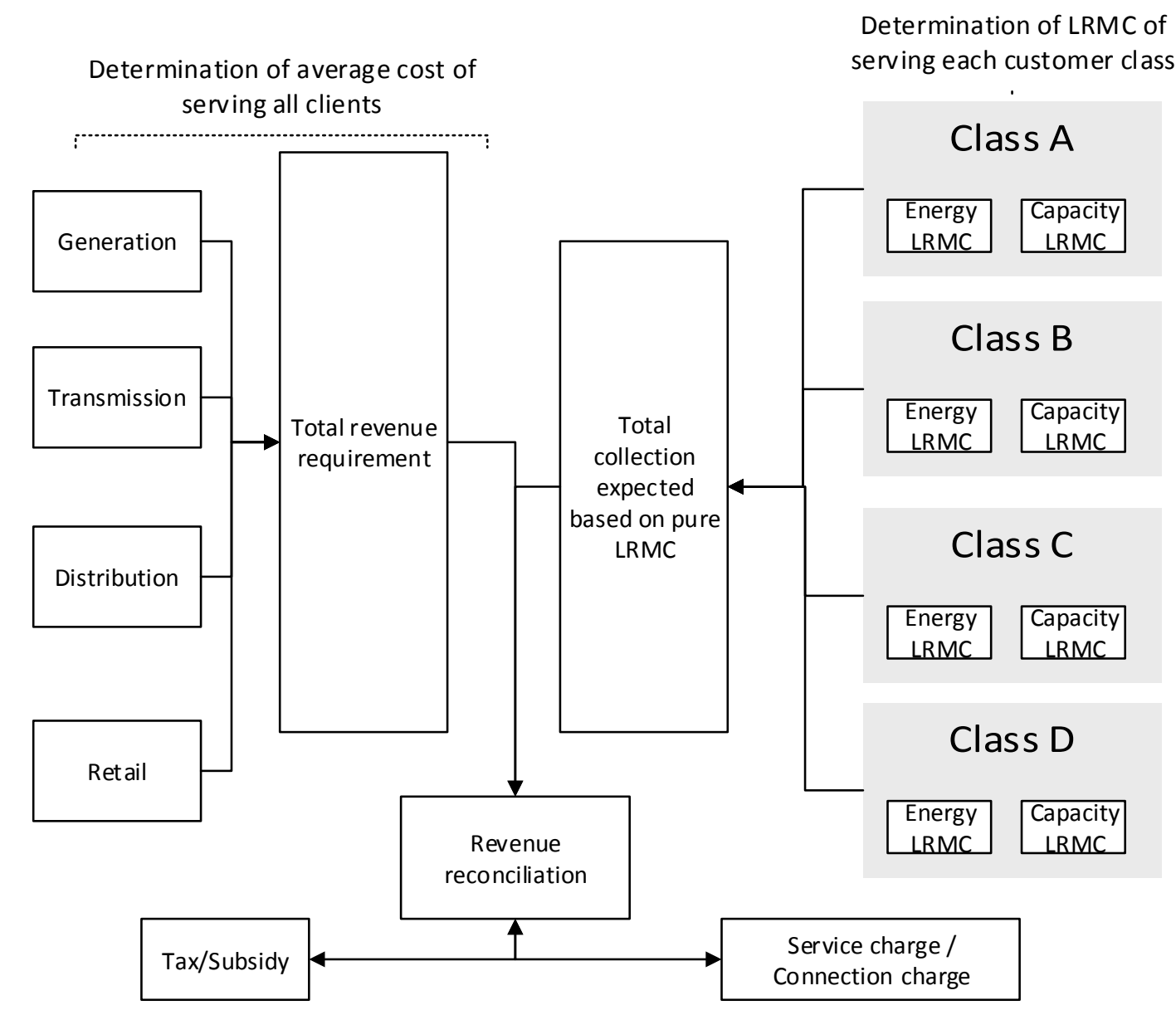

These two methods each have their advantages and disadvantages. The direct allocation of allowable costs in the accounting approach, which averages costs components over different consumer categories, provides end-users with cost signals largely based on historical costs. This signal implies that the future costs of providing electricity will be as cheap or as expensive as in the past, potentially leading to over-consumption or under-consumption of electricity, infringing the principle of economic efficiency. However, this approach is relatively simple to understand and to use, and the regulated company can be sure that all allowable regulated revenues are recovered. On the other hand, if prices were set equal to the strict LRMC, then customers would be informed of the marginal cost of their electricity consumption and thus make their decisions correspondingly: lowering their consumption if the LRMC is high and increasing it if the LRMC is low. However, the tariff revenue collected based on LRMC is likely to be different from the actual costs the utility incurred in providing electricity: a surplus is collected when the LRMC is higher than the current average cost, such as in the case that incremental consumption will require the use of more expensive generation unit, and a deficit is experienced when the LRMC is lower than the current average cost, such as in the case that incremental consumption will allow economies of scale given an existing generator is not fully utilized 

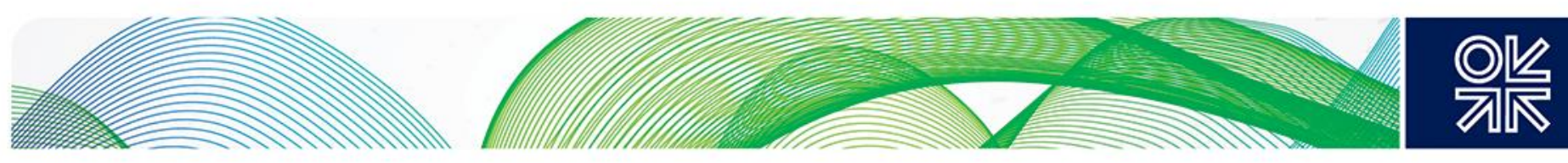

(Figure 28). The mismatch of revenue collected and cost incurred infringes the principle of economic sufficiency, which then requires revenue conciliation. If not executed carefully, this could compromise the efficiency of the LRMC tariff. In other words, the marginal cost approach provides ratepayers with cost information about the future, whereas the average cost approach is based on historical data and thus provides ratepayers with cost information about the past. Applying the marginal cost approach will lead to a tariff allocation process that is more complex and that will sometimes require revenue reconciliation, so the revenues collected based on future-oriented costs match the historical ones incurred by the utility. However, it is theoretically more conducive to efficient use of electricity, since the customers are made aware of the implications of their consumption choices.
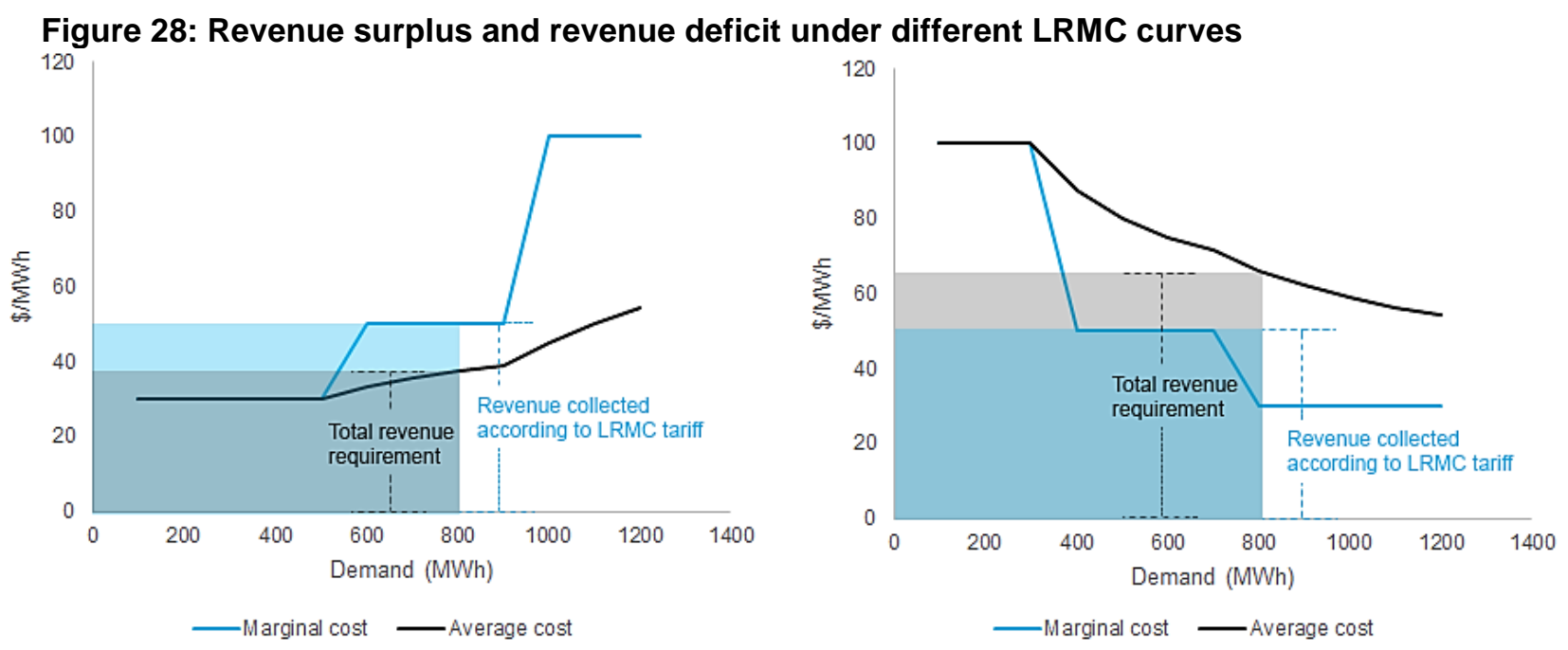

When it comes to the principle of equity, the performances of both cost allocation methods vary depending on which interpretation is adopted. First, neither directly address access to electricity for low-income consumers. This social concern is often dealt with through the implementation of a lifeline rate, providing lower subsidized rates for a first block of consumption, deemed enough to cover basic needs, possibly reinforced by subsidized connection fees. As for the 'beneficiaries pay' interpretation, the strict marginal cost approach embodies this interpretation in principle, but it is commonly modified to achieve economic sufficiency (in the case that the non-modified tariffs would lead to a deficit in the utility's budget) or to avoid consumer resistance (in the case the non-modified tariffs would lead to a surplus in the utility's budget) (Munasinghe, 1981). The array of adjustment methods available has implications for different rate making principles.

\section{Current electricity tariff setting in Tanzania}

At the time of writing, remuneration for the electric power industry in Tanzania is recovered via a multiyear integral tariff, proposed by TANESCO and approved by EWURA, to be reviewed at least once in every three years. This is equivalent to the price cap variety of incentive-based regulation with a standard regulatory lag. The integral tariff does not distinguish between the origin of costs that need to be recovered into functional segments such as generation, transmission, and distribution. This is a feature which reflects the fact that Tanzania's power industry structure is not yet unbundled. 

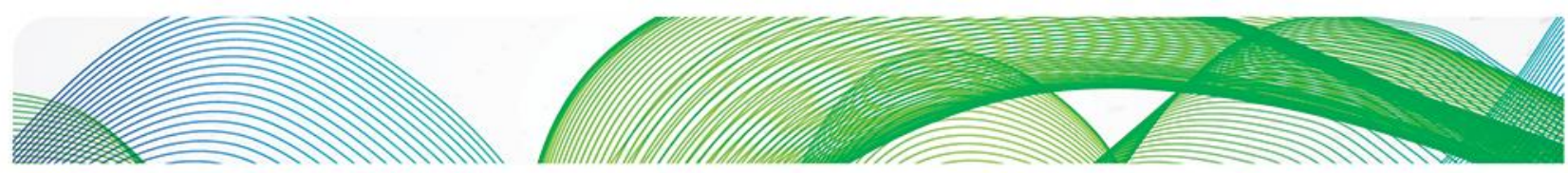

O는

Since the establishment of EWURA in 2006, the regulator has already undertaken five rounds of tariff reviews (Table 7 ). This section describes the rate-setting principles upheld by Tanzanian legislation and the integral tariff determination process in use during the latest tariff review. A tariff review is planned for the year of writing (2016), but it had not taken place by the time the authors completed research for this paper, therefore it is not included as part of this study.

Table 7: History of EWURA tariff reviews (Based on: EWURA, 2012a, 2013; TANESCO, 2013)

\begin{tabular}{|c|c|c|c|c|c|}
\hline \multirow[t]{2}{*}{$\begin{array}{l}\text { Proposal } \\
\text { submitted } \\
\text { on }\end{array}$} & \multirow[t]{2}{*}{$\begin{array}{l}\text { Proposed } \\
\text { tariff }\end{array}$} & $\begin{array}{l}\text { Tariff } \\
\text { approved } \\
\text { on }\end{array}$ & $\begin{array}{l}\text { Approved } \\
\text { tariff }\end{array}$ & EWURA comments & \multirow{2}{*}{$\begin{array}{l}\text { Valid } \\
\text { starting } \\
\text { from }\end{array}$} \\
\hline & & & $\begin{array}{l}6 \\
\text { increase }\end{array}$ & Cater for inflation applicable & \\
\hline Aug 2007 & $40 \%$ increase & Dec 2007 & $\begin{array}{l}21.7 \% \\
\text { increase }\end{array}$ & $\begin{array}{l}\text { Only to cover its operation } \\
\text { and maintenance costs, } \\
\text { except for depreciation and } \\
\text { provision for doubtable debts } \\
\text { Direct TANESCO to order } \\
\text { CoSS }\end{array}$ & $\begin{array}{l}\text { Jan } \\
2008\end{array}$ \\
\hline May 2010 & 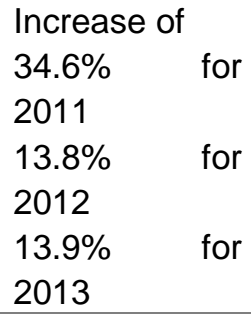 & Dec 2010 & $\begin{array}{l}18.5 \% \\
\text { increase }\end{array}$ & $\begin{array}{l}\text { CoSS found unsatisfactory: } \\
\text { assumptions, concepts, data } \\
\text { are not reflective of true costs } \\
\text { CoSS ordered by EWURA } \\
\text { from AF-Mercados }\end{array}$ & $\begin{array}{l}\text { Jan } \\
2011\end{array}$ \\
\hline \multirow[t]{2}{*}{ Nov 2011} & \multirow[t]{2}{*}{$\begin{array}{l}155 \% \text { increase } \\
\text { due to EPP }\end{array}$} & Jan 2012 & $\begin{array}{l}40.29 \% \\
\text { increase }\end{array}$ & $\begin{array}{l}\text { Determined based on } \\
\text { forward looking AF- } \\
\text { Mercados CoSS rate-setting } \\
\text { methodology }\end{array}$ & $\begin{array}{l}\text { Jan } \\
2012\end{array}$ \\
\hline & & Jan 2013 & $\begin{array}{l}2012 \text { tariff } \\
\text { maintained }\end{array}$ & $\begin{array}{l}\text { TANESCO has withdrawn } \\
\text { application for } 155 \% \\
\text { increase in Jan } 2013\end{array}$ & $\begin{array}{l}\text { Jan } \\
2013\end{array}$ \\
\hline Sept 2013 & $\begin{array}{l}\text { Increase of } \\
67.87 \% \text { for } \text { Oct } \\
2013 \\
12.74 \% \text { for } \\
2014 \\
9.17 \% \text { for } \\
2015\end{array}$ & Dec 2013 & $\begin{array}{l}39.19 \% \\
\text { increase }\end{array}$ & $\begin{array}{l}\text { Determined based on } \\
\text { forward looking AF- } \\
\text { Mercados CoSS rate-setting } \\
\text { methodology }\end{array}$ & $\begin{array}{l}\text { Jan } \\
2014\end{array}$ \\
\hline
\end{tabular}

Section 23.2 of the 2008 Electricity Act states that the EWURA shall be guided by the following principles:

a) Tariffs should reflect the cost of efficient business operation; 

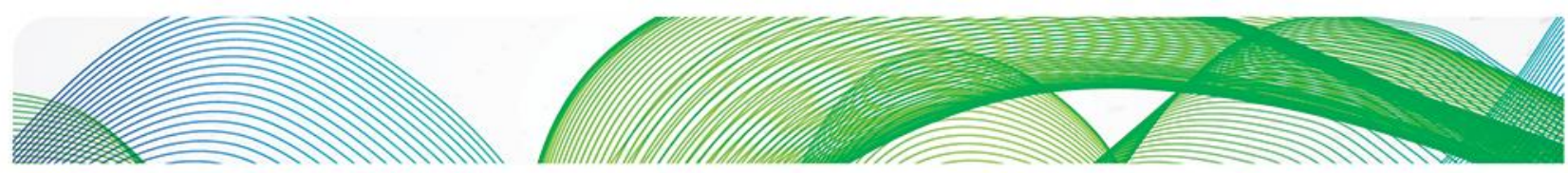

애잠

b) Tariffs should allow licensees to recover a fair return on their investments, provided that such investments have been approved by the Authority;

c) Costs covered by subsidies or grants provided by the Government or donor agencies shall not be reflected in the costs of business operation;

d) Tariff adjustments shall, to the extent possible, ensure price stability;

e) Access charges for use of transmission or distribution system shall be based upon comparable charges for comparable use;

f) No customer class should pay more to a licensee than is justified by the costs it imposes upon such a licensee;

g) Tariffs should enhance efficiency in electricity consumption and should encourage adequate supply to satisfy demand.

These principles reflect the general rate making principles of economic efficiency (items a and g), economic sufficiency (item b), stability (item d) and equity (items c, e, and f). Subsection 23.2.c reflects the fact that a significant part of the Tanzanian power infrastructure is financed through public funds or development grants, which should be distinguished from other assets in the utility's rate base. The questions that need to be answered while scrutinizing the integral tariff in place are therefore focused on the legislated principles mentioned above (Table 8).

Table 8: Evaluation framework for the tariff setting mechanism in Tanzania

\begin{tabular}{lll}
\hline Principle & Revenue determination & Tariff allocation \\
economic & $\begin{array}{l}\text { Do the allowed revenues, to be } \\
\text { recovered from ratepayers, represent } \\
\text { efficient use of resources by } \\
\text { TANESCO? }\end{array}$ & $\begin{array}{l}\text { Does the tariff charged incentivize } \\
\text { consumers to use electricity } \\
\text { efficiently? }\end{array}$ \\
\hline $\begin{array}{l}\text { Economic } \\
\text { sufficiency }\end{array}$ & $\begin{array}{l}\text { Are the allowed revenues to be } \\
\text { recovered sufficient to cover the } \\
\text { operating expenditures of the licensees, } \\
\text { including a reasonable rate of return for } \\
\text { the capital invested? }\end{array}$ & $\begin{array}{l}\text { Does the totality of tariff charged } \\
\text { correspond to the allowed revenues } \\
\text { (additivity)? }\end{array}$ \\
\hline Equity & $\begin{array}{ll}\text { How are grants from the government } \\
\text { and development partners treated in the } \\
\text { computation of the revenue }\end{array}$ & $\begin{array}{l}\text { Are there cases when customer } \\
\text { classes are charged more than the } \\
\text { requirement? }\end{array}$ \\
& & $\begin{array}{l}\text { costs they impose upon TANESCO } \\
\text { (cross-subsidization)? How are such } \\
\text { cases justified? }\end{array}$
\end{tabular}

Stability

Is the approved tariff stable over time?

The Tariff Application Guidelines 2009 describe the procedures to be followed by an applicant and by EWURA when processing a tariff application. They are applicable to all regulated suppliers seeking a new tariff or to change an existing one. The guidelines encourage economic efficiency and sufficiency in principle. They set out in writing that tariffs approved by EWURA shall reflect 'prudentlyincurred costs of providing the regulated service' which are independently verifiable, and that, in the case that a tariff change that will not attain full cost recovery is proposed by the applicant, a plan for attaining full cost recovery shall be supplied (EWURA, 2009, p.1). Upon receiving the application, EWURA held public hearings and consultations with the Government Consultative Council and EWURA Consumers Consultative Council. Based on the guiding clauses cited previously, the 

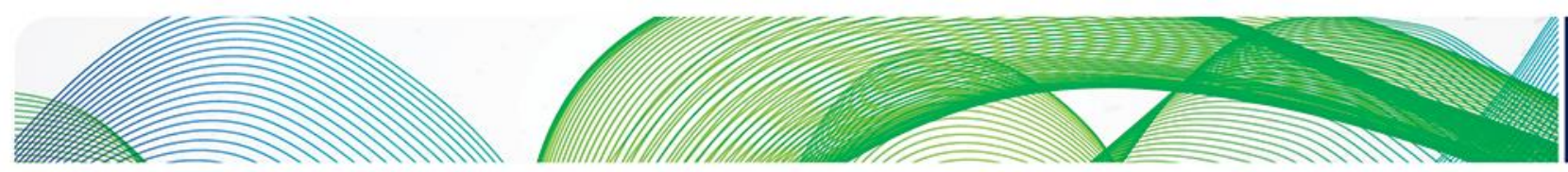

인

discussion from public consultations, and the Cost of Service Study (CoSS) performed by AFMercados, the multi-year tariffs were determined. (EWURA, 2013). EWURA concluded that the proposed tariff increase by TANESCO was reasonable, except for some key elements which were adjusted to arrive at the approved tariff. Nevertheless, the final tariff approved by EWURA for the 2013-15 regulatory period is significantly lower than that proposed by TANESCO.

\section{Revenue determination}

In this section, the revenue requirement as per TANESCO's 2013 tariff application is presented. It is then compared to the AF-Mercados 2012 CoSS, the only benchmark study available, as an approximate evaluation of its efficiency. Finally, the revenue approved by EWURA is compared with the original TANESCO proposal.

\section{TANESCO proposal}

According to the 2009 guidelines, the formula for computing revenue requirement, unless another has been approved by EWURA, is the following (EWURA, 2009, p. 5):

$$
R_{\text {required }}=C_{O M}+D+T+W A C C \cdot R B
$$

$\mathrm{R}_{\text {required }}:$ revenue requirement

$\mathrm{C}_{\mathrm{OM}}$ : allowed operating and maintenance costs, including general and administrative expenses

D: depreciation expenses

WACC: weighted average cost of capital

RB: rate base, gross assets less depreciation

$\mathrm{T}$ : taxes

However, in the 2013 tariff application, TANESCO uses a different formula to compute its revenue requirement (TANESCO, 2013, p. 5).

$$
R_{\text {required }}=C_{O M}+D+L+I-R_{\text {other }}
$$

$\mathrm{R}_{\text {required }}:$ revenue requirement

$\mathrm{C}_{\mathrm{OM}}$ : allowed operating and maintenance costs, including general and administrative expenses

D: depreciation expenses

L: loan repayment

I: investment plan

$\mathrm{R}_{\text {other }}$ : revenue from other sources 

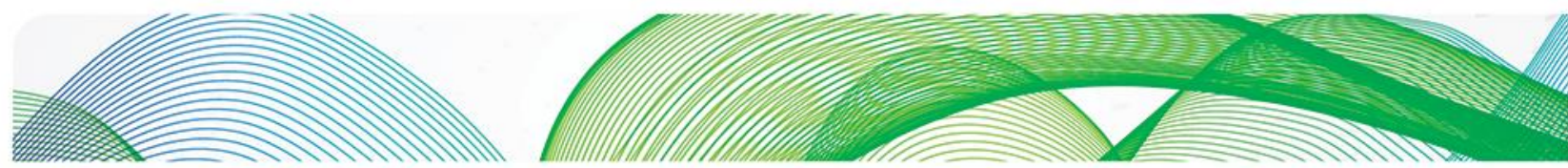

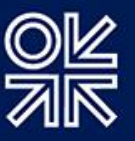

The evolution of revenue requirement computed by TANESCO in its 2013 tariff application is presented in Figure 29. The per unit revenue requirement, averaged over the expected sales of electricity, is also shown. A detailed breakdown of revenue requirement forecasted for the year 2013 is shown in Figure 30.

In TANESCO's application, operating expenses represent the most important component of the five categories, expected to rise in absolute terms but stabilize on a per unit basis since its historical increase in 2012. Financial costs - loan interest payments and fees due to long outstanding creditors - are expected to increase and other operating income (including government subsidy) decrease. Finally, depreciation and TANESCO's Capital Investment Plan (CIP) remain at similar levels throughout the entire period forecasted.

Figure 29: The evolution of historical (2011-12) and forecasted (2013-15) components making up revenue requirement (Data source: TANESCO, 2013)

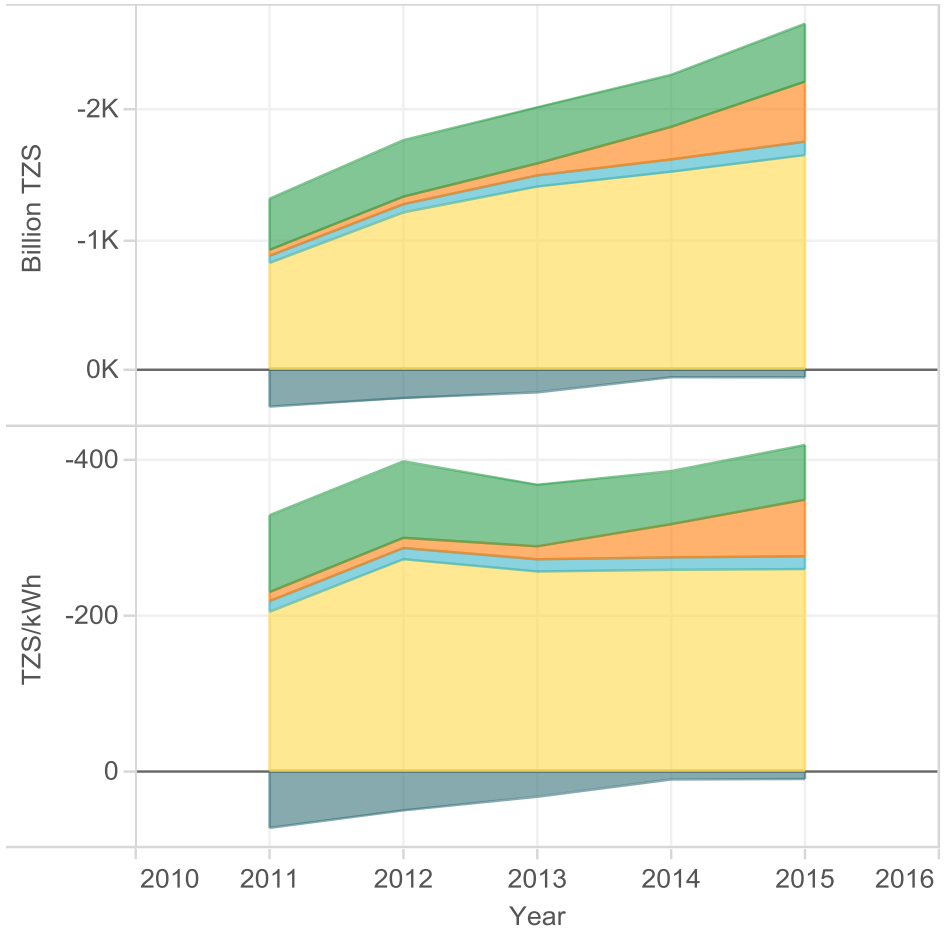

Item (group)

TANESCO CIP

Financial costs

Operating expenses

Depreciation

Revenue from other sources 

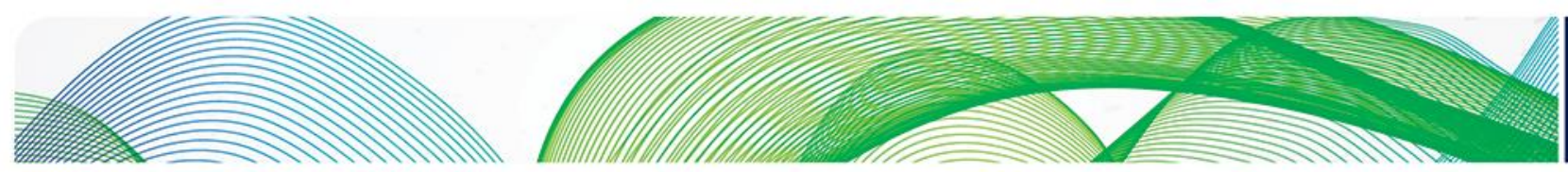

애존

Figure 30: Breakdown of TANESCO forecasted 2013 revenue requirement (Data source: TANESCO, 2013)

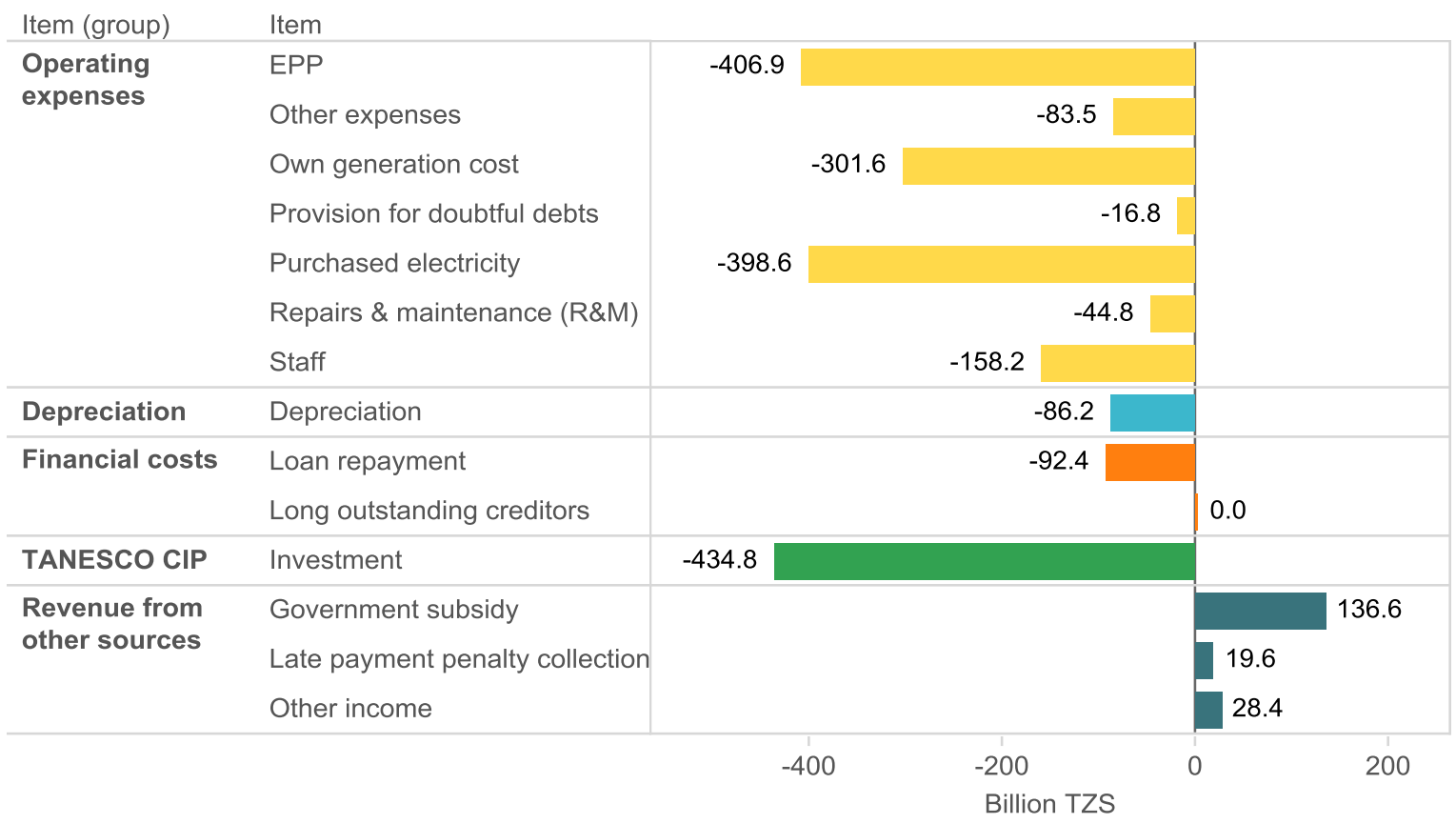

TANESCO has also requested that a tariff indexation mechanism be used to adjust changes in costs that are outside of TANESCO control, so that the tariff revenue keeps pace with rising costs during periods between formal reviews. Local inflation and foreign exchange rate fluctuation adjustments based on reports as published by the Bank of Tanzania are proposed, along with the indexation of fuel costs. It is hoped that the adjustments would be published by EWURA on a quarterly basis. The formula that TANESCO proposes to compute fuel adjustment in its tariff application possibly contains layout mistakes (TANESCO, 2013, p. 8).

$$
F A C_{t-1}=\frac{\sum_{i} p_{i, t-1} Q_{i, t-1}}{A S_{i, t-1}-B F C_{i, t-1}}
$$



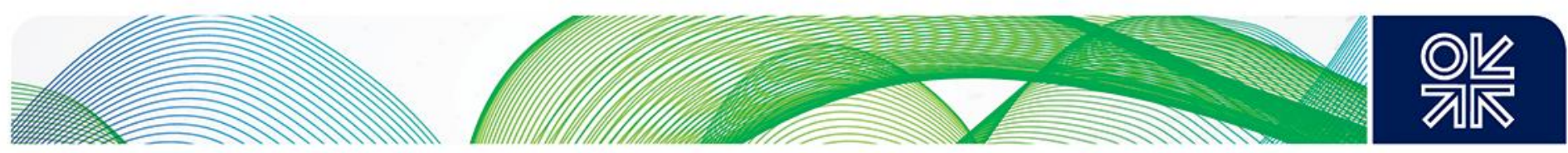

FAC $_{\mathrm{t}-1}$ : Fuel adjustment in month $\mathrm{t}-1$

$\mathrm{p}_{\mathrm{i}, \mathrm{t}-1}$ : Actual price of fuel $\mathrm{i}$ and associated operating costs in month $\mathrm{t}-1$

$\mathrm{Q}_{\mathrm{i}, \mathrm{t}-1}:$ Actual quantity of fuel $\mathrm{i}$ consumed in month $\mathrm{t}-1$

$\mathrm{AS}_{\mathrm{i}, \mathrm{t}-1}$ : Actual end use energy sold in month $\mathrm{t}-1$

BFC $_{i, t-1}$ : Base fuel cost per energy forecast to be sold as approved by EWURA

It is believed that the following formula was intended, after the consistency of physical units is checked:

$$
F A C_{t-1}=\frac{\sum_{i} p_{i, t-1} Q_{i, t-1}}{\sum_{i} A S_{i, t-1}}-\sum_{i} B F C_{i, t-1}
$$

FAC $_{\mathrm{t}-1}$ : Fuel adjustment in month $\mathrm{t}-1, \$ / \mathrm{kWh}$

$\mathrm{p}_{\mathrm{i}, \mathrm{t}-1}$ : Actual price of fuel $\mathrm{i}$ and associated operating costs in month $\mathrm{t}-1$, \$MMBTU

$\mathrm{Q}_{\mathrm{i}, \mathrm{t}-1}$ : Actual quantity of fuel i consumed in month t-1, MMBTU

$\mathrm{AS}_{\mathrm{i}, \mathrm{t}-1}$ : Actual end use energy sold in month $\mathrm{t}-1, \mathrm{kWh}$

BFC $_{i, t-1}$ : Base fuel cost per energy forecast to be sold as approved by EWURA, \$/kWh

The above fuel cost adjustment formula passes on all changes in fuel consumption and fuel prices relative to the planned ones to the ratepayers. In the case that fuel consumption/prices increased, the fuel adjustment charge would be the difference between the actual fuel cost incurred per unit sold and the approved fuel cost, an increase in the energy charge for all tariffs. Conversely, in the case that fuel consumption/prices decreased, the fuel adjustment would be a decrease in the energy charge for all tariffs. This formula does not explicitly state the actual generation (it is different from the actual sales due to commercial and technical losses), therefore the adjustment does not reflect whether the fuel costs are efficiently incurred. By February 2016, automatic fuel cost adjustment had not yet been implemented.

\section{Comparison with AF-Mercados CoSS}

The consultancy AF-Mercados conducted a CoSS as per request of EWURA and published it in January 2013, eight months before TANESCO's tariff application. The same consultancy designed a rate-setting methodology which has been used by EWURA as a reference since 2012. The AFMercados CoSS is the best approximate for TANESCO's efficient costs. Therefore, its findings are compared to the TANESCO proposal.

Within the CoSS, the total revenue requirement of the utility is determined based on cost estimates for each segment: generation, transmission, and distribution. 

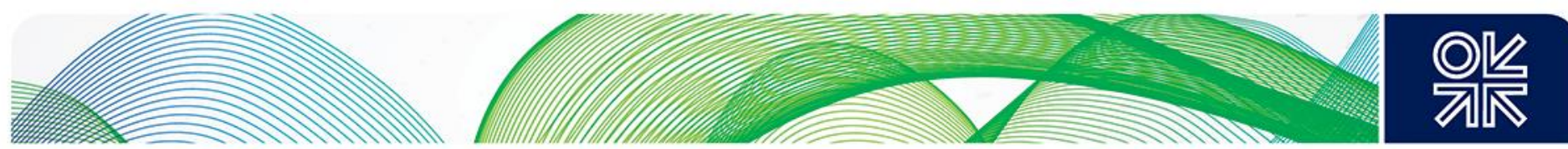

$$
R_{\text {required }}=R_{G}+R_{T}+R_{D}
$$

$\mathrm{R}_{\mathrm{G}}$ : revenue requirement for the generation segment

$\mathrm{R}_{\mathrm{T}}$ : revenue requirement for the transmission segment

$R_{D}$ : revenue requirement for the distribution segment

Since TANESCO did not present its revenue requirement per functional segment, the items that it reported as part of its revenue requirement were sorted based on assumptions in Appendix II to provide best estimates that could be compared with the CoSS values. It is also noted that two components of the TANESCO tariff application - revenue from other sources and financial costs are not addressed in the CoSS. They are discussed separately in terms of their efficiency.

To estimate costs incurred by the generation segment in 2013-15, the consultants used the demand forecast and generation expansion plan outlined in the PSMP of 2011, and they assumed fixed fuel price and typical water conditions (as opposed to low water conditions) for the three years forecasted. The total generation segment revenue requirement included plant dispatch variable costs (variable O\&M and fuel consumption) and fixed cost (fixed O\&M costs and annualized capital expenses). The annualized capital costs were not calculated but directly taken from the PSMP, bundled with fixed O\&M costs. Theoretically, they should incorporate the joint effect of reward to capital invested and depreciation. Therefore, Equation (1.11) is closer to Equation (1.6) than Equation (1.7).

$$
R_{G}=C_{O M, \text { var }}+\left(C_{O M, f i x}+A\right)
$$

$\mathrm{C}_{\mathrm{f}}$ : fuel cost

$\mathrm{C}_{\mathrm{OM}, \mathrm{var}}$ : variable $\mathrm{O} \& \mathrm{M}$ cost

$\mathrm{C}_{\mathrm{OM}, \mathrm{fix}}:$ fixed O\&M cost

A: annualized capital cost

Fuel consumption, the most important contributor to variable O\&M cost, is dependent on the demand and the mix of generation dispatched to meet it. The gross demand forecast used by the CoSS, including electricity that is generated but lost during transmission and distribution, and the gross demand inferred from TANESCO forecasted sales (based on known T\&D loss targets) are compared in Figure 31. The TANESCO estimate is visibly lower than the CoSS estimate. This is an important difference, because it indicates that the generation revenue requirements computed by AF-Mercados and TANESCO cannot be compared in their absolute terms, because they are calculated based on different electricity provision requirements. Instead, the unit cost should be used for comparison. 

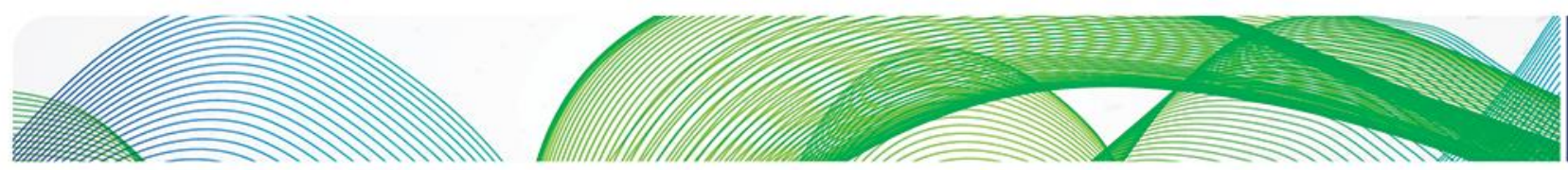

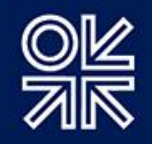

Figure 31: Comparison of gross power demand (Data source: AF-Mercados, 2013; TANESCO, 2013)

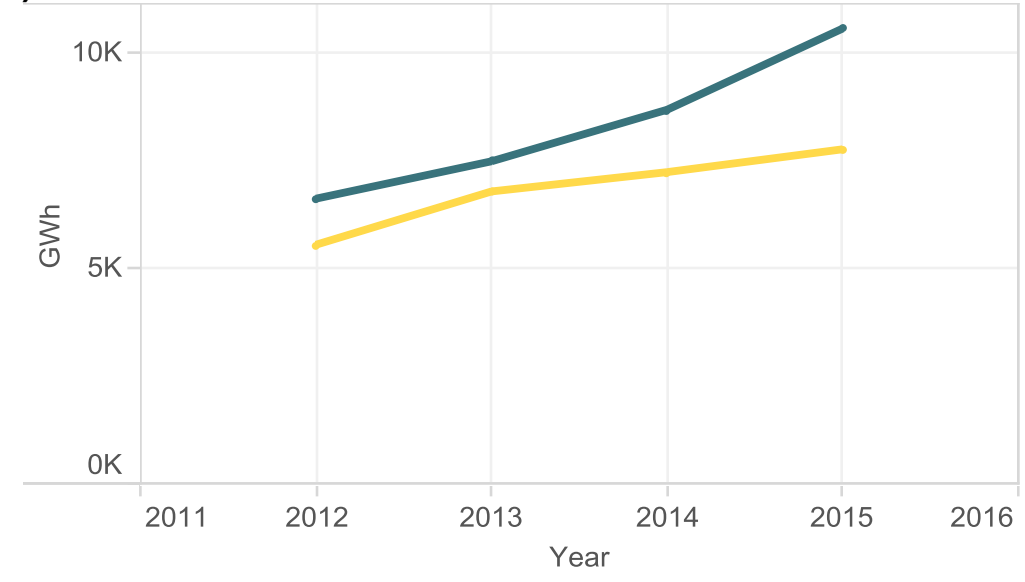

Measure Names

CoSS gross gener.. $\quad$ TANESCO gross ..

The generation revenue requirement estimate from CoSS (capacity cost and energy cost), averaged over gross demand, is compared to the TANESCO value (the sum of EPP, purchased electricity, own generation cost, and depreciation, averaged over gross demand) (Figure 32). It can be seen that the generation segment cost estimate of TANESCO is significantly higher than that from the CoSS for 2013 and 2014. The difference can be traced to a more optimistic assumption of hydrology in the CoSS (statistically available hydrology rather than low hydrology which has been experienced by Tanzania since 2011), which has implications for the load factors of thermal generators and consequent fuel consumption. This difference is recognized by EWURA, which adjusted the utilization of hydro plants to reassess the generation cost estimates originally presented by the CoSS (EWURA, 2013). The costs of EPPs procured increase the anticipated unit generation cost by about 50 $\mathrm{TZS} / \mathrm{kWh}$. 

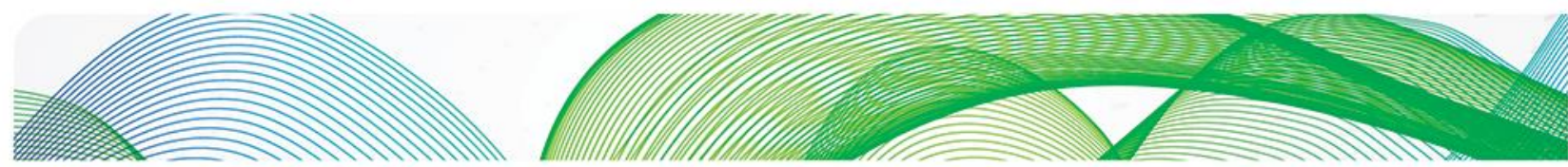

O는

Figure 32: Comparison of generation segment revenue requirement (Own analysis based on data from: AF-Mercados, 2013; TANESCO, 2013) ${ }^{22}$

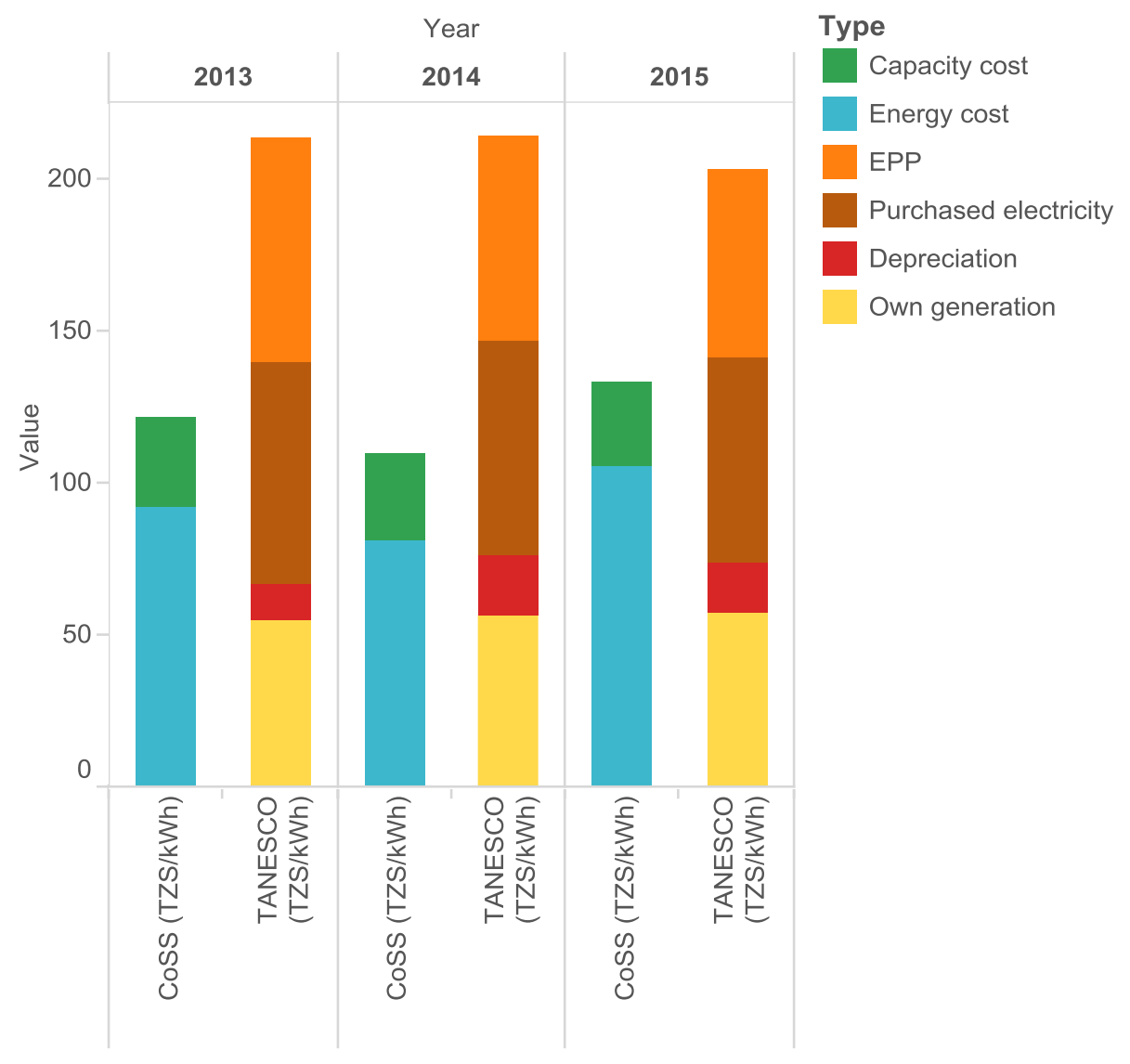

Although TANESCO refers to the payments made to other power generators as operating expenses, which in principle are to be fully recovered if prudently incurred, these payments actually include capacity payments as well as energy payments. The former is supposed to have been calculated to provide compensation for IPP and EPP investments. However, as outlined in the beginning of this section, the PPAs have not been reviewed by EWURA. Given that the track record of TANESCO in negotiating and paying for IPPs is not faultless, especially in the case of IPTL, the extent to which these charges can be considered prudently incurred, and thus passed on to end-users, is debatable. Figure 33 is a comparison of IPTL variable cost to that of Songas and other generating plants. Variable costs include fuel consumption expenses, variable O\&M costs, as well as capacity charges from PPAs. It can be seen that the IPTL capacity charge, the non-fuel portion of its variable cost, is much higher than that of any other generator.

\footnotetext{
${ }^{22}$ The exchange rate used to covert USD to TZS is 175 TZS/USD (2012 average rate).
} 

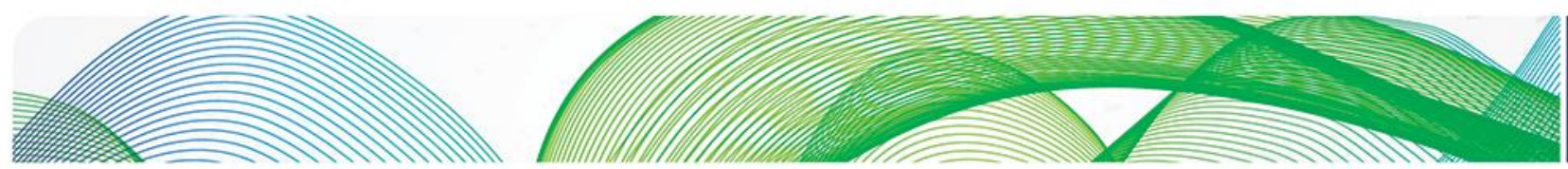

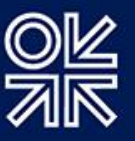

Figure 33: Comparison of variable costs of different generating plants (Data source: AFMercados, 2013, all historical EPPs are included)

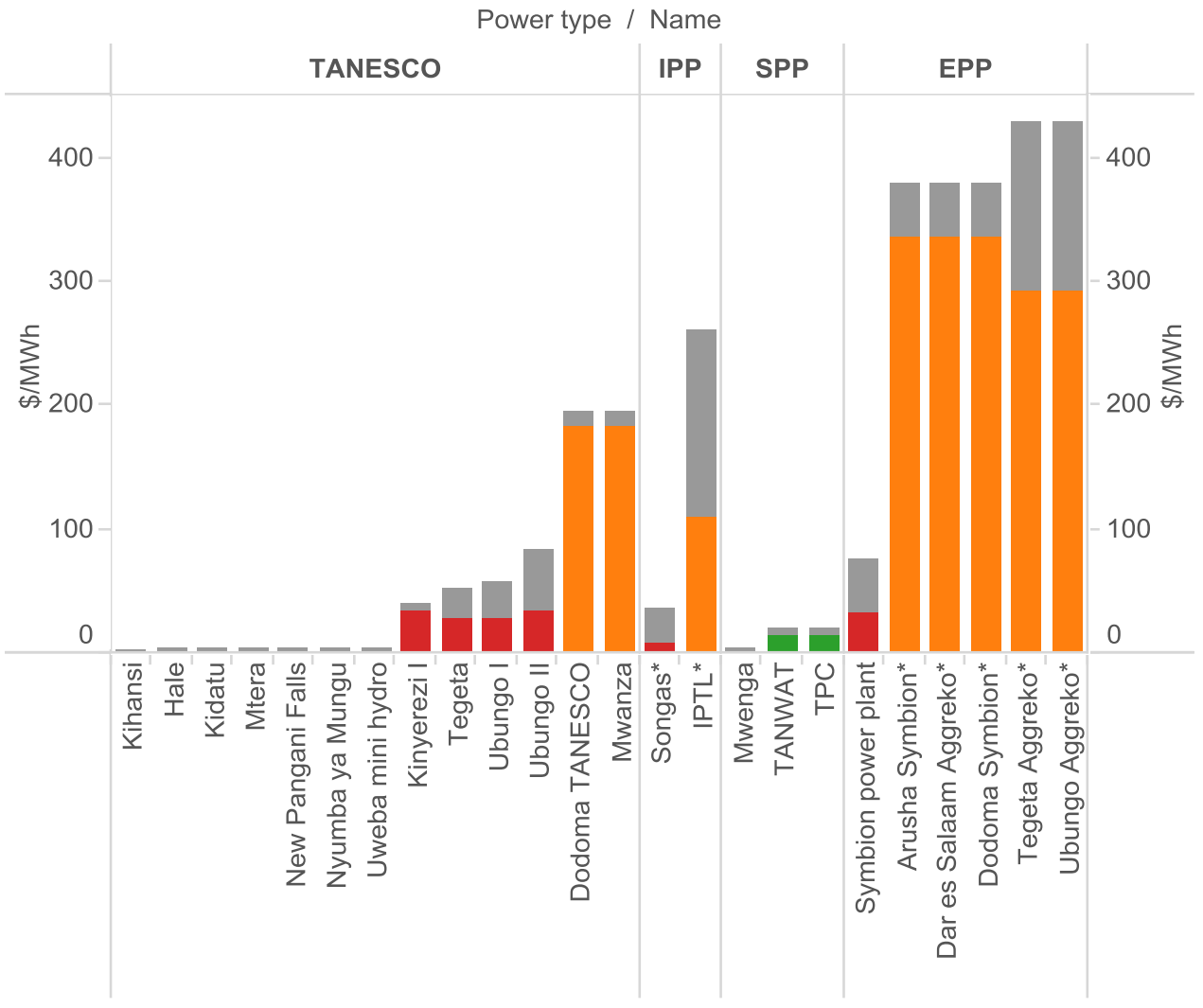

* Variable cost from these plants have incorporated the capacity charges from their PPA.

Fuel cost

Biomass

Gas

Hydro

Oil

In the CoSS, the transmission segment revenue requirement consists of two main components: capital expenditure and the operating expenditure. The transmission segment revenue requirement is assumed to be equivalent to the PSMP estimates, and the operating expenses are assumed to be 2 per cent of the new replacement value of the transmission segment rate base. As for the distribution segment, the revenue requirement for capital expenditure includes network expansion, renewal, and loss reduction allowance, while the operating expenditure revenue requirement includes staff salary and other overheads, benchmarked against international references. Since TANESCO's nongeneration operating expenses and investment plan (CIP) is not disaggregated between transmission and distribution, the CoSS revenue requirements for both network segments are summed and compared to the ones presented in TANESCO's tariff application (Figure 34). ${ }^{23}$

\footnotetext{
${ }^{23}$ Since network maintenance is counted toward capital expenditure in the CoSS, the repair and maintenance cost in the TANESCO application is assigned to the CAPEX rather than the OPEX component.
} 

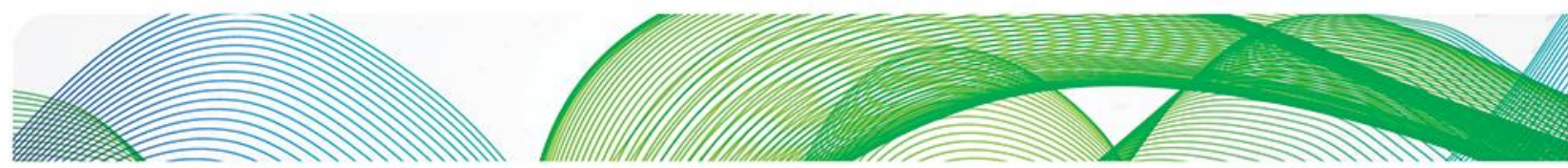

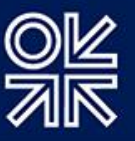

Figure 34: Comparison of transmission and distribution segment revenue requirement (Data source: AF-Mercados, 2013; TANESCO, 2013) ${ }^{24}$

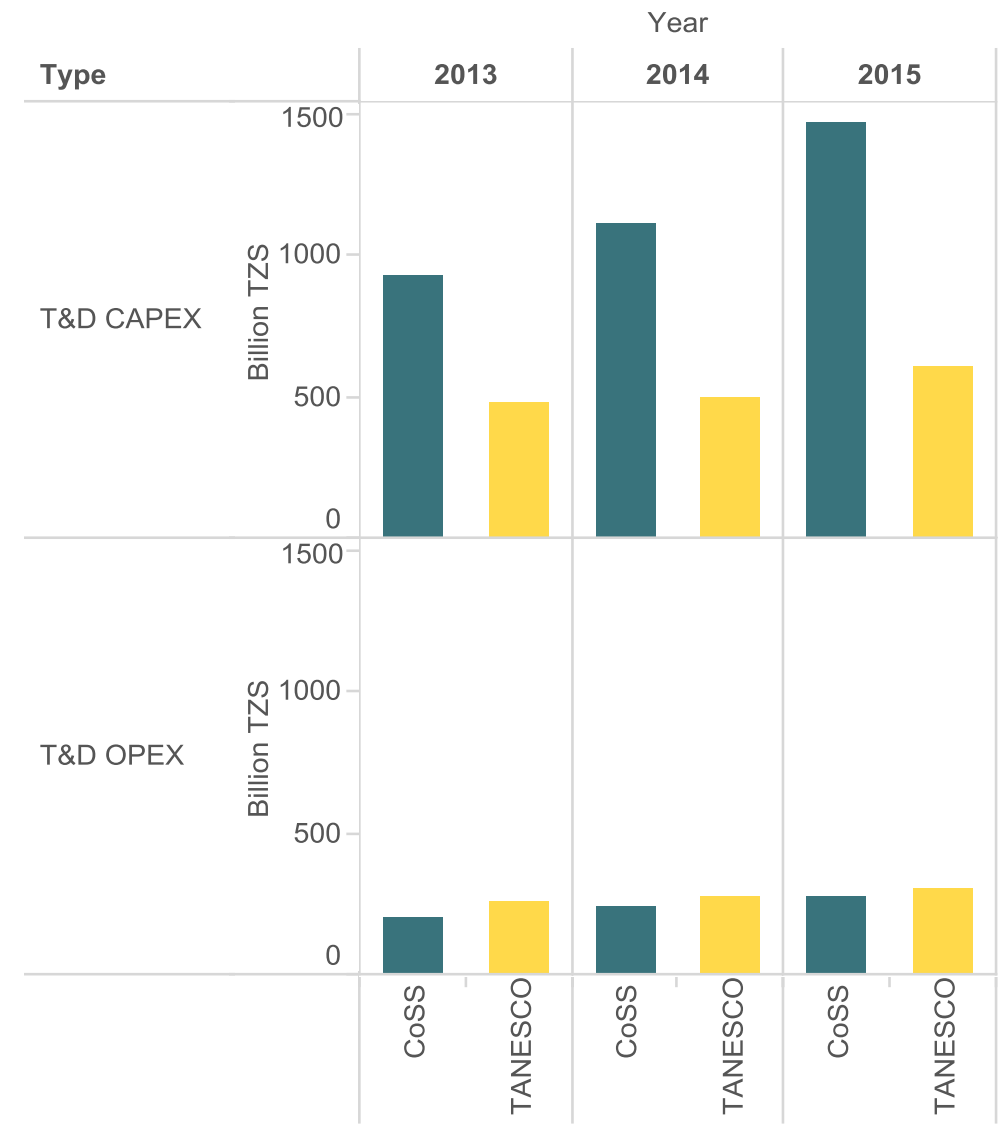

Unlike generation costs, which are subject to important external uncertainties, revenue requirement by the network segments should be relatively predictable. The operating expenditure estimated by the CoSS is slightly but consistently below that provided in TANESCO's tariff proposal, while the capital expenditure estimated by the COSS is significantly above the CIP planned by TANESCO. This suggests that there is some slim margin for improvement in TANESCO's network operations and other administrative overheads, and that the utility is not making as much investment as expected in order to serve future demand. It should be noted that REA is funding much of the distribution network expansion in rural areas. This might offset part of the difference in planned network investment.

'Loan repayment' and 'revenue from other sources' are two components which are not directly established in the CoSS but do figure in the revenue requirement of TANESCO.

The deduction of other sources of revenue, including government revenue grants, from the revenue requirement is consistent with the legislated principle that the costs covered by such revenue shall

\footnotetext{
${ }^{24}$ TANESCO revenue requirement for the years 2011 and 2012 are based on historical data, and the exchange rate used to covert USD to TZS is 175 TZS/USD (2012 average rate).
} 

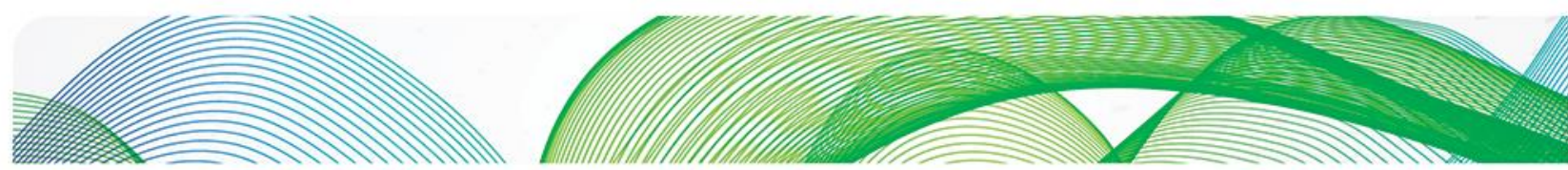

일

not be reflected in the revenue requirement. The EWURA-approved revenue requirement formula should be adjusted to incorporate such revenues.

For the 'Ioan repayment' component, it was previously established that levying funds for loan repayment as planned by TANESCO via the revenue requirement can be seen as the collection of return on debt. Therefore, the loan repayment levy proposed by TANESCO is compared to the best approximate of the debt-funded portion of the rate base (Figure 35).

$$
R B_{\text {debt }}^{\prime}=D \frac{A_{\text {fixed }}}{A_{\text {current }}+A_{\text {fixed }}}
$$

$\mathrm{RB}_{\text {debt }}^{\prime}$ : Estimate of debt-funded rate base

D: Forecasted total liabilities

$\mathrm{A}_{\text {current }}:$ Forecasted current assets

$\mathrm{A}_{\text {fixed }}:$ Forecasted fixed assets

Figure 35: Comparison of planned loan repayment with expected utility liabilities (Data source: TANESCO, 2013)

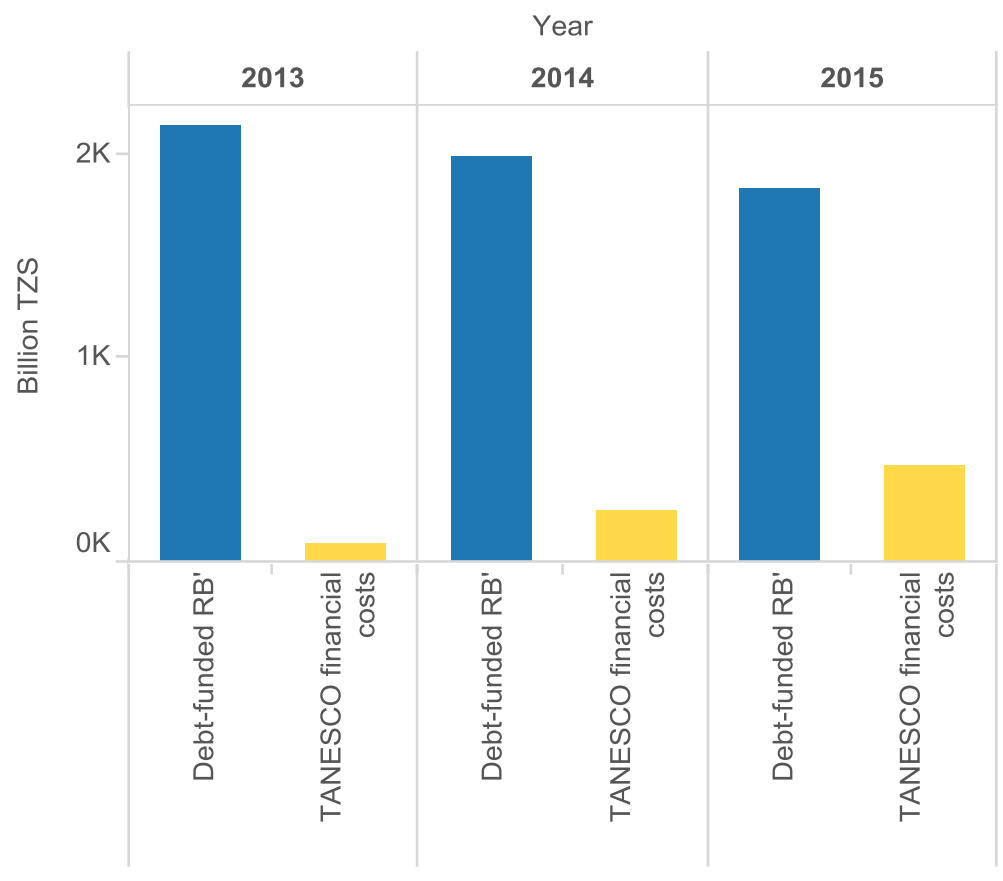

The loan repayment to be levied via tariff increases as the expected debt-funded rate base decreases, meaning that the equivalent cost of debt paid by the tariff increases with time. The equivalent cost of debt thus collected grows from 4 per cent to 25 per cent between 2013 and 2015, becoming significantly higher than the after-tax cost of debt determined by the CoSS (11 per cent). 

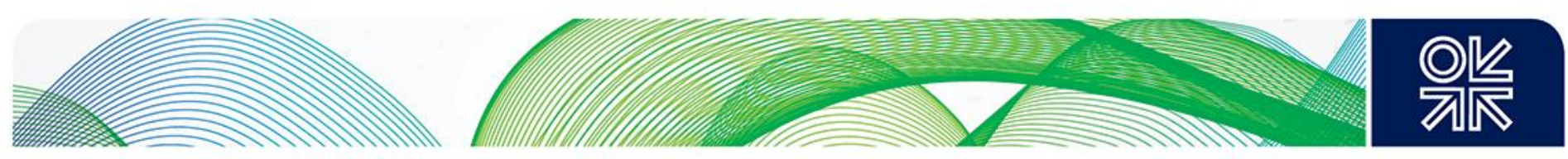

\section{Comparison with approved revenue requirement}

EWURA published the approved tariff levels but not the approved revenue requirement from which they were derived. The approved revenue requirement was thus inferred from the tariff levels in the next section and then compared to the original revenue requirement proposed by TANESCO.

In response to TANESCO's request for fuel cost, inflation, and foreign exchange adjustment, EWURA announced that the utility's proposal lacked some key regulatory monitoring parameters, such as the heat rates (efficiency ratings) of thermal power plants. Therefore, it will be using the Fuel Adjustment and Foreign Exchange Rate Fluctuation Adjustment that was established in the Rule 7(2) of Electricity (Tariff Setting) Rules, 2013 (EWURA, 2013). In 2014, after the first review of tariff adjustment, applying fuel cost and foreign exchange indexation, EWURA decided that a reduction of planned revenue requirement for 2014 was due, given decreased generation in the thermal plants (EWURA, 2014). However, given that TANESCO's financial status further deteriorated between 2013 and 2014, quarterly tariff adjustments for the year were deferred until 2015.

\section{Tariff structure and allocation}

Independently of the revenue requirement proposed by TANESCO, the tariff structure proposed in its tariff application and the EWURA approved tariff are evaluated in terms of efficiency, sufficiency, equity, and stability.

The structure of the Tanzanian electricity tariff has remained fixed since at least 2006. It does not differentiate between different geographic regions of the country or different consumption periods. The five categories of customers are differentiated based on the voltage at which they are connected and their average level of consumption. The tariff applicable to each class of customers can include an energy charge, a capacity charge, and a service charge:

1. Domestic low usage tariff (D1): this category covers domestic customers with low consumption at low voltage $(230 \mathrm{~V})$. The first $50 \mathrm{kWh}$ of consumption is charged at a subsidized lifeline rate, and monthly consumption exceeding that is charged at a higher rate and capped at $283 \mathrm{kWh}$. This tariff only contains an energy component. In the tariff approved for 2014, the lifeline consumption block has been increased to $75 \mathrm{kWh}$.

2. General usage tariff (T1): this category covers customers from a wide range of sectors, with average consumption above $283 \mathrm{kWh}$ per month, supplied at low voltage ( $230 \mathrm{~V}$ for single phase and $400 \mathrm{~V}$ for three phase). There is both an energy component and a fixed component in this tariff.

3. Low voltage maximum demand usage tariff (T2): this category covers customers with monthly average consumption of more than $7,500 \mathrm{kWh}$ at $400 \mathrm{~V}$. Energy, demand (capacity), and fixed components all exist for this tariff.

4. Medium voltage maximum demand usage tariff (T3-MV): this category covers customers connected to the grid at $11 \mathrm{kV}$ and above. Energy, demand (capacity), and fixed components all exist for this tariff.

5. High voltage maximum demand usage tariff (T3-HV): this category covers customers connected to the grid at $132 \mathrm{kV}$ and above. Energy and demand (capacity) components exist for this tariff. The fixed component was abolished in the tariff approved for 2014. It is also known as the bulk tariff (T5).

The tariff levels proposed by TANESCO are presented in Figure 36, Figure 37, and Figure 38, shown alongside the evolution of approved tariff levels. 

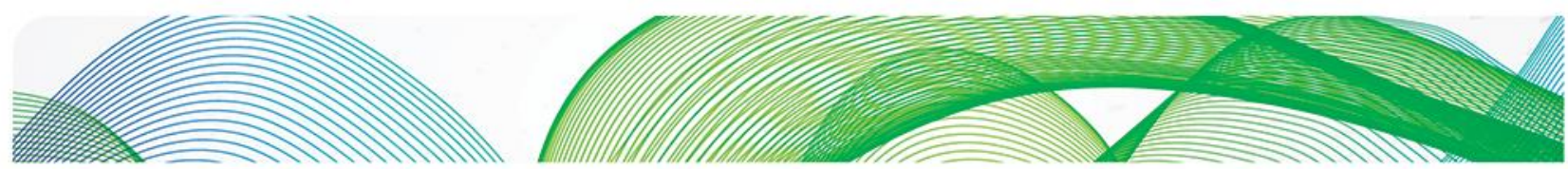

O는

Figure 36: Evolution of tariff energy charge in Tanzania (Data source: EWURA, 2012a, 2013; TANESCO, 2013)

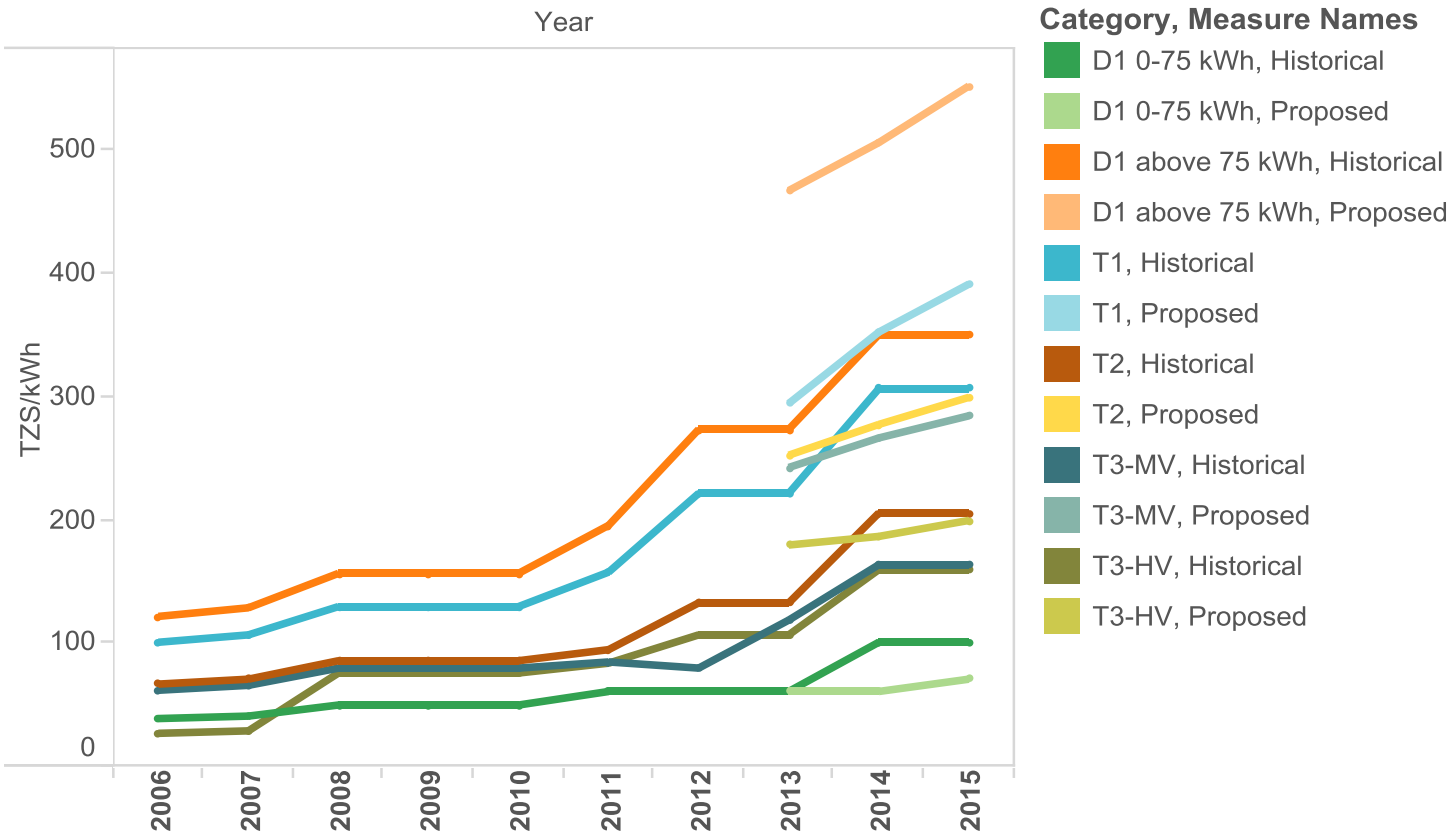

Figure 37: Evolution of tariff capacity charge in Tanzania (Data source: EWURA, 2012a, 2013; TANESCO, 2013)

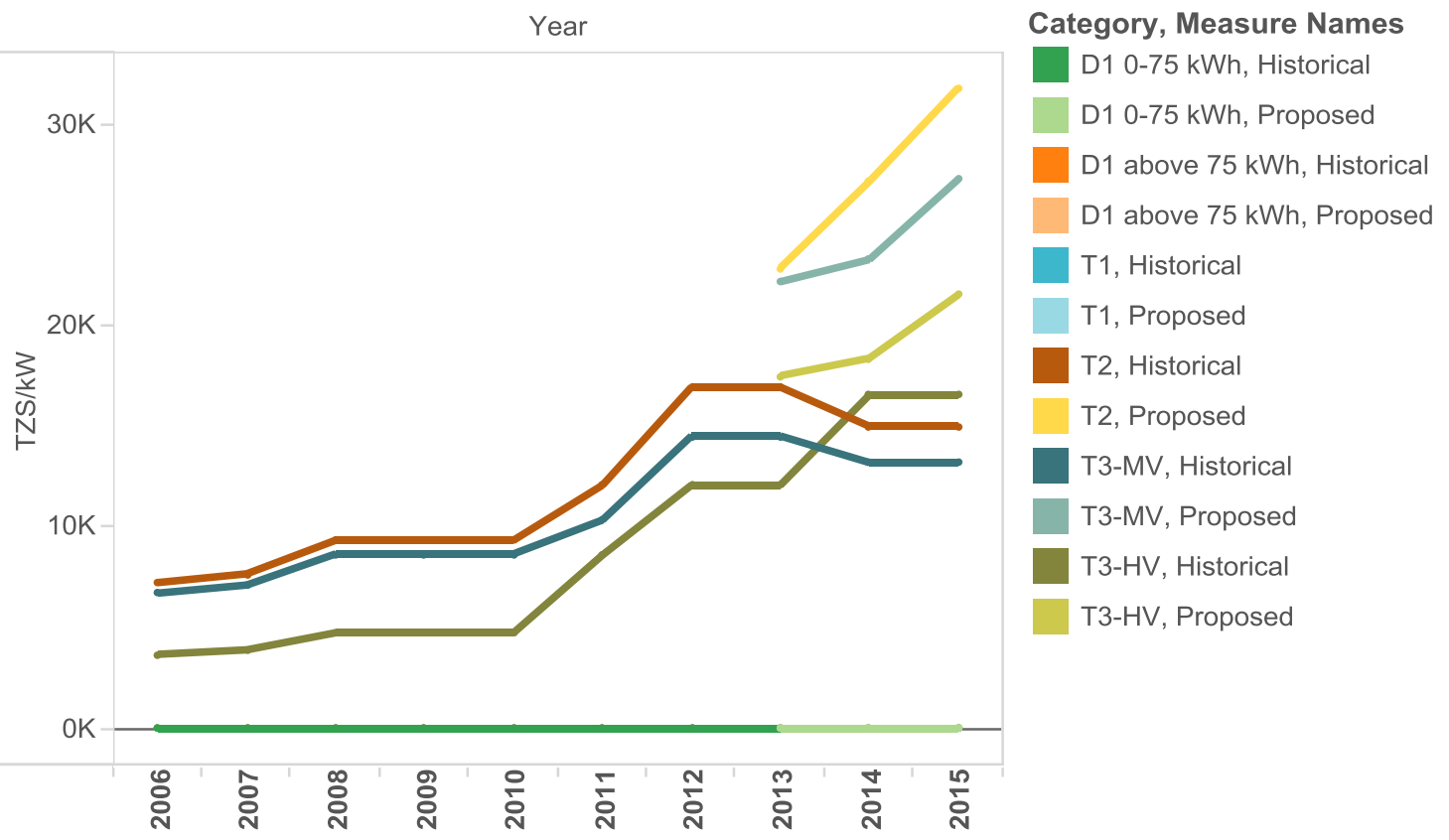



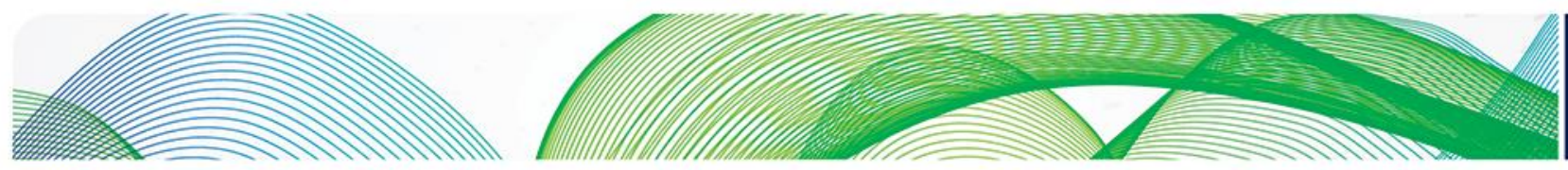

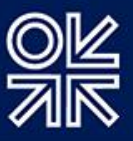

Figure 38: Evolution of tariff service charge in Tanzania (Data source: EWURA, 2012a, 2013; TANESCO, 2013)

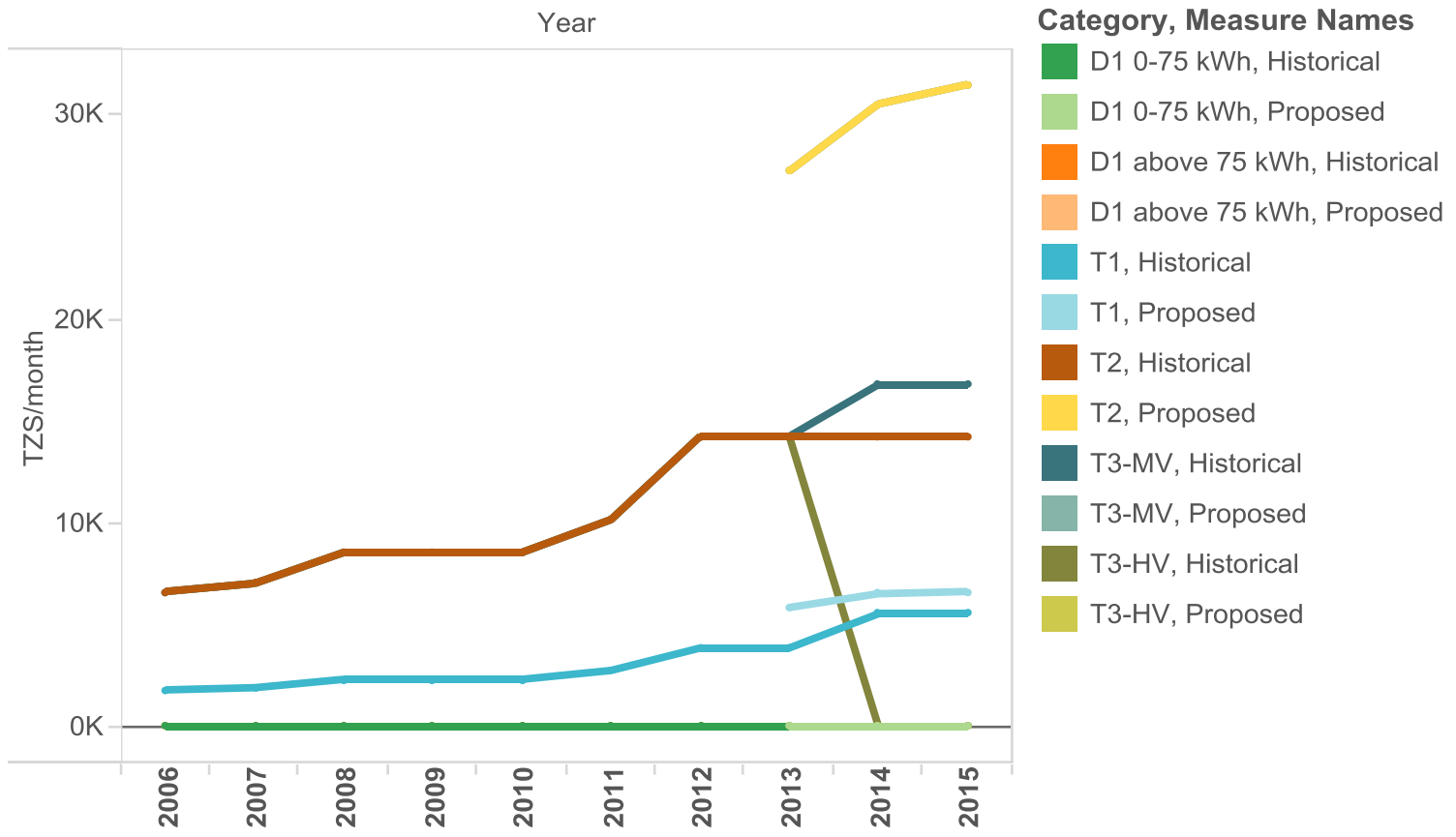

\section{Tariff sufficiency}

Before inferring the approved revenue requirement from approved tariff levels, the proposed tariff levels need to be checked for tariff additivity. Based on assumptions in Appendix III, the proposed tariff levels are converted to equivalent revenue requirement. It is found that the tariff design is additive, given the demand forecast available in ex post terms: if applied, the tariffs collected in year $t$ will yield collected tariffs whose sum matches the revenue requirement for year $t-1$ (Figure 39).

The tariff levels approved by EWURA are applied to the same demand forecasts as the ones used for the additivity check, and the resulting tariff billed is compared to TANESCO's proposed revenue requirement (Figure 40). It is inferred that the revenue requirements approved by EWURA are those related to operating expenses: the estimated sum that can be charged using the approved tariff for 2014 is roughly the magnitude of the estimated operating expenses for 2013 (1,480 billion TZS vs. 1,410 billion TZS). The same observation applies for the subsequent year (1,608 billion TZS vs. 1,525 billion TZS). This is consistent with the historical trend noted in Figure 25 for the period prior to 2011. 

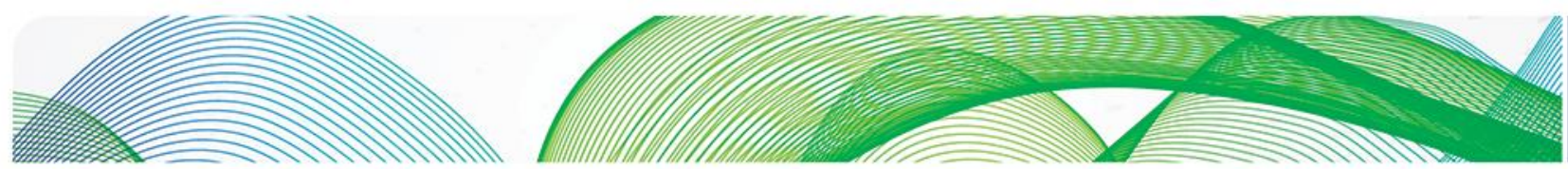

이조

Figure 39: Comparison of the estimates for proposed tariff charged to customers and for TANESCO's revenue requirement (Own analysis based on data from: EWURA, 2013;

TANESCO, 2013)

Estimated tariff charge

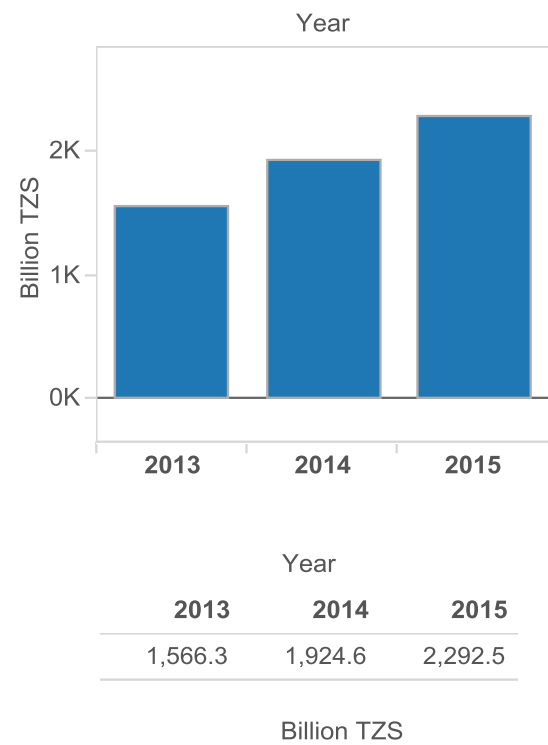

Item (group)

Financial costs

TANESCO CIP

Depreciation
Revenue requirement

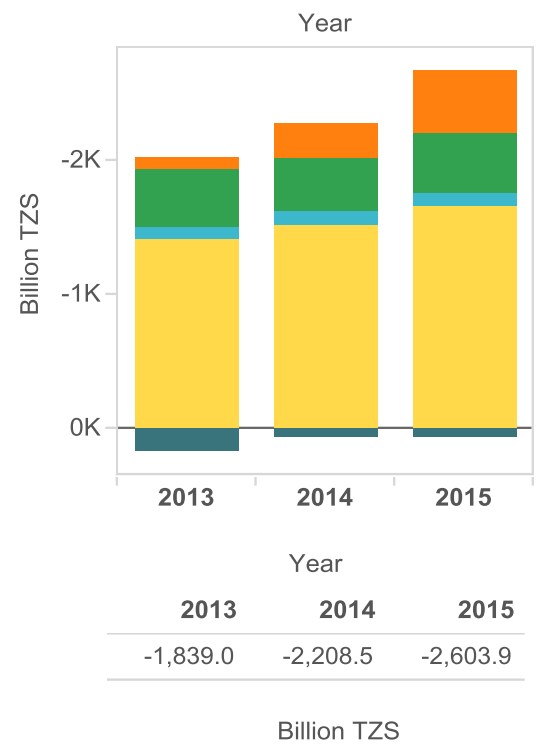

Other revenue

Operating expenses 

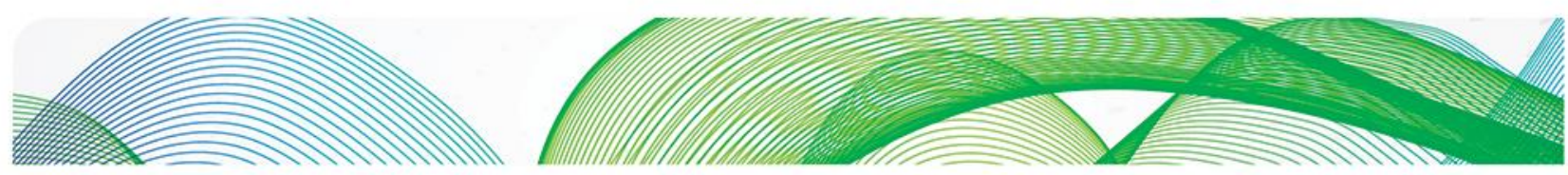

䢰

Figure 40: Comparison of the estimates for approved tariff charged to customers and for TANESCO's revenue requirement (Own analysis based on data from: EWURA, 2013; TANESCO, 2013)

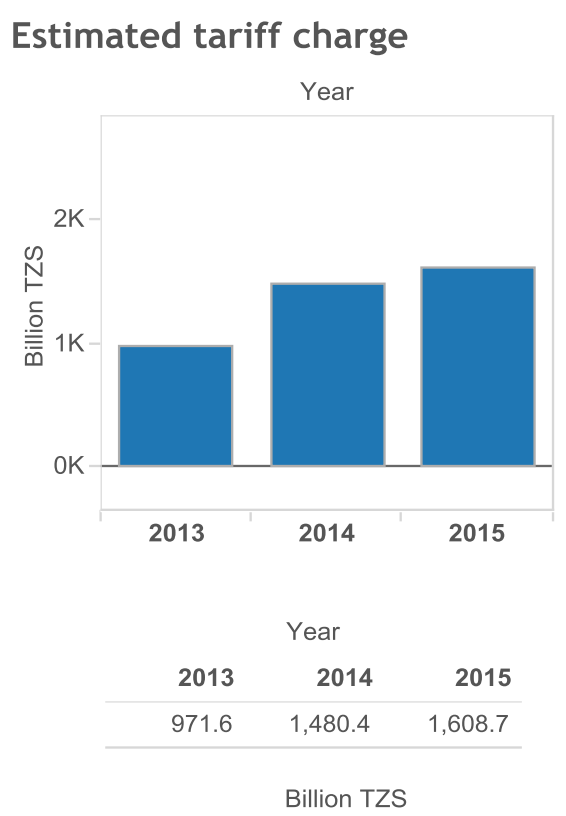

Item (group)

Financial costs

TANESCO CIP

\section{Revenue requirement}

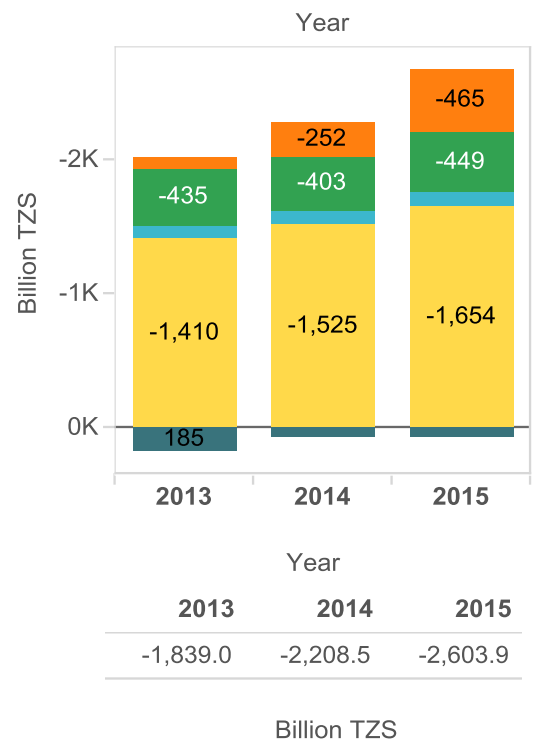

Other revenue

\section{Tariff efficiency}

The average price of electricity per kWh consumption (including the effect of energy, capacity, and service charges) is plotted for different categories of customers as a function of their monthly consumption under the newly approved tariff, in Figure 41. For all costumer classes but one, the average cost of electricity decreases with monthly consumption, then rapidly stabilizes. For ratepayers in category $\mathrm{D} 1$, exceeding the lifeline consumption quota leads to a steep increase in average cost of electricity. This increase eventually stabilizes once monthly assumption exceeds $1,000 \mathrm{kWh}$. For consumption below $200 \mathrm{kWh}, \mathrm{D} 1$ is the most advantageous customer class, but it becomes the most expensive once monthly consumption is above $400 \mathrm{kWh}$. This incentivizes customers with average consumption above $400 \mathrm{kWh}$ to contract for a T1 tariff rather than a D1 tariff. As a special case of an increasing block design, the stepped energy charge for D1, the only customer class with such design, deters non-qualified customers from profiting from the subsidized lifeline rate. However, for users with monthly consumption between 200 and $400 \mathrm{kWh}$, there is incentive for them to remain within the D1 class to take advantage of the lifeline rate, because the average cost of power is lower than that of $\mathrm{T} 1$. 

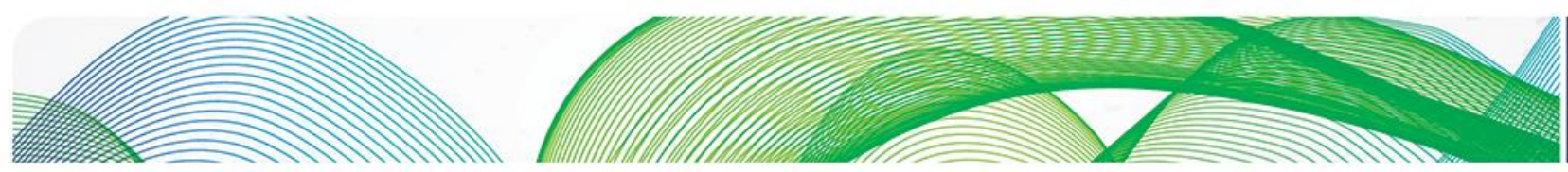

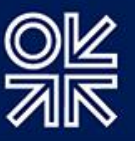

Figure 41 Average price of electricity for different categories of customers at load factor = 0.7 (Own analysis based on data from: EWURA, 2013)

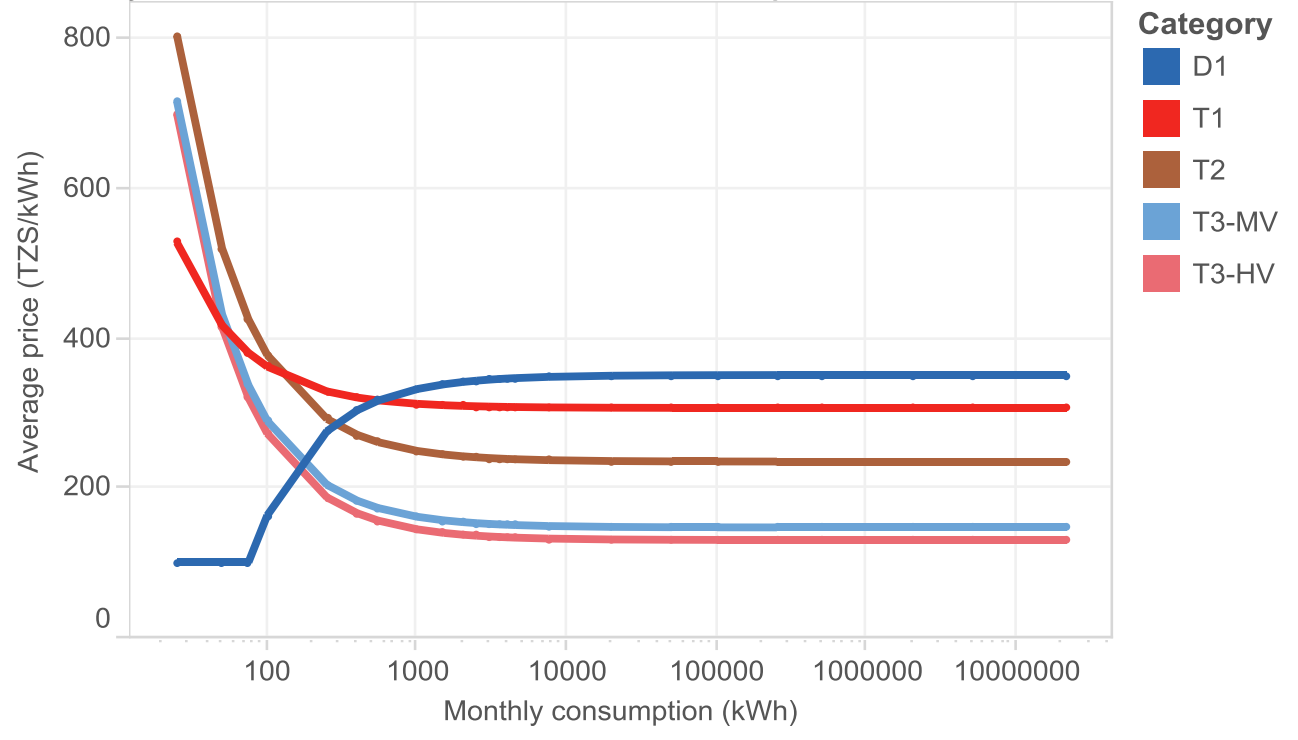

For customers belonging to categories T2, T3-MV, and T3-HV, the existence of the capacity component of tariff encourages these customers to increase their load factor (to require less network capacity for the same quantity of energy consumed) (Figure 42). In other words, spreading out energy use over a period of time rather than consuming electricity that would produce sharp profiles. In the previous section, it was noted that small incremental increases in peak demand may require the use of generation units with much higher marginal cost (requiring units fired by liquid fuel), therefore a tariff price designed to incentivize customers to curb peak demand might generate important system savings. Additional tariff features, such as time-of use-tariff, could be incorporated to further incentivize customers to curb peak demand, especially in the T3-MV class, where only a few customers are responsible for a third of overall power consumption. 

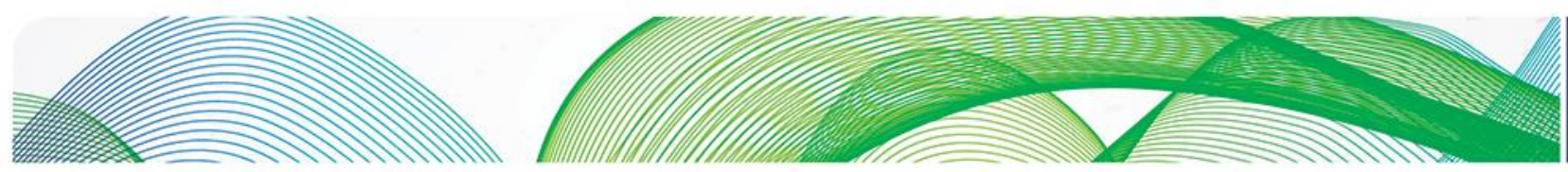

애잠

Figure 42 Average price of electricity for select categories of customers at load factor $=0.1$ and 0.9 (Own analysis based on data from: EWURA, 2013)

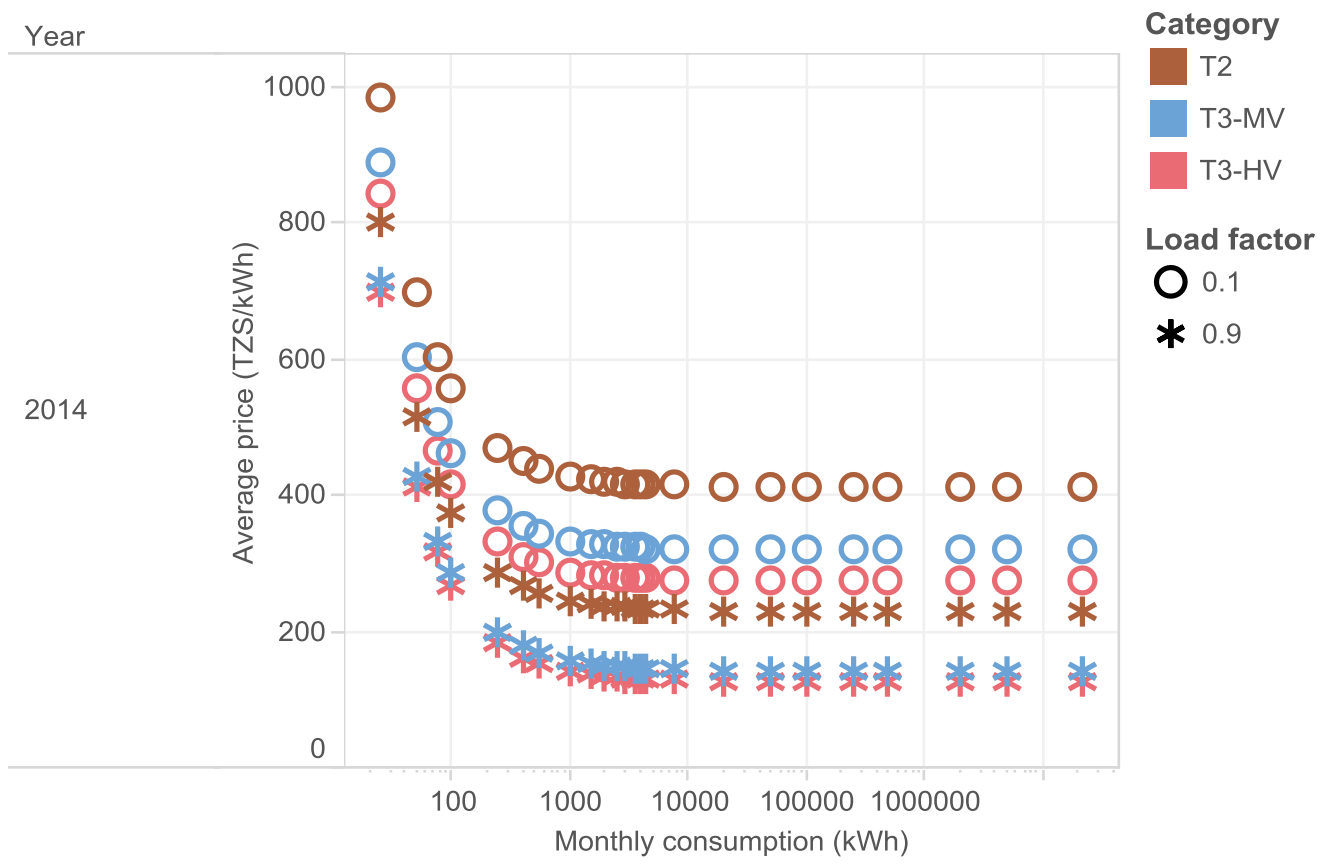

\section{Tariff equity}

To assess the equity of the cost allocation, it needs to be determined whether the tariff collected from each customer class reflects all costs (energy driven, capacity driven, and customer driven) that each class imposes upon TANESCO. EWURA uses the average cost rather than the marginal approach to allocate costs to the tariff structure (AF-Mercados, 2013; EWURA, 2012a). Conventionally, using this approach, the energy charge is used to recover generation-related costs, the capacity charge is use to recover network-related costs, and the service charge is used to recover the administrative costs of service provision. For both the tariff levels proposed and the tariff levels approved, energy components make up the majority of the sum of all bills charged to customers (Figure 43). In the case of the proposed tariff levels, the total energy charge collected exceeds generation related costs in the expected revenue requirement (yellow-coloured items), suggesting that the energy charge is used to recover other categories of costs from customers. 

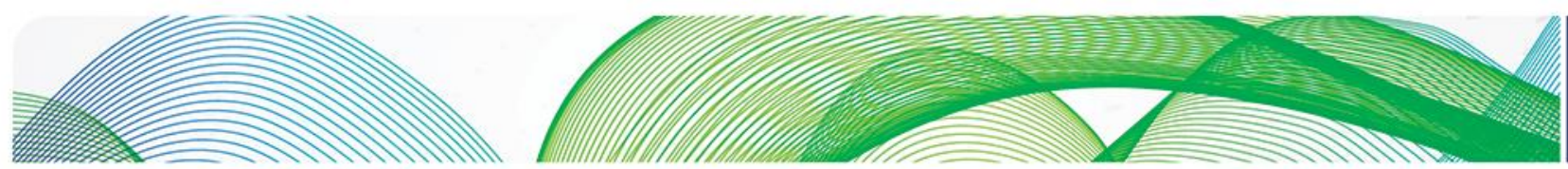

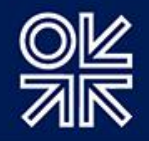

Figure 43: Contribution of different types of charges to total tariff collected (Own analysis based on data from: EWURA, 2013; TANESCO, 2013)

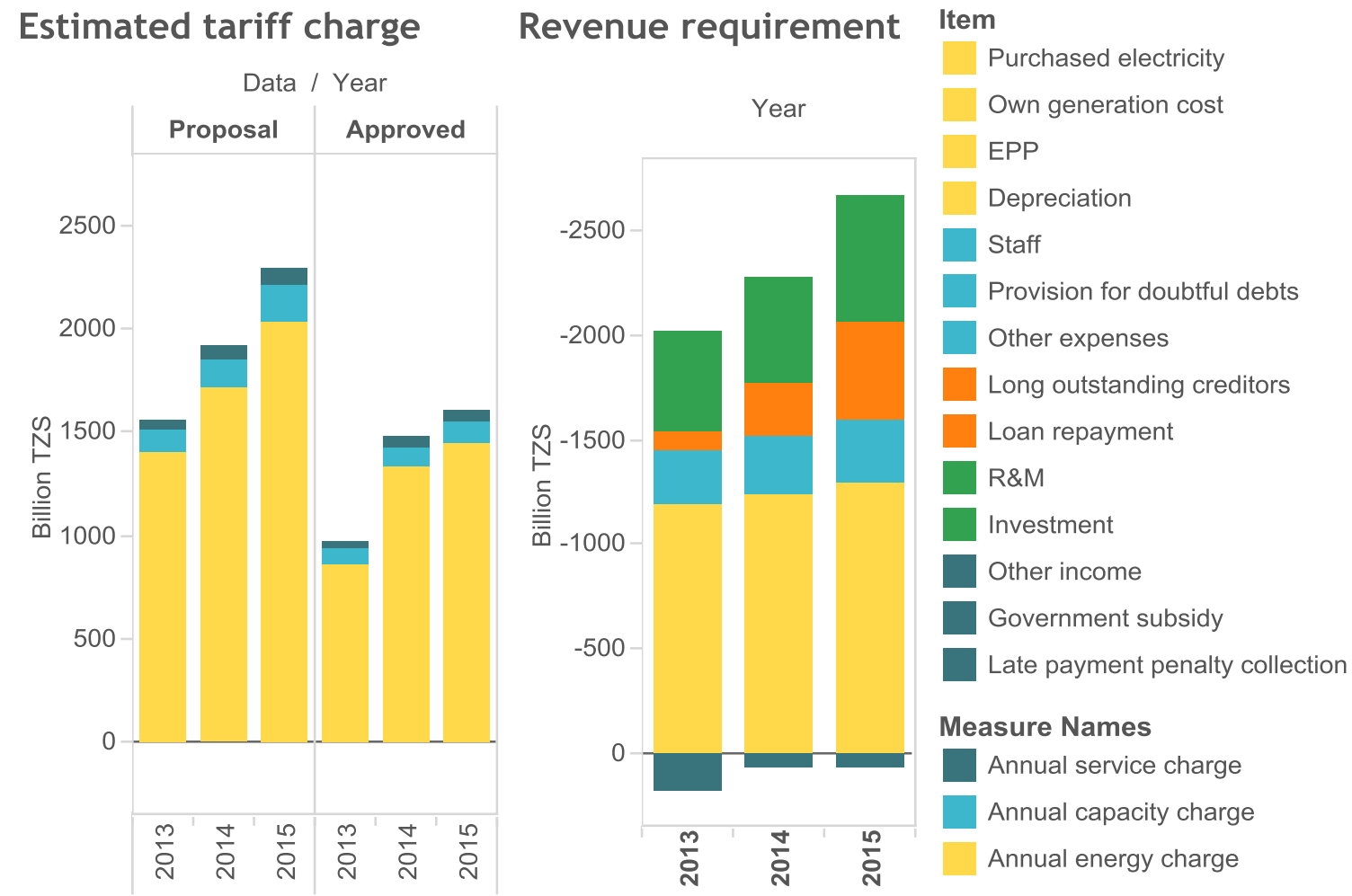

Given TANESCO did not disclose each customer class' contribution toward network cost (only the forecasted breakdown of demand per customer class is available), the share of tariff collected from each customer class under the proposed tariff is compared to its contribution to total demand, a standin for its contribution toward total costs. 

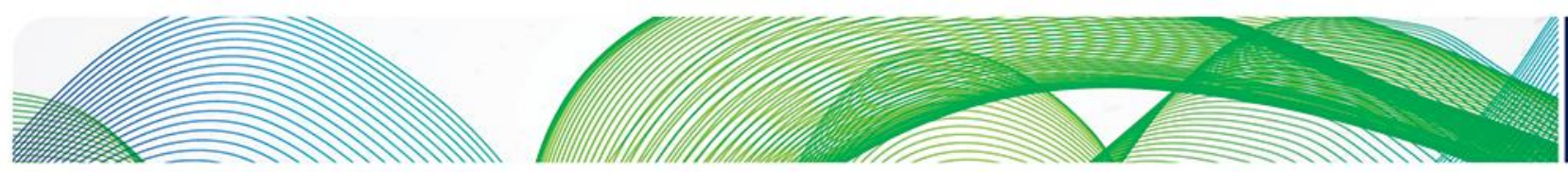

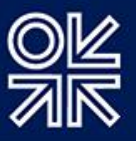

Figure 44: Comparison of customer class contribution to tariff collection and demand (Own analysis based on data from: EWURA, 2013; TANESCO, 2013) ${ }^{25}$ Share of tariff collected

\begin{tabular}{|c|c|c|c|c|c|c|c|}
\hline \multicolumn{5}{|c|}{ Year } & \multicolumn{3}{|c|}{ Year } \\
\hline Category & 2013 & 2014 & 2015 & Category & 2013 & 2014 & 2015 \\
\hline D1 < 50 kWh & $0.67 \%$ & $0.42 \%$ & $0.32 \%$ & D1 < 50 kWh & $3.19 \%$ & $2.26 \%$ & $1.67 \%$ \\
\hline D1 > 50 kWh & $5.26 \%$ & $5.68 \%$ & $6.21 \%$ & D1 > 50 kWh & $6.18 \%$ & $7.10 \%$ & $7.70 \%$ \\
\hline T1 & $44.47 \%$ & $46.61 \%$ & $46.88 \%$ & T1 & $40.07 \%$ & $40.08 \%$ & $40.07 \%$ \\
\hline T2 & $12.06 \%$ & $11.72 \%$ & $11.64 \%$ & T2 & $11.53 \%$ & $11.53 \%$ & $11.53 \%$ \\
\hline T3-MV & $32.88 \%$ & $31.33 \%$ & $30.76 \%$ & T3-MV & $32.81 \%$ & $32.81 \%$ & $32.80 \%$ \\
\hline T3-HV & $4.66 \%$ & $4.23 \%$ & $4.18 \%$ & T3-HV & $6.22 \%$ & $6.22 \%$ & $6.23 \%$ \\
\hline
\end{tabular}

D1 $>50 \mathrm{kWh}, \mathrm{T} 2$, and T3-MV customers roughly contribute the same amount to the tariff collected under the levels proposed. These levels are also consistent with their contribution toward total demand. D1 $<50 \mathrm{kWh}$ customers, bearing about 0.5 per cent of all tariffs collected, is responsible for 1-3 per cent of total demand. Correspondingly, the tariff collected from T1 customers are higher than the expected level, based on their share of total demand. Thus, the lifeline rate present can be seen as a cross-subsidy from T1 customers to D1 $<50 \mathrm{kWh}$ customers. The size of this cross-subsidy is small relative to the size of the overall sector. Interestingly, the tariff collected from T3-HV customers, under the proposed tariff levels, is also slightly under its expected shares (4 per cent vs. 6 per cent). It could be because they are charged the bulk tariff, excluding network costs given that they are connected at $132 \mathrm{kV}$. Overall, the tariff structure and levels proposed by TANESCO are aligned with different customer contributions toward total demand, except for the cross-subsidy to lifeline rate customers.

Given that the approved tariff levels have changed the cost recovery allowed from each customer class from the one proposed by TANESCO, an approximately equitable distribution, it is also necessary to analyze their impact on outcome equity. In Figure 45 the total revenue collected from all customer classes over 2013-15, compared to TANESCO's initial proposal, is shown to have decreased under the approved tariff. The only exception is in the energy charge collected from D1 $<50 \mathrm{kWh}$ customers, which increased under the approved tariff (from 26 to 34 billion TZS). However, the degree to which tariff collection is cut back from the proposed level is different for different classes: approved revenue to be collected from T1 customers is 80 per cent of the proposed amount, while approved revenue to be collected from T3-MV customers is 55 per cent of the proposed amount. Such unevenness across the approved tariff leads to a cost distribution among users that is different from that proposed. Relatively more costs are borne by T1 customers and less by T3-MV customers under the approved tariffs (Figure 46).

\footnotetext{
${ }^{25}$ The effect of increasing the lifeline rate allowance from $50 \mathrm{kWh}$ to $75 \mathrm{kWh}$ for D1 customers is neglected.
} 

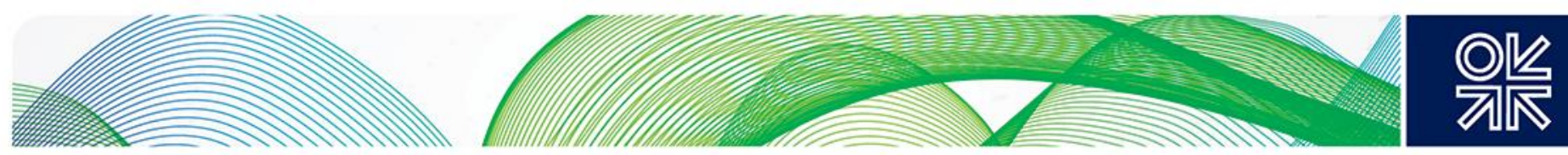

Figure 45: Comparison of proposed and approved tariff charges to be collected 2013-15 (Authors' analysis based on data from: EWURA, 2013; TANESCO, 2013)

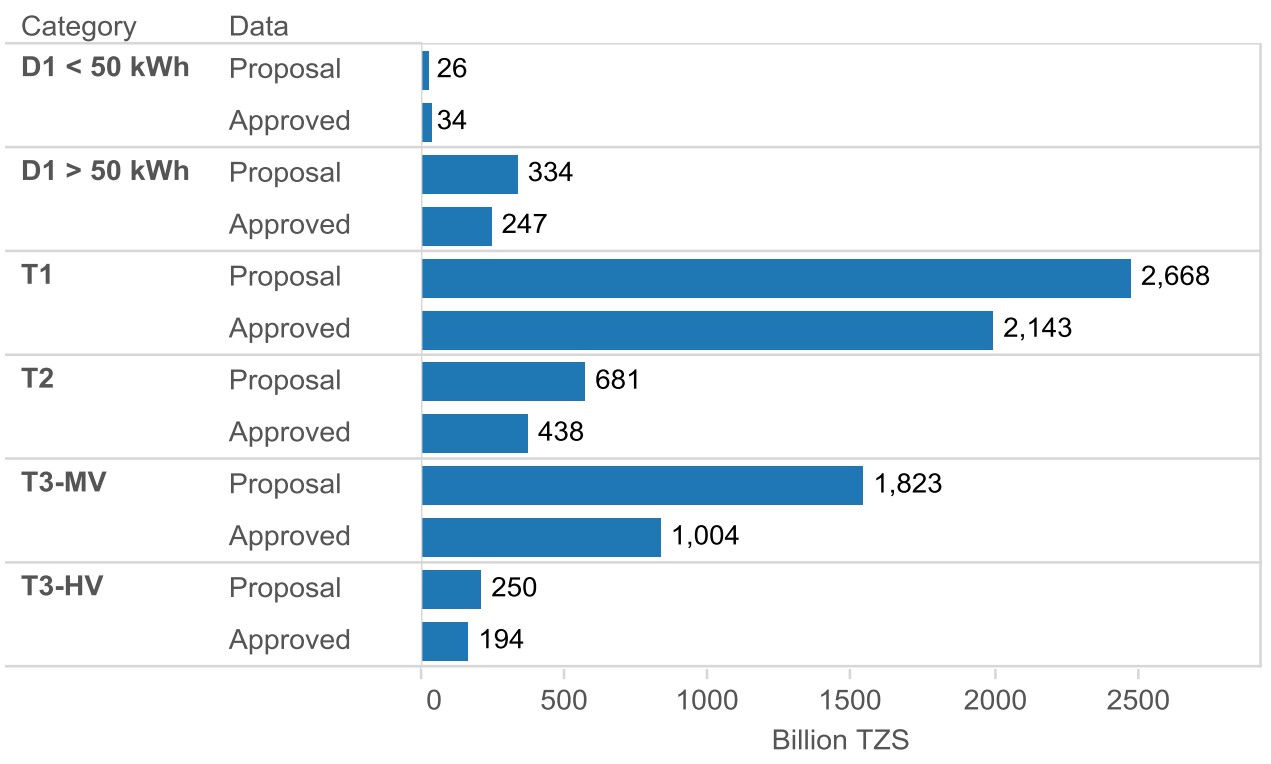

Figure 46: Comparison of customer class contribution to tariff collection under proposed and approved tariffs (Own analysis based on data from: EWURA, 2013; TANESCO, 2013)

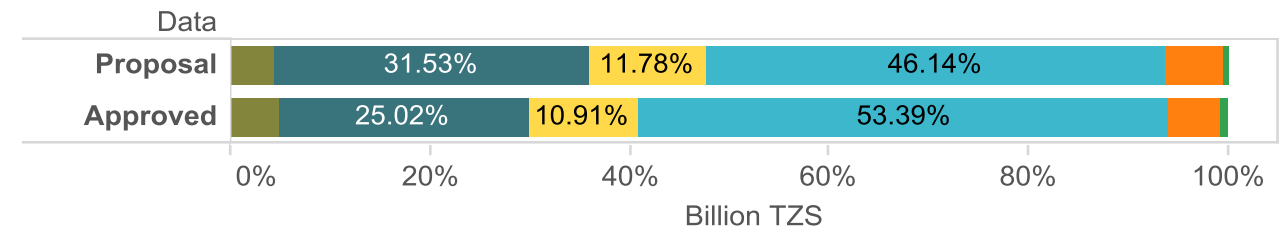

\begin{tabular}{l|l|l}
$\begin{array}{l}\text { Category } \\
\text { T3-HV }\end{array}$ & T2 & D1 $>50 \mathrm{kWh}$ \\
T3-MV & T1 & D1 $<50 \mathrm{kWh}$
\end{tabular}

\section{Tariff stability}

Since 2007, EWURA has always rejected TANESCO's proposed tariff increases and approved lower ones. Overall, the year-to-year increase has never exceeded 40 per cent. However, the overall trend has been for a consistently increasing tariff. Given that the energy charge is the most important component of all electricity bills collected (Figure 43), the relative change of the energy component of the historically approved tariffs for different customer classes is used as a proxy for the relative change in electricity bill for different classes (Figure 47). 

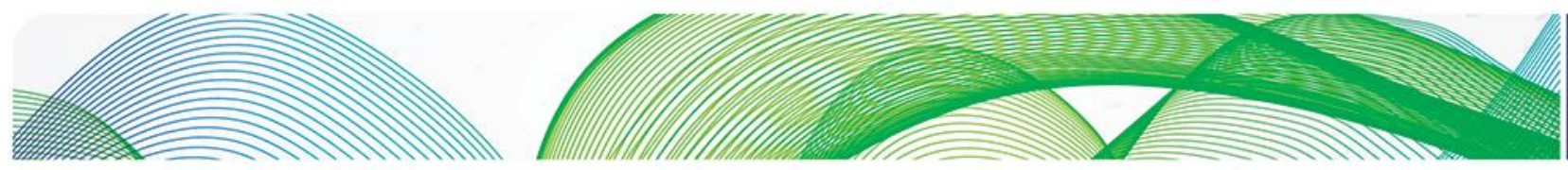

O는

Figure 47: Relative change in the energy charge for various customer classes since 2006 (Own analysis based on data from: EWURA, 2012a, 2013; TANESCO, 2013)

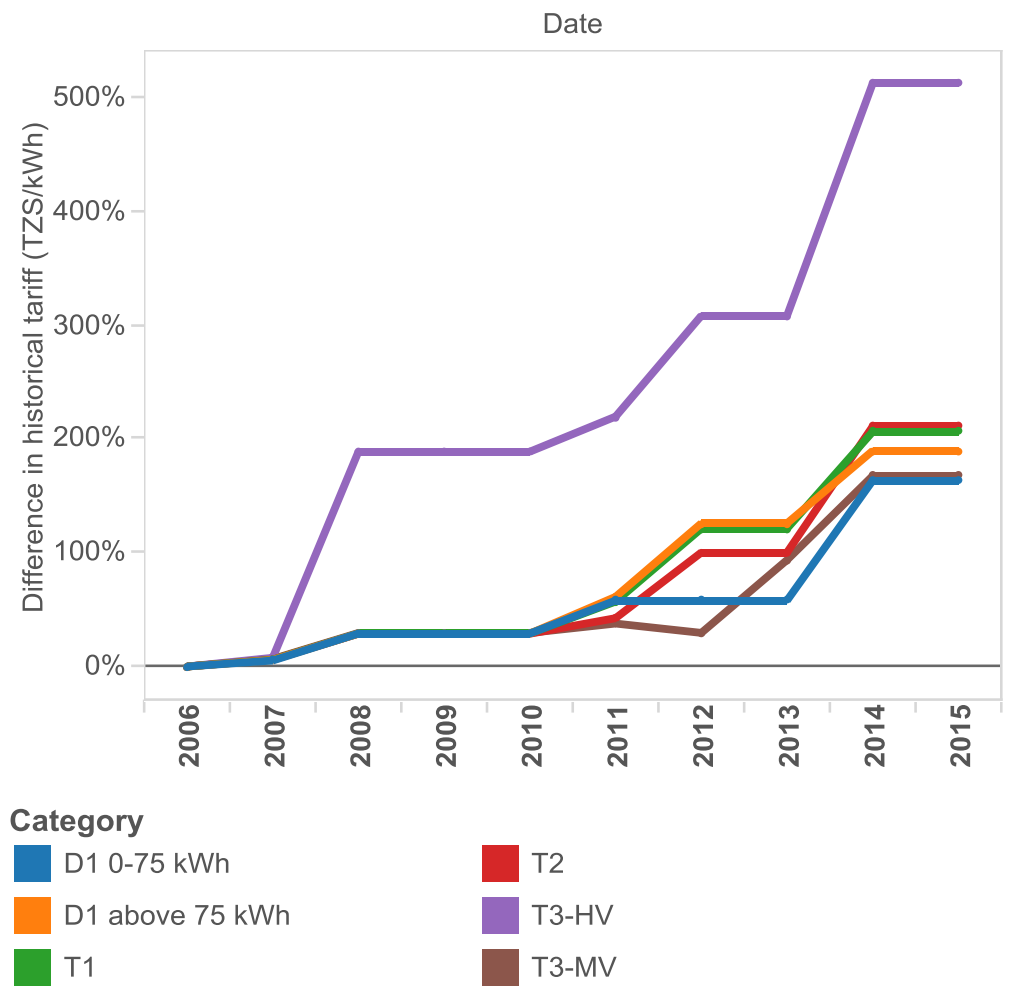

The energy charge for T3-HV class customers has changed the most since 2006, by 500 per cent, while the increase for all other customers are limited to between 163 per cent and 210 per cent. The increase in tariff for D1 <lifeline threshold customers and T3-MV lag behind that for the other classes. This is probably due to concerns over the ability of economically vulnerable customers to afford electricity and with the competitiveness of Tanzanian industries (especially the more electricity intensive ones).

EWURA's approval of new tariffs for 2014 and onward included a requirement for EWURA to adjust TANESCO's tariffs on a quarterly basis to reflect changes in fuel costs and fluctuations in foreign currency exchange rates. The effect of inflation is also to be considered by EWURA every six months. This occurred despite the Government Consultative Council's comment, during the stakeholders consultation process, that indexation will make tariffs unpredictable (EWURA, 2013). This suggests that the regulator is willing to pursue tariff sufficiency with some cost to tariff stability. In application, however, the approved tariff has not yet been adjusted. In 2014, after the first tariff adjustment evaluation, EWURA decided that tariff reduction due to decreased fuel use in thermal generation would be deferred until 2015, given TANESCO's deteriorating financial position. This demonstrates that the implementation of tariff indexation is far from automatic, and that the regulator's deliberation still prevails. 

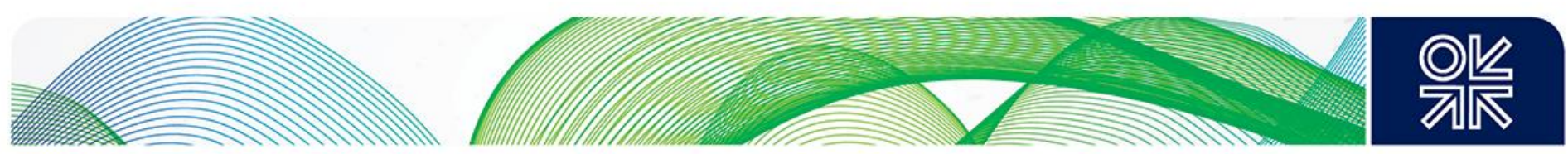

\section{Discussion}

Having examined the current practice of integral tariff setting, the paper now presents observations on the process of tariff setting and discusses the outcome in terms of the ratemaking principle that EWURA upholds.

To begin, the formula used by TANESCO to calculate its revenue requirement in its 2013 tariff review application is different from the one specified by EWURA in its 2009 guidelines. The two formulas have in common the pass-through of operating and maintenance costs, but they have different ways of accounting for and rewarding investment in the power sector.

In EWURA's original formula, the underlying logic is that the equity and liability owners of the utility company - in TANESCO's case, the government and development banks - provide up-front funds for the planned additions to an existing asset base; therefore, the updated rate base and the recognized WACC inform the calculation of revenue requirement, based on which the company collects a return upon the capital invested. The annual revenue collected, in principle, other than covering operating expenditure, is enough to cover interest repayments and dividend payments. After that, the utility executive can make decisions to make further investment on behalf of the shareholders.

In TANESCO's formula the rate base is absent, but there is a depreciation term (supposedly calculated based on a certain book value of all existing fixed assets, a stand-in for the rate base but not shown). Consequently, a return upon the rate base cannot be determined, so loan repayment and investment are levied directly via the revenue requirement. Some type of equivalence could be drawn between the two formulae, in the case that some conditions are met (see box below). However, this inconsistency in tariff setting methodology needlessly complicates the way revenue requirement items are to be analyzed. Therefore, either EWURA or TANESCO need to revise their tariff setting guidelines/application to consolidate the formula to be used.

Investment funds directly levied from current ratepayers could be an alternative form of financing. One condition exists: the assets financed by the levy should not be included in the rate base awarded with a rate of return, should that become the method through which the future revenue requirement is calculated. In other words, if the current ratepayers were to finance the investments directly, then they (and future ratepayers) should not have to pay returns to the capital invested in those assets to TANESCO, who will be holding these assets.

As for the loan repayment levied, it could be considered to be the rate of return charged for the debt portion of the asset base. Therefore, if the sum levied is in line with the known cost of debt, then it could be justified as a reasonable cost to be passed on to the ratepayers, with the condition that the debt portion of the rate base is not receiving any other form of compensation.

Secondly, the CoSS performed by AF-Mercados presents estimated cost of service for TANESCO in terms of different industry segments: generation, transmission, and distribution. However, TANESCO did not report its revenue requirements disaggregated by segments. This makes it difficult to conduct direct comparison between the two to assess cost efficiency, making independent verification difficult. Therefore, in the future, as TANESCO progresses toward the first milestone in structural reform (accounting unbundling of generation, transmission, and distribution), the revenue requirement that it supplies in its tariff review applications should be correspondingly disaggregated. 

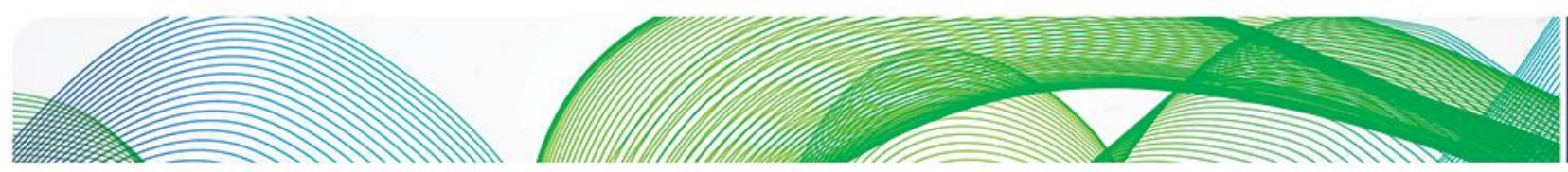

애잦

Lastly, in the tariff order published by EWURA in response to the TANESCO 2013 application, the regulator has listed the various tariff schedules approved, but not the approved revenue requirement upon which they are based. Therefore, the regulator's assessment of the appropriateness of the TANESCO tariff review application is not in the public domain. Given that the tariff application is already in the public domain, publication of the approved revenue requirement and its breakdown will increase the transparency of the rate-setting process.

\section{Economic efficiency}

Do the allowed revenues, to be recovered from ratepayers, represent efficient use of resources by TANESCO?

The computation of the revenue requirement is based on the ex ante forecast of the cost elements rather than an ex post evaluation of historically incurred costs. In principle, this incentivizes TANESCO to provide regulated services at costs lower than those approved.

It is found that the generation-related costs are highly sensitive to generator availability assumptions. The availability of different types of generation capacity is a parameter that has high sensitivity in forecast outcomes, given that the supply stack of installed capacity in Tanzania has a three-tier structure: very low variable cost hydro forms the first tranche, followed by gas generation capacity with medium variable cost, and liquid-fuel fired generation with high variable cost (Figure 48). The availability of hydro generation is dependent on hydrology, while the availability of gas generation is dependent on gas availability, two factors which are beyond the control of TANESCO. This means that any generation revenue requirement which does not explicitly address these two exogenous uncertainties will have a high margin for error. This increases the difficulty of ex ante revenue requirement determination, which is the currently adopted method. For the same reason (tier-shaped supply stack), a small increase in incremental peak demand might lead to disproportionally higher marginal generation costs. Therefore, it is hard to assess the efficiency of generation costs unless availability and peak demand assumptions are agreed upon by the utility and the regulator. 

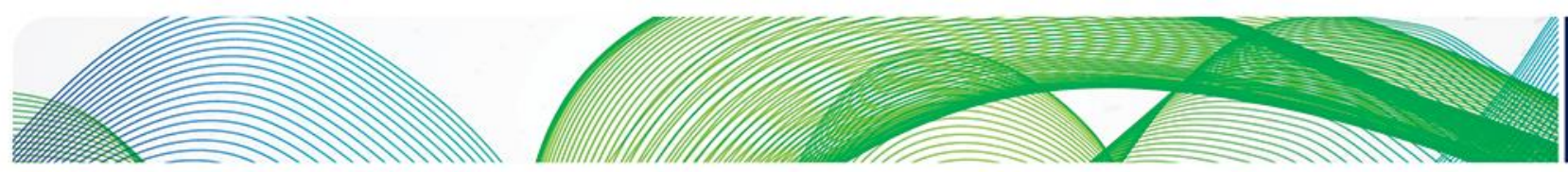

일

Figure 48: Merit order of Tanzanian installed capacity (Data source: AF-Mercados, 2013, all historical EPPs are included)
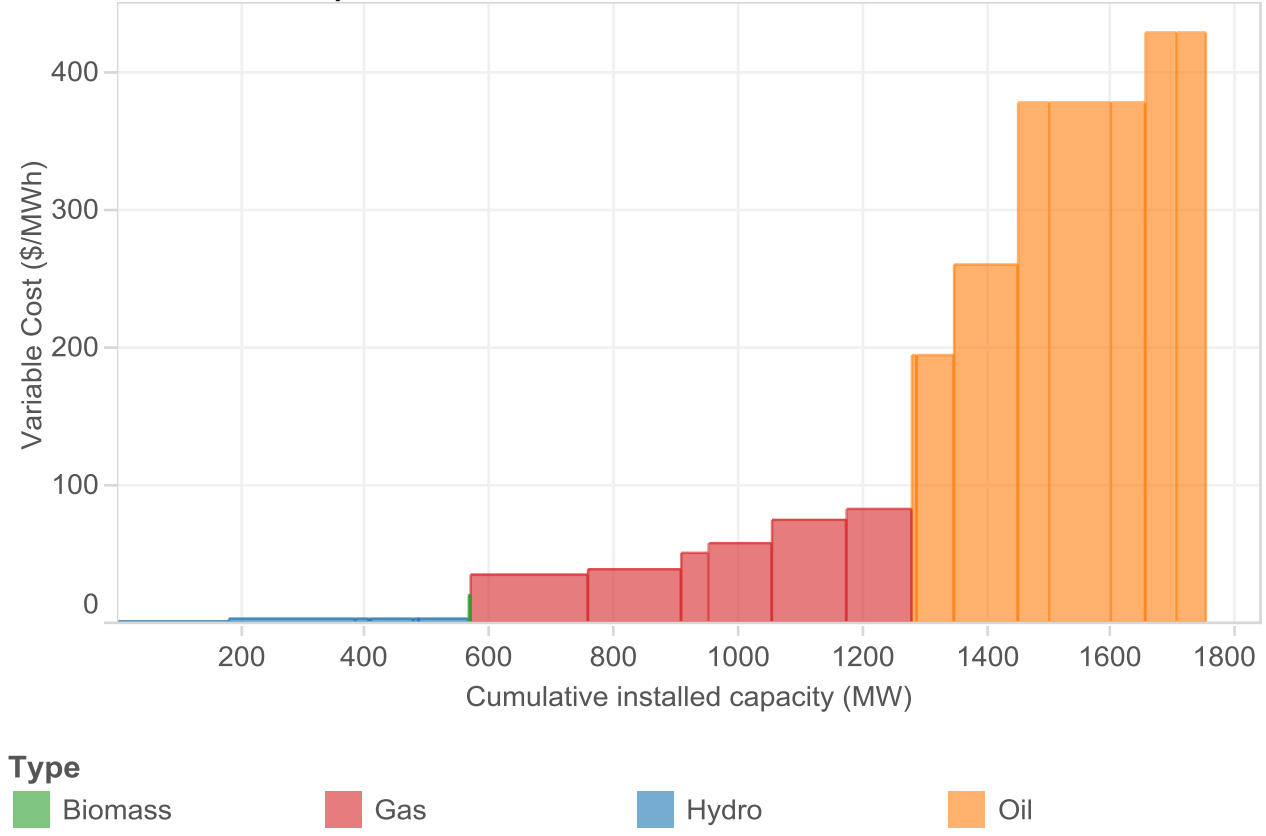

Does the tariff charged incentivize consumers to use electricity efficiently?

Within the approved tariff design, the capacity charge incentivizes T2 and T3 customers to increase their load factor (in other words, use contracted capacity more evenly and contract only as much as needed). The increasing block design for the energy charge of D1 incentivizes customers in this category with monthly consumption higher than $400 \mathrm{kWh}$ to switch to T1. All users consuming more than $200 \mathrm{kWh}$ are incentivized to contract power at the highest voltage level possible, given the lower average cost of electricity charged.

Given the Tanzanian power system's high sensitivity to peak demand (see the question above), it should be investigated whether additional measures such as time-of-use tariff could bring important system savings by avoiding the use of expensive oil-fired generation units (EPPs). In the long term, EWURA might consider transitioning from the accounting approach of cost allocation to the marginal cost approach, so that the use of electricity by Tanzanian ratepayers is based on the knowledge of the amount of future resources used to provide it.

\section{Economic sufficiency}

Are the allowed revenues to be recovered sufficient to cover the operating expenditures of the licensees, including a reasonable rate of return for the capital invested? Does the totality of tariff charged correspond to the allowed revenues (additivity)?

Because EWURA published the approved tariff levels but not the approved revenue requirement from which they were derived, it is not possible to ascertain the regulator's position toward specific items in TANESCO's proposed revenue requirement. 

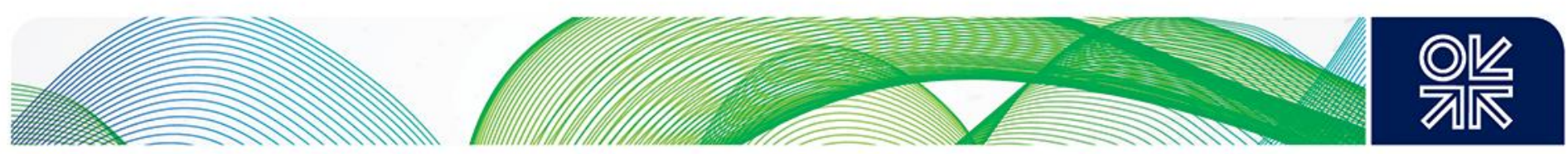

The tariff levels proposed by TANESCO for year $t$ is additive and sufficient to recover all revenue requirement (including operating expenses, loan repayment, and self-funded investment) proposed for the year $t-1$. The tariff approved by EWURA for year $t$ is just sufficient to recover operating expenses forecasted for the year $\mathrm{t}-1$. This is consistent with the trend exhibited by TANESCO's overall expenses and tariff-based revenue during 2006-10. Comparison of TANESCO's revenue requirement with the AF-Mercados CoSS shows that the amount of transmission and distribution network investment planned by TANESCO is significantly lower than what is expected. Possibly, part of that investment is shouldered by REA which is funding much of the distribution network expansion in rural areas. However, it could also be a sign that the (historical and expected) approved revenue requirement is not high enough to sustain TANESCO's own investments.

\section{Equity}

How are grants from the government and development partners treated in the computation of the revenue requirement?

When calculating its revenue requirement, TANESCO deducts its other sources of revenue, including government revenue grants, from the revenue requirement. This is consistent with the legislated principle that the costs covered by such revenue shall not be reflected in the revenue requirement. The EWURA-approved revenue requirement formula should be adjusted to incorporate such revenues.

Are there cases when customer classes are charged more than the costs they impose upon TANESCO (cross-subsidization)? How are such cases justified?

The extent of cross-subsidization in the case of the lifeline rate is limited. D1 customers who benefit from the subsidized lifeline rate consume 2.3 per cent of all energy supplied. They are responsible for 0.9 per cent of customer bills. The overall effect of the lifeline subsidy is small, and it is not formally justified in TANESCO/EWURA's documents. Assuming costs are to be allocated based on contribution to total demand, then the latest approved tariffs might have attributed more costs to be borne by T1 customers and less to be borne by T3-MV customers. It is hypothesized that this might be a decision on the part of the regulator, after consultation with representatives of electricity consumers, to cross-subsidize the industrial customers (T3-MV class).

\section{Stability}

Is the approved tariff consistent over time?

The approved tariff has been steadily increasing (especially the energy component of the tariff) since 2006. EWURA has consistently approved tariffs which are lower than the ones that TANESCO has applied for, and the average increase has never been higher than 40 per cent. When distinguished by customer class, the energy charges of D1 $<50 / 75 \mathrm{kWh}$ customers and of T3-MV customers have been increasing more slowly than those of other classes of customers. This observation is consistent with the cross-subsidization of D1 lifeline customers and the hypothesized cross-subsidization of T3MV customers.

The approved adjustment mechanism of tariff for changes in fuel costs, foreign currency exchange rate, and inflation, meant to reflect changes in costs that are beyond the utility's control, is expected to increase the volatility of the approved tariff over time. However, its implementation is unlikely to be automatic in the near future. The regulator has shown that it assesses the likely impact of the tariff adjustment before approving/disapproving adjustment according to the formula. Effectively, they become more frequent tariff reviews with smaller scope (only a component of the tariff is reviewed). This will decrease the regulatory lag in Tanzania's tariff setting process and, in theory, decrease the 

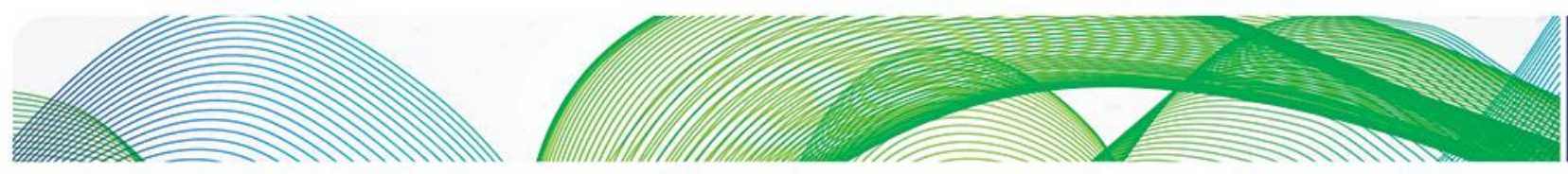

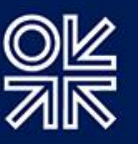

incentive for the regulated utility to seek efficiency savings. However, before a full oil-to-gas transition in the power sector is complete, fuel costs should be adjusted due to the fact that they are largely outside of the control of the utility (volatile oil prices and uncertain hydrology), so that not all risks are borne by the utility.

\section{International Experiences}

The experiences of Bangladesh and Côte d'Ivoire in the co-development of natural gas and electricity sectors can be used to shed light on the path forward for Tanzania. These countries were chosen based on the relative use of natural gas in power generation in their energy system and their level of electricity consumption. Based on 2012 data, Bangladesh, Côte d'Ivoire, Nigeria, and Bolivia, were the only lower-middle income countries with higher use of gas for power generation than that of Tanzania while exhibiting a per capita electricity consumption of less than 1,000 kWh (Figure 49).

Figure 49: Electricity consumption vs. electricity produced from natural gas for world countries (Data source: World Bank)

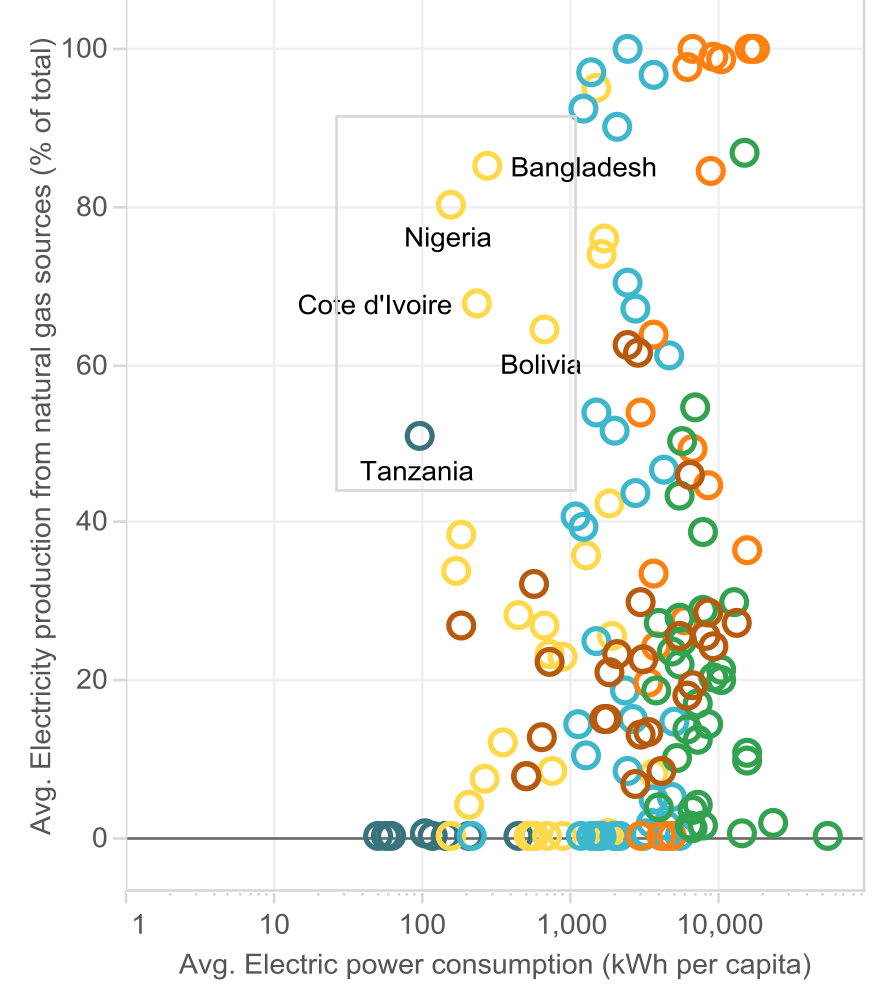

Upon further examination, Bolivia was seen as having significantly different starting condition: 67 per cent of its population had access to electricity in 1990, which is significantly higher the access rate for the three other countries (see Figure 50), therefore the screening continues with the first three countries. 

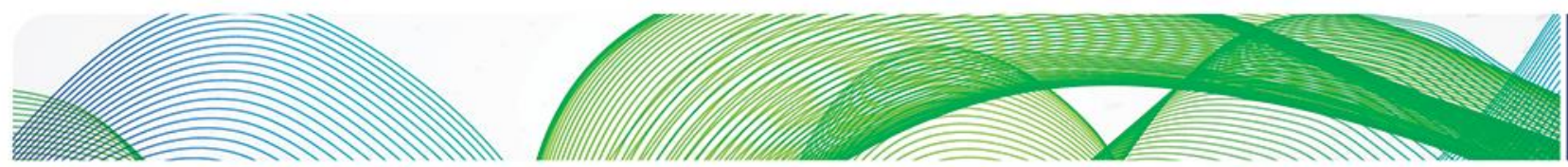

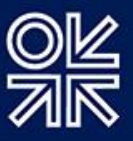

Figure 50: Development of electrification in select regions from 1990 to 2012 (Data source: World Bank)

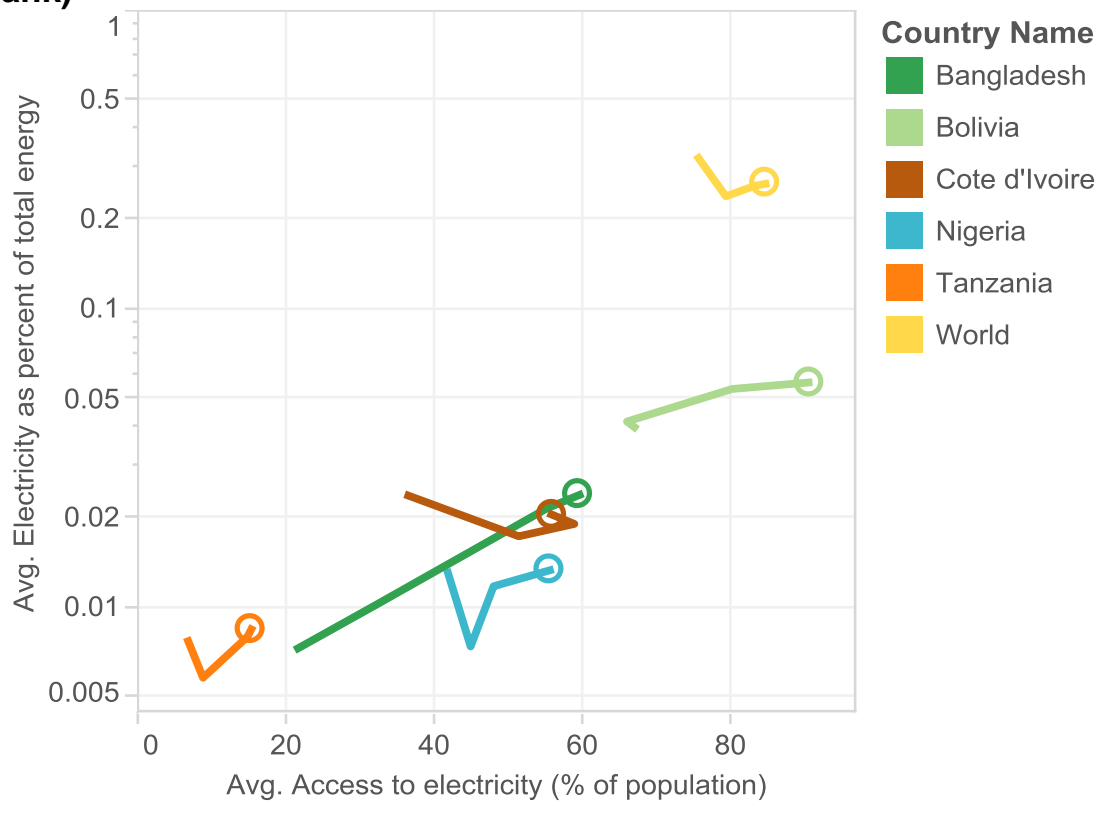

A quantitative analysis of the energy balance of the selected countries reveals that all four countries are completely self-sufficient in terms of natural gas, but only Nigeria has excess production (150 per cent of its consumption) which it exports (Table 9). The Nigerian energy system is also considerably larger than the other three (10 times larger), therefore it was not retained for a detailed country study. Bangladesh exhibits the most important dependence on gas, with 55 per cent of its total primary energy supply coming from natural gas; Nigeria and Côte d'Ivoire share similar gas dependence, while that of Tanzania is the lowest at 3 per cent. Bangladesh also ranks the highest among the comparison group for the percentage of total energy supply used for power generation and the relative importance of gas-to-power energy flow in the overall energy system. Bangladesh and Nigeria both have more diversified use for natural gas, as only about half of all natural gas is used for power generation. Relative to other comparison countries, Tanzania's generation mix has the lowest, but still significant, percentage of natural gas (56 per cent). 

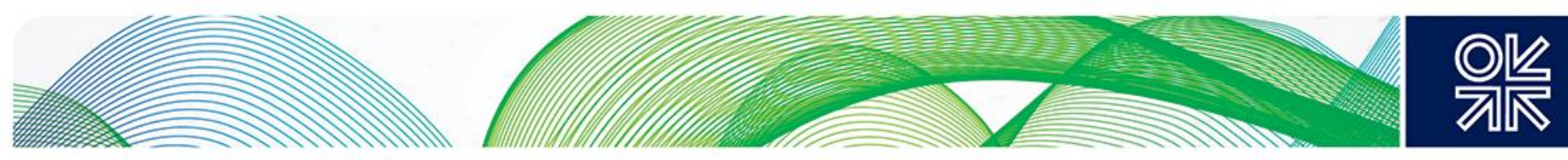

Table 9: Comparison of energy systems of Tanzania, Bangladesh, Nigeria, and Côte d'Ivoire (Data source: IEA for the year 2013)

\begin{tabular}{|c|c|c|c|c|c|}
\hline & Country & Tanzania & Bangladesh & Nigeria & Côte d'Ivoire \\
\hline \multirow{10}{*}{ 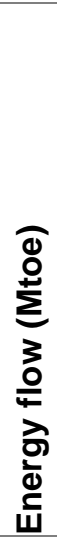 } & Production and imports (1) & 23.79 & 34.37 & 264.6 & 16.54 \\
\hline & Exports (2) & 0 & 0.11 & 131.4 & 3.46 \\
\hline & Total primary energy supply (3) & 23.79 & 34.26 & 133.2 & 13.08 \\
\hline & NG production (4) & 0.82 & 18.96 & 30.4 & 1.6 \\
\hline & NG consumption (5) & 0.82 & 18.96 & 12.2 & 1.6 \\
\hline & Power gen fuel cons. (6) & 1.22 & 12.54 & 5.6 & 1.8 \\
\hline & Power import (7) & 0.01 & 0 & 0 & 0.005 \\
\hline & Power consumption (8) & 0.38 & 4.56 & 2.5 & 0.65 \\
\hline & Power export (9) & 0 & 0 & 0 & 0.06 \\
\hline & NG for power generation (10) & 0.68 & 10.92 & 5.1 & 1.46 \\
\hline \multirow{8}{*}{$\begin{array}{l}\stackrel{0}{\stackrel{0}{\pi}} \\
\underset{\sim 0}{\simeq}\end{array}$} & \% NG sourced locally (4) / (5) & $100 \%$ & $100 \%$ & $249 \%$ & $100 \%$ \\
\hline & Gas dependence (5) / (3) & $3 \%$ & $55 \%$ & $9 \%$ & $12 \%$ \\
\hline & Energy used for power gen (6) / (3) & $5 \%$ & $37 \%$ & $4 \%$ & $14 \%$ \\
\hline & Power gen efficiency [(8) -(7)] / (6) & $30 \%$ & $36 \%$ & $45 \%$ & $36 \%$ \\
\hline & Power dependence (8) / (3) & $2 \%$ & $13 \%$ & $2 \%$ & $5 \%$ \\
\hline & $\%$ Gas used for power gen (10) / (5) & $83 \%$ & $58 \%$ & $42 \%$ & $91 \%$ \\
\hline & $\%$ Gas in power gen fuel $(10) /(6)$ & $56 \%$ & $87 \%$ & $91 \%$ & $81 \%$ \\
\hline & Relative NG for power gen (10) / (3) & $3 \%$ & $32 \%$ & $4 \%$ & $11 \%$ \\
\hline
\end{tabular}

\section{Bangladesh}

Bangladesh has significantly higher use of domestic natural gas compared to Tanzania. It also increased its installed generation capacity from 3,555 MW in 2000 to $11,877 \mathrm{MW}$ by 2015 (which is an equivalent of annualized growth of 8 per cent). However, it still experiences the same problem of energy demand growing rapidly to outstrip supply: in the country's Power Sector Master Plan of 2010, the addition of $30,000 \mathrm{MW}$ of capacity addition is planned by 2030 , which will require an estimated $\$ 59$ billion in investment (The World Bank, 2014).

\section{Power sector}

In 2000, IPPs owned about $320 \mathrm{MW}$ of available generation capacity, while the rest was provided by the Bangladesh Power Development Board (BPDB) (Murshid \& Wiig, 2001). Of the current total installed capacity, 6,365 MW is owned by public sector entities such as BPDB and its subsidiaries or joint ventures with the Rural Electrification Board (Ashuganj Power Station Company, Electricity Generation Company of Bangladesh, North West Power Generation Company, and Rural Power Company Ltd). A further $5,015 \mathrm{MW}$ is owned by private sector entities such as IPPs, Small Independent Power Producers (SIPPs), quick rental power plants (QRPP, the equivalent of EPPs in Tanzania), and long-term rental (BPDB, 2015b). This means that in the last 15 years, investment for 2,810 MW of generation capacity has been channelled through BPDB and its subsidiaries, while 4,695 MW of generation capacity has been channelled through vehicles that tap into private sector 

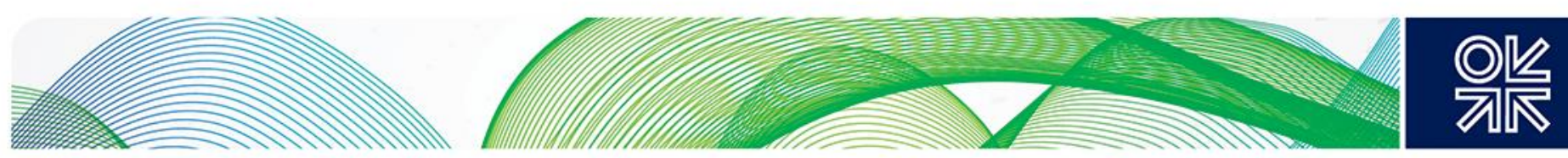

funds, such as IPPs, EPPs, and rental power. Breakdown of the generation capacity by ownership and by fuel is available for the year 2013: in that year, it can be seen that the non-public investment vehicle that contributed the most to installed capacity is rental power with contracts lasting from three to five years. Note that more than 60 per cent of the QRPPs are supplied by liquid fuel. These highcost temporary rental units were undertaken on a fast-track basis to address power shortage (Mujeri \& Chowdhury, 2013). The majority of all installed capacity (> 60 per cent) is made up by natural-gas fired generation capacity, given their dominance in the publicly owned generation and IPP portfolios.

Figure 51: Breakdown of generation capacity in Bangladesh (Data source: BPDB, 2014)

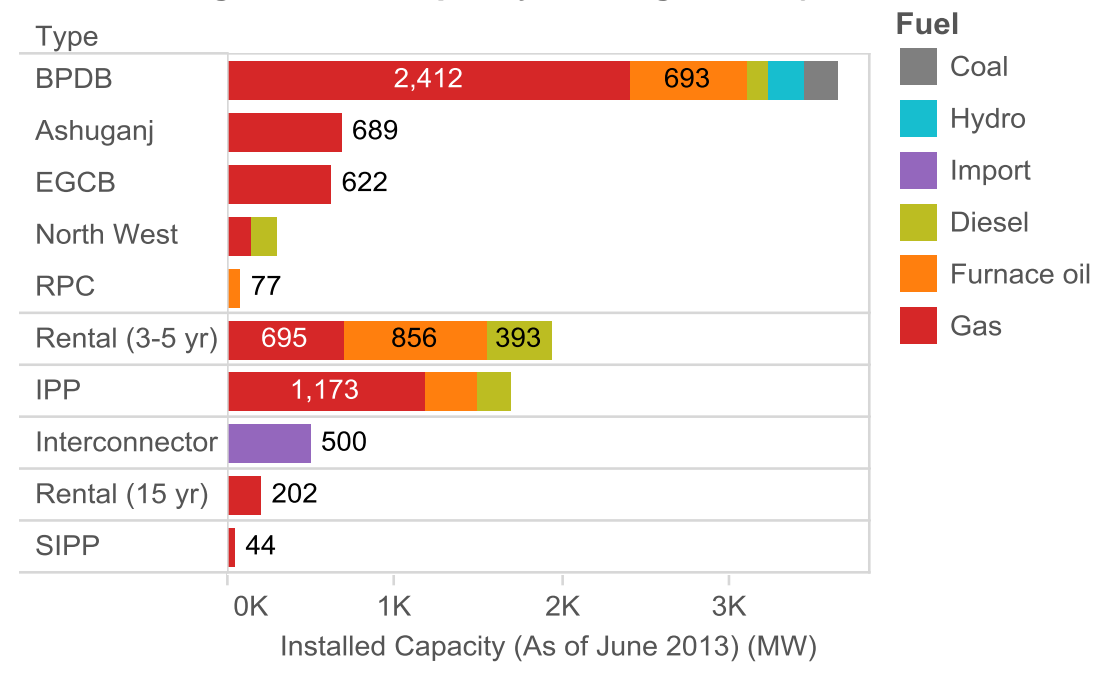

The structure of the Bangladesh power sector has undergone unbundling, but not full privatization. BPDB, the original vertically integrated public utility, was created in 1972. In 1977, the Rural Electrification Board (REB), a semi-autonomous government agency, was established to assist setting up Rural Electric Societies, also known as Palli Bidyut Samity (PBS), which own, operate, and manage distribution systems within their areas of jurisdiction. There are now 76 operating PBSs, covering more than 90 per cent of the area for rural electrification (REB, 2015). Partial transmission, distribution network development, customer service and, since 1991, to lessen the administrative burden on BPDB ${ }^{26}$. Responsibility over parts of the Metropolitan area was transferred to Dhaka Electric Supply Company (DESCO) in 1998 and DESA was later corporatized and became the Dhaka Power Distribution Company Ltd. (DPDC) in 2008. In 2002, further geographic disaggregation occurred with the creation of the West Zone Power Distribution Company Ltd. to improve accountability in electricity delivery and reduce distribution system loss.

The unbundling between generation and transmission occurred between 1996 and 2003, when the Power Grid Company of Bangladesh (PGCB) was created to own, operate, and expand the transmission grid (IAEA, 2013). The PGCB has regulated monopoly over the transmission network.

In 1996, BPDB was made into a holding company, and operational control over generation was decentralized into a number of independently managed entities. Ashuganj Power Company was created to take over the power station at Ashuganj, and the Meghnaghat Power Company (later

\footnotetext{
${ }^{26}$ Revenue collection in the Greater Dhaka Area was served by a separate entity, the Dhaka Electric Supply Authority DESA.
} 

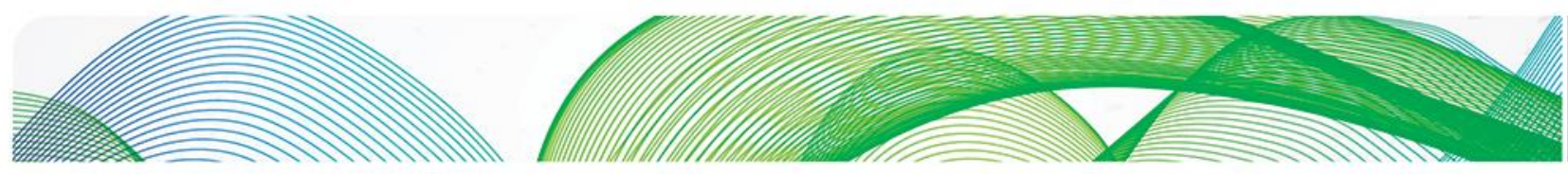

애잔

Electricity Generation Company of Bangladesh, EGCB) and North West Power Generation Company were established to implement generation plants financed by development partners (IMF, 2013). Rural Power Company (RPC), the first non-BPDB entity licenced to take up power generation, did so in 1994. Its entire equity investment has been mobilized domestically, with the REB owning 20 per cent share and the remaining 80 per cent owned by nine PBSs.

Despite the horizontal and vertical unbundling, BPDB still acts as the single buyer which purchases electricity generated by its public subsidiaries and private IPPs, SIPPs, and QRPPs at bulk power tariff rates, which are negotiated as part of the PPAs signed between them. For the year 2013-14, the average cost of electricity generated from all sources (BPDB and other public entities, IPP, rental power, and import from India), after removing additional costs such as interests on budgetary support and provision for maintenance and development fund from total costs, was Tk5.9/kWh $(\$ 0.076 / \mathrm{kWh})$ (BPDB, 2014) ${ }^{27}$.

Having acted as the single buyer, BPDB then sells electricity to distribution utilities, some of which are its subsidiaries, at wholesale tariffs regulated by the Bangladesh Energy Regulatory Commission (BERC). Distribution utilities then supply electricity to end-users at a retail tariff, also regulated by BERC. The categories of wholesale and retail tariffs are shown in Table 10. Categories G-1 and I-1 through I-4 are wholesale tariffs, while the remaining are retail tariff categories. In 2013-14, a total of 29.6 TWh of electricity was sold by BPDB to distribution utilities, and Tk135.3 billion was billed; this means an average wholesale tariff of Tk4.6 $/ \mathrm{kWh}(\$ 0.059 / \mathrm{kWh})$, which only recovers 78 per cent of the BPDB's procurement costs, or 73 per cent of overall costs. The retail customers of BPDB were charged Tk42,749 million for 8,456 GWh delivered (distribution system loss was 12 per cent), which was the equivalent of $\mathrm{Tk} 5 / \mathrm{kWh}$, higher than wholesale tariff but still lower than the overall procurement costs. The implication of this is that BPDB's net operating income was a loss of $\$ 647$ million. The accumulated deficit in BPDB's balance sheet is $\$ 4.37$ billion $^{28}$, given a total asset of $\$ 6.13$ billion. The company's net cash flow is negative in the order of Tk45.4 billion (\$584 million), but receives Tk61 billion ( $\$ 782$ million) from the government as budgetary support. ${ }^{29}$

As for the cost recovery of distribution utilities, DESCO and DPDC are sampled. In 2013-14, DESCO paid Tk5.4/kWh to BPDB and another Tk0.23/kWh to PGCB, a wheeling charge to recover the costs for the transmission grid operator (DESCO, 2014). Meanwhile, its effective retail tariff charge (after accounting for distribution system loss) is Tk6/kWh. In the same year, DPDC paid BPDB Tk5.34/kWh and the wheeling charge to PGCB, also achieving an effective retail tariff charge of Tk6/kWh (DPDC, 2014). A survey of the financial statements of PGCB reveals that the revenue from wheeling charges and other operating incomes is enough to cover operating expenditure, depreciation, and financing costs. This means that the systemic difference between operating costs and income is contained within BPDB's books.

\footnotetext{
${ }^{27}$ The reference exchange rate used in this section is $1 \mathrm{USD}=78 \mathrm{Tk}$ (Bangladeshi taka).

${ }^{28}$ This is almost five times larger than the accumulated deficit in TANESCO's balance sheet.

${ }^{29}$ This is the equivalent of $0.5 \%$ of the country's GDP of Tk135,09 billion.
} 

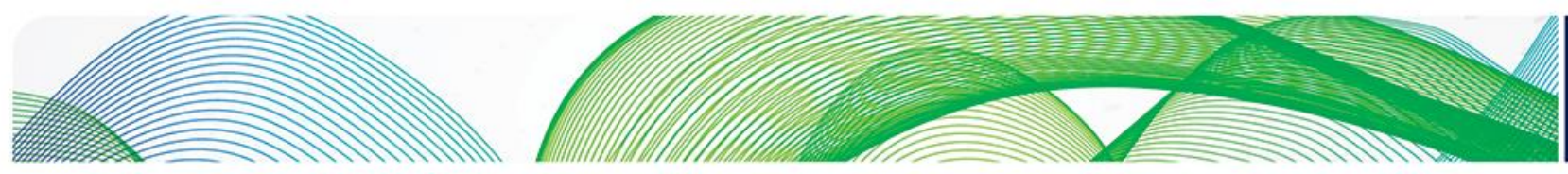

Table 10: Categories of BERC-regulated wholesale and retail tariffs (Data source: BPDB, 2015a)

\begin{tabular}{|c|c|c|}
\hline Category & Use & $\begin{array}{l}\text { Capacity } \\
\text { limit }\end{array}$ \\
\hline $\begin{array}{l}\text { A. Residential light \& } \\
\text { power }\end{array}$ & Charged for single meter in a dwelling place & $50 \mathrm{~kW}$ \\
\hline B. Agricultural pumping & $\begin{array}{l}\text { Charged for single meter for irrigation and land } \\
\text { drainage }\end{array}$ & $50 \mathrm{~kW}$ \\
\hline C. Small industrial & $\begin{array}{l}\text { Charged for single meter for small scale } \\
\text { production }\end{array}$ & $50 \mathrm{~kW}$ \\
\hline $\begin{array}{l}\text { D. Non-residential light } \\
\& \text { power }\end{array}$ & Charged for single meter in public establishments & $50 \mathrm{~kW}$ \\
\hline E. Commercial & $\begin{array}{l}\text { Charged for single meter for offices and } \\
\text { businesses }\end{array}$ & $50 \mathrm{~kW}$ \\
\hline $\begin{array}{l}\text { F. Medium voltage } \\
\text { general purpose }\end{array}$ & Charged at consumer sub-station & $5 \mathrm{MW}$ \\
\hline $\begin{array}{l}\text { G. Extra high voltage } \\
\text { - 1) DESA } \\
\text { - 2) General }\end{array}$ & $\begin{array}{l}\text { 1) Charged to DPDCL (successor of DESA) } \\
\text { 2) All consumer receiving at } 132 \mathrm{kV}\end{array}$ & $\begin{array}{l}15 \text { to } 150 \\
M W\end{array}$ \\
\hline $\begin{array}{l}\text { H. High voltage general } \\
\text { purpose }\end{array}$ & $\begin{array}{l}\text { All non-PBS consumers receiving at } 33 \mathrm{kV} \text { at own } \\
\text { sub-station }\end{array}$ & $15 \mathrm{MW}$ \\
\hline $\begin{array}{l}\text { I. High voltage bulk } \\
\text { supply for } \\
\text { 1) PBS } \\
\text { 2) DESCO } \\
\text { 3) West Zone } \\
\text { 4) BPDB }\end{array}$ & $\begin{array}{l}\text { PBS consumers receiving at } 33 \mathrm{kV} \text { at own sub- } \\
\text { station }\end{array}$ & $15 \mathrm{MW}$ \\
\hline $\begin{array}{l}\text { J. Street light and water } \\
\text { pumps }\end{array}$ & $\begin{array}{l}\text { Charged for a single meter for street lighting and } \\
\text { drinking water pumping stations }\end{array}$ & $50 \mathrm{~kW}$ \\
\hline
\end{tabular}

In the Bangladeshi power sector, the prevailing dynamic is one of demand growth continually outstripping the ability to provide stable supply (Figure 52). Although installed capacity caught up with peak demand in 2010, peak generation falls under peak demand, constrained by fuel shortage and generator outages due to lack of maintenance. Transmission and distribution losses, estimated to be 14 per cent in total, further detract from the supply of electricity available to meet demand. 

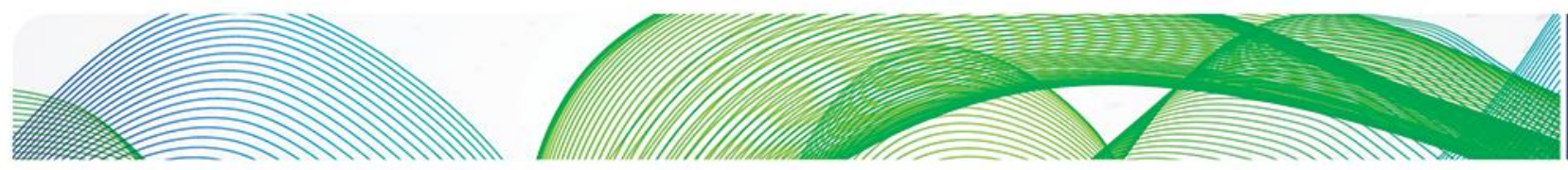

O는

Figure 52: Evolution of installed capacity, demand, and peak generation in Bangladesh (Data source: BPDB)
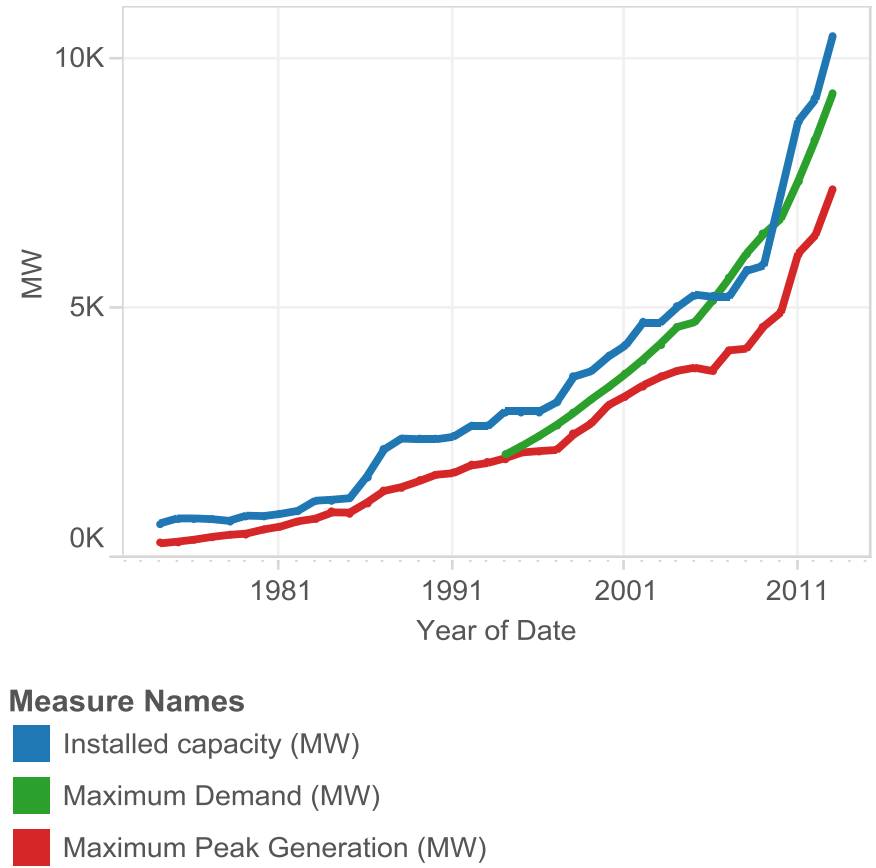

There are several factors that drive demand in electricity. Given that Bangladesh has not yet reached universal access to electricity, a significant number of new customers is added each year to the grid. From 2012 to 2013, the number of connected consumers on BPDB's distribution boards grew by 9.3 per cent. This is effectively the most important contribution to demand. The demand per connected consumer is also growing, because the current level is still below the world average. However, the growth is less significant: in 2012 the average electricity consumption per connected end-user of BPDB was 2,899 kWh, and this grew by 0.5 per cent in 2013 to reach $2,915 \mathrm{kWh} .{ }^{30}$ Finally, the population of the country is also growing at 1.4 per cent per year.

Since access to and consumption of electricity is perceived positively, their measures are used as government policy goals. Rather than actively managing demand, the current structure leaves the supply side to catch up with demand and fill the gap between them. In the short term, the increase of electricity generated is limited by the shortage of natural gas and the net capacity available, while it also simultaneously undermined by absolute distribution losses which grow with electricity transmitted over the network. In the long term, the increase of generation capacity is limited by the failure to maintain existing capacity, construction time, technical expertise, and financing required.

The main solution adopted by BPDB, the central actor within the power sector, has been to shorten construction time and avoid fuel shortages by installing liquid fuel-fired capacity that can be quickly procured. The financing constraint is addressed by signing PPAs with generator rental companies

\footnotetext{
${ }^{30}$ The average consumption per connected customer is significantly higher than the per capita consumption of electricity, because a large percentage of the population are not connected to the grid. Demand per consumer will be more accurate with disaggregated data that distinguishes between end-users of different types.
} 

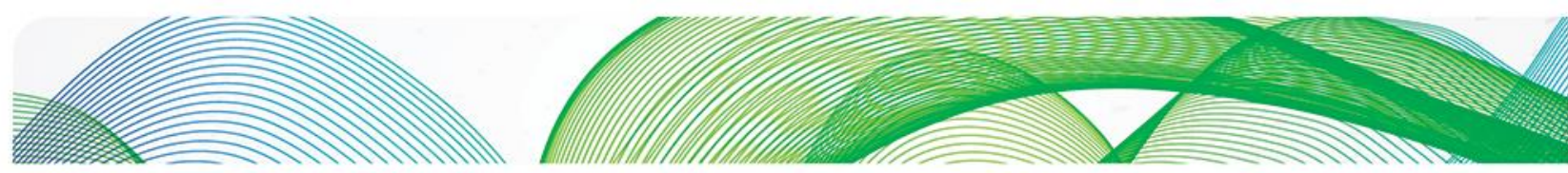

O는

which provide the investment required for obtaining and installing the generation units. The contracted companies are compensated in the future via capacity charges and pass-through of their fuel charges. The average cost of rental power paid by BPDB in 2013 was Tk10.12/kWh, or $\$ 0.13 / \mathrm{kWh}$, almost 70 per cent higher than the effective retail tariff charged to end-users, and 120 per cent higher than the average wholesale tariff charged to distribution utilities.

It was hoped that the emergency would be temporarily relieved by rental power, while larger-scale projects are planned concurrently to expand generation capacity. However, it was found that the implementation of the Power System Master Plan was taking longer than anticipated, and 'some flaws seem to have cropped in' that led to allegations of improper power plant investor behaviour (Mujeri \& Chowdhury, 2013, p. 34). The single buyer has high spending needs (the need to pay for liquid fuel and high capacity charges), while revenue recovered through wholesale tariffs is not enough to cover these costs. This leads to high accumulated losses in BPDB's books. Therefore, day-to-day operation of BPDB is sustained by injection of government support. Transmission and distribution utilities, which are the vehicles through which network expansion investment are made, have healthy financial positions because the margin between the regulated retail tariff and the regulated wholesale tariff is able to sustain their operations. Although contained within BPDB, the intervention by the state is in no way small - measuring 0.5 per cent of national GDP.

\section{Gas sector}

The shortage of gas, one of the most serious constraints limiting power generation using existing capacity with affordable fuels, has its root cause in the development of the Bangladeshi gas sector. The first oil and gas exploratory activity took place during the $1890 \mathrm{~s}$, but commercial production of natural gas in Bangladesh only began in 1960, due to disruption by the Second World War and the Independence movement in India. Of 23 discovered gas fields, 17 are currently in production. It was estimated that 10.8 Tcf of 20.6 Tcf recoverable natural gas reserve remained by June 2011. Daily gas production capacity in 2014 was 2,200 MMcfd, which could be sustained by the existing recoverable reserve figure for 13.4 years if it were to stay at the same level. 

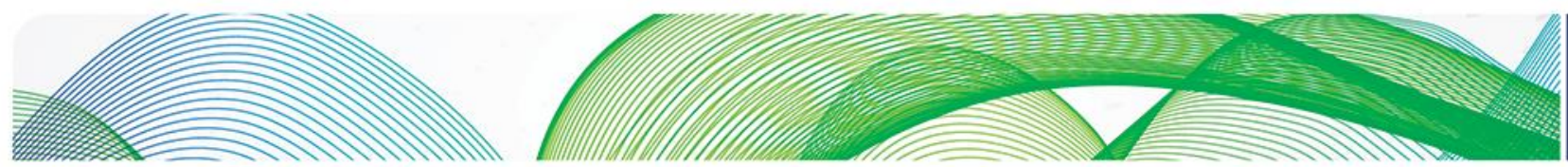

애존

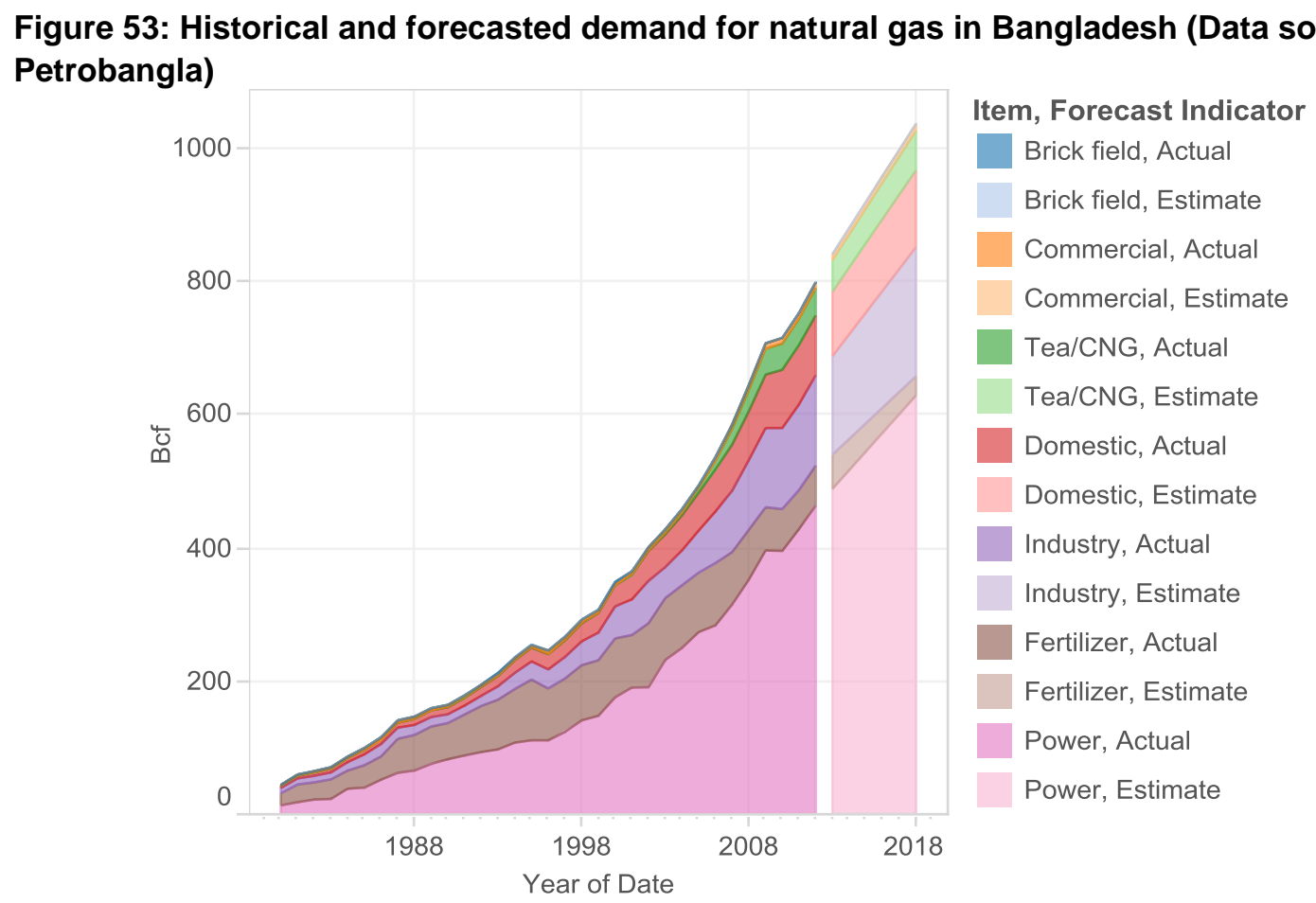

As early as 1980,37 per cent of natural gas produced was used for power generation, which accounted for 59 per cent of all power generation. As shown in Table 9, 58 per cent of natural gas produced in Bangladesh was used for power generation in 2013. Of the remainder, 16.9 per cent was used in industrial production, 12.3 per cent was used by the residential sector, 7.5 per cent was used as non-energy feedstock such as in fertilizer production, and 5 per cent was used for road transport through compressed natural gas vehicles (one-third of all transport energy uses). Between 1990 and 2013 , the annual average growth rate of gas demand in different sectors was highest in compressed natural gas (including a rapid burst between 2002 and 2008), industry, and domestic sectors (Figure 54). 

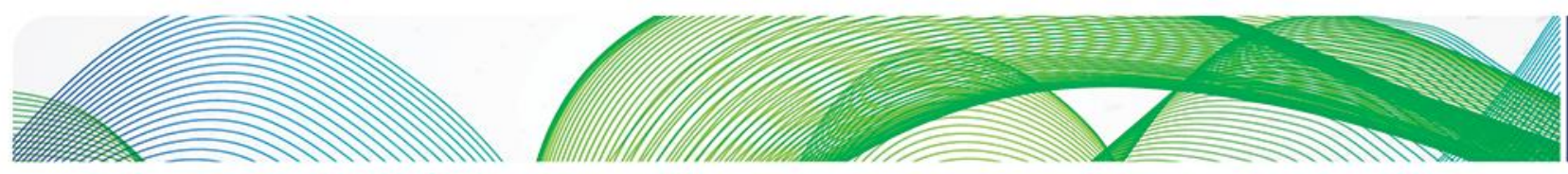

歌

Figure 54: Compound growth rate of gas demand in different sector since 1990 (Source: Petrobangla)

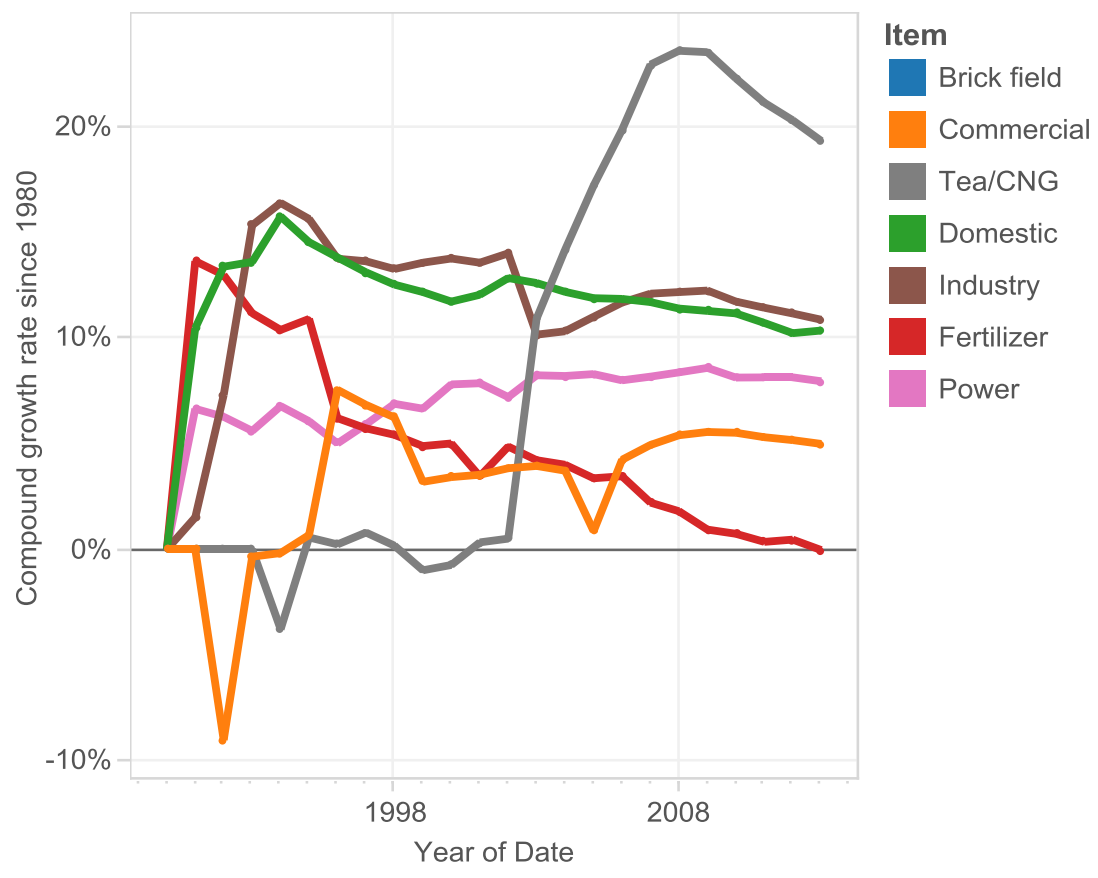

The Bangladesh Oil, Gas, and Mineral Corporation (Petrobangla) is the leading institution in the gas sector. It is responsible for all state-owned assets in the gas industry, with subsidiaries involved in all segments of the gas supply chain: exploration and production, production of compressed natural gas and liquefied petroleum gas, transmission, and distribution. At first, gas was only produced by state entities, and a uniform tariff that left minimal margins for gas sector entities was used. This arrangement discouraged private investment in the gas sector; consequently, the country decided to offer Production Sharing Contracts (same as PSAs) in 1996. According to Bangladesh's model PSC, the contractor recovers all costs and expenses out of a maximum 55 per cent of all available gas production from the contract area, referred to as 'cost recovery gas'. Expenses incurred in commercial production, planned capital expenditure costs, and exploration costs are recovered at the agreed rate on a straight-line basis, once commercial production begins. This draws parallels with capacity charges in a PPA. The balance of gas remaining after cost recovery is referred to as 'profit gas', and this is to be allocated between Petrobangla and the contractor in proportions agreed upon in the PSC. Petrobangla was to act as the single buyer of all IOC gas production (their share of profit gas) at 75 per cent of the high-sulfur fuel oil Singapore FOB price, on a heating value parity basis for onshore production, with a premium for offshore production. Also, the government was advised by the Asian Development Bank (ADB) to increase the tariff of state-produced gas to be aligned with the higher IOC price. In 1997, a committee was convened to review the recommendation of consultants, but the gradual enhancement of the tariff over three years was never implemented in full.

Today, IOCs (Chevron and Tullow) account for 1,425 MMcf, or 57 per cent, of total daily production (2,502 MMcf). In 2013, Petrobangla paid Tk61,354 million and obtained 438.7 Bcf of gas from the IOCs (this includes the share of profit case allocated to Petrobangla and the gas it purchased from 

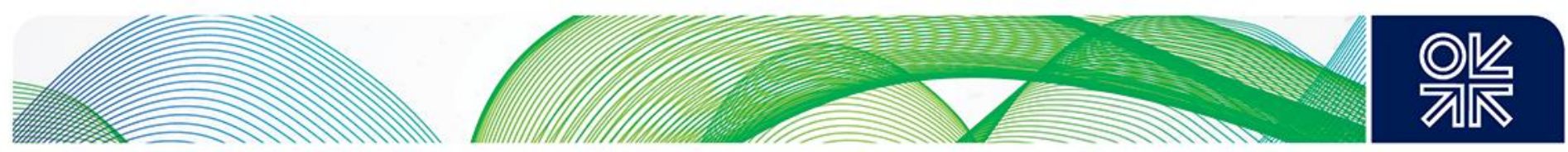

IOCs), which, assuming a heating value of $1,000 \mathrm{MMbtu} / \mathrm{MMcf}$, amounts to Tk140/MMBtu or \$1.8/MMBtu. For its own production (381.4 Bcf), the cost of sales was Tk81,718 million, which works out at Tk214/MMBtu or \$2.7/MMBtu. Combining all sources, the average cost of gas is $\$ 2.2 / \mathrm{MMBtu}$. On the other hand, Petrobangla's total gas sales for 2013 stood at $828.2 \mathrm{Bcf}$, for which it received Tk119,533 million, so the effective retail tariff was Tk144/MMBtu or $\$ 1.9 / \mathrm{MMBtu}$, which is the same as the average retail tariff provided by Titas in 2009 (Gomes, 2013). This means that the average gas tariff, like the power tariff, is not one that reflects the actual cost of sales. The current retail tariff structure of Bangladesh, like the one of power, differentiates between uses of gas. For the use of gas in the power sector, the tariff effective in 2013 was Tk79.82/MMBtu, or $\$ 1.02 / \mathrm{MMBtu}$. This is significantly lower than the production cost of gas (as determined based on the cost of sales from producers) and the price that gas fetches in other Asian countries (ADB, 2013). Overall, the low tariff of gas incentivizes a heavy economic dependence on natural gas and does not promote conservation.

As a result of below-cost gas tariffs, the power, industrial, and even transport sectors depend heavily on natural gas. Estimates from BP, Petrobangla, and the EIA indicate a growing supply-demand gap in the natural gas sector of Bangladesh. The ensuing narrative is one that mirrors the structure of that in the power sector: the possible growth in gas supply capacity is outstripped by the rapid growth in demand. On the supply side, there exist financial and technical constraints for the NOCs to develop offshore gas fields, and therefore they are almost completely dependent on IOCs to pursue offshore exploration. Given that the natural gas produced in Bangladesh is consumed domestically rather than exported, the terms of the PSC and the tariff at which IOCs can sell their profit gas will determine their interest in the country. Currently, commercial returns are not at a level that incentivizes IOC involvement. Furthermore, lack of addition/replenishment to supply capacity is not the only problem plaguing the gas sector. Also to blame are distribution losses and the use of gas in inefficient power generators, which can be partially attributed to a pricing of gas which does not reflect its just value.

\section{Learning point for Tanzania}

The case study of Bangladesh is a valuable one for Tanzania, given the many similarities in the recent development of their power sectors. Moreover, Bangladesh's power sector has developed to the stage which Tanzania aspires to reach in the future, namely: vertical unbundling between generation, transmission, and distribution; horizontal unbundling within generation and distribution; and the establishment of separate wholesale, transmission, and retail tariffs.

The case study reveals that the availability of a domestic fuel for power generation and a low tariff for its use in the power sector do not guarantee unconstrained growth of the power sector's ability to meet demand. Instead, the same problem encountered in the power sector - a demand that is growing at rate that cannot be sustained by local conditions - could be replicated in the gas sector. When the tariff of natural gas, a depletable resource that is extracted, is set to recover strictly necessary costs for extraction instead of the opportunity cost of its use, high and inefficient demand for gas is likely to develop in all sectors of the economy. This becomes problematic when the country in question does not have the developed technical and financial capacity to develop additional gas resources or alternative energy sources, bringing development to a halt. The case study also illustrates how the contracting of emergency power, perceived as a temporary solution, consumed project management capacity and cash flow from the public utility, potentially weakening the power sector's ability to develop more permanent forms of power generation capacity. Finally, decentralized rural electrification through PBS is very effective, but it also contributes to the rapid build-up of demand and stresses the fragile power system infrastructure. 

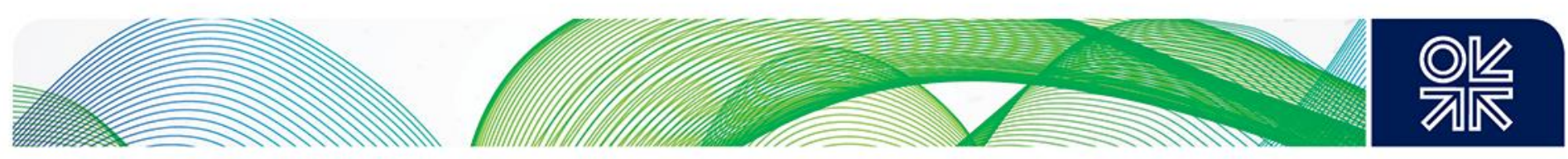

\section{Côte d'Ivoire}

For Côte d'Ivoire, the 2000 to 2010 decade was marked by a series of extremely disruptive events: a military coup overthrew the ruling president in 1999, an armed rebellion split the nation into the rebelheld north and the government-controlled south between 2002 and 2007, and violent events after the long-delayed 2010 presidential elections left 3,000 people dead and 500,00 displaced (BBC, 2016). Despite these socio-political challenges, the performance of Côte d'Ivoire's power sector relative to its neighbours has won it praise in the international press. The case study of Côte d'Ivoire is a story with unexpected turns: stagnant demand due to civil unrest and sluggish rural electrification was leveraged by the country to become a regional powerhouse in electricity export. But, the limitation of its domestic natural gas production is gradually becoming a constraint for Côte d'Ivoire's power sector. Diversification in generation capacity is sought through the procurement of additional hydro generation capacity and diversification in gas supply through planned procurement of LNG from Nigeria.

\section{Power sector}

Like Tanzania, Côte d'Ivoire opened its power sector to private participation in the early 1990s. In 1990 , the Ivorian government signed a concession contract with a private company, the Compagnie Ivoirienne d'Electricité (CIE), granting it a concession covering the purchase, transmission, and distribution of electricity in exchange for a lease fee (Traoré, 2013). The 15-year contract was renewed in 2005 for another 15 years. Meanwhile, the state retained the ownership rights to the power sector infrastructure. Currently, the state-owned company Société des Énergies de Côte d'Ivoire (Cl-Energies) is responsible for managing the publicly owned assets. It is also responsible for planning investment in the sector and for allocating the tariff revenue that CIE collects to different stakeholders in the power sector. CIE, the private concessionary, has no contractual obligation to invest capital in the sector.

The state-owned generation capacity is a portfolio of predominantly hydro-based facilities, all commissioned before 1990. In 1995, the first IPP of Côte d'Ivoire - Compagnie Ivoirienne de Production d'Electricité (CIPREL) - commissioned its natural gas-fired generator of $99 \mathrm{MW}$, followed by a $111 \mathrm{MW}$ unit in 1997. CIPREL later expanded its capacity twice, to reach a total installed capacity of $543 \mathrm{MW}$ (IFC, 2013). The other IPP, Azito, commissioned its expansion generators in 2016, adding $139 \mathrm{MW}$ to $300 \mathrm{MW}$ of gas generators. Both companies have signed Build-Own-Operate-Transfer type contracts with the government, so their assets are to be transferred to the government at the end of their contracts (Malgas \& Gratwick, 2008). Since 2010, Aggreko has been actively generating power in the country with its rental gas power generators and its contract is now extended until early 2017 (Aggreko, 2015b). 

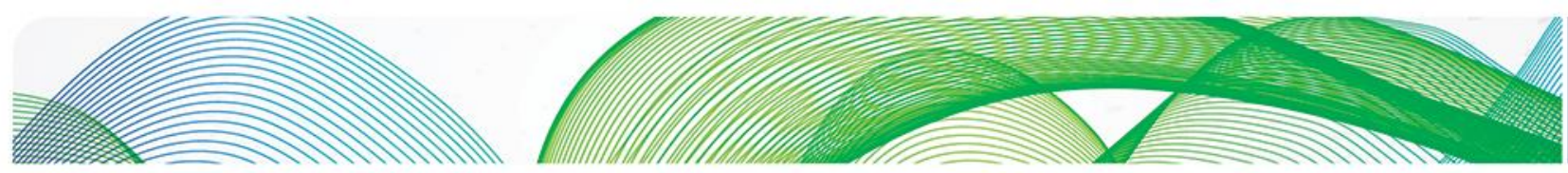

애잔

Figure 55: Breakdown of generation capacity in Côte d'Ivoire (Based on data from: Aggreko, 2015b; Globeleq, 2015; IFC, 2013; Malgas \& Gratwick, 2008)

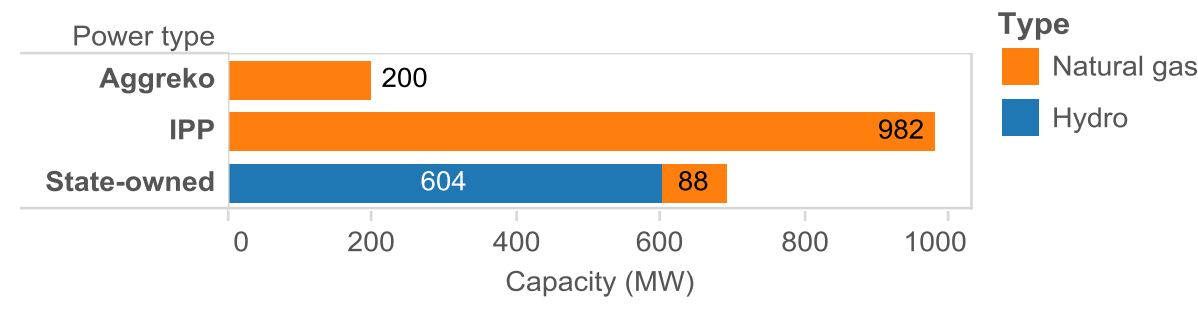

Extensive study of the development of IPPs in Côte d'Ivoire has revealed that there were project specific and country specific factors that have positively influenced the outcome of these projects (Malgas \& Gratwick, 2008). For the CIPREL project, the presence of favourable equity partners such as the Société d'Aménagement Urbain et Rural (SAUR), a company with two decades of experience operating in the country, and Electricité de France (EDF), a reputable public company, has facilitated the negotiation of the IPP. SAUR's parent company Bouygues, a French industrial group, also controls the CIE, the private company given concession over the ensemble of electricity sector activities, and Foxtrot, the most important gas producer in Côte d'Ivoire. Such pervasive presence of a single firm across all major functions of the supply chain may be unique, and it is believed that this provides the firm with influence over the operational risks, increasing its willingness to invest. Azito was procured at a time of abundance rather than scarcity (there was no impending shortage of electricity due to droughts, and the country's growth was positively perceived), therefore interest in the sector was at a level that warranted an international competitive tender, leading to the award of the contract to the lowest bidder. 

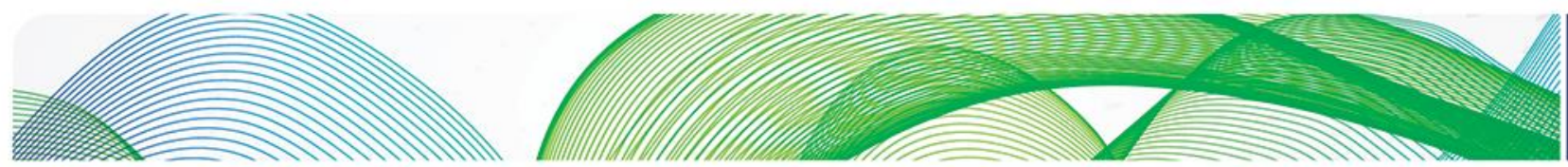

일

Figure 56: Electricity generation, consumption, and exports in Côte d'Ivoire between 1980 and 2012 (Data source: EIA)
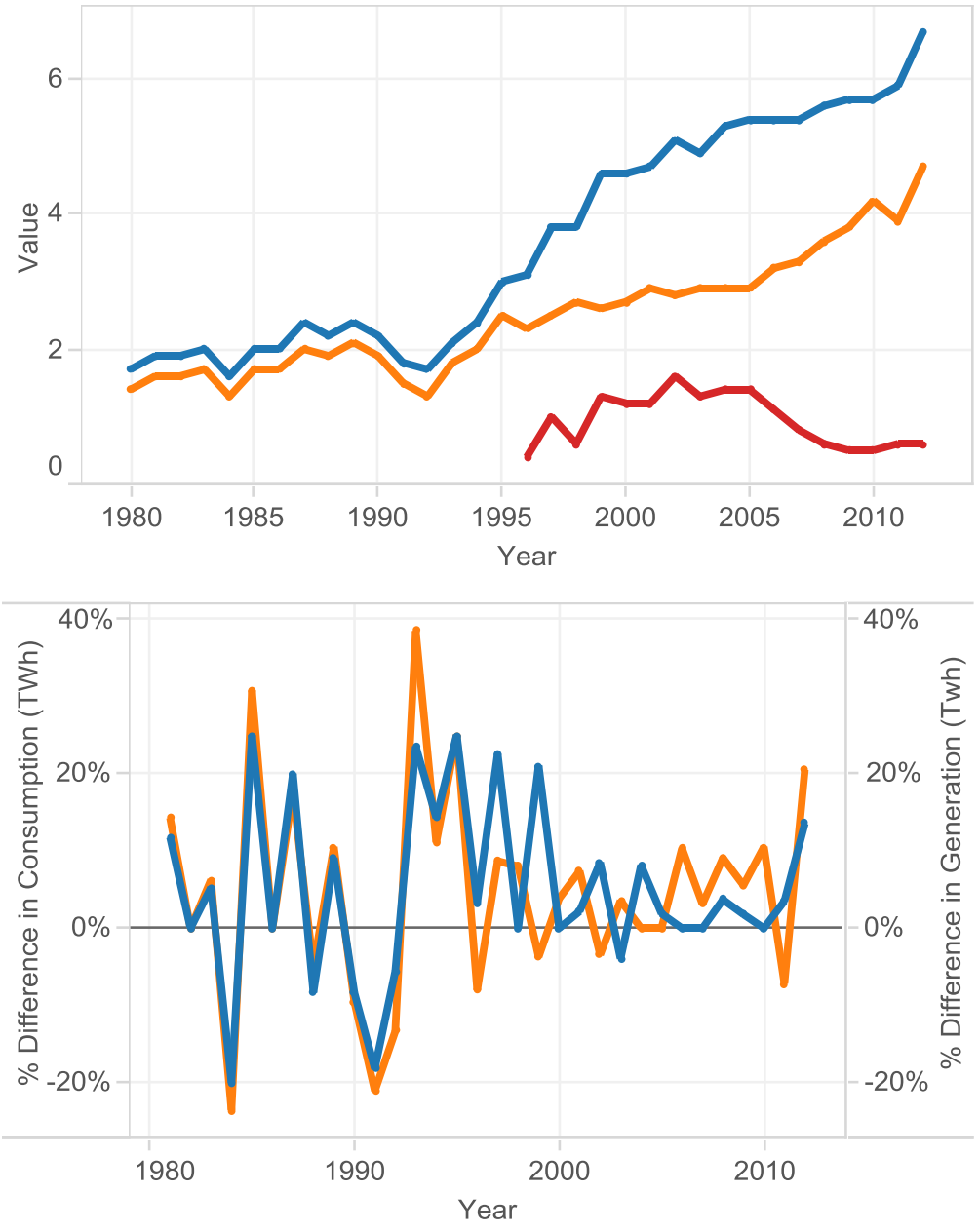

Measure Names

Consumption $\square$ Exports Generation

Between 1995 and 2005 electricity demand was stagnant, partly due to civil unrest in the 2000s (Figure 56). Côte d'Ivoire took advantage of its supply and demand mismatch to become the main electricity exporter in the region, given that it has established transmission links with Ghana, Togo, Benin, Mali, and Burkina Faso. CIE was able to maintain incoming revenues, bolstered by exports, even when revenues from serving domestic demand waned. The neighbouring countries were eager off-takers of electricity from Côte d'Ivoire, given their experiences of power deficit due to droughts and a general lack of power generation capacity. In 2002, the peak year for exports, 1,600 GWh or 31 per cent of total generation were exported.

Since 2005, the growth rate of consumption has been growing faster than that of supply (except for 2010-11, the year of post-election violence). At the same time, interconnections with Liberia, Sierra 

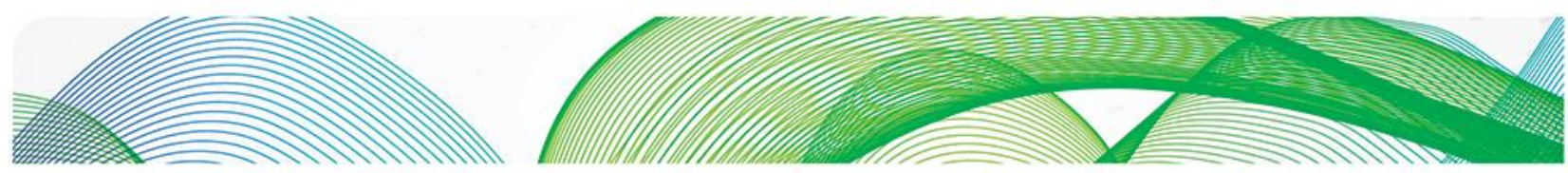

O는

Leone, and Guinea have been planned so that these countries can, in the short term, import electricity from Côte d'Ivoire, which has relatively more favourable conditions (Sieh, 2015). This means that the Ivoirian authority, still responsible for sector investment planning, needs to maintain supply growth in order to meet both domestic demand and export commitments. Given an existing installed capacity of 1,874 MW, Cl-Energies has set targets of reaching 3,290 MW by 2020 and 4,922 MW by 2030, through a mix of new privately funded thermal generation and publicly funded hydro generation capacity (Traoré, 2013). A $275 \mathrm{MW}$ hydropower plant owned by the government is currently under construction by Chinese state-owned Sinohydro, financed by a low-interest loan from the Chinese Exim bank of $\$ 500$ million (Reuters, 2013). Songon, a planned gas-fired project of $375 \mathrm{MW}$, is a good example of private sector initiatives. The gas-to-power project, developed by the domestic IPP Starenergie2073, will include the development of purpose-built LNG import infrastructure and a floating storage regasification unit (FSRU) (ESI Africa, 2015) .

The sector regulator Autorité Nationale de Régulation (ANARE) is responsible for proposing electricity tariffs to the State, but it does not have the right to set them. Between 2007 and 2012, the government increased tariffs by 10 per cent for three of the seven customer classes available. Nevertheless, the tariff hike did not increase at the same rate as the costs for power generation, leading to a structural deficit of funds in the sector. The increase in generation costs is due to increases in the cost of natural gas used, since the price of gas is indexed to West Texas Intermediate (WTI), a benchmark for oil pricing (ANARE, 2013). CI-Energies allocate the tariff revenues collected by CIE in a particular order: first, the management fees of CIE are paid; second, the IPPs and gas suppliers are paid; and finally, what funds are left are then allocated to major maintenance and refurbishment projects. The accumulated deficit is carried by the Government of Côte d'Ivoire, by renouncing the portion of gas sales to which it is entitled. It is also carried by IPPs and gas suppliers in the form of arrears, when governmental measures are insufficient to account for the deficit. Government subsidy to the sector in 2011 grew to 1.2 per cent of GDP, up from 0.4 per cent in 2009 (IMF, 2012).

In 2012, negotiations with gas producers led to a decrease in the price of gas from more than $\$ 9 / \mathrm{MMBtu}$ to $\$ 5.5 / \mathrm{MMBtu}$, which considerably lowered the revenue requirement for power generation (Figure 57). The reduction of commercial and technical losses, about 26 per cent in 2012, is also planned to bring the sector back to financial sustainability. Currency depreciation is not believed to be a factor in causing the deficit, since the CFA franc has been pegged to the Euro since 2002, and to the French franc 1994-2002, meaning that Côte d'Ivoire has not experienced currency devaluation as in the case of other African countries such as Egypt and Ghana (Malgas \& Gratwick, 2008). 

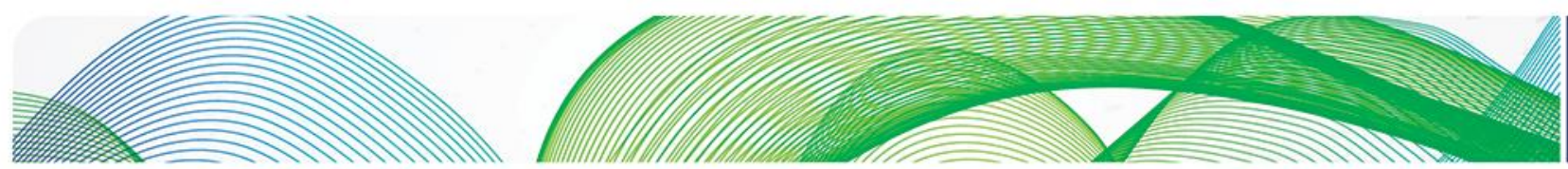

O는

Figure 57: Evolution of revenue requirement and tariff collected in Côte d'Ivoire (Based on data from: ANARE, 2013, 1 USD = 600 FCFA)

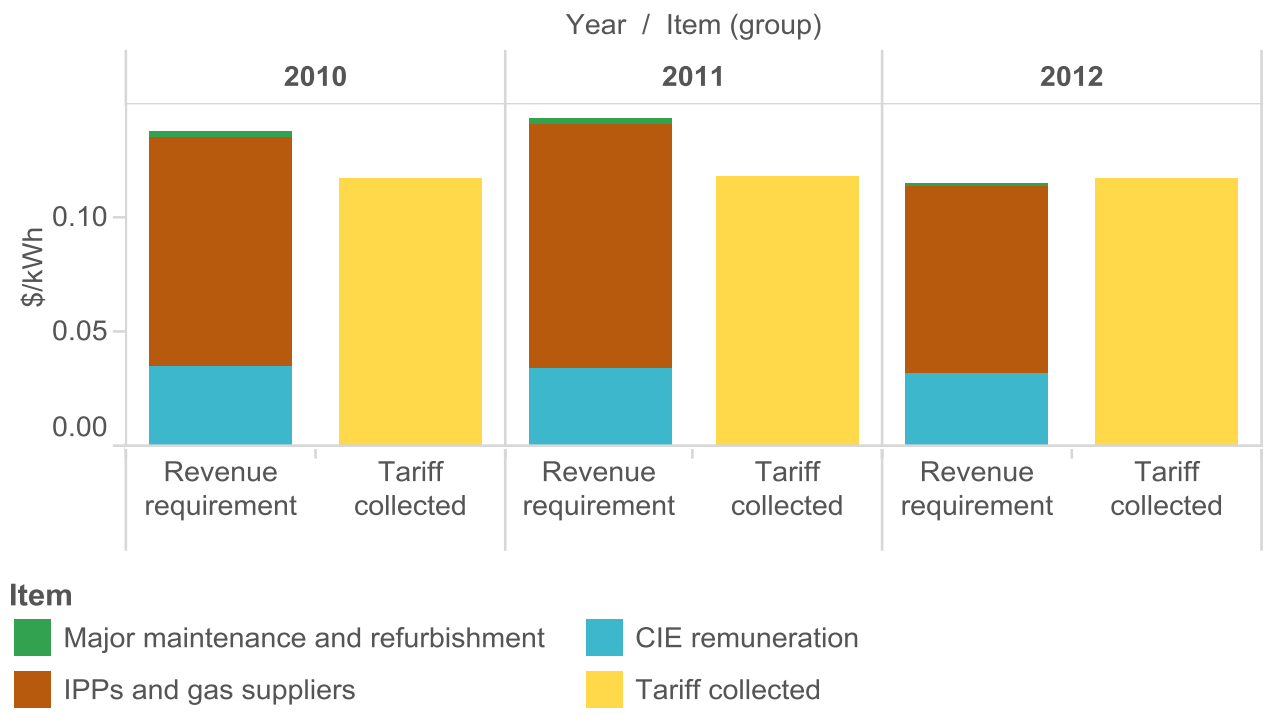

Figure 58: Evolution of rural electrification measures for Côte d'Ivoire (Base on data from: Ministry of Petroleum and Energy, 2012)

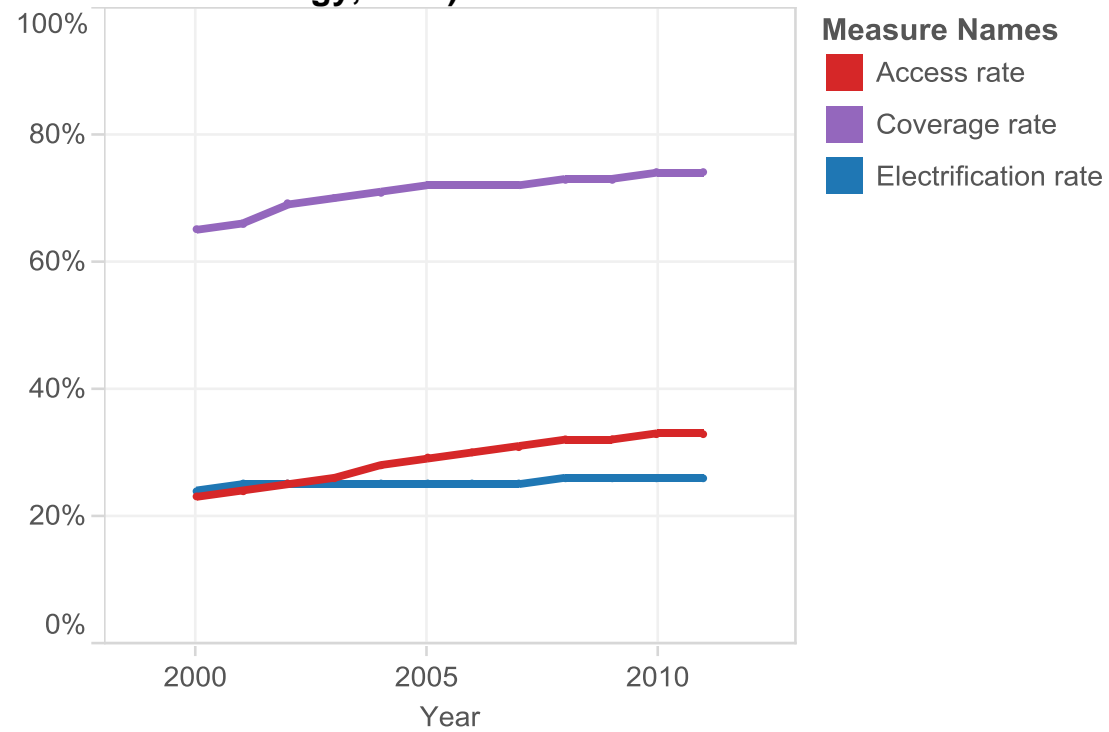

Several metrics exist to quantify the extent of electrification of Côte d'Ivoire (Figure 58). In 2012, the access rate (the percentage of population living in electrified areas) was 74 per cent, the coverage rate (the number of population centres electrified over the total number of population centres) was 34 per cent, and the electrification rate (the number of households with electricity over the total number of households) was 25 per cent. The difference between the first and the third measures could be perceived as the 'under-grid' population: those who live in regions where electricity services are 

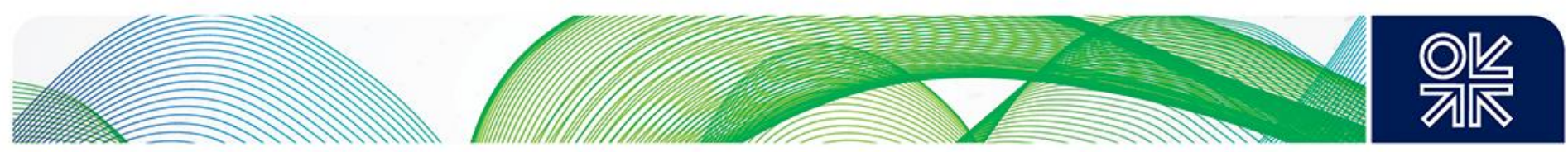

available but do not have access to them at home due to high costs. The figures suggest that this is a large proportion of the total population. Since 1990, the mandate of rural electrification was passed around multiple state-controlled institutions and has never been made a key priority. Between 1990 and 1998 it was the mandate of the monopoly Energie Electrique de Côte d'Ivoire (EECI), which lost the management rights of the electricity sector to CIE. After the dissolution of EECI in 1998, Société d'Opération Ivoirienne d'Electricité was made responsible for rural electrification, but it was also dissolved in 2011. Currently, the public sector company $\mathrm{Cl}$-Energies has responsibilities over rural electrification. In consequence, the electrification rate between 2000 and 2012 has remained static, while the cover rate and access rate have both improved marginally.

\section{Gas sector}

Like Tanzania, the use of natural gas in Côte d'Ivoire began with its IPPs. In late 1995, natural gas from Panthère field was delivered by pipeline to the commercial capital Abidjan, where the CIPREL generators are located. Companies there produce all of the natural gas used in Côte d'Ivoire: AFREN, $\mathrm{CNR}$, and Foxtrot, after signing PSAs with the national oil company, PETROCI. These independents (as opposed to IOCs) are also involved in the production of oil. By the end of December 2014, 232 MMcf of gas was produced per day (roughly 85 Bcf per year), of which 70 per cent was used for electricity production (Ministry of Petroleum and Energy, 2015). Natural gas uses in other sectors include the production of NGL and the heating of industrial processes. At this rate, the proven reserves of $1.1 \mathrm{Tcf}$ can only sustain existing power generation for 18 years. This is comparable to Tanzania's current reserve production ratio, if only the near-shore reserves are considered. Current production capacity is below the maximum needs for gas of the power sector by about $100 \mathrm{MMcf} /$ day. The shortage of gas, more pronounced during peak hours, has led several gas-fired generation stations with dual-fuel capability to occasionally use liquid fuel for power generation since 2006 (ANARE, 2013). Increasing mining activities could further increase the size of this gap (the mines have the option of directly procuring gas to run their own generators or to connect the mines to the existing power grid).

Although IPPs are the main off-taker of gas, the existing gas supply agreements are contracts signed by the government and the natural gas producers, therefore the Ivoirian government takes the lead in securing gas supplies for the power sector. A Technical Gas-Electricity Committee (headed by ANARE and including all gas producers, all IPPs, CIE, CI-Energies, PETROCl, and the two ministry directorates responsible for electricity and petroleum) meets bimonthly for mutual coordination and mediation. In case of extraordinary events, the committee is responsible for analyzing the incidents, determining the utilization of gas production, distribution, and consumption equipment in the short term, and nominating the quantity of gas supplied to the power sector, to PETROCI, and a refiner (the most important industrial customers). The most important gas producer, Foxtrot, is active in exploration, but these efforts are believe to be only enough to secure production for the next 10 years (Reuters, 2014). As for import options, the Ivorian government has started collaboration with Nigeria to receive LNG deliveries and, eventually, after the extension of the West African Gas Pipeline (WAGP), piped natural gas (Chinonso, 2015). Given the perceived unreliability of WAGP supply, it is believed Côte d'Ivoire will be dependent on the more secure LNG supplies. The current LNG supply glut in the global market means that the importers are likely to have more bargaining power in the negotiation of gas supply contracts, which is advantageous to Côte d'Ivoire's current position.

\section{Learning point for Tanzania}

In many ways, Côte d'Ivoire is very similar to Tanzania, especially in the development timeline of its power and gas sectors. However, the nature of private sector presence, the growth of power demand, and the natural gas endowment of the two nations are very different. 

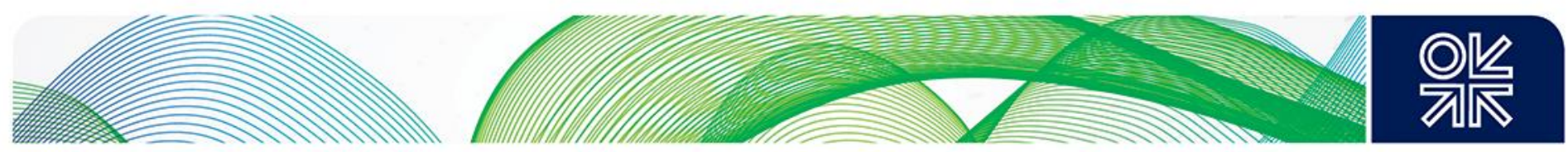

The companies controlled by Bouygues span gas production, power production, and power retail. Their influence has been considered mostly positive, given that this quasi-vertical integration lowers the companies' operational risks, which could increase the parent company's willingness to invest. The stagnant growth of power demand, partially attributed to civil unrest and to non-aggressive rural electrification efforts, has been transformed into a relative advantage for Côte d'Ivoire. The overcapacity available, procured on-time due to smooth IPP construction and commissioning, has been used for export to neighbouring countries, which bolstered Côte d'Ivoire's reputation as a regional powerhouse, further encouraging investment. As the country's power demand growth accelerates, it is in a relatively good position to attract private investment. The Ivoirian experience demonstrates the critical nature of timing; the pacing of supply growth relative to demand growth. Once supply (sourced at reasonable prices) is sufficient to cover existing demand with a comfortable margin, it becomes easier to procure future supply, changing the dynamics of power system planning from demand-pulled to supply-pushed. Although Côte d'Ivoire has significantly less natural gas than Tanzania, which might be unfavourable in the long term for its gas-to-power projects, the current global LNG market is more favourable to importers than exporters, given the glut of LNG export project commissioned/to be commissioned within a short period of time. While Tanzania's plans for off-shore natural gas development might be delayed, Côte d'Ivoire might be able to enjoy more competitive LNG imports than would otherwise be the case.

However, the Ivorian model also exhibits some major weaknesses. The lack of institutions dedicated to the cause of rural electrification is believed to be the cause of the stagnant electrification rate since 2000. Also, high technical and commercial losses ( 26 per cent) are experienced despite management of the whole sector by a single private company, since that company is not incentivized/allowed to invest in power sector infrastructure.

\section{Conclusion}

In order to fulfill its aspiration to become a middle-income country, Tanzania is working on improving infrastructure and service delivery in electricity provision, where $\$ 40$ billion investment is needed in the sector to meet rising demand and widening electrification efforts from 2013 to 2035. In order to understand whether these important investments can be secured in time, the institutional arrangements for investment in Tanzania's power sector have been presented. The track record in funnelling investment to the sector has been surveyed, and possible organizational bottlenecks discussed. The tariff setting methodology in place in Tanzania, as evidenced through its latest tariff review, has been studied in detail, and areas of improvement have been suggested. Finally, international experiences from Bangladesh and Côte d'Ivoire in co-development of their power and gas sectors were presented in order to provide insights to Tanzanian stakeholders.

Among the five investment vehicles available (TANESCO, IPPs, EPPs, SPPs, PPPs), investment through TANESCO has remained important throughout the development of the power sector, but it has rested upon the contribution from government and development partner grants, despite stated government interest in transitioning to a self-sustained market-led model. The financial health of TANESCO is central to all investment vehicles, since it is either directly responsible for investment, or indirectly, as the counter party to the variety of PPAs available with IPPs, EPPs, SPPs, or PPPs. During 2011-13, the financial position of TANESCO was negatively impacted by the increase in costs of its purchase electricity, while the regulated tariff that it charges has not changed. The increase in costs is partially attributable to non-favourable hydrology, partially attributable to the depreciation of the Tanzanian shilling against the US dollar, the currency in which PPAs are denominated. 

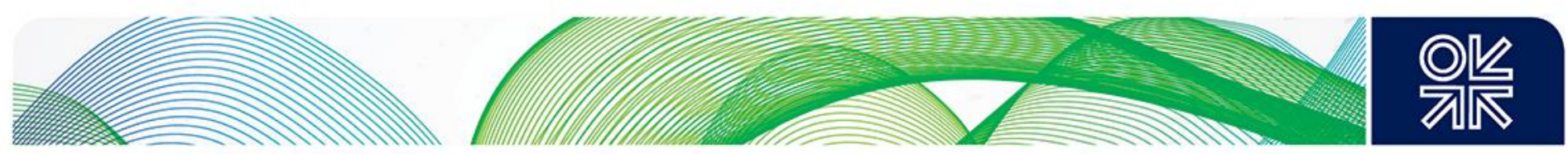

The experiences of channelling private equity and commercial loans via IPPs and EPPs have had mixed outcomes, where the lack of due diligence during procurement and the negotiation of the PPA often led to long and controversial legal disputes that incurred significant indirect costs, as well as blemished the public perception of private investment in Tanzania. The regulatory framework that Tanzania has set up for SPPs has attracted international accolades, but the limited equity of domestic investors has led to a correspondingly limited number of generation projects procured thus far. PPPs have not yet materialized, but they have the possibility of leveraging Tanzania's newly found gas reserves into strategic, collaborative investments with China and becoming the most important investment vehicle among the five. It has been highlighted that, even when the power sector investments are forthcoming, it should not be forgotten that timely investments in the gas sector are also required for the gas-to-power transition to be realized. In the short term, this requires TANESCO to improve its payment records for its existing gas supply contracts to encourage further development of near-shore reserves. In the long term, this requires the government to carefully monitor the effect of its PSA terms and the international gas market on its IOC partners' willingness to invest in off-shore production.

Upon review of Tanzania's power tariff setting mechanism, it has been found that the methodology used by the regulator reflects the rate-making principles upheld by the Tanzanian legislation in general. However, a core tension within Tanzania's tariff setting methodology is the trade-off between efficiency, sufficiency, and stability principles. The ex ante assessment of TANESCO's revenue requirement, a typical incentive-based price cap regulation, is theoretically efficient but not robust: TANESCO's costs of service are subject to important external uncertainties like hydrology, currency depreciation, and global fuel prices. In order to take revenue sufficiency into account, the regulator then needs to periodically adjust tariffs based on ex post fuel costs and inflation rates. This diminishes the regulator's ability to maintain tariff stability, which might impact certain classes of customers more than others (lifeline rate customers and domestic industries).

The Bangladeshi experience reveals that the availability of a domestic fuel for power generation and a low tariff for its use in the power sector is not enough to sustain unconstrained growth of electricity demand. Instead, the same problem encountered in the power sector - a demand that is growing at a rate that cannot be sustained by local conditions - could be replicated in the gas sector. Because natural gas is a depletable resource, the tariff for its consumption needs to be determined especially carefully, so that it does not incentivize its inefficient use throughout the economy or discourage investors with the technical and financial resources needed to continue the development of gas within the country. The case study of Côte d'Ivoire reveals that the pacing of supply growth relative to demand growth is of critical importance. Experiencing stagnant demand due to civil unrest and slow rural electrification, the surplus of generation capacity procured in the late 1990s was leveraged by Côte d'Ivoire, which became the most important regional electricity exporter. Expansion of generation capacity following that has been marked by a supply-pushed rather than demand-pulled dynamic, and investor interest has been abundant. Even then, the Ivoirian case has also shown that gas supply development (changes in gas price and bottlenecks in gas production) could jeopardize a power sector in relatively good health. 


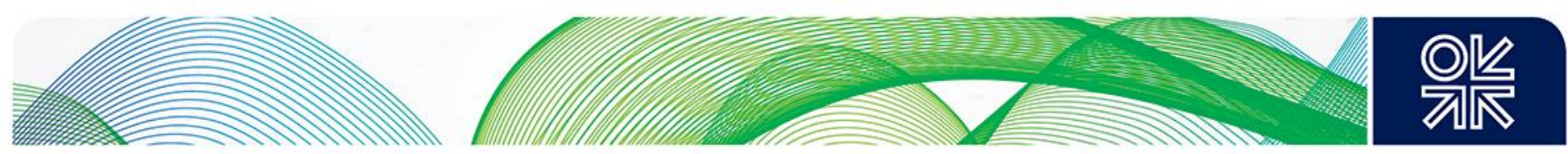

Appendix I: Data

Table 11: List of historical and planned generation capacity in Tanzania (Data source: (Greacen, 2014; Kihwele et al., 2012; Lazimah, 2014; Ministry of Energy and Minerals, 2013a; The United Republic of Tanzania Ministry of Finance, 2014; Tsakhara, 2015) )

\begin{tabular}{|c|c|c|c|c|c|c|c|}
\hline Power type & Name & Owner & Grid & Type & Capacity & Year commissioned & Year planned \\
\hline TANESCO & Hale & TANESCO & On-grid & Hydro & 21 & 1967 & \\
\hline TANESCO & Nyumba ya Mungu & TANESCO & On-grid & Hydro & 8 & 1968 & \\
\hline TANESCO & Kigoma & TANESCO & Off-grid & Oil & 12.5 & 1973 & \\
\hline TANESCO & Kidatu & TANESCO & On-grid & Hydro & 204 & 1975 & \\
\hline TANESCO & Liwale & TANESCO & Off-grid & Oil & 0.8 & 1975 & \\
\hline TANESCO & Mtera & TANESCO & On-grid & Hydro & 80 & 1979 & \\
\hline TANESCO & Bukoba & TANESCO & Off-grid & Oil & 2.4 & 1984 & \\
\hline TANESCO & Songea & TANESCO & Off-grid & Oil & 8.2 & 1987 & \\
\hline TANESCO & Uweba mini hydro & TANESCO & On-grid & Hydro & 0.843 & 1989 & \\
\hline TANESCO & Biharamulo & TANESCO & Off-grid & Oil & 1 & 1991 & \\
\hline TANESCO & Mafia & TANESCO & Off-grid & Oil & 0.9 & 1991 & \\
\hline TANESCO & Mpanda & TANESCO & Off-grid & Oil & 2.7 & 1991 & \\
\hline TANESCO & Ngara & TANESCO & Off-grid & Oil & 0.852 & 1991 & \\
\hline TANESCO & Tunduru & TANESCO & Off-grid & Oil & 1.98 & 1992 & \\
\hline TANESCO & New Pangani Falls & TANESCO & On-grid & Hydro & 68 & 1995 & \\
\hline TANESCO & Dodoma TANESCO & TANESCO & On-grid & Oil & 7.4 & 2000 & \\
\hline TANESCO & Kihansi & TANESCO & On-grid & Hydro & 180 & 2000 & \\
\hline IPP & Tegeta IPTL & IPTL & On-grid & Oil & 103 & 2002 & \\
\hline IPP & Songas & Songas & On-grid & Gas & 189 & 2004 & \\
\hline
\end{tabular}




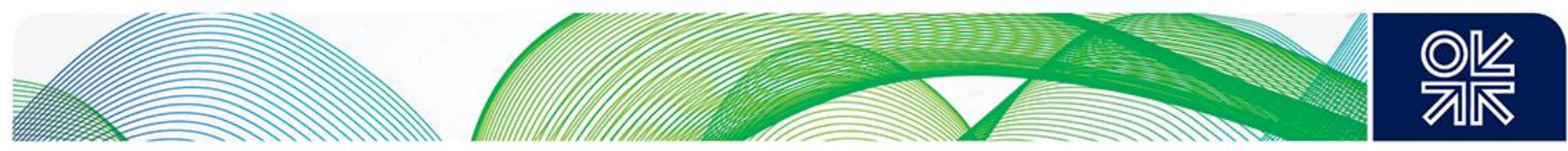

\begin{tabular}{|c|c|c|c|c|c|c|c|}
\hline TANESCO & Ubungo I & TANESCO & On-grid & Gas & 102 & 2007 & \\
\hline TANESCO & Ludewa & TANESCO & Off-grid & Oil & 1.27 & 2008 & \\
\hline TANESCO & Mbinga & TANESCO & Off-grid & Oil & 2 & 2008 & \\
\hline TANESCO & Tegeta TANESCO & TANESCO & On-grid & Gas & 44 & 2009 & \\
\hline SPP & TPC & TPC & On-grid & Biomass & 2.5 & 2010 & \\
\hline SPP & TWC & TANWAT & On-grid & Biomass & 1 & 2010 & \\
\hline TANESCO & Somanga Fungu & TANESCO & Off-grid & Gas & 7.5 & 2010 & \\
\hline EPP & Symbion & Symbion & On-grid & Gas & 120 & 2011 & \\
\hline EPP & Aggreko - Tegeta & Aggreko & Decommissioned & Oil & 50 & 2011 & \\
\hline EPP & Aggreko - Ubungo & Aggreko & Decommissioned & Oil & 50 & 2011 & \\
\hline TANESCO & Kasulu & TANESCO & Off-grid & Oil & 2.5 & 2011 & \\
\hline TANESCO & Kibondo & TANESCO & Off-grid & Oil & 2.5 & 2011 & \\
\hline TANESCO & Loliondo & TANESCO & Off-grid & Oil & 5 & 2011 & \\
\hline TANESCO & Sumbawanga & TANESCO & Off-grid & Oil & 5 & 2011 & \\
\hline EPP & Symbion - Arusha & Symbion & Decommissioned & Oil & 50 & 2012 & \\
\hline EPP & Symbion - Dodoma & Symbion & Decommissioned & Oil & 55 & 2012 & \\
\hline TANESCO & Mtwara/Lindi & TANESCO & Off-grid & Gas & 18 & 2012 & \\
\hline TANESCO & Ubungo II & TANESCO & On-grid & Gas & 105 & 2012 & \\
\hline EPP & Aggreko - Dar & Aggreko & On-grid & Oil & 70 & 2013 & \\
\hline SPP & Ngombeni & Ngombeni power Ltd & Off-grid & Biomass & 1.5 & 2013 & \\
\hline SPP & Mwenga & Mwenga hydro & On-grid & Hydro & 4 & & 2013 \\
\hline TANESCO & Mwanza & TANESCO & On-grid & Oil & 60 & 2013 & 2013 \\
\hline TANESCO & Kinyerezi I & TANESCO & On-grid & Gas & 150 & 2015 & 2014 \\
\hline IPP & Kilwa Energy & Kilwa Energy & Under development & Gas & 210 & & 2014 \\
\hline SPP & ACRA-LUMAMA & LUMAMA & Letter of intent & Hydro & 0.30 & & 2014 \\
\hline TANESCO & Kinyerezi II & TANESCO & Under development & Gas & 240 & & 2015 \\
\hline
\end{tabular}




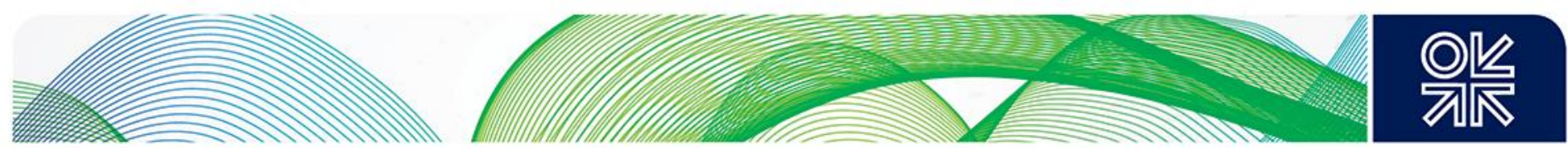

\begin{tabular}{|c|c|c|c|c|c|c|}
\hline Unknown & Mkuranga & & Tentatively planned & Gas & 250 & 2015 \\
\hline Unknown & Mufindi & & Tentatively planned & Biomass & 30 & 2015 \\
\hline Unknown & Zinga bagamoyo & & Tentatively planned & Gas & 225 & 2015 \\
\hline PPP & Geo Wind Power & TANESCO, NDC and Power Pool East Africa & Under development & Wind & 50 & 2016 \\
\hline PPP & Kinyerezi III phase 1 & TANESCO and CPI & Under development & Gas & 320 & 2016 \\
\hline SPP & Darakuta hydro & Darakuta hydro & Letter of intent & Hydro & 0.24 & 2016 \\
\hline SPP & Andoya Hydro & Andoya Hydroelectric Power Company Ltd & PPA signed & Hydro & 1 & 2016 \\
\hline SPP & Tulila & St Agnes Chipole & PPA signed & Hydro & 5 & 2016 \\
\hline Unknown & Solar I & & Tentatively planned & Solar & 60 & 2016 \\
\hline Unknown & Somanga Fungu II b & & Tentatively planned & Gas & 110 & 2016 \\
\hline PPP & Kinyerezi IV phase 1 & TANESCO and Poly Group & Under development & Gas & 330 & 2017 \\
\hline PPP & Mtwara/Lindi & TANESCO and Symbion & Under development & Gas & 600 & 2017 \\
\hline SPP & Sao Hill & Sao Hill & Letter of intent & Biomass & 10 & 2017 \\
\hline Unknown & Coastal Coal & & Tentatively planned & Coal & 300 & 2017 \\
\hline Unknown & Kiwira I & & Tentatively planned & Coal & 200 & 2017 \\
\hline Unknown & Ngaka & & Tentatively planned & Coal & 200 & 2017 \\
\hline Unknown & Wind II & & Tentatively planned & Wind & 50 & 2017 \\
\hline Unknown & Kiwira II & & Tentatively planned & Coal & 200 & 2018 \\
\hline Unknown & Mchuchuma I & & Tentatively planned & Coal & 300 & 2018 \\
\hline Unknown & Mchuchuma II & & Tentatively planned & Coal & 400 & 2018 \\
\hline Unknown & Mchuchuma III & & Tentatively planned & Coal & 400 & 2018 \\
\hline Unknown & Rusumo & & Tentatively planned & Hydro & 27 & 2018 \\
\hline Unknown & Solar II & & Tentatively planned & Solar & 60 & 2018 \\
\hline Unknown & Kakono & & Tentatively planned & Hydro & 53 & 2019 \\
\hline Unknown & Ngaka II & & Tentatively planned & Coal & 200 & 2019 \\
\hline Unknown & Malagarasi & & Tentatively planned & Hydro & 45 & 2020 \\
\hline
\end{tabular}




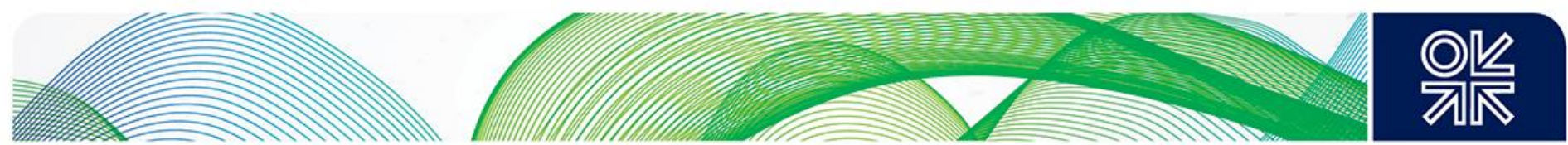

\begin{tabular}{|c|c|c|c|c|c|}
\hline Unknown & Ruhuji & Tentatively planned & Hydro & 258 & 2021 \\
\hline Unknown & Mpanga & Tentatively planned & Hydro & 144 & 2022 \\
\hline Unknown & Stiegler's Phase 1 & Tentatively planned & Hydro & 300 & 2023 \\
\hline Unknown & Rumakali & Tentatively planned & Hydro & 520 & 2025 \\
\hline SPP & Ilondo & Letter of intent & Hydro & 10.00 & \\
\hline SPP & llundo & Letter of intent & Hydro & 0.40 & \\
\hline SPP & Ilungu & Letter of intent & Hydro & 5.00 & \\
\hline SPP & Kalumbaleza & Letter of intent & Hydro & 1 & \\
\hline SPP & Kikuletwa II & Letter of intent & Hydro & 7.5 & \\
\hline SPP & Kishapu & Letter of intent & Solar & 10.00 & \\
\hline SPP & Kitewaka & Letter of intent & Hydro & 4.2 & \\
\hline SPP & KMRI - Symbion Kigoma KMRI-Symbion & Letter of intent & Biomass & 3.30 & \\
\hline SPP & KMRI-Symbion Tunduru KMRI-Symbion & Letter of intent & Biomass & 0.3 & \\
\hline SPP & Luganga & Letter of intent & Hydro & 2.80 & \\
\hline SPP & Lugarawa & Letter of intent & Hydro & 1.7 & \\
\hline SPP & Luswisi lleje & Letter of intent & Hydro & 4.70 & \\
\hline SPP & Lwega & Letter of intent & Hydro & 5 & \\
\hline SPP & Lyamanji & Letter of intent & Hydro & 2.3 & \\
\hline SPP & Mabuki & Letter of intent & Solar & 10.00 & \\
\hline SPP & Mafia & Letter of intent & Solar & 1.00 & \\
\hline SPP & Maguta & Letter of intent & Hydro & 2.50 & \\
\hline SPP & Mapembasi hydro & Letter of intent & Hydro & 10.00 & \\
\hline SPP & Matembwe & Letter of intent & Hydro & 0.5 & \\
\hline SPP & Mkumbara & Letter of intent & Biomass & 5 & \\
\hline SPP & Momba & Letter of intent & Hydro & 10.00 & \\
\hline SPP & Mpanda & Letter of intent & Solar & 1.00 & \\
\hline
\end{tabular}




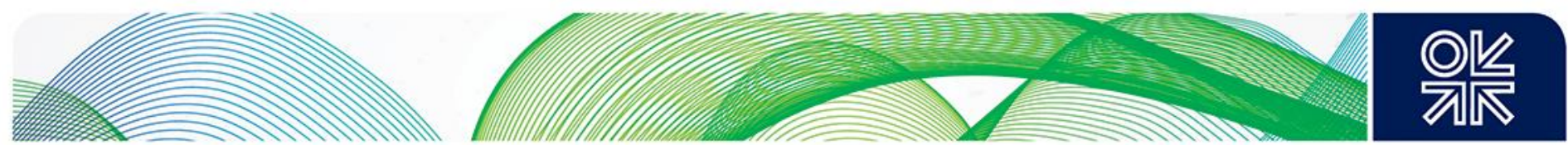

\begin{tabular}{llllll}
\hline SPP & Mpanga & Letter of intent & Hydro & 5.8 \\
\hline SPP & Nakatuta & & Letter of intent & Hydro & 10 \\
\hline SPP & NextGen Solawazi & NextGen & Letter of intent & Solar & 2 \\
\hline SPP & Nkwilo & Letter of intent & Hydro & 2.90 \\
SPP & Sumbawanga & & Letter of intent & Solar & 2.00 \\
\hline SPP & Tukuya & EA Power & Letter of intent & Hydro & 10 \\
\hline SPP & Uzia & & Letter of intent & Hydro & 1.00 \\
\hline SPP & Waste to Energy & & Letter of intent & Biomass & 5.00 \\
\hline SPP & Yovi & Letter of intent & Hydro & 2.00 \\
\hline
\end{tabular}

Table 12: List of historical and requested electricity tariffs in Tanzania (Data source: EWURA, 2012a, 2013; TANESCO, 2013)

\begin{tabular}{lllrrrrrr} 
Data & Date & Component & D1 0-75 kWh & D1 above 75 kWh & T1 & T2 & T3-MV & T3-HV \\
\hline Historical & $01 / 06 / 2006$ & Service charge (TZS/month) & 0.00 & 0.00 & 1785.00 & 6615.00 & 6615.00 & 6615.00 \\
\hline Historical & $01 / 06 / 2006$ & Energy charge (TZS/kWh) & 38.00 & 121.00 & 100.00 & 66.00 & 61.00 & 26.00 \\
\hline Historical & $01 / 06 / 2006$ & Capacity charge (TZS/kVa/month) & 0.00 & 0.00 & 0.00 & 7245.00 & 6720.00 & 3686.00 \\
\hline Historical & $01 / 02 / 2007$ & Service charge (TZS/month) & 0.00 & 0.00 & 1892.00 & 7012.00 & 7012.00 & 7012.00 \\
\hline Historical & $01 / 02 / 2007$ & Energy charge (TZS/kWh) & 40.00 & 128.00 & 106.00 & 70.00 & 65.00 & 28.00 \\
\hline Historical & $01 / 02 / 2007$ & Capacity charge (TZS/kVa/month) & 0.00 & 0.00 & 0.00 & 7680.00 & 7123.00 & 3907.00 \\
\hline Historical & $01 / 01 / 2008$ & Service charge (TZS/month) & 0.00 & 0.00 & 2303.00 & 8534.00 & 8534.00 & 8534.00 \\
\hline Historical & $01 / 01 / 2008$ & Energy charge (TZS/kWh) & 49.00 & 156.00 & 129.00 & 85.00 & 79.00 & 75.00 \\
\hline Historical & $01 / 01 / 2008$ & Capacity charge (TZS/kVa/month) & 0.00 & 0.00 & 0.00 & 9347.00 & 8669.00 & 4755.00 \\
\hline Historical & $01 / 01 / 2009$ & Service charge (TZS/month) & 0.00 & 0.00 & 2303.00 & 8534.00 & 8534.00 & 8534.00 \\
\hline Historical & $01 / 01 / 2009$ & Energy charge (TZS/kWh) & 49.00 & 156.00 & 129.00 & 85.00 & 79.00 & 75.00 \\
\hline Historical & $01 / 01 / 2009$ & Capacity charge (TZS/kVa/month) & 0.00 & 0.00 & 0.00 & 9347.00 & 8669.00 & 4755.00 \\
\hline Historical & $01 / 01 / 2010$ & Service charge (TZS/month) & 0.00 & 0.00 & 2303.00 & 8534.00 & 8534.00 & 8534.00 \\
\hline Historical & $01 / 01 / 2010$ & Energy charge (TZS/kWh) & 49.00 & 156.00 & 129.00 & 85.00 & 79.00 & 75.00 \\
\hline
\end{tabular}




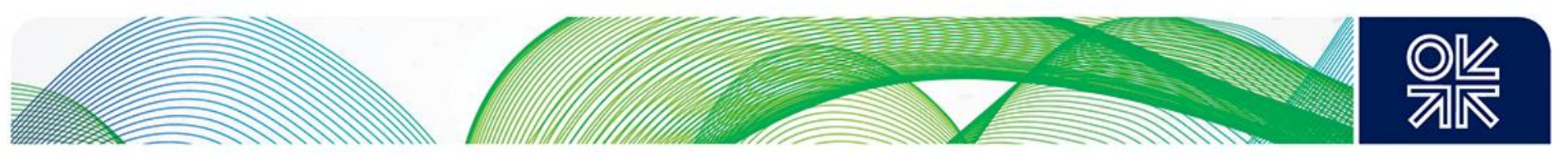

\begin{tabular}{|c|c|c|c|c|c|c|c|c|}
\hline Historical & $01 / 01 / 2010$ & Capacity charge (TZS/kVa/month) & 0.00 & 0.00 & 0.00 & 9347.00 & 8669.00 & 4755.00 \\
\hline Historical & $01 / 01 / 2011$ & Service charge (TZS/month) & 0.00 & 0.00 & 2738.00 & 10146.00 & 10146.00 & 10146.00 \\
\hline Historical & $01 / 01 / 2011$ & Energy charge (TZS/kWh) & 60.00 & 195.00 & 157.00 & 94.00 & 84.00 & 83.00 \\
\hline Historical & $01 / 01 / 2012$ & Service charge (TZS/month) & 0.00 & 0.00 & 3841.00 & 14233.00 & 14233.00 & 14233.00 \\
\hline Historical & $01 / 01 / 2012$ & Energy charge (TZS/kWh) & 60.00 & 273.00 & 221.00 & 132.00 & 79.00 & 106.00 \\
\hline Historical & $01 / 01 / 2013$ & Service charge (TZS/month) & 0.00 & 0.00 & 3841.00 & 14233.00 & 14233.00 & 14233.00 \\
\hline Historical & $01 / 01 / 2013$ & Energy charge (TZS/kWh) & 60.00 & 273.00 & 221.00 & 132.00 & 118.00 & 106.00 \\
\hline Historical & $01 / 01 / 2013$ & Capacity charge (TZS/kVa/month) & 0.00 & 0.00 & 0.00 & 16944.00 & 14520.00 & 12079.00 \\
\hline Historical & $01 / 01 / 2014$ & Service charge (TZS/month) & 0.00 & 0.00 & 5520.00 & 14233.00 & 16769.00 & 0.00 \\
\hline Proposed & $01 / 10 / 2013$ & Energy charge (TZS/kWh) & 60.00 & 467.00 & 294.00 & 252.00 & 242.00 & 179.00 \\
\hline Proposed & $01 / 10 / 2013$ & Capacity charge (TZS/kVa/month) & 0.00 & 0.00 & 0.00 & 22868.00 & 22174.00 & 17512.00 \\
\hline Historical & $01 / 01 / 2015$ & Service charge (TZS/month) & 0.00 & 0.00 & 5520.00 & 14233.00 & 16769.00 & 0.00 \\
\hline Historical & $01 / 01 / 2015$ & Energy charge (TZS/kWh) & 100.00 & 350.00 & 306.00 & 205.00 & 163.00 & 159.00 \\
\hline Historical & $01 / 01 / 2015$ & Capacity charge (TZS/kVa/month) & 0.00 & 0.00 & 0.00 & 15004.00 & 13200.00 & 16550.00 \\
\hline Proposed & $01 / 01 / 2014$ & Service charge (TZS/month) & 0.00 & 0.00 & 6506.00 & 30549.00 & 30549.00 & 30549.00 \\
\hline Proposed & $01 / 01 / 2014$ & Energy charge (TZS/kWh) & 60.00 & 506.00 & 352.00 & 277.00 & 266.00 & 186.00 \\
\hline Proposed & $01 / 01 / 2014$ & Capacity charge (TZS/kVa/month) & 0.00 & 0.00 & 0.00 & 27150.00 & 23272.00 & 18380.00 \\
\hline Proposed & $01 / 01 / 2015$ & Service charge (TZS/month) & 0.00 & 0.00 & 6613.00 & 31507.00 & 31507.00 & 31507.00 \\
\hline
\end{tabular}



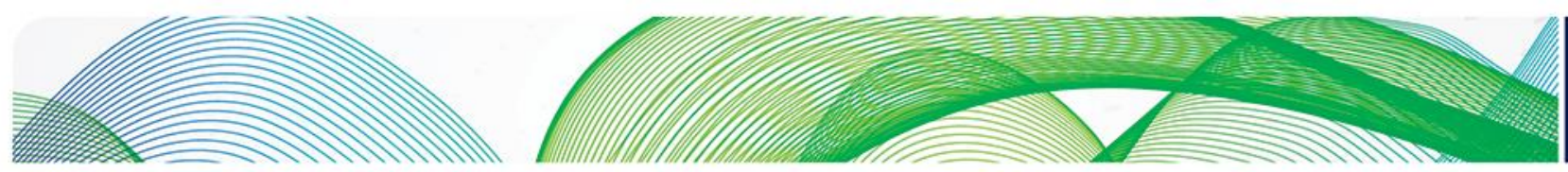

O는

\section{Appendix II: Assumptions used in the comparison of TANESCO proposal with AF-Mercados CoSS}

The cost items forecasted for the year 2013 are shown alongside their TANESCO designation and their new function segment designation in Table 13. Note that the transmission and distribution segments costs are not distinguished in the following scheme, due to lack of detailed cost breakdown, and the following assumptions have been used:

- Depreciation is attributed to the generation segment, because it is assumed that the value of generation assets is much larger than that of network assets, therefore the depreciation incurred in each year is primarily depreciation of generation assets;

- The TANESCO CIP is attributed to the network segment, assuming that the CIP consist mostly of transmission and distribution investment;

- It is assumed that the 'own generation cost' item include the operating expenses that is attributable to the generation segment, therefore all staff cost and other expenses are attributed to the network segment;

- Finally, because the CoSS counts network renewal as capital expenditure, repairs and maintenance (R\&M) is counted as T\&D CAPEX instead of OPEX.

The comparison below should be read with the limitations of these assumptions in mind, rather than being taken as absolute and definitive.

Table 13: Assignment functional segment for TANESCO revenue requirement items

\begin{tabular}{llll}
\hline \multirow{2}{*}{ Function segment } & Item & TANESCO category & Billion TZS \\
\hline & Depreciation & Depreciation & -86.2 \\
\cline { 2 - 4 } & EPP & Operating expenses & -406.9 \\
\cline { 2 - 4 } & Own generation cost & Operating expenses & -301.6 \\
\cline { 2 - 4 } T\&D CAPEX & Purchased electricity & Operating expenses & -398.6 \\
\hline \multirow{2}{*}{ T\&D OPEX } & Investment & TANESCO CIP & -434.8 \\
\cline { 2 - 4 } & R\&M & Operating expenses & -44.8 \\
\cline { 2 - 4 } & Other expenses & Operating expenses & -83.5 \\
\cline { 2 - 4 } & Provision for doubtful debts & Operating expenses & -16.8 \\
\hline \multirow{2}{*}{ Other revenue } & Staff & Operating expenses & -158.2 \\
\cline { 2 - 4 } & Government subsidy & Revenue from other sources & 136.6 \\
\cline { 2 - 4 } & Late payment penalty collection & Revenue from other sources & 19.6 \\
\cline { 2 - 4 } & Other income & Revenue from other sources & 28.4 \\
\hline \multirow{2}{*}{ Loan repayment } & Loan repayment & Financial costs & -92.4 \\
\cline { 2 - 4 } & Long outstanding creditors & Financial costs & 0 \\
\hline
\end{tabular}



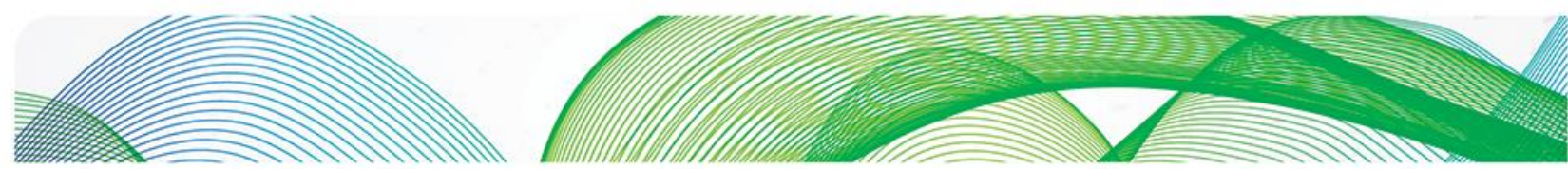

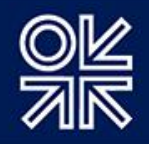

\section{Appendix III: Assumptions to derive revenue requirement based on tariff levels}

Different classes of TANESCO customers contribute to demand growth unequally. Only T1 experiences a share in the number of customers which is aligned with its share in total demand (53 per cent of total number of customers and 40 per cent of total demand). On one end, D1 < 50kWh class customers represent 22 per cent of all customers, but only 3 per cent of total demand; on the other end, T3-MV class customers represent 0.04 per cent of customers, but 33 per cent of total demand. Supposing that all customer classes contract capacity so that their maximum load factor is 0.7 (the historic system load factor), then their relative contribution to peak demand is the same as the share of demand.

Figure 59: Demand forecast for different class of customers (Data source: TANESCO, 2013)

Year

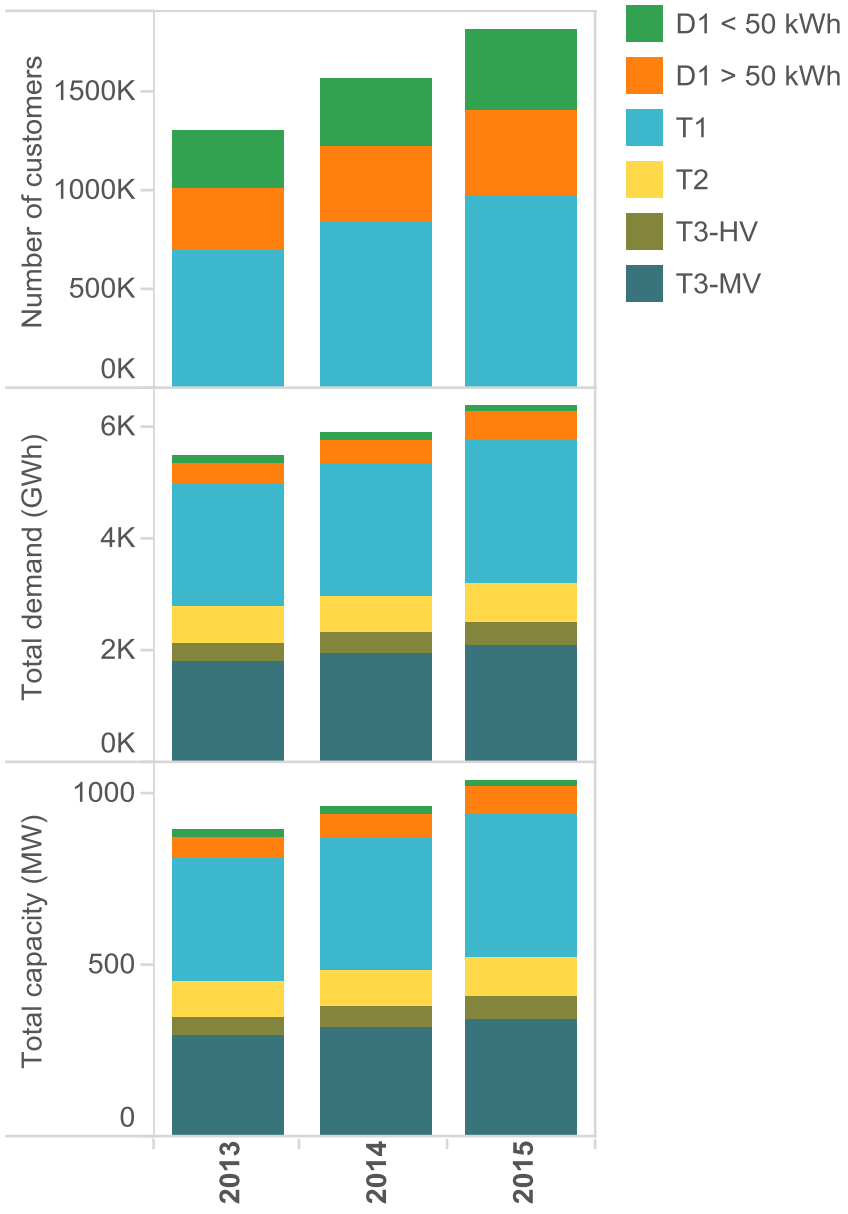

The tariff applicable to each class of customer is multiplied by the profile of the average customer (average energy consumption and average load factor of 0.7 ) in each class to obtain the average bill. The total tariff collected annually is obtained by summing the average bills calculated over the number of customers in each class and multiplying by 12 months. The amount collected is then compared with the revenue requirement proposed by TANESCO. 
Table 14: Tariff collection estimation based on average customer profiles (Own analysis based on data from TANESCO, 2013)

\begin{tabular}{|c|c|c|c|c|c|c|}
\hline Year & Category & $\begin{array}{l}\text { Avg demand } \\
\text { (kWh/month) }\end{array}$ & $\begin{array}{l}\text { Avg capacity } \\
(\mathrm{kW})\end{array}$ & $\begin{array}{l}\text { Avg bill } \\
\text { (TZS/month) }\end{array}$ & Number of customers & $\begin{array}{l}\text { Total charged annually } \\
\text { (Billion TZS) }\end{array}$ \\
\hline \multirow[t]{6}{*}{2013} & $\mathrm{D} 1<50 \mathrm{kWh}$ & 50 & 0 & 3,000 & 292,037 & 11 \\
\hline & $\mathrm{D} 1>50 \mathrm{kWh}$ & 91 & 0 & 21,953 & 312,581 & 82 \\
\hline & $\mathrm{T} 1$ & 263 & 1 & 83,013 & 699,287 & 697 \\
\hline & $\mathrm{T} 2$ & 21,278 & 42 & $6,341,535$ & 2,483 & 189 \\
\hline & T3-HV & $28,500,000$ & 55,773 & $6,078,223,923$ & 1 & 73 \\
\hline & T3-MV & 326,103 & 638 & $93,094,784$ & 461 & 515 \\
\hline \multirow[t]{6}{*}{2014} & $\mathrm{D} 1<50 \mathrm{kWh}$ & $32^{31}$ & 0 & 1,920 & 347,521 & 8 \\
\hline & $\mathrm{D} 1>50 \mathrm{kWh}$ & 91 & 0 & 23,820 & 382,678 & 109 \\
\hline & $\mathrm{T} 1$ & 237 & 0 & 89,838 & 832,145 & 897 \\
\hline & $\mathrm{T} 2$ & 19,177 & 38 & $6,361,321$ & 2,955 & 226 \\
\hline & T3-HV & $30,583,333$ & 59,850 & $6,788,572,950$ & 1 & 81 \\
\hline & T3-MV & 293,716 & 575 & $91,535,393$ & 549 & 603 \\
\hline \multirow[t]{6}{*}{2015} & $\mathrm{D} 1<50 \mathrm{kWh}$ & 22 & 0 & 1,540 & 403,005 & 7 \\
\hline & $\mathrm{D} 1>50 \mathrm{kWh}$ & 92 & 0 & 26,754 & 443,776 & 142 \\
\hline & $\mathrm{T} 1$ & 220 & 0 & 92,815 & 965,004 & 1,075 \\
\hline & $\mathrm{T} 2$ & 17,873 & 35 & $6,487,636$ & 3,427 & 267 \\
\hline & T3-HV & $33,083,333$ & 64,742 & $7,977,258,350$ & 1 & 96 \\
\hline & T3-MV & 273,847 & 536 & $92,410,644$ & 636 & 705 \\
\hline
\end{tabular}

31 TANESCO only provided demand estimates for D1 as a whole, so the disaggregation into the two separate classes is based on the authors' discretion. Average demand for D1 < 50 kWh customers is assumed to decrease over time due to the aggressive addition of newly electrified customers in this category, while average demand in the D1 $>50 \mathrm{kWh}$ category is assumed to remain constant over time. 

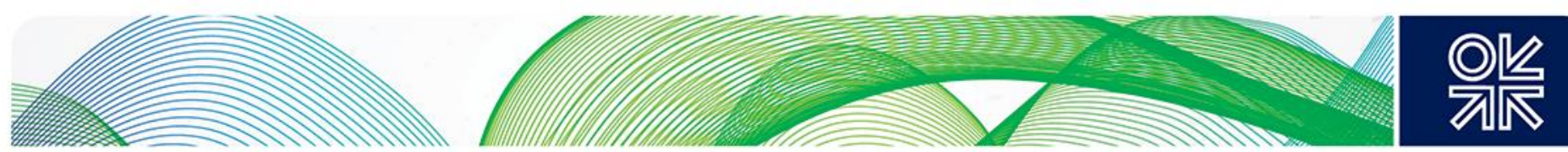

\section{References}

ADB. (2013). Bangladesh: Tariff Reform and Inter-sectoral Allocation of Natural Gas. Asian Development Bank Technical Assistance Final Report.

AF-Mercados. (2013). Cost of Service Study Final Report.

Aggreko. (2015a). Reasons to invest in Aggreko. Retrieved January 1, 2015, from http://ir.aggreko.com/investors/investment-case.aspx

Aggreko. (2015b, January 26). Aggreko extends 200 MW Ivory Coast power project. Abidjan. Retrieved from http://www.aggreko.com/media-centre/press-releases/aggreko-extends-200mw-ivory-coastpower-project/

Ahlborg, H., \& Hammar, L. (2014). Drivers and barriers to rural electrification in Tanzania and Mozambique - Grid-extension, off-grid, and renewable energy technologies. Renewable Energy, 61, 117-124. doi:10.1016/j.renene.2012.09.057

Ahlborg, H., \& Sjöstedt, M. (2015). Small-scale hydropower in Africa: Socio-technical designs for renewable energy in Tanzanian villages. Energy Research \& Social Science, 5, 20-33. doi:10.1016/j.erss.2014.12.017

ANARE. (2013). Rapport d'activités.

BBC. (2016). Ivory Coast Country Profile. Retrieved February 25, 2016, from http://www.bbc.co.uk/news/world-africa-13287216

BBC News. (2008, February 7). Tanzanian PM to resign over graft. Retrieved from http://news.bbc.co.uk/1/hi/world/africa/7232141.stm

Bloomberg. (2015, May). Shell to Add Firepower to BG Assets in East Africa LNG Race. Retrieved from http://www.bloomberg.com/news/articles/2015-05-12/shell-to-add-firepower-to-bg-assets-ineast-africa-Ing-race

BPDB. (2014). Annual Report 2013-2014. Bangladesh Power Development Board. Retrieved from http://www.bpdb.gov.bd/download/annual_report/Annual Report 2013-2014.pdf

BPDB. (2015a). Commercial: Tariff Description. Retrieved December 20, 2015, from http://www.bpdb.gov.bd/bpdb/index.php?option=com_content\&view=article\&id=35\&ltemid=125

BPDB. (2015b). Key Statistics: Present Installed Generation Capacity (MW) as on September, 2015. Retrieved December 19, 2015, from http://www.bpdb.gov.bd/bpdb/index.php?option=com_content\&view=article\&id=5\&ltemid=6

Bukurura, S. H. (2015). Commercialisation of Natural Gas in Tanzania: Are there any lessons fro the Songo Songo Gas to Power Project. 20th REPOA Annual Research Worksho[. Retrieved from http://www.repoa.or.tz/documents_storage/20ARWS1E_PPT.pdf

Castellano, A., Kendall, A., Nikomarov, M., \& Swemmer, T. (2015). Brighter Africa: The growth potential of the sub-Saharan electricity sector. McKinsey\&Company. Retrieved from http://www.mckinsey.com/ /media/mckinsey/dotcom/insights/energy resources materials/powering africa/brighter_africa_the_growth_potential_of_the_subsaharan_electricity_sector.ashx

Chinonso, T. (2015, March 14). Côte d'Ivoire seeks LNG supply from Nigeria. The Vanguard. Retrieved from http://www.vanguardngr.com/2015/03/cote-divoire-seeks-Ing-supply-from-nigeria/ 

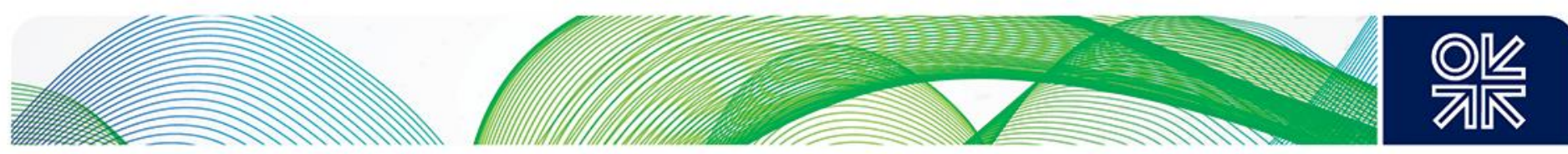

Clyde\&Co. (2015). Tanzania Bill establishing the Petroleum Act 2015. Retrieved September 28, 2015, from http://www.clydeco.com/uploads/Files/CC007807_Clyde_Co_Tanzania_22-06-

15_final_(2).pdf

Daily News Reporters. (2015, December 3). Negotiations underway to check Songas switch-off. Daily News. Dar es Salaam. Retrieved from http://www.dailynews.co.tz/index.php/home-news/44732negotiations-underway-to-check-songas-switch-off

DESCO. (2014). Annual Report 2014. Dhaka Electric Supply Company Limited. Retrieved from https://www.desco.org.bd/uploads/attachments/ann_report_14-15.pdf

Diu, J. B. (2011). Determinants of Residential Demand for Electricity in Tanzania (1974-2009). The Open University of Tanzania.

DPDC. (2014). Annual report 2014. Dhaka Power Distribution Company Limited. Retrieved from https://www.dpdc.org.bd/assets/ar/anl_rpt13_14.pdf

Economic and Social Research Foundation. (2009). Petroleum Exploration Study: A Baseline Survey Report. The Norwegian People's Aid. Retrieved from http://www.policyforumtz.org/files/ESRFNPAPetroleumSectorBaselineReport.pdf

EIA. (2014). Mozambique: International energy data and analysis. Retrieved September 29, 2015, from http://www.eia.gov/beta/international/analysis.cfm?iso=MOZ

ESI Africa. (2015). Gas to power: Texan IPP to develop 375 MW project in Côte d'lvoire. Retrieved February 25, 2016, from http://www.esi-africa.com/news/gas-to-power-texan-ipp-to-develop375mw-project-in-cote-divoire/

EWURA. (2009). Tariff Application Guidelines for 2009. Energy and Water Utilities Regulatory Authority. Retrieved from http://www.ewura.com/newsite/attachments/acts/Tariff Application Guidelines 2009.pdf

EWURA. (2012a). Determination of Mult-Year Cost Reflective Electricity Tarifss in Tanzania. EWURA Discussion paper.

EWURA. (2012b). Licensable Activities - EWURA. Retrieved September 28, 2015, from http://www.ewura.go.tz/newsite/index.php/2012-03-07-08-18-59/licensing-work/10-licensingarticles/21-licensable-activities

EWURA. (2013). The Tanzania Electric Supply Company Multi-Year Tariff Adjustment Order, 2013.

EWURA. (2014). The Tanzania Electric Supply Company (Tariff Adjustment) (Amendment) Order, 2014. Retrieved from http://144.76.33.232/wp-content/uploads/2015/03/2014-028-TANESCOTariff-Adjustment-1ST-2ND-Quarter-ENGLISH.pdf

Gas Strategies. (2014). Long is the way that leds up to Tanzania LNG. Retrieved from http://web.gasstrategies.com/sites/default/files/gsis_tanzania_Ing_oct_2014.pdf

Ghanadan, R. (2009). Connected geographies and struggles over access: Electricity commercialisation in Tanzania. In Electric Capitalism: Recolonising Africa on the Power Grid. Cape Town: Earthscan.

Globeleq. (2015, July 1). Globeleq celebrates completion of the Azito power plant expansion in Côte d'Ivoire. London. Retrieved from http://www.globeleq.com/news/press_release/98/Globeleqcelebrates-completion-of-the-Azito-power-plant-expansion-in-Cte-dlvoire

Gomes, I. (2013). Natural Gas in Pakistan and Bangladesh: current issues and trends. Oxford Institute for Energy Studies Working Paper. Retrieved from http://www.oxfordenergy.org/wpcms/wpcontent/uploads/2013/06/NG-77.pdf 

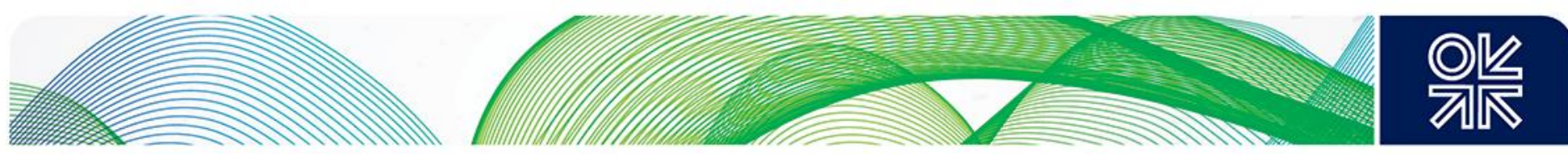

Gratwick, K., Ghanadan, R., \& Eberhard, A. (2007). Generating Power and Controversy: Understanding Tanzania's Independent Power Projects. Management Programme in Infrastructure Reform \& Regulation Working Paper: Full version.

Gray, H. (2015). The political economy of grand corruption in Tanzania. African Affairs, 114(456), 382403.

Greacen, C. (2014). Mini-grid systems on the rise in Tanzania Status of implementation and regulatory framework conditions. In Workshop Mini-Grid Systems: Reducing risks and costs through the anchor customer business model. Retrieved from https://www.giz.de/fachexpertise/downloads/2014-en-greacen-pep-fachworkshop-mini-grids.pdf

Hanauer, L., \& Morris, L. J. (2014). Chinese Engagement in Africa: Drivers, Reactions, and Implications for U.S. Policy. International Security and Defense Policy Center of the RAND National Defense Research Institute.

IAEA. (2013). Bangladesh. Retrieved December 20, 2015, from http://wwwpub.iaea.org/MTCD/Publications/PDF/CNPP2013_CD/countryprofiles/Bangladesh/Bangladesh.h tm

IEA. (2013). United Republic of Tanzania. Retrieved December 15, 2015, from http://www.iea.org/sankey/\#?c=United Republic of Tanzania\&s=Final consumption

IFC. (2013). Ciprel Power, Cote d'lvoire. Retrieved February 25, 2016, from http://www.ifc.org/wps/wcm/connect/industry_ext_content/ifc_external_corporate_site/industries/i nfrastructure/power/ciprel+power,+cote+divoire

IMF. (2012). Côte d'Ivoire: First Review Under the Three-Year Arrangement Under the Extended Credit Facility, Request for Modification of Performance Criteria, and Financing Assurances Review; Press Release. Retrieved from https://www.imf.org/external/pubs/ft/scr/2012/cr12117.pdf

IMF. (2013). Bangladesh: Poverty Reduction Strategy Paper. Wahington D.C.: IMF Country Report. Retrieved from https://www.imf.org/external/pubs/ft/scr/2013/cr1363.pdf

Innovation Energie Developpement. (2014). National Electrification Program Prospectus. Retrieved from http://www.ied-sa.fr/index.php/en/documents-and-links/publications/category/3-reports.html

Janus, H., \& Keijzer, N. (2015). Big Results Now? Emerging Lessons from Results-Based Aid in Tanzania. Germain Development Institute Discussion Paper. Retrieved from https://www.diegdi.de/uploads/media/DP_4.2015.pdf

Kabendera, E., \& Anderson, M. (2014, December 24). Tanzania energy scandal ousts senior politicians. The Guardian. Dar es Salaam. Retrieved from http://www.theguardian.com/globaldevelopment/2014/dec/24/tanzania-energy-scandal-ousts-senior-politicians

Kahyoza, N., \& Greacen, C. (2011). Tanzania's Experience in Establishing a Regulatory System for Promoting Grid and Off-Grid Small Power Producers (SPPs). Dakar: African Electrification Initiative Workshop.

Kapika, J., \& Eberhard, A. (Eds.). (2013). Tanzania: Learning the hard way. In Power-Sector Reform and Regulation in Africa: Lessons from Kenya, Tanzania, Uganda, Zambia, Namibia and Ghana.

Kichonge, B., John, G. R., Mkilaha, I. S. N., \& Hameer, S. (2014). Modelling of Future Energy Demand for Tanzania. Journal of Energy Technologies and Policy, 4(7), 16-32.

Kihwele, S., Hur, K., \& Kyaruzi, A. (2012). Visions, Scenarios and Action Plans Towards Next Generation Tanzania Power System. Energies, 5(12), 3908-3927. doi:10.3390/en5103908

Lazimah, J. (2014). Energy Sector Initiatives in Tanzania. The Low Carbon Development Worhkshop 22-23 January 2014. Retrieved from http://www.fessustainability.org/sites/default/files/u43/lazimah.pdf 

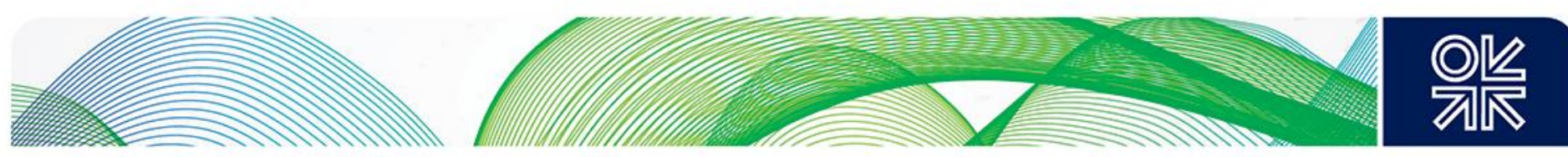

Ledesma, D. (2013). East Africa Gas - Potential for Export. Oxford Institute for Energy Studies Working Paper.

Luhwago, R. (2011, August 14). Govt unveils Sh523b power rescue plan. The Guardian. Retrieved from http://www.ippmedia.com/frontend/index.php?l=32222

Malgas, I., \& Gratwick, K. (2008). Through the Fire: Independent Power Projects and Power Sector Reform in Côte d'Ivoire. Cape Town: MIR Working Paper.

Manson, K. (2014, November 4). Tanzania natural gas investment threatened by arrest of officials. Financial Times. Nairobi. Retrieved from http://www.ft.com/cms/s/0/b789caaa-6431-11e4-bac800144feabdc0.html\#axzz3n4BnzvjJ

Masih, I., Maskey, S., Mussá, F. E. F., \& Trambauer, P. (2014). A review of droughts on the African continent: a geospatial and long-term perspective. Hydrology and Earth System Sciences, 18(9), 3635-3649. doi:10.5194/hess-18-3635-2014

MEM. (2014). Electricity Supply Industry Reform Strategy and Roadmap 2014-2025. Ministry of Energy and Minerals. Retrieved from http://www.gst.go.tz/images/TANZANIA ELECTRICITY SUPPLY INDUSTRY REFORM STRATEGY \& ROADMAP.pdf

Ministry of Energy and Minerals. (2012). Power System Master Plan 2012 Update. United Republic of Tanzania.

Ministry of Energy and Minerals. (2013a). Power System Master Plan 2012 Update. Retrieved from http://www.tanesco.co.tz/index.php?option=com_docman\&task=doc_download\&gid=68\&ltemid= 172

Ministry of Energy and Minerals. (2013b). The National Natural Gas Policy of Tanzania - 2013. Retrieved from http://www.tanzania.go.tz/egov_uploads/documents/Natural_Gas_Policy__Approved_sw.pdf

Ministry of Petroleum and Energy. (2012). Plan d'actions et d'investissements en electrification rurale. Retrieved from http://www.anare.ci/assets/files/pdf/documents/atel-semin/4MMPE-SNE2012Rapport-Com3-Electrification-Rurale.pdf

Ministry of Petroleum and Energy. (2015). Opportunities and Challenges in the Oil and Gas Sectors in Côte d'Ivoire. New Delhi: 4th India-Africa Hydrocarbons Conference. Retrieved from http://www.iahc2016.com/Cote-D-Ivoire.pdf

Mtepa, M. (2014). Tanzania Case Study: Achievements and Challenges. Banjul: The 3rd Gambia National Forum: Policy on Small Scale Renewable Energy Regulation.

Mujeri, M. K., \& Chowdhury, T. T. (2013). Quick Rental Power Plants in Bangladesh: An Economic Appraisal. Bangaldesh Institute of Development Studies. Retrieved from http://bids.org.bd/publication/dpaper/discussion_paper_01.pdf

Munasinghe, M. (1981). Principles of modern electricity pricing. Proceedings of the IEEE. doi:10.1109/PROC.1981.11970

Murshid, K. A. S., \& Wiig, A. (2001). A review of development trends in the energy sector of Bangladesh. Chr. Michelsen Institute Report. Retrieved from http://www.cmi.no/publications/file/958-a-reviewof-development-trends-in-the-energy.pdf

Mwamunyange, J. (2013a, April 6). Court deals TANESCO huge blow, orders firm to pay up $\$ 77.5$ million. The East African. Retrieved from http://www.theeastafrican.co.ke/news/Court-ordersTanesco-to-pay-up-USD77-million-/-/2558/1741356/-/dkc7dy/-/index.html

Mwamunyange, J. (2013b, July 20). TANESCO probe reveals massive power theft. The East African. Retrieved from http://www.theeastafrican.co.ke/news/Tanesco-probe-reveals-massive-powertheft/-/2558/1920942/-/d5flthz/-/index.html 

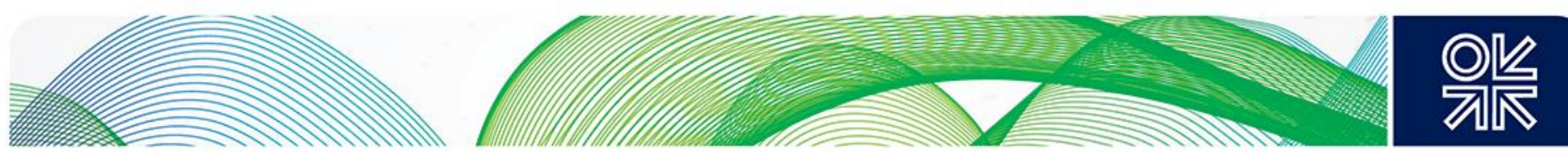

Ng'wanakilala, F. (2014, November 13). Tanzania says LNG project could cost up to $\$ 30$ bln. Reuters. Dar es Salaam. Retrieved from http://af.reuters.com/article/investingNews/idAFKCNOIX1OD20141113

Ng'wanakilala, F. (2015, June 7). Tanzania lifts gas resources estimate to 55 trillion cubic feet. Dar es Salaam. Retrieved from http://af.reuters.com/article/tanzaniaNews/idAFL5NOYTONO20150607

Ngamlagosi, F. (2012). Electricity Pricing in Tanzania. East African Power Industry Convention Presentation. Retrieved from http://www.esi-africa.com/wpcontent/uploads/Felix_Ngamlagosi.pdf

Ngamlagosi, F. (2015). Policy, PPA Framework and Need for Reliable Off-Takers in Tanzania. Nairobi: Presentation at the 17th East Africa Power Industry Convention.

NKRA Energy. (2015). National Key Result Area Energy 2013/14-2015/16. Tanzania Development Vision 2025 Big Results Now! Roadmap.

Norton Rose Fulbright. (2014a). A snapshot of Tanzanian natural gas. Retrieved September 30, 2015,

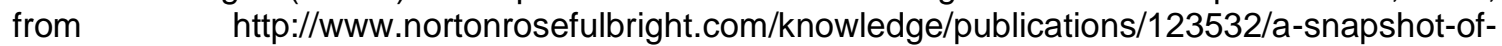
tanzanian-natural-gas

Norton Rose Fulbright. (2014b). Tanzania natural gas policy. Retrieved September 28, 2015, from http://www.nortonrosefulbright.com/knowledge/publications/110979/tanzania-natural-gas-policy

Orca Exploration Group Inc. (2015). 2014 Annual Report. Retrieved from http://www.orcaexploration.com/pdfs/2014_OrcaExploration_AR_FULL.pdf

Parmesano, H., Rankin, W., Nieto, A., \& Irastorza, V. (2004). Classification and Allocation Methods for Generation and Transmission in Cost-of-Service Studies. Los Angeles.

Pedersen, R. H., \& Bofin, P. (2015). The politics of gas contract negotiations in Tanzania: a review. DIIS Working Paper 2015.

REB. (2015). Rural Electrification Programme at a Glance. Retrieved December 20, 2015, from http://www.reb.gov.bd/index.php/abreb/stat

Reneses, J., Rodríguez, M. P., \& Pérez-Arriaga, I. J. (2013). Electricity Tariffs. In Regulation of the Power Sector. Springer.

Reuters. (2013, January 9). Ivory Coast signs $\$ 500$ mln loan deal with China's Exim. Retrieved from http://www.reuters.com/article/ivorycoast-china-power-idUSL5E9C9CPS20130109

Reuters. (2014, September 24). Ivory Coast's Foxtrot aims to secure gas output for next decade. Retrieved from http://www.reuters.com/article/ivorycoast-natgas-foxtrotidUSL6N0RP4XL20140924

Rigzone Staff. (2015, August 21). Mnazi Bay Gas Wells Deliver 1st Gas to Tanzania Pipeline. Retrieved from

http://www.rigzone.com/news/oil_gas/a/140236/Mnazi_Bay_Gas_Wells_Deliver_1st_Gas_to_Ta nzania_Pipeline

Shih, T. H. (2013). China to provide Africa with US\$1tr financing. South China Morning Post. Retrieved from http://www.scmp.com/business/banking-finance/article/1358902/china-provide-africa-us1trfinancing

Sieh, R. D. (2015, September 28). Liberia: Low Cost Electricity, High Expectations - CLSG Chief Speaks. Front Page Africa. Monrovia. Retrieved from http://allafrica.com/stories/201509281927.html

Simbeye, F. W. (2015, March 3). Orca Plans 221 bn - Songo Songo Expansion. Tanzania Daily News. Dar es Salaam. Retrieved from http://allafrica.com/stories/201503031189.html 

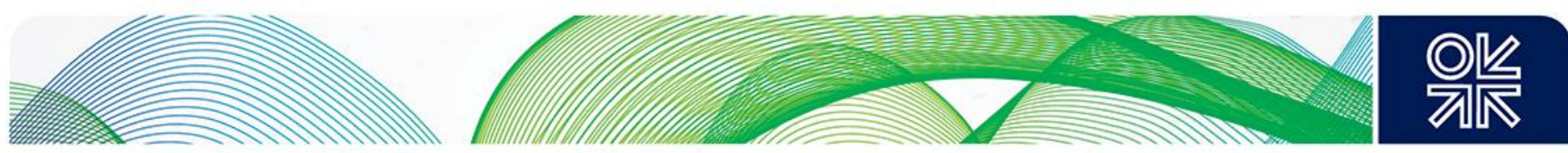

Straeten, J. van der. (2015). Electrification in Tanzania from a Historical Perspective - Discourses of Development and the Marginalization of the Rural Poor. In Micro Perspectives for Decentralized Energy Supply (Martina Sc.). Proceedings of the International Conference.

Sun, Y. (2014). China's Aid to Africa: Monster or Messiah. The Brookings Institution. Retrieved from http://www.scmp.com/business/banking-finance/article/1358902/china-provide-africa-us1trfinancing

Sunday News Reporter. (2015, October 4). VIP seeks to recover $1 \mathrm{tr} /$ - over delay to convert plant. Daily News. Dar es Salaam. Retrieved from http://www.dailynews.co.tz/index.php/features/42798-vipseeks-to-recover-1tr-over-delay-to-convert-plant

Sy, A. (2015). Are African countries rebasing GDP in 2014 finding evidence of structural transformation? Brookings. Retrieved from http://www.brookings.edu/blogs/africa-in-focus/posts/2015/03/04african-gdp-structural-transformation-sy-copley

Symbion Power. (2015). Symbion power capabilities Generation. Retrieved September 28, 2015, from http://symbion-power.com/capabilities/power-plants/

TANESCO. (2013). TANESCO Tariff Review Application. Tanzania Electric Supply Company Ltd.

Tenenbaum, B., Greacen, C., Siyambalapitiya, T., \& Knuckles, J. (2014). Introduction. In From the Bottom Up: How Small Power Producers and Mini-Grids Can Deliver Electrification and Renewable Energy in Africa. The World Bank.

The Business Year. (2014). High-Tech Show. Retrieved September 29, 2015, from https://www.thebusinessyear.com/tanzania-2014/high-tech-show/interview

The Citizen Investigative Team. (2014, March 3). \$210m deal: Story of IPTL, PAP and High Court. Retrieved from http://www.thecitizen.co.tz/News/-270m-deal--Story-of-IPTL--PAP-and-HighCourt/-/1840392/2228606/-/1bddmgz/-/index.html

The Economist. (2014, September). Sharing the spoils: Tanzania's troubles over gas revenue. The Economist. Retrieved from http://www.economist.com/blogs/baobab/2014/09/tanzanias-troublesover-gas-revenue

The United Republic of Tanzania Ministry of Finance. (2014). The State of the National Economy in 2013 (in Swahili). Retrieved from http://www.mof.go.tz/mofdocs/macroeconomic/TAARIFA YA HALI YA UCHUMI WA TAIFA KATIKA MWAKA 2013.pdf

The World Bank. (2014). Project information document concept stage. Retrieved from http://wwwwds.worldbank.org/external/default/WDSContentServer/WDSP/SAR/2014/07/23/090224b0825b 02e3/1_0/Rendered/PDF/ProjectOInform0nt0Project000P128012.pdf

Tomnay, N. (2015). Where are all the LNG project postponements? Retrieved September 29, 2015, from http://blogs.woodmac.com/where-are-all-the-Ing-project-postponements/

Traoré, A. (2013). Independent power generation: the Ivoirian model. Retrieved from http://www.proparco.fr/webdav/site/proparco/shared/PORTAILS/Secteur_prive_developpement/ PDF/SPD18/SPD18_Amidou_traore_UK.pdf

Tsakhara, P. (2015). Presentation on the Tanzanian Solar PV-Hybrid Workshop Held in Berlin, Germany. TANESCO. Retrieved from https://www.giz.de/fachexpertise/downloads/2015-tanescopresentation-tansania.pdf

Vagliasindi, M., \& Besant-Jones, J. (2013). Tanzania. In Power Market Structure: Revisiting Policy Options. The World Bank.

Wentworth Resources Limited. (2015a). Corporate Presentation March 2015. Retrieved from http://www.wentworthresources.com/pdf/Wentworth-Corporate-Presentation-March-2015-

Final.pdf 

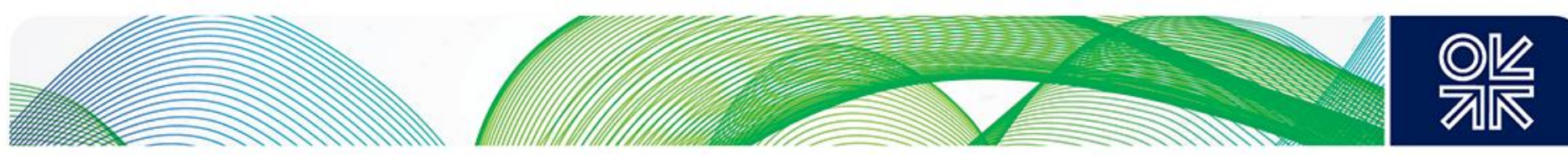

Wentworth Resources Limited. (2015b). Corporate Presentation October 2015. Retrieved from http://www.wentworthresources.com/pdf/Wentworth-Corporate-Presentation-October-2015FINAL.pdf

Wentworth Resources Limited. (2015c). Large-Scale Gas Monetization Projects. Retrieved September 29, 2015, from http://www.wentworthresources.com/large-scale.php

White \&Case LLP. (2011). Portfolio Gas Supply Grrement between TPDC, PanAfrican Energy Tanzania LImited, and TANESCO. Retrieved from http://panafricanenergy.com/pdfs/Portfolio-GasAgreement-17_June_2011.pdf

Wood Mackenzie. (2015). Unlocking East Africa's upstream potential. Retrieved September 29, 2015, from http://www.woodmac.com/analysis/east-africa-upstream

Yescombe, E. R. (2007). Public-Private Partnerships: Principles of Policy and Finance. London: Elsevier Ltd. 